UNIVERSIDADE DE SÃO PAULO

INSTITUTO DE GEOCIENCIAS

\title{
APLICAÇÃO DE GEOPROCESSAMENTO NA ANÁLISE DE FAVORABILIDADE PARA MINERALIZAÇÕES DE CHUMBO, ZINCO E COBRE NAS FOLHAS CERRO AZUL E APIAÍ, VALE DO RIBEIRA, (SP E PR)
}

CARLOS CÉSAR DE ARAÚJO

Orientador: Prof. Dr. Arlei Benedito Macedo

DISSERTAÇÃO DE MESTRADO

COMISSÃO JULGADORA

Nome

Presidente

Prof. Dr. Arlei Benedito Macedo

Examinadores: Prof. Dr. Elias Carneiro Daitx

Prof. Dr. Sidnei Pires Rostirolla

Assinatura

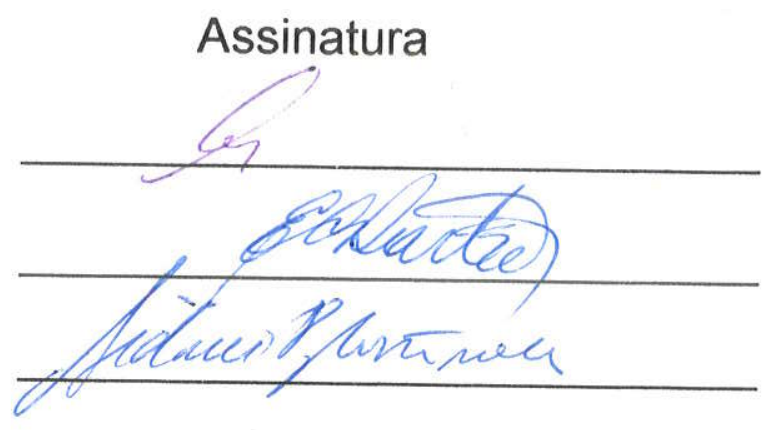



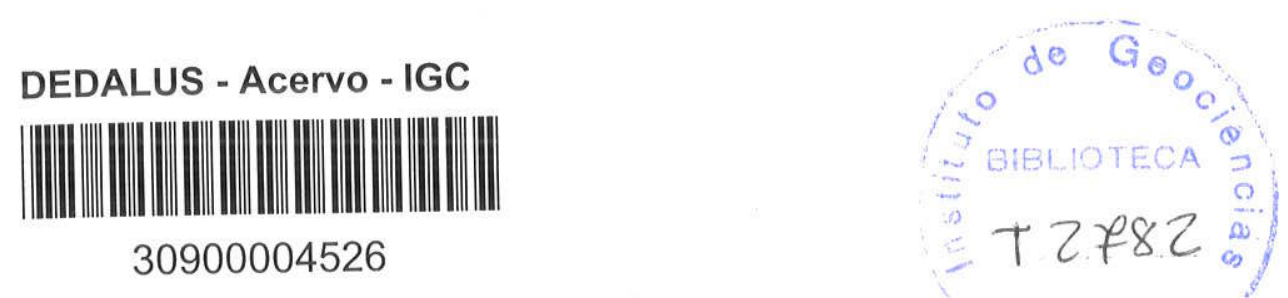

APLICAÇÃO DE GEOPROCESSAMENTO NA ANÁLISE DE FAVORABILIDADE PARA MINERALIZAÇÕES DE CHUMBO, ZINCO E COBRE NAS FOLHAS CERRO AZUL E APIAÍ, VALE DO RIBEIRA, (SP E PR).

Carlos César de Araújo

Orientador: Prof. Dr. Arlei Benedito Macedo

DISSERTAÇÃO DE MESTRADO

Programa de Pós-graduação em Recursos Minerais e Hidrogeologia 
A Orbélia, minha mãe. Ao Marcos, meu irmão e amigo. 


\section{Agradecimentos}

Este trabalho foi possivel somente com o apoio da Fapesp, por intermédio de bolsa de mestrado e auxílio pesquisa (processos 97/04664-6 e 97/04272-0).

Várias pessoas e instituições me ajudaram durante 0 período de desenvolvimento deste trabalho. Cito aqueles que contribuíram diretamente, se deixo de citar alguém é porque a memória me trai mas fica meu agradecimento a todos.

Agradeço ao Instituto de Geociências da USP pelo apoio institucional.

Agradeço ao professor Arlei Benedito Macedo, orientador, pelo estímulo ao trabalho, discussão dos assuntos abordados e minuciosa revisão do texto que muito ajudou para o êxito desta dissertação.

Meu agradecimento ao professor Elias Carneiro Daitx o qual contribuiu significativamente através de suas opiniões a respeito do trabalho.

Ao professor Ginaldo Adhemar da Cruz Campanha pela constante atenção e presteza nos assuntos relacionados ao projeto e pela ajuda na compilação do mapa geológico, parte essencial deste trabalho.

Do mesmo modo agradeço à CPRM pela cessão dos dados geoquímicos, de ocorrências minerais e aerogeofísicos, em especial a José Ribamar Bezerra, e a Ídio Lopes Jr. Agradeço também à Mônica Mazzini Perrotta pela revisão do texto e discussão sobre os temas de geoprocessamento, sua contribuição foi significativa ao trabalho. Agradeço à Mineropar pelos dados geoquímicos em especial ao geólogo Otávio Augusto Boni Licht. Agradeço ao Duílio Rondinelli pelas discussões a respeito de tratamento de dados geoquímicos.

Agradeço à Universidade Federal do Paraná, em especial ao professor Francisco José Fonseca Ferreira, pela orientação no tratamento dos dados aerogeofísicos. Meu agradecimento a Francisco Valdyr da Silva e a Maximilian Forlin pelo auxílio no processamento dos dados aerogeofísicos. Também agradeço à doutoranda, na Unicamp, Sílvia Rolim, pelas discussões e sugestões a respeito do tratamento dos dados aerogeofísicos.

Agradeço aos professores Jorge Kazuo Yamamoto, Jorge Silva Bettencourt e Fábio Taioli, sempre prontos a dar sua atenção e conselhos, em relação aos assuntos desta dissertação.

Agradeço ao professor Aledir Barbour a respeito das discussões sobre os modelos de mineralização.

Agradeço ao professor João Batista Moreschi pela atenção dada ao trabalho na forma de discussões acerca das mineralizações. Minha admiração ao exemplo que é, como excelente professor de geologia.

Agradeço à professora Gianna Maria Garda pelas sugestões para o abstract.

Ao aluno de iniciação científica Sérgio Nobuo Godoy Saito pelo auxílio no tratamento dos dados geoquímicos e preparação de figuras. Sua ajuda foi de grande valia no desenvolvimento do projeto.

Agradeço à amizade demonstrada pelo Hélio Shimada desde meus tempos de graduação, agora na forma de revisão atenta do texto e sugestões de artigos.

Agradeço ao colega Sérgio Luís Fabris de Matos, suas opiniões e incentivo sempre positivos ajudaram muito na tomada de decisões no trabalho. E à mestranda Márcia Mika Saito pela ajuda na montagem dos volumes 
Agradeço ao colega Alexandre Carnier Nunes da Silva pelo apoio demonstrado durante o trabalho na forma de discussões sobre geoprocessamento.

Agradeço Marcos Sousa Campos por ceder os dados geoquímicos de sua dissertação de mestrado.

Agradeço aos funcionários do departamento, João Victor Maschi e Vera Lúcia Tardelli, Priscilla Godoy e Pedro Carlos Poccioti pela ajuda sempre pronta, nos trabalhos do dia a dia.

Aos funcionários da biblioteca do Instituto de Geociências, em especial à Brenda Maria Mascarenhas e Maria Aparecida Bezerra, pelo profissionalismo e pontualidade.

A Rita Parisi Conde pela ajuda com a utilização da estação SUN. Sem esta ajuda, este trabalho não seria possivel.

Às secretárias da seção de pós-graduação Ana Paula Cabanal Pentagna e Magali Poli Fernandes Rizzo, pela solicitude para resolver o trabalho burocrático com muita simpatia e bom humor.

Agradeço à amiga Veridiana Teixeira de Souza Martins pela minuciosa e paciente revisão do texto e discussões sempre positivas a respeito do trabalho.

Agradeço ao colega Marcelo Monteiro da Rocha, pela constante ajuda e conselhos com os assuntos da dissertação não medindo esforços nem tempo.

Um especial agradecimento ao velho e bom amigo, Sérgio Vicente Liotte, companheiro de trabalho, que com seu bom senso e bom humor contribuiu não só com as discussões a respeito dos aspectos técnicos do trabalho mas também com sua amizade e presteza.

E sem dúvida agradeço aqueles que são a base da minha vida, sem eles eu não teria conseguido chegar até aqui: meu irmão, Marcos, minha mãe, Orbélia e meu pai, José. Um agradecimento especial para minha querida Vanessa, seu companheirismo e carinho foram fundamentais durante este trabalho. 


\section{Índice}

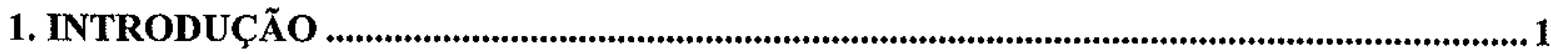

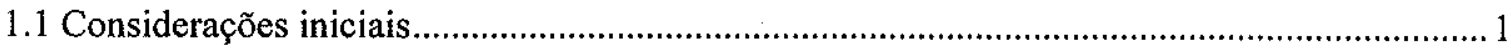

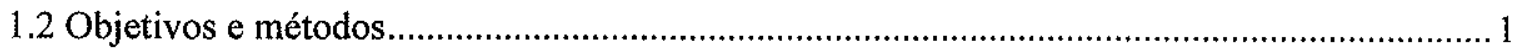

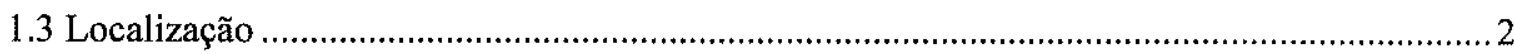

2. DADOS ANTERIORES

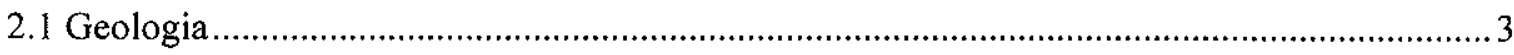

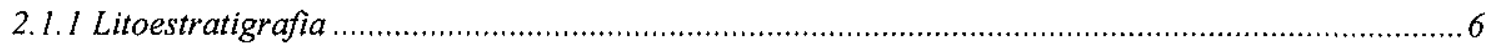

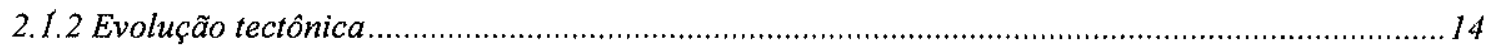

2.2 Mineralizações sulfetadas no Vale do Ribeira ................................................................. 15

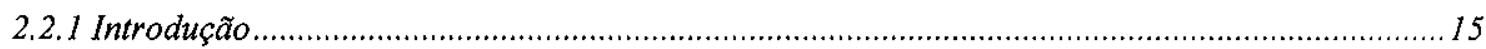

2.2.2 Tipo Perau

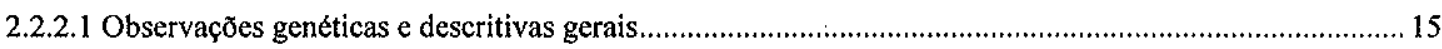

2.2.2.2 Observaçð̃es genéticas e descritivas - casos no Vale do Ribeira ......................................................18

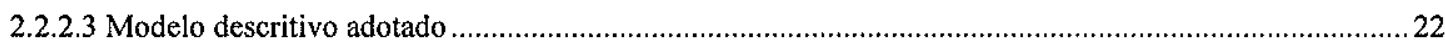

2.2.2.4 Parâmetros de prospecção para depósitos tipo Perau aplicados em geoprocessamento............................24

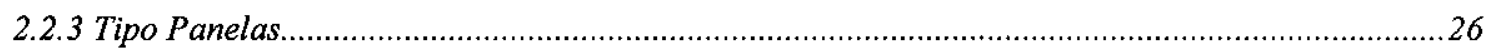

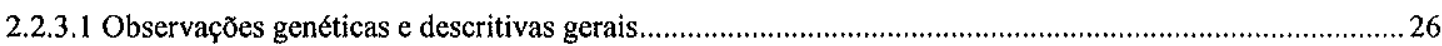

2.2.3.2 Observaçðes genéticas e descritivas - casos no Vale do Ribeira ...................................................27

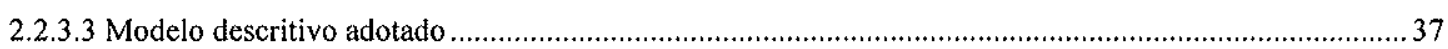

2.2.3.4 Parâmetros de prospecç̃̃o para depósitos tipo Panelas aplicados em geoprocessamento..........................39

2.3 Análise de favorabilidade por geoprocessamento - casos de aplicação .................................... 41

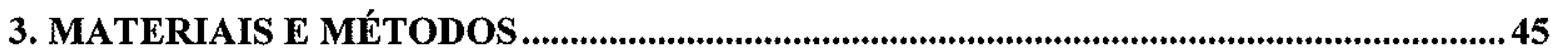

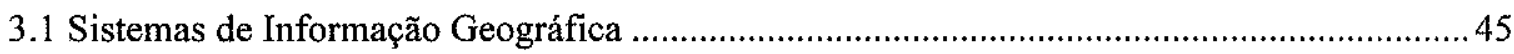

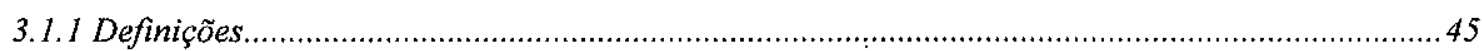

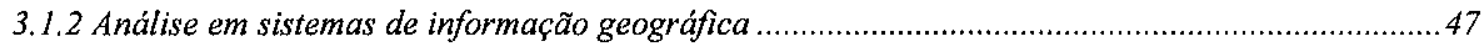

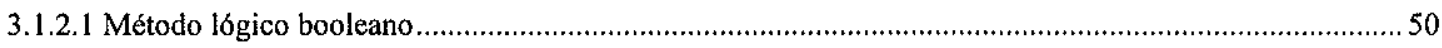

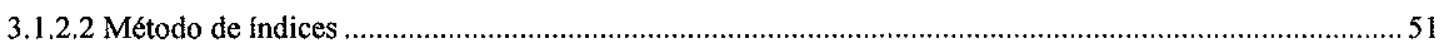

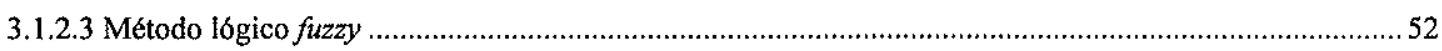

3.1.2.4 Avaliação de favorabilidade a partir de critérios múltiplos por geoprocessamento.................................54

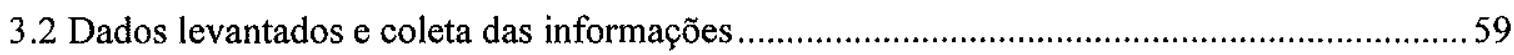

3.2.1 Digitalização da topografia e da rede de drenagem .............................................................59

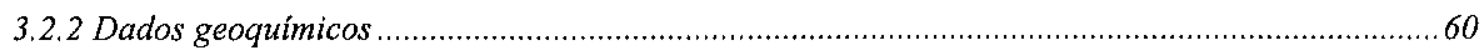

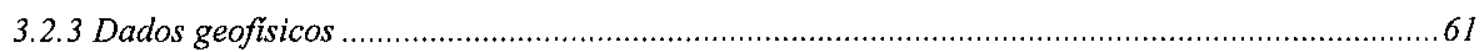

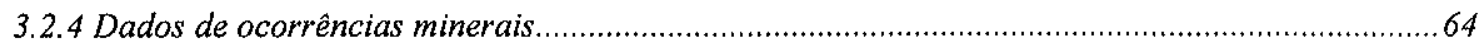

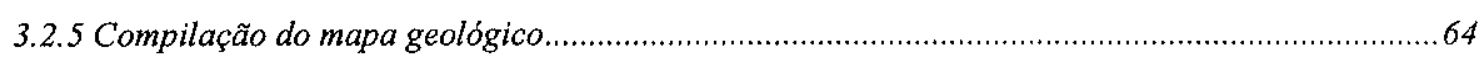




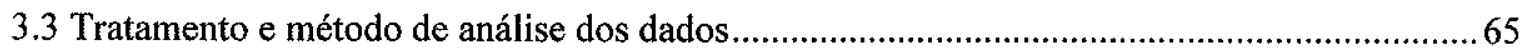

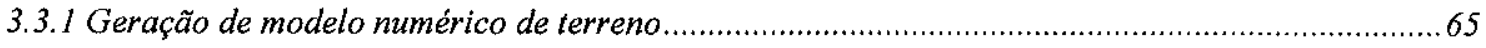

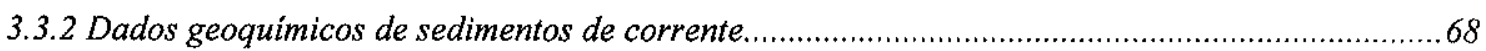

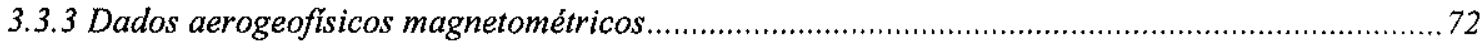

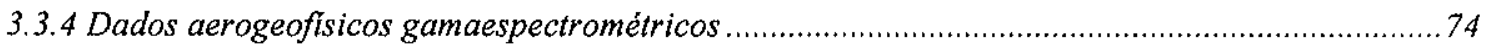

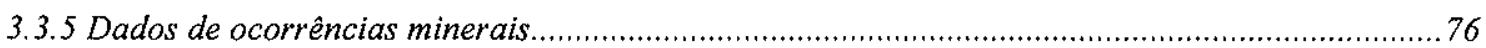

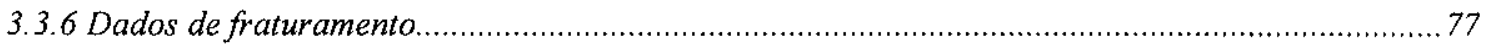

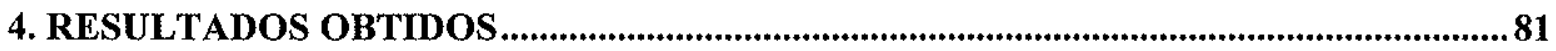

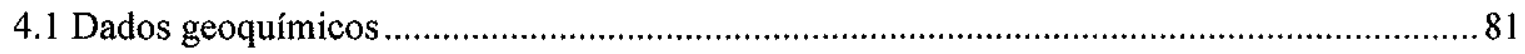

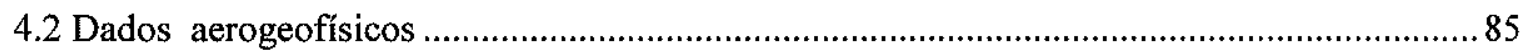

4.2.1 Magnetometria

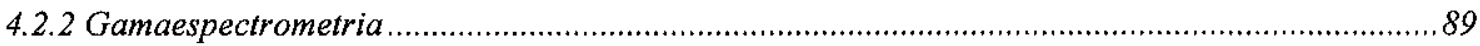

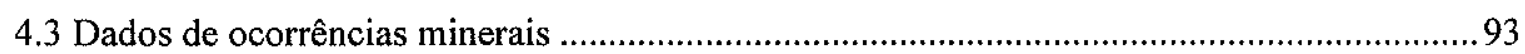

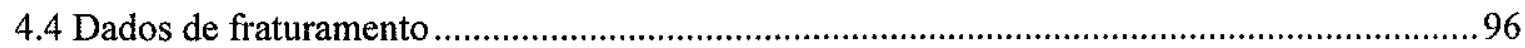

5. INTEGRAÇÃO DE DADOS E SELEÇÃO DE ÁREAS FAVORÁVEIS .............................. 101

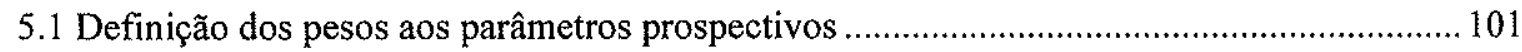

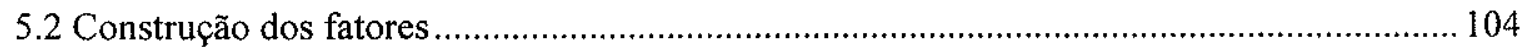

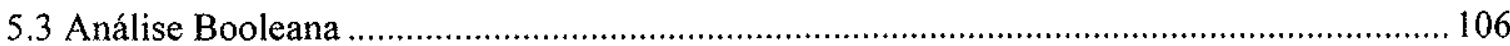

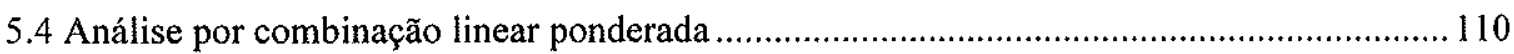

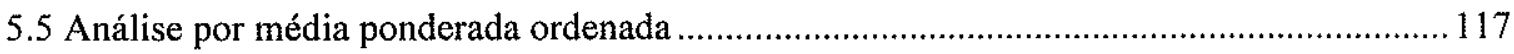

5.6 Comparação entre as análises por combinação linear ponderada e média ponderada ordenada

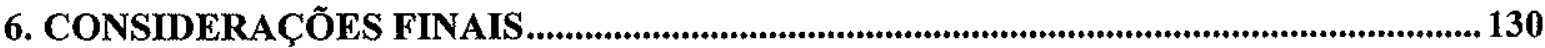

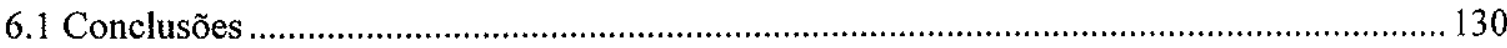

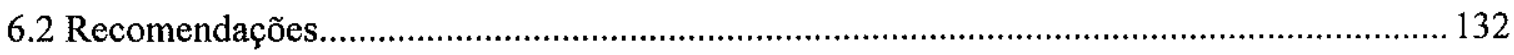

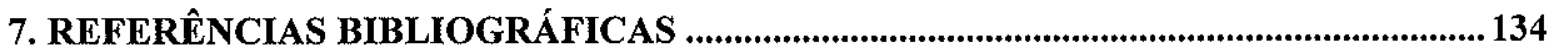

Índice de quadros

Quadro 1:Esquema estratigráfico da área de estudo 4 
Indice de tabelas

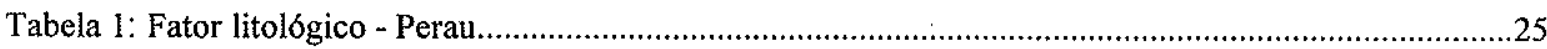

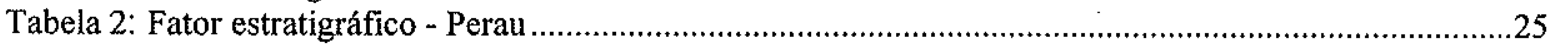

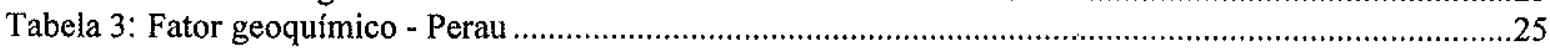

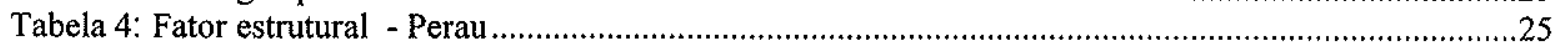

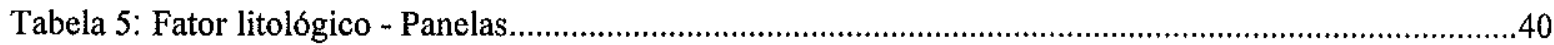

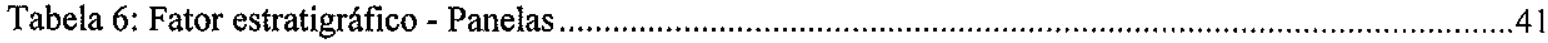

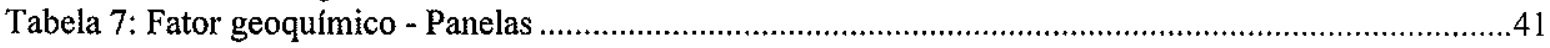

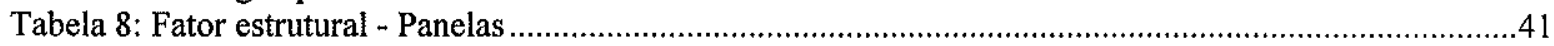

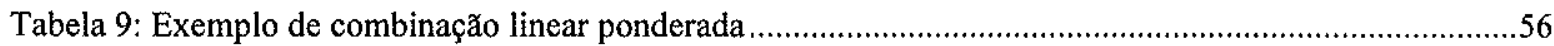

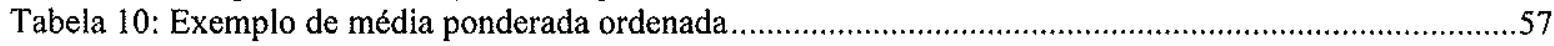

Tabela 11: Exemplo de média ponderada ordenada - inversão dos pesos de ordenação .....................................58

Tabela 12: Exemplo de média ponderada ordenada - pesos de ordenação iguais ............................................58

Tabela 13: Cartas topográficas digitalizadas ........................................................................................5

Tabela 14: Erros de digitalização com captura contínua de pontos.................................................................60

Tabela 15: Relação de levantamentos geoquímicos da Mineropar no Vale do Ribeira ...................................61

Tabela 16: Características técnicas do projeto Serra do Mar Sul ................................................................61

Tabela 17: Características técnicas do projeto São Paulo - Rio de Janeiro ....................................................62

Tabela 18: Dados utilizados na compilação do mapa geológico ..........................................................................64

Tabela 19: Parâmetros de redução ao polo dos dados magnéticos ................................................................73

Tabela 20: Recurso Geologico "in situ" - Depósitos tipo Perau........................................................................93

Tabela 21: Recurso Geologico "in situ" - Depósitos tipo Panelas.................................................................93

Tabela 22 :Parâmetros prospectivos - fator litológico - Panelas ....................................................................102

Tabela 23: Parâmetros prospectivos - fator estratigráfico - Panelas...........................................................102

Tabela 24: Parâmetros prospectivos - fator geoquímico - Panelas ........................................................................102

Tabela 25: Parâmetros prospectivos - fator estrutural - Panelas...........................................................................102

Tabela 26: Parâmetros prospectivos - fator litológico - Perau ...........................................................................103

Tabela 27: Parâmetros prospectivos - fator estratigráfico - Perau ................................................................. 103

Tabela 28: Parâmetros prospectivos - fator geoquímico - Perau .................................................................... 103

Tabela 29: Parâmetros prospectivos - fator estrutural - Perau .....................................................................103

Tabela 30: Reclassificação do fator litológico - Panelas ..........................................................................105

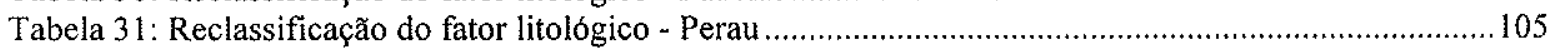

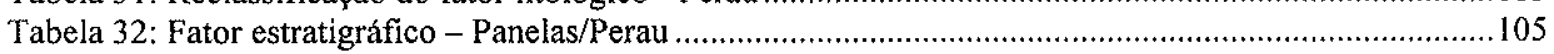

Tabela 33: Reclassificaçđ̃o do fator geoquímico - Panelas/Perau ............................................................105

Tabela 34: Reclassificação do fator estrutural - Panelas.............................................................................105

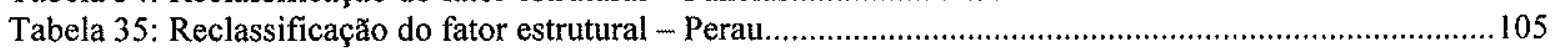

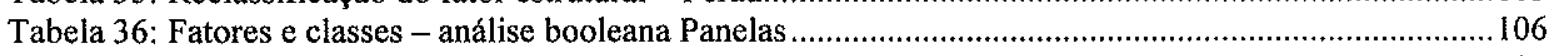

Tabela 37: Fatores e classes - análise booleana Perau .................................................................................107

Tabela 38: Tabulação cruzada - análise booleana Panelas .............................................................................107

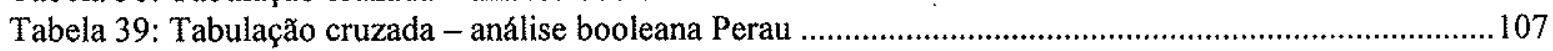

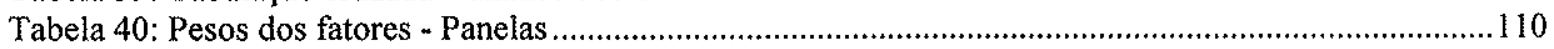

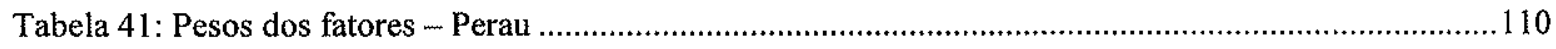

Tabela 42: Escala de pesos - Idrisi ...................................................................................................111

Tabela 43: Pesos de compensação obtidos a partir do módulo WEIGHT para a análise Panelas ...................111

Tabela 44: Pesos de compensação obtidos a partir do módulo WEIGHT para a análise Perau .....................111

Tabela 45: Quadro resumo simplificado - análise por combinação linear - Panelas ...................................112

Tabela 46: Quadro resumo simplificado - análise por combinação linear - Perau .......................................113

Tabela 47: Tabulação cruzada - Panelas - análise por combinação linear ponderada ....................................113

Tabela 48: Tabulação cruzada - Perau - análise por combinação linear ponderada.....................................113

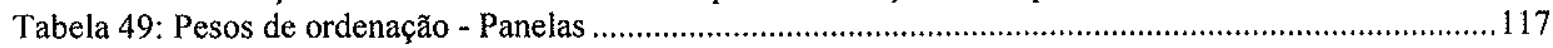

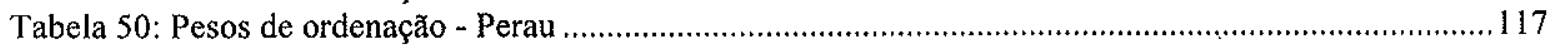

Tabela 51: Tabulação cruzada - Panelas - análise por média ponderada ordenada. ..........................................118

Tabela 52: Tabulação cruzada - Perau - análise por média ponderada ordenada........................................118

Tabela 53: Quadro resumo simplificado - análise por média ponderada ordenada - Panelas ........................120

Tabela 54: Quadro resumo simplificado - análise por média ponderada ordenada - Perau ...........................121

Tabela 55: Tabulação cruzada proporcional - tipo Panelas ………………….................................................124

Tabela 56: Tabulação cruzada proporcional - tipo Perau ...............................................................................125 


\section{Indice de figuras}

Figura 1: Localização da área de estudo.

Figura 2: Articulação das folhas Cerro Azul e Apiaí, ................................................................................2

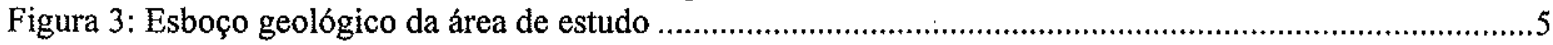

Figura 4: Mineralização submarina exalativa, hipotética, de sulfetos e barita hospedados em sedimentos....16 Figura 5: Modelo genético interpretativo das mineralizaçðes epigenéticas de chumbo do Vale do Ribeira....33

Figura 6: Correlação entre ocorrências minerais do tipo Panelas e distância dos granitos ............................40

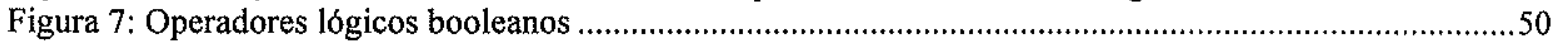

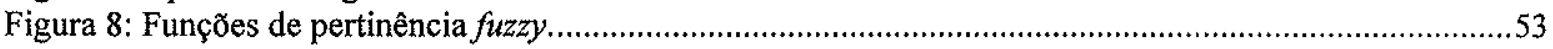

Figura 9: Esquema do modelo numérico de terreno TIN . .................................................................66

Figura 10: Modelo Numérico de Terreno - integração IHS com relevo sombreado, iluminação a partir de

$\mathrm{N} 45 \mathrm{~W}$ com inclinação de $45^{\circ}$.

Figura 11: Exemplo de gráfico do programa Probplot aplicado a população de dados de um levantamento geoquímico.

Figura 12: Fluxograma com as principais etapas para traçar bacias de drenagem automaticamente no Arclnfo

7.1 a partir dos pontos de amostragem de sedimentos de corrente ...............................................

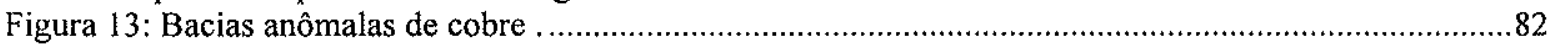

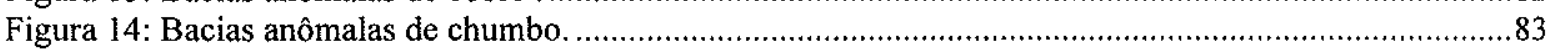

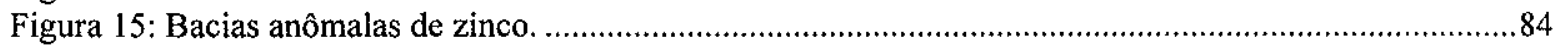

Figura 16: Integração IHS - magnetometria reduzida ao polo com primeira derivada vertical da

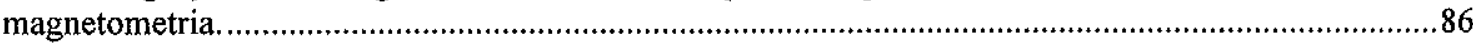

Figura 17: Integração IHS entre primeira derivada vertical da magnetometria e magnetometria sem tratamento.

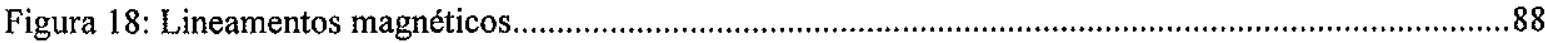

Figura 19: Mapas de distribuição de teores em ppm dos canais aerogeofísicos: Tório, Urânio, Potássio e razão $\mathrm{Th} / \mathrm{K}$.

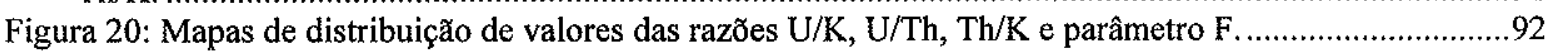

Figura 21: Tonelagens dos depósitos sedimentar exalativos.............................................................94

Figura 22: Teores de zinco em depósitos de $\mathrm{Zn}-\mathrm{Pb}$ sedimentar exalativo..............................................95

Figura 23: Teores de prata em depósitos sedimentar exalativos. .............................................................95

Figura 24: Teores de chumbo em depósitos sedimentar exalativos.....................................................96

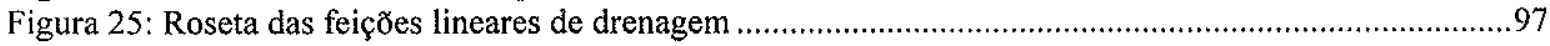

Figura 26: Feições lineares interpretadas da rede de drenagem. ......................................................98

Figura 27: Figura com mapas de isofrequência de zonas de fraturamento segundo as direções: N60W,

N30W, NS, N45E e N70E com tolerância de 10 graus............................................................99

Figura 28: Interpretaçđ̃o das áreas com maior freqüência de zonas de fraturamento ................................100

Figura 29: Mapa de favorabilidade - Análise booleana Panelas............................................................108

Figura 30: Mapa de favorabilidade - Análise booleana Perau................................................................. 109

Figura 31: Fluxograma do processo de análise por combinação linear ponderada ....................................114

Figura 32: Mapa de favorabilidade - Análise por combinação linear ponderada - Panelas.........................115

Figura 33: Mapa de favorabilidade - Análise por combinação linear ponderada - Perau............................116

Figura 34: Fluxograma do processo de análise por média ponderada ordenada ......................................119

Figura 35: Mapa de favorabilidade - Análise por média ponderada ordenada - Panelas...........................122

Figura 36: Mapa de favorabilidade - Análise por média ponderada ordenada - Perau.............................123

Figura 37: Áreas coincidentes entre as análise de favorabilidade por média ponderada ordenada e combinação linear ponderada para o tipo Panelas, com índices de favorabilidade (1-10) ................................ 126

Figura 38: Áreas coincidentes entre as análise de favorabilidade por média ponderada ordenada e combinação linear ponderada para o tipo Perau, com índices de favorabilidade $(1-10)$....................................127

Figura 39: Detalhe das análises por média ponderada ordenada e combinação linear ponderada, para o tipo Perau, na área da Fm. Perau.

Figura 40: Detalhe das análises por média ponderada ordenada e combinação linear ponderada, para o tipo Panelas, na área região de Adrianópolis. 


\section{Resumo}

Neste trabalho é descrita a aplicação de técnicas de geoprocessamento na avaliação da favorabilidade de mineralizações de metais básicos, na área das folhas Cerro Azul e Apiaí (SG.22-X-B-IV e SG.22-X-B-V), escala 1:100.000, Vale do Ribeira (SP e PR).

O método utilizado baseia-se na seleção e ponderação de parâmetros prospectivos e aplicação destes segundo técnicas de geoprocessamento em um banco de dados digitais, o qual é composto por dados geológicos, geoquímicos, aerogeofísicos e de ocorrências minerais.

A seleção dos parâmetros prospectivos e as análises foram feitas com base em dois modelos de mineralização: o tipo Panelas, filonar hidrotermal encaixado em rochas carbonáticas, e o tipo Perau, sedimentar-exalativo.

A sobreposição dos niveis de informação, gerados a partir dos parâmetros prospectivos e do banco de dados foi efetuada pelos seguintes métodos: booleano, combinação linear ponderada e média ponderada ordenada.

O método booleano não foi considerado adequado para análise de favorabilidade nos casos estudados. Os métodos por combinação linear ponderada e média ponderada ordenada mostraram-se adequados para este tipo de análise, na área de estudo, com resultados semelhantes entre si.

A análise por média ponderada ordenada definiu os melhores resultados, com os mapas de favorabilidade obtidos mostrando um maior número de classes em pequenas áreas. Em comparação, a análise por combinação linear ponderada apresentou resultados coerentes, mas sem detalhar as áreas menores.

Os parâmetros prospectivos desenvolvidos mostraram-se adequados qualitativamente e quantitativamente, tanto para o tipo Perau quanto para o tipo Panelas.

Conclui-se que o método utilizado é adequado à seleção de áreas para pesquisa geológica em detalhe a baixos custos, podendo ser aplicado em áreas semelhantes à estudada. 


\begin{abstract}
This work describes the use of GIS techniques in the evaluation of basemetal mineralizations favorability. The target area comprises Cerro Azul and Apiai quadrangles (SG.22-X-B-IV and V, scale 1:100.000), Vale do Ribeira, São Paulo and Paraná States.

The applied method is based on selection, weighting and application of prospective parameters using GIS techniques to a digital database, which is composed of geological, geochemical and airborne geophysics data and mineral ocurrences.
\end{abstract}

The exploration parameters selection and analysis were made based on two mineralization models: Panelas type, vein-type carbonate hosted, and Perau type, sedimentary-exhalative.

The layers overlay, generated from prospective parameters and from the database was done by means of the boolean, weighted linear combination and ordered weighted averaging methods.

The boolean method was not considered suitable for favorability analysis whereas the weighted linear combination and ordered weighted averaging methods proved to be suitable for the studied area, yielding similar results.

The ordered weighted averaging analysis defined the best results, the favorability maps presenting a large number of classes in the minor areas. In comparison, the weighted linear combination analysis showed more coherent results, but without detailing the minor areas.

The developed prospective parameters were considered suitable for both Perau and Panelas types.

It is concluded that the methods used are suitable for selection of prospecting areas during detailed geological survey, keeping low cost, and can be applied to similar areas as the studied one. 


\section{Introdução}

\subsection{Considerações iniciais}

O Vale do Ribeira é uma região cuja geologia tem sido estudada há décadas devido ao seu potencial mineral para minérios metálicos, especialmente sulfetos de metais como chumbo, zinco e cobre dos quais conhecem-se numerosas mineralizações.

Os trabalhos de prospeç̧ão mineral realizados na área fizeram o levantamento de uma grande quantidade de informações como mapeamentos geológicos, dados geoquímicos e geofísicos, além da compilação de ocorrências minerais.

A organização destes dados é fator importante no processo de avaliação da favorabilidade para mineralizações de chumbo, zinco e cobre na regiăo e o êxito do trabalho é fortemente condicionado pelos modelos de mineralização empregados para a manipulação e interpretação dos dados levantados em campo.

A busca de técnicas e ferramentas adequadas para a manipulação e interpretação dos dados e modelos conduz ao uso de sistemas digitais de informação geográfica.

\subsection{Objetivos e métodos}

Este trabalho tem por objetivo a análise de favorabilidade mineral para metais básicos numa área do Vale do Ribeira, utilizando-se técnicas de geoprocessamento. Desta forma, busca-se: definir as áreas mais favoráveis as mineralizações de chumbo, zinco e cobre; a avaliação dos métodos de análise por geoprocessamento empregados; a avaliação dos mapas de favorabilidade resultantes e a verificação da adequação dos modelos prospectivos empregados quando aplicados por geoprocessamento.

Esta análise de favorabilidade tem enfoque em dados geológicos visando a priorização de alvos para prospecção.

O método utilizado baseia-se no desenvolvimento de modelos de prospecção segundo técnicas de geoprocessamento aplicadas a um banco de 
dados geológicos, geoquímicos, geofísicos e de ocorrências minerais, digitalizados e espacialmente registrados. Tem como base a ponderação de parâmetros prospectivos, segundo sua importância relativa e absoluta atribuída por peritos.

\subsection{Localização}

A área investigada localiza-se no sul do estado de São Paulo e nordeste do estado do Paraná, na região denominada Vale do Ribeira de Iguape (figura 1). Abrange uma área de aproximadamente $5.800 \mathrm{~km}^{2}$, que corresponde às folhas Cerro Azul e Apiaí, escala 1:100.000. É delimitada pelos paralelos $24^{0} 30^{\prime} \mathrm{S}$ e $25^{\circ} 00^{\prime} \mathrm{S}$, e pelos meridianos $48^{\circ} 30^{\prime} \mathrm{W}$ e $49^{\circ} 30^{\prime} \mathrm{W}$. A articulação das folhas 1:100.000 em relação a folha Itararé, 1:250.000 é apresentada na figura 2.

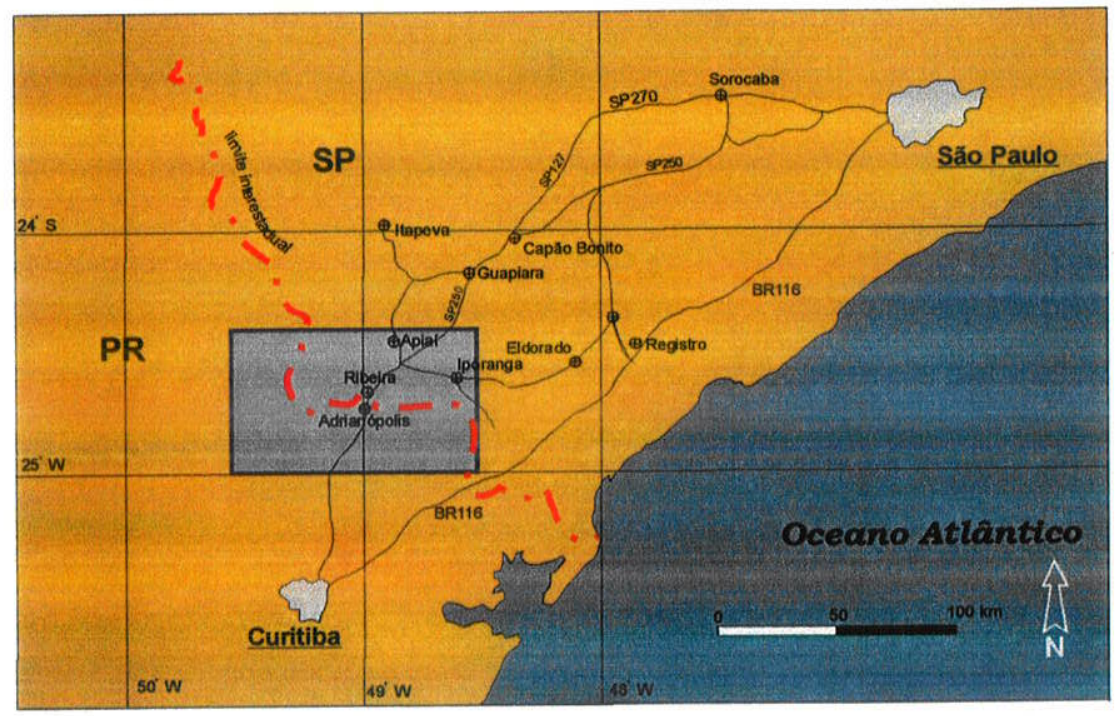

Figura 1: Localização da área de estudo.

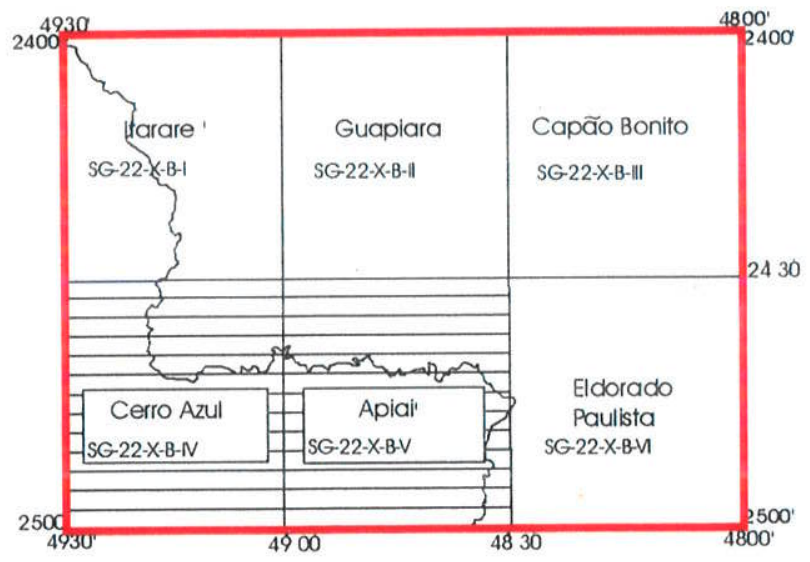

Figura 2: Articulação das folhas Cerro Azul e Apiaí (o quadro em vermelho corresponde a folha Itararé, 1:250.000). 


\section{Dados anteriores}

\subsection{Geologia}

Segundo (Campanha et al., 1996) no Vale do Ribeira, dentro da área de estudo, predominam rochas supracrustais de grau metamórfico fraco a médio, reunidas no Supergrupo Açungui (Mesoproterozóico a Neoproterozóico). Este é subdividido nos Grupos Itaiacoca, Votuverava (Subgrupos Ribeira e Lajeado), Setuva e Formações Água Clara e Capiru. O embasamento dessas supracrustais é constituído por rochas gnáissico-migmatíticas, com núcleos charnockíticos e intercalações de metassedimentos, representado pelo complexo Gnáissico Migmatítico (Paleoproterozóico). Granitos do Neoproterozóico, corpos alcalinos do Cretáceo e diques básicos do Mesozóico cortam as seqüências metassedimentares e seu embasamento. Acompanhando os principais rios ocorrem depósitos quaternários aluvionares e coluvionares.

As principais unidades litoestratigráficas da área são apresentadas na figura 3 e o mapa geológico é apresentado no anexo II. Ainda segundo Campanha et al. (1996), uma possivel organização das unidades litoestratigráficas da área de estudo seria o apresentado no esquema do quadro 1. 


\section{Quaternário}

Aluviões e coluviões.

\section{Cretáceo}

Suítes e corpos alcalinos.

Jurássico - Cretáceo

Intrusivas básicas.

Triássico - Jurássico

Corpos gábricos

\section{Neoproterozóico a Cambro - Ordoviciano}

Suites e corpos graníticos pós-tectônicos

\section{Neoproterozóico}

Suites e corpos graníticos sin- a tardi-tectônicos.

Complexos granitóides.

Gabro de Apiaí

Mesoproterozóico à Neoproterozóico

Supergrupo Açungui

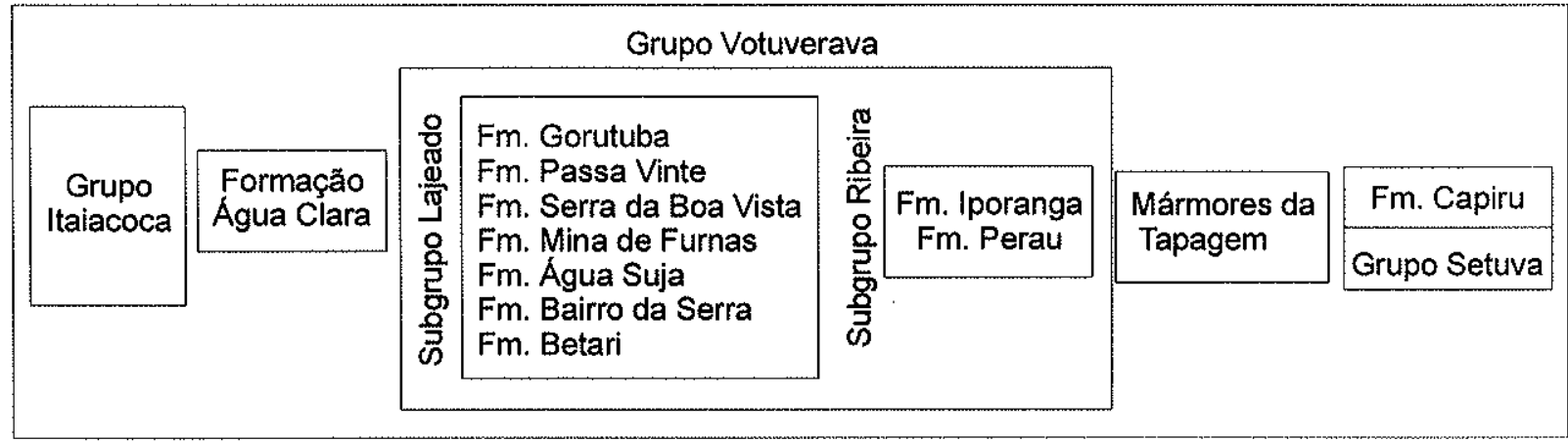

\section{Paleoproterozóico}

Complexo gnássico-migmatítico.

Baseado em Campanha (1991 e informação verbal)

Quadro 1: Estratigrafia da área de estudo 


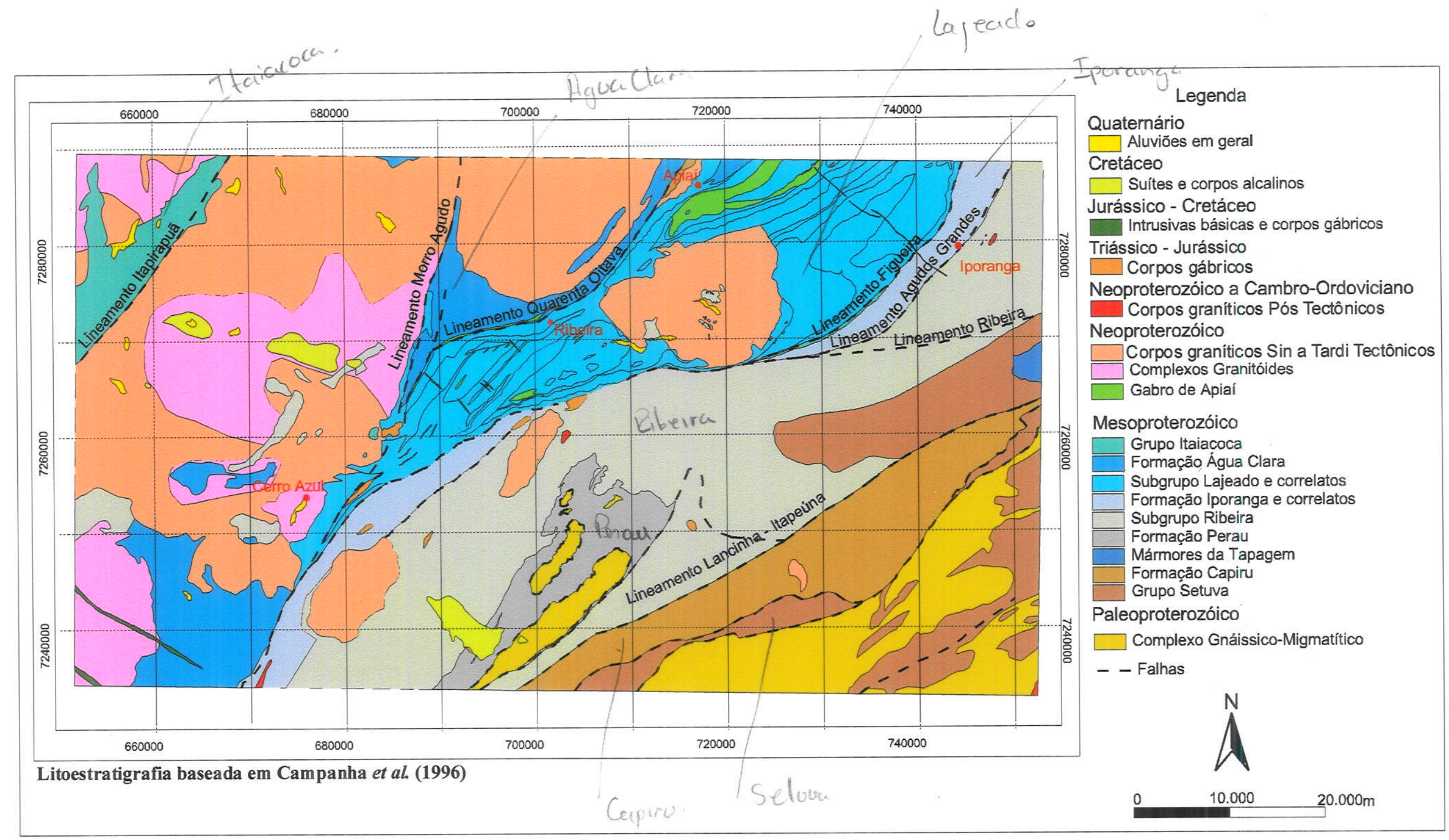

Figura 3: Principais unidades litoestratigráficas da área de estudo. 


\subsubsection{Litoestratigrafia}

Descreve-se a geologia da área de estudo, com ênfase na composição litológica dos pacotes estratigráficos (mapa geológico no anexo II). $O$ texto apresentado é baseado em Campanha et al. (1996). A divisão estratigráfica apresentada é baseada nas propostas de Campanha et al. (1987), Campanha (1991) e Campanha et al. (1996 e informação verbal).

\section{a. Paleoproterozóico}

\section{a.1 Complexo Gnáissico-Migmatítico}

$\mathrm{Na}$ área de estudo afloram rochas do Paleoproterozóico que correspondem ao Complexo Gnáissico-Migmatítico (Campanha et al., 1996), composto por migmatitos embrechíticos e nebulíticos, granito-gnaisses, migmatitos estromalíticos com paleossomas de anfibólio-biotita, biotita-hornblenda gnaisses predominantes, mica-quartzo xistos, ultrabasitos, metabasitos e anfibolitos subordinados, ortognaisses (a biotita, biotita-hornblenda, hornblenda e muscovita) de composição diorítica a granodiorítica, com intercalações de quartzitos, anfibolitos, metabasitos e metaultrabasitos. Afloram principalmente na região sudeste da área de estudo, tendo uma disposição SW-NE. Essas rochas constituem o embasamento cristalino ao sul da faixa metassedimentar.

b. Mesoproterozóico a Neoproterozóico

b.1 Supergrupo Açungui

\section{b.1.1 Grupo Setuva}

O Grupo Setuva foi definido originalmente por Bigarella \& Salamuni (1956a,b, 1958a,b).

Segundo Campanha et al. (1996), o Grupo Setuva engloba todas as unidades metassedimentares aflorantes no Anticlinal do Setuva subjacentes à Formação Capiru. 
As litologias do grupo Setuva, aflorantes na área, são compostas basicamente por metapelitos (filitos e xistos finos) com presença de mármores, quartzo xistos e quartzitos. Ocorrem raras intercalações de metabasitos.

\section{b.1.2 Formação Capiru}

A Formação Capiru foi definida por Bigarella \& Salamuni (1956a). Segundo Campanha et al. (1996), essa Formação, da mesma forma que o Grupo Itaiacoca, corresponde a uma seqüência plataformal de águas rasas e litorâneas, com alternâncias de pacotes carbonáticos, psamíticos e pelíticos.

A Formação Capiru é composta por filitos, metassiltitos, filitos grafitosos, metarritmitos e ardósias, mármores dolomíticos e dolomitos com finas intercalações de metachert, quartzitos, metarenitos, metarcóseos e hornfels. Destaca-se a presença nos mármores dolomíticos de estruturas indicativas de águas rasas, tais como estromatólitos e oólitos.

\section{b.1.3 Mármores da Tapagem}

Segundo Campanha (1991) são mármores finos, brancos, isótropos, homogêneos e dolomíticos. Ocorrem intercalações de cálcio xistos, mica-quartzo xistos e quartzitos.

Campanha (1991) levanta a hipótese de que o Mármore da Tapagem seja correlato aos mármores da Formação Capiru e embora não se encontrem estruturas primárias, como estromatólitos, sua posição estratigráfica e aspectos composicionais sugerem esta correlação.

\section{b.1.4 Grupo Votuverava}

Definido originalmente como Formação Votuverava (Bigarella e Salamuni, 1958b) teve sua elevação a Grupo proposta por Campanha (1991) e Campanha et al. (1996) É subdividido nos Subgrupos Ribeira e Lajeado. 


\section{b.1.4.1 Subgrupo Ribeira}

O Subgrupo Ribeira, segundo Campanha et al. (1996), é composto por metarritmitos, predominantemente metassiltitos finos, ardósias e filitos com intercalações de quartzo filitos, quartzitos, carbonato filitos, metassiltitos, metaargilitos maciços, clorita filitos, xistos verdes, filitos grafitosos, metaconglomerados oligomíticos, mármores, metacherts, formações ferríferas e metatufos, com expressivas intercalações de rochas metabásicas, representadas por anfibolitos, epídoto-actinolita fels e clorita-carbonato fels.

\section{b.1.4.1.1 Formação Perau}

Foi definida por Pierkarz (1981) e Takahashi et al. (1981)

Segundo Campanha et al. (1996), a coluna estratigráfica proposta por Takahashi et al. (1981) na sua área-tipo inclui a Seqüência Química Superior, a Seqüência Clastoquímica e a Seqüência Química Inferior de Schöll et al. (1982). A primeira corresponde a um nivel carbonático impuro, que abriga a mineralização da Mina do Perau e outras correlatas. A segunda corresponde a um espesso pacote de quartzitos, por vezes interpretados como metacherts, o qual delimita algumas grandes estruturas antiformais, como a da Anta Gorda. O conceito adotado por Campanha et al. (1996) é mais restrito do que o proposto por Fritzons Jr et al. (1982) e Biondi et al. (1983) sendo mais próximo do conceito original de Pierkarz (op. cit.) e Takahashi (op. cit.).

Daitx (1996) adota a nomenclatura de Complexo Perau numa área que engloba a Formação Perau e parte do Subgrupo Ribeira, apresentados neste trabalho. Daitx (1996) descreve três conjuntos litológicos principais no Complexo Perau:

- Seqüência inferior ou quartzítica - composta principalmente por quartzitos, que representam a principal camada-guia do Complexo Perau.

- Seqüência intermediária ou carbonática/pelítico-carbonática - formada por mármores dolomíticos e, subordinadamente, calcíticos. 
- Seqüência superior ou pelítico-aluminosa/anfibolítica - este conjunto litológico é composto por dois litotipos principais: metassedimentos síltico-argilosos e anfibolitos/anfibólio xistos.

A Formação Perau, aqui adotada, é composta por quartzo-muscovita-biotita xistos, com intercalações locais de quartzitos, xistos com plagioclásio, granada, anfibólio e magnetita, alternância de mármores dolomíticos e mica xistos com tremolita, quartzitos finos, carbonato xistos com intercalações de mármore, metavulcânicas básicas a ácidas, incluindo anfibolitos, epídoto-actinolita fels, clorita-carbonato fels e prováveis metatufos.

\section{b.1.4.1.2 Formação Iporanga}

Foi definida por Leonardos (1934), ocorrendo no canto nordeste da área de estudo, numa faixa de direção SW-NE, ao sul do Lineamento Ribeira. Ocorre também no Paraná sempre a sul do Lineamento Ribeira.

A Formação Iporanga é composta por metarritmitos, metassiltitos, filitos $\mathrm{e}$ ardósias, com intercalações de metaconglomerados e metabrechas polimíticas com matriz filítica, metarenitos (por vezes conglomeráticos), metarcóseos, metarenitos e metaconglomerados polimíticos de matriz arcoseana, quartzitos com intercalações de metassiltitos e hornfels.

\section{b.1.4.2 Subgrupo Lajeado}

Denominação proposta por Campanha et al. (1986) tem sua divisão estratigráfica interna reconhecida desde Barbosa (1941). Trata-se de uma sequeência plataformal de águas rasas, porém não litorâneas (Petri \& Suguio, 1969) constituída pela alternância de pacotes relativamente espessos de composição carbonática e psamo-pelítica. Hasui \& Oliveira et al. (1984) propuseram uma coluna estratigráfica formal, a qual foi modificada por Campanha et al. (1986) e adotada neste trabalho. Abaixo estão descritas as unidades desta coluna (da base para o topo as formações: Betari, Bairro da Serra, Água Suja, Mina de Furnas, Serra da Boa Vista, Passa Vinte e Gorutuba). 


\section{b.1.4.2.1 Formação Betari}

A Formação Betari, unidade basal do Subgrupo Lajeado, é formada por metassiltitos e filitos, com intercalações de metarenitos finos, na parte SW da área, transformados para quartzo-biotita-muscovita xistos e na base da Formação ocorrem lentes de metaconglomerados oligomíticos, em meio a metarenitos arcoseanos, metarenitos com grânulos e metassiltitos.

\section{b.1.4.2.2 Formação Bairro da Serra}

Trata-se de uma unidade de natureza carbonática. Encontram-se mármores finos (metacalcários), cinza-escuros a médios, homogêneos, localmente bandados, em geral calcíticos com intercalações de filitos e xistos carbonáticos, filitos e metassiltitos.

\section{b.1.4.2.3 Formação Água Suja}

Ocorrem filitos, quartzo-biotita-muscovita xistos, clorita-quartzo-muscovita xistos e quartzo-grafita-muscovita xistos. Na proximidade do granito Itaoca, as rochas apresentam-se fortemente afetadas por metamorfismo de contato.

\section{b.1.4.2.4 Formação Mina de Furnas}

Constituída essencialmente por mármores impuros, margosos, localmente bandados, calcíticos com intercalações de filitos carbonáticos, metarenitos e xistos. Suas características morfológicas, litotipos e estruturas são semelhantes às da Formação Bairro da Serra.

\section{b.1.4.2.5 Formação Serra da Boa Vista}

Caracteriza-se pela presença de metarenitos bandados, localmente microconglomeráticos com intercalações de filitos, metassiltitos, e localmente muscovita-biotita xistos e mica xistos. 


\section{b.1.4.2.6 Formação Passa Vinte}

É constituída por mármores em geral bandados, cinza-escuro a claros e dolomíticos, por vezes impuros. Observam-se localmente esteiras algálicas.

\section{b.1.4.2.7 Formação Gorutuba}

Segundo Campanha (1991), a característica mais marcante desta unidade é a alternância rítmica de lâminas e estratos centimétricos e milimétricos. Predominam os metapelitos, ocorrendo cálcio-silicáticas (informalmente Gorutubitos, Geofrey \& Santos, 1942, apud Campanha, 1991). De modo geral, encontram-se metassedimentos rítmicos, incluindo metassiltitos, filitos carbonáticos, mármores e filitos cálcio-silicáticos.

\section{b.1.4.2.8 Gabro de Apiaí}

Trata-se de uma intrusão de gabros nos metassedimentos do Subgrupo Lajeado. Esta unidade mostra relações de contato discordantes, além de metamorfismo de contato sobre as rochas da Formação Gorutuba (Campanha, 1991). É constituído por rochas isótropas de granulação média, escuras, textura variando de ofítica a subofítica com presença de plagioclásio e augita.

\section{b.1.5 Formação Água Clara}

Definida, originalmente, por Marini et al. (1967), corresponde a uma seqüência carbonática impura, com posição estratigráfica provável no topo do Supergrupo Açungui, situação esta controversa em trabalhos posteriores.

É composta por rochas cálcio-silicáticas, cálcio xistos, carbonato xistos, mármores e intercalações de quartzitos, mica xistos, metabasitos, metaultramáficas, filitos e paragnaisses, mármores, mica xistos, anfibólio xistos, quartzitos, granada-clorita-biotita xistos, metacherts, metatufos básicos e 
intermediários, metabasitos e cornubianitos, orto-anfibolitos, carbonato-anfibolitos e ortognaisses parcialmente migmatizados.

\section{b.1.6 Grupo Itaiacoca}

Corresponde a uma seqüência plataformal de águas rasas e litorâneas (Petri \& Suguio, 1969), com espessos pacotes carbonáticos, psamíticos e pelíticos, definido por Almeida (1956) como formação.

É composto por filitos, sericita xistos, metassiltitos, metargilitos, filitos grafitosos, ardósias e metarritmitos. Subordinadamente, metarenitos, quartzitos, mármores dolomíticos e clorita xistos, mármores dolomíticos com estruturas estromatolíticas e raras oolíticas e pisolíticas. Ocorrem intercalações de metacherts, metapelitos e xistos carbonosos subordinadamente.

\section{c. Neoproterozóico}

\section{c. 1 Complexos Granitóides}

Rochas Granitóides, de composição e texturas diversas, englobando desde granitóides porfiróides a granitóides pós-tectônicos e, possivelmente, também porções do embasamento.

\section{c.2 Suítes e Corpos Granitícos Sin- a Tardi-Tectônicos}

Compostos por biotita-hornblenda-granitos e granodioritos, porfiríticos e/ou equigranulares, cinza, com enclaves de microgranitos, quartzo dioritos e gnaisses. Ortognaisses predominantes, com migmatitos, granitos de anatexia e milonito gnaisses porfiroblásticos subordinados.

d. Neoproterozóico a Cambro-Ordoviciano

d.1 Suítes e Corpos Graníticos Pós-Tectônicos

Formados por granitóides intrusivos, normalmente equigranulares, róseos, de composição alcáli-feldspato granito e quartzo sienito. 
e. Triássico-Jurássico

\section{e.1 Corpos Gábricos}

Os corpos são formados por olivina gabros, quartzo monzogabros, gabros subofíticos, diabásios e essexitos.

f. Jurássico - Cretáceo

\section{f.1 Intrusivas básicas}

Ocorrem intrusivas básicas e presença de diabásios, lamprófiros e gabros.

\section{g. Cretáceo}

g.1 Suites e corpos alcalinos

$\mathrm{Na}$ área, afloram ijolitos, foiaítos, malignitos, essexitos, jacupiranguitos, piroxenitos, peridotitos, fonólitos, tinguaítos, álcali sienitos, pulaskitos e gabros alcalinos, associados aos maciços de Tunas, Barra do Itapirapuã, Itapirapuã, Mato Preto e Banhadão.

h. Quaternário

\section{h.1 Depósitos aluvionares}

Os depósitos aluvionares são constituídos por areias de granulação variada, cascalhos, siltes e argilas. Ocorrem terraços e depósitos associados à rede de drenagem. 


\subsubsection{Evolução tectônica}

Campanha (1991), baseado em dados estruturais, geocronológicos e petroquímicos, propõe a seguinte seqüência de eventos tectônicos na região:

- 1,8 a $1,7 \mathrm{Ga}$ - abertura de um rifte continental;

- $\quad$ 1,7 a 1,5 Ga - instalação de abertura oceânica, com vulcanismo básico da Formação Perau. Talvez a deposição das plataformas carbonáticas do Itaiacoca e Capiru;

- $\quad 1,4(?)$ a 1,3(?) Ga - fraturamento da margem continental, desenvolvimento de subducção, para NW, arco magmático no Itaiacoca, e talvez uma bacia frontal a arco (Lajeado?);

- $\quad 0,8 \mathrm{Ga}$ - distensão de retroarco, provocando ascensão de magma básico (Gabro de Apiai);

- $\quad$ 0,75 a 0,63 Ga - colisão de blocos continentais (maciços de Joinville e "Cráton do Paraná"), produzindo o principal evento metamórfico;

- $\quad 0,63$ a 0,45 Ga - desenvolvimento do sistema transcorrente (por tectônica de "escape", ou ajuste de blocos continentais) e instalação de bacias pull-apart, com deposição das sequiências molassóides. Magmatismo granitóide "tardi-"e "pós»" tectônico. Resfriamento regional final .

Segundo Campanha \& Sadowski (1998), os sedimentos de origem marinha na área, comprimidos entre o Cráton do Paraná e o fragmento cratônico Luís Alves (Maciço de Joinville), mostram tanto características de margens ativas quanto de passivas e são, provavelmente, o resultado de uma história que ocorreu durante a abertura e o fechamento de um oceano Mesoproterozóico, entre 1,8 e 1,1 Ga. Os aspectos essenciais, utilizados por Campanha \& Sadowski (1998) para formular o modelo tectônico, estão baseados na presença destes dois blocos cratônicos consolidados antes de $1,8 \mathrm{Ga}$; e numa assembléia de margens continentais, aproximadamente simétricas, representadas pelo Grupo Itaiacoca a noroeste e a Formação Capiru a sudeste, e um domínio central com evidência de um gradual aprofundamento da plataforma carbonática (Subgrupo Lajeado, Grupo Votuverava) passando a leste para seqüências turbidíticas distais, com a presença de magmatismo de assoalho oceânico e/ou arco de ilha imaturo (Subgrupo Ribeira, Grupo Votuverava). 


\subsection{Mineralizações sulfetadas no Vale do Ribeira}

\subsubsection{Introdução}

As principais mineralizações de sulfetos de metais básicos, na área de estudo, podem ser agrupadas em dois tipos principais: tipo Perau e tipo Panelas (Fleischer, 1976). O tipo Perau compreende mineralizações estratiformes de origem exalativa hospedadas em sedimentos carbonáticos marinhos. $O$ tipo Panelas compreende mineralizações filonares de origem hidrotermal hospedadas em rochas carbonáticas marinhas.

\subsubsection{Tipo Perau}

\subsubsection{Observações genéticas e descritivas gerais}

As mineralizações tipo Perau são compostas por sulfetos maciços estratiformes hospedados em sedimentos. Um grande número de depósitos, mundialmente, relaciona-se a esta classe. Sawkins (1976) sugeriu o nome de tipo Sullivan para depósitos deste tipo, mas devido à grande variabilidade verificada em diferentes depósitos, é preferivel utilizar, de uma maneira abrangente, a definição de Large (1980) como "depósitos de sulfetos maciços hospedados em sedimentos". Alguns autores (R.B. Silva et al., 1982, Macedo, 1986, Daitx, 1996) incluem estas mineralizações do Vale do Ribeira no tipo sedimentar exalativo (sedex) devido às suas características locais. Este trabalho adota esta classificação no desenvolvimento da análise de favorabilidade.

Segundo Lydon (1990), um modelo de depósito mineral pode ser composto por: um modelo descritivo, o qual trata de feições do conjunto geológico, tais como morfologia, quimismo, mineralogia, zoneamento, entre outras, e por um modelo genético, no qual são apresentadas explicações, racionais e coerentes, das características do tipo de depósito em termos de conhecimento dos processos geológicos. Deste modo, aborda-se, neste texto, o tipo de mineralização sedex segundo seus aspectos descritivos e genéticos gerais reconhecidos em vários depósitos mundialmente. Numa segunda etapa é feita 
uma revisão das características das mineralizacões tipo Perau na área de estudo (item 2.2.2.2), também segundo seus aspectos descritivos e genéticos.

Segundo Carne \& Cathro (1982 apud Goodfellow et al., 1993) o termo sedex é derivado de sedimentar-exalativo e é a forma de descrição mais popular para esta classe importante de depósitos.

Os depósitos tipo sedex são formados pela descarga de fluidos hidrotermais metalíferos no assoalho oceânico. Esta descarga é propiciada pela geração de um processo convectivo em um grande volume de fluido. $O$ processo convectivo ocorre devido a um alto fluxo térmico na litosfera. Os fluidos hidrotermais mineralizados chegam ao assoalho oceânico por meio de de áreas de fraqueza crustal, que funcionam como condutos para sua passagem. Pode ocorrer deposição de metais, na forma de vênulas, nestes condutos formando zonas de stockwork (vide figura 4).

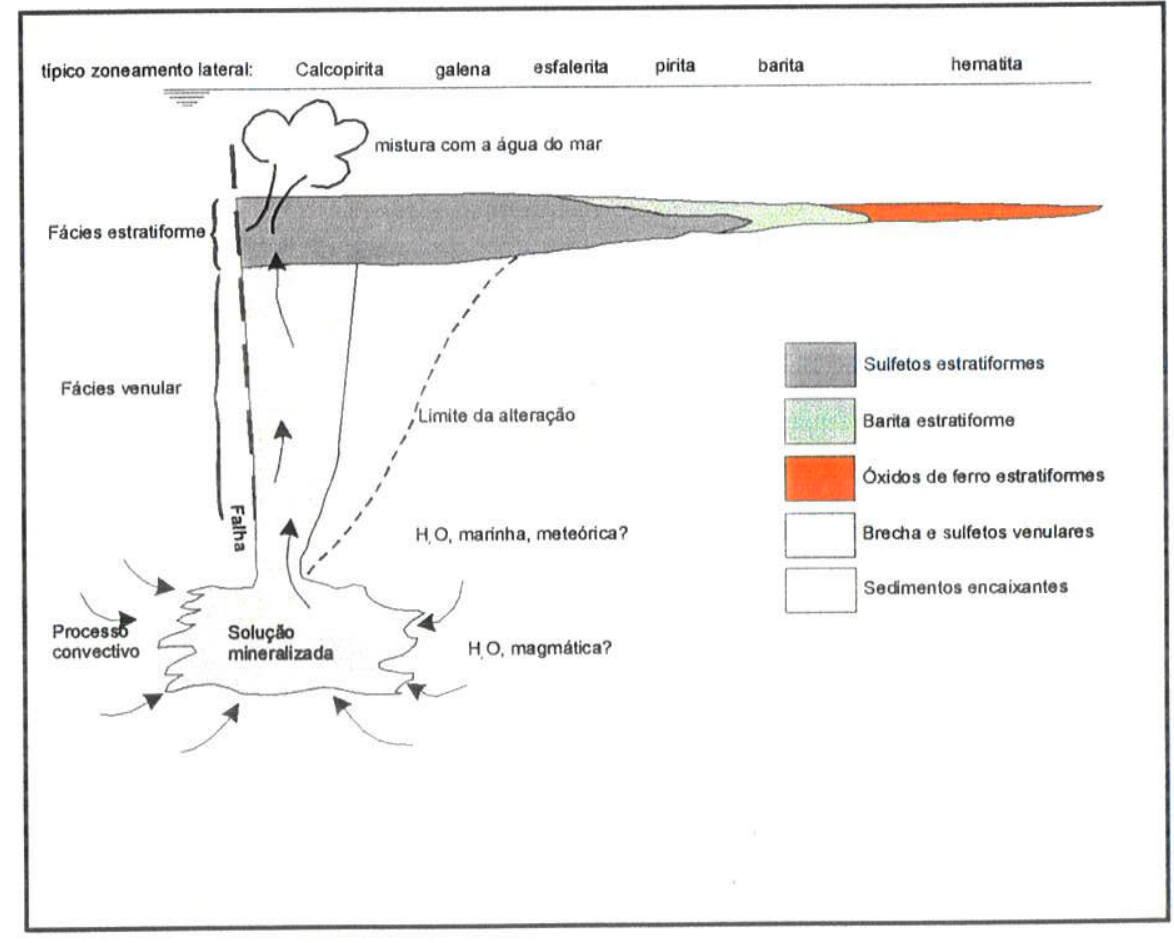

Modificado de Large, 1980 e Finlow-Bates, 1980

Figura 4: Mineralização submarina exalativa, hipotética, de sulfetos e barita hospedados em sedimentos.

Large (1980) destaca os parâmetros que refletem a presença de ambientes geológicos potencialmente mineralizados. Mineralizações submarinas exalativas de chumbo e zinco, hospedadas em sedimentos, usualmente, ocorrem próximos às margens de bacias controladas por falhas. Zonas de eixos de dobra podem sugerir áreas de fraqueza que, desta forma, seriam excelentes caminhos para a 
ascensão de soluções hidrotermais. Resumidamente, a intersecção de lineamentos de eixos de dobras (zonas de charneira) com outros lineamentos, associados com feições indicativas do alto fluxo de calor contemporâneo pode ser a área ideal para a ascensão de soluções hidrotermais à superfície marinha. Segundo o autor, devido à presença de mudanças de fácies e espessuras dos sedimentos hospedeiros, brechas de deslizamento e conglomerados; zonas de dobramento e falhamento de intensidade relativa, maior que a deformação regional pode-se concluir que houve movimento contemporâneo de falhas durante a precipitação das mineralizações estratiformes.

As mineralizações exalativas de sulfetos hospedados em sedimentos marinhos são conhecidas por sua associação com elementos geológicos indicativos da presença de atividade vulcânica contemporânea. Segundo Large (1980) esta atividade é comumente manifestada na forma de tufitos dentro da seqüência sedimentar hospedeira. Intrusões igneas contemporâneas também podem estar presentes na vizinhança do depósito. A evidência de um gradiente geotermal anômalo é um fator muito importante no reconhecimento de uma área potencial para mineralizações exalativas submarinas hospedadas em sedimentos. $\mathrm{O}$ autor conclui que as mineralizações submarinas exalativas hospedadas em sedimentos foram formadas em áreas de alto fluxo térmico, que podem ter resultado em extenso fraturamento da crosta continental nas margens e dentro de crátons. A conseqüência geológica do alto fluxo térmico foi a formação de aberturas e grabens, que podem ter conduzido o desenvolvimento de bacias; além disso, houve atividade ígnea contemporânea à deposição dos sedimentos. $A$ deposição dos sulfetos numa seqüência determinada pelas suas respectivas solubilidades resultou num zoneamento metálico característico (figura 4).

Em termos composicionais os depósitos tipo sedex, segundo Goodfellow et al. (1993) são compostos por sulfetos e outros produtos hidrotermais, tais como carbonatos, chert, barita e apatita, rochas clásticas não hidrotermais, além de rochas sedimentares de origem química e biogênica, também não hidrotermais. $O$ carbonato é um dos componentes principais associado ao hidrotermalismo, e geralmente é composto por: calcita, ankerita e siderita, podendo ocorrer no minério acamadado e nas zonas de alimentação discordantes. Com menor importância, encontram-se óxidos de ferro e minerais argilosos. 
Resumidamente, Large (1980) destaca as principais características das mineralizações hospedadas em sedimentos, como as descritas a seguir:

- a extensão lateral do corpo mineralizado é muitas vezes maior que a espessura;

- os corpos sulfetados são concordantes e intercalados aos sedimentos marinhos de diferentes litologias;

- os corpos mineralizados podem estar distribuidos em intervalos estratigráficos de 1000 m ou mais;

- mineralizações de barita estratiforme freqüentemente estão sobrepostas ou ocorrem lateralmente a mineralizações estratiformes;

- mineralizações filonares, disseminadas ou tipo stockwork são comumente encontradas sob ou adjacentes à mineralização estratiforme;

- mineralogicamente ocorrem pirita e/ou pirrotita, esfalerita e galena. Estudos detalhados podem revelar traços de vários minerais de sulfetos;

- texturalmente os sulfetos estratiformes podem ser maciços, ou seja, sem estrutura interna visivel;

- o zoneamento metálico dentro dos depósitos, idealmente, consiste de uma seqüência lateral de $\mathrm{Cu}-\mathrm{Pb}-\mathrm{Zn}$ ou uma seqüência vertical de $\mathrm{Cu}-\mathrm{Zn}-\mathrm{Pb}-\mathrm{Ba}$.

\subsubsection{Observações genéticas e descritivas - casos no Vale do Ribeira}

A seqüência que hospeda o depósito do Perau é descrita por Fleischer (1976) como constituida por um quartzito na base, apresentando, a seguir, um quartzo filito cinza-grafitoso e sobre este um quartzo-sericita xisto (denominado pelo autor como xisto silicoso). O xisto silicoso apresenta intercalações de calcário e, sobre este, ocorrem cálcio-clorita-anfibólio xistos intercalados com cálcio anfibolitos. Fleischer (1976) descreve a tipologia Perau como uma mineralização plumbo-argentífera, com cobre subordinado, estratiforme, encaixada em seqüência vulcano-sedimentar dobrada e metamorfizada do PréCambriano médio. O autor descreve a mineralização como concentrada num horizonte brechóide com xisto silicoso, calcário e cimento de pirrotita e galena.

Souza \& Campanha (1977), a partir de características da mineralização como extensão, concordância com o acamamento reliquiar e posição 
estratigráfica definida, consideraram a hipótese do chumbo na mineralização do Perau ter origem primária sedimentar.

Barbour \& Oliveira (1979) apresentam uma classificação para mineralizações de sulfetos no Vale do Ribeira segundo um modelo sedimentar. Para estes autores, a mineralização do Perau pode ser classificada como tipo "veio camada", com deposição de metais, na maioria sulfetos, simultaneamente com os sedimentos encaixantes. Após esta deposição e o processo diagenético, 0 metamorfismo modificou, in situ, os constituintes originais dos sedimentos, provocando deformações e migrações locais. Concluem que o chumbo e zinco, mais abundantes do que o cobre, e a prata em teor mais elevado do que o ouro, juntamente com a estrutura e litologias colocam a mineralização do Perau no grupo de jazidas sedimentares não vulcanogênicas (Hutchinson, 1973 apud Barbour \& Oliveira, 1979).

R.B. Silva et al. (1982) relatam como características dessa mineralização: a natureza strata-bound (estratigraficamente controlada); capeamento por formação ferrífera; morfologia lenticular; pirita, galena e esfalerita como sendo os principais minerais sulfetados; prata como metal precioso mais importante; presença de estruturas de deslizamentos; presença de anfibolitos, anfibólio xistos e metadiabásios. Os autores relacionam a mineralização tipo Perau a uma origem exalativa, os fluidos hidrotermais mineralizantes estariam relacionados a salmouras conatas enriquecidas a partir da lixiviação por circulação convectiva nos sedimentos e fundo oceânico. O sistema estaria associado a terrenos com elevado gradiente geotermal, que pode ser expresso, segundo os autores, na forma de derrames e/ou intrusivas hipoabissais de composição básica. Segundo R.B. Silva et al. (1982) "eventualmente estes índicios de magmatismo estão ausentes, e a fonte de energia do sistema é tentativamente interpretada como sendo relacionada a um magmatismo profundo, ou mesmo, a um fluxo anormal de calor na região".

C.R. Silva et al. (1982) associam as mineralizações de Água Clara, Volta Grande, Pretinhos, Canoas e Perau a um mesmo nivel estratigráfico na seqüência Perau. Os autores apresentam os seguintes controles:

- "mineralização definida no nível superior do pacote de rochas carbonáticas sobreposto aos quartzitos basais do Grupo Açungui na área;

- "posicionamento imediatamente abaixo de lentes de barita definidas no topo do referido pacote de rochas carbonáticas;" 
- "níveis magnetíticos bandados sobrepostos à barita;"

C.R. Silva et al. (1982) classificam a mineralização tipo Perau como sedimentar exalativa com base em características tais como: presença de corpos anfibolíticos e de metacherts; rocha encaixante carbonática; chumbo e zinco como elementos predominantes no minério; presença de barita; nível magnetítico bandado junto à mineralização; natureza dos sedimentos originais e a associação deste tipo de seqüência às prováveis bacias restritas. Os autores não identificam rochas vulcânicas junto às mineralizações e atribuem esta ausência a dois fatores: jazimento distal e metamorfismo dos vulcanitos que impede o reconhecimento de sua natureza original.

MMAJ-JICA (1983) definem a mineralização do Perau como um depósito de chumbo estratiforme em rochas calcárias e carbonato xistos.

Lopes (1983) denomina, a partir da geologia da área da mina do Perau, a sub-bacia do Perau. $O$ autor a descreve como uma sub-bacia estreita, alongada e com disposição geral N-S sobre os quartzitos caracterizados regionalmente. A sub-bacia é balizada a leste pelo anticlinal Anta Gorda, a norte pela falha do Perau, a oeste pelas falhas Guararema/Ribeirão Grande e a sul pela falha da Lancinha. O contexto geológico descrito cita uma faciologia com diversos níveis argilo-areno-carbonatados. Lopes (1983) apresenta os principais elementos metalogenéticos da mina do Perau, segundo uma ordenação espacial e temporal de seus metalotectos, definindo fases metalogenéticas com esses elementos.

Macedo (1986), em estudo geoquímico na mineralização do Perau, apresenta outras características de mineralização sedimentar-exalativa baseado na distribuição e zoneamento dos metais e enriquecimento de elementos na capa e lapa da mineralização.

Barbour et al. (1988) definem os traços gerais da mineralização tipo Perau, denominada pelos autores como nivel estratigráfico Perau. As características são as seguintes:

- "Mineralização tipo strata-bound"

- "Atividade vulcânica representada por anfibolitos concordantes, constituindo uma porção menor das rochas locais, inserida em metassedimentos predominantes."

- "Formação ferrífera bandada da fácies óxido, localizada na capa do nível mineralizado."

- "Camada concordante de barita localizada na capa imediata ou associada ao nível mineralizado (Perau SW)." 
- "Corpo de minério lenticular fazendo-se representar por um nível delgado que cobre grande extensão geográfica, ligando quase que continuamente as jazidas e ocorrências do Perau, Canoas, Pretinhos, Água Clara e Araçazeiro. Este nível localiza-se invariavelmente acima de quartzitos basais, inserindo-se estratigraficamente abaixo do nível Panelas."

- "Zoneamento espacial entre o Pb e o Zn, em caráter local (Perau)."

- "Definição genética/tectônica: em seus traços gerais é um nível singenético, deformado e recristalizado tectonicamente, com transposiçðes locais da camada mineralizada."

Barbour \& Macedo (1991) classificam o tipo Perau conforme um modelo exalativo distal em relação à fonte de mineralização, em trabalho que analisa a distribuição espacial dos elementos $\mathrm{Cu}, \mathrm{Pb}, \mathrm{Zn}$ e $\mathrm{Ba}$. Segundo os autores, a mineralização do Perau encontra-se em uma bacia, na qual os depósitos tipo Perau conhecidos como Canoas, Pretinhos, Araçazeiro, Água Clara e Perau SW representam suas bordas N, NE, S, SW e W.

Segundo Daitx (1996), os depósitos tipo Perau correspondem às jazidas tipo sedex (sedimentar-exalativo), formadas por processos hidrotermais-exalativos, em fundo oceânico; assim resumindo, as características das mineralizações são:

- Controle litoestratigráfico, com as ocorrências posicionadas na porção mesosuperior da unidade carbonática/pelítico-carbonática que compõe a seqüência intermediária do Complexo Perau;

- Disposição estratiforme ou strata-bound das mineralizações sulfetadas plumbo-zinciferas e/ou baritíferas;

- Associação entre as mineralizações sulfetadas ( $\mathrm{Pb}-\mathrm{Zn}-\mathrm{Ag}-\mathrm{Fe})$ e corpos baritiferos.

- Formação ferrífera a magnetita na capa dos depósitos;

- Rochas enriquecidas em turmalina na capa e na lapa dos níveis mineralizados;

- Mineralogia sulfetada com galena, esfalerita, pirita, pirrotita e, ocasionalmente, calcopirita;

- Mineralogia da ganga incluindo quartzo, carbonatos, cálcio-silicatos, barita, e com menor freqüência, feldspato baritífero, turmalina e gahnita;

- Encaixantes carbonáticas/cálcio-silicáticas e biotita-sericita xistos, com alto teor em potássio; 
- Zoneamento metálico e mineralógico lateral e vertical, marcados por variações nos teores de chumbo, zinco e bário e/ou conteúdo de galena, esfalerita, barita, pirita, pirrotita e sílica (chert);

- Os corpos de minério sofreram os mesmos eventos tectono-metamórficos que as suas encaixantes, apresentando estruturas bandadas, brechadas ou do tipo stringer,

Daitx (1997) destaca, entre os controles das mineralizações tipo Perau, o controle litoestratigráfico marcado pela seqüência carbonática/pelítico-carbonática do Complexo Perau e o controle pela presença de formações ferriferas capeando as mineralizações. Além disso, o autor comenta os controles tectônicos sindeposicionais (Daitx, 1996), que são marcados pela associação entre as mineralizações e pequenas bacias tectônicas. Estas bacias caracterizam-se pela presença de conglomerados, rochas vulcanoclásticas felsíticas e camadas de sericita-xisto carbonoso. Entre os controles pós-deposicionais, comentados por Daitx (1997), são destacados os falhamentos de baixo ângulo ou subverticais, truncando e deslocando os corpos de minério por até centenas de metros.

\subsubsection{Modelo descritivo adotado}

Os depósitos tipo Perau, como vistos na bibliografia, apresentam as seguintes características gerais:

- morfologia estratiforme com grande extensão lateral;

- capeamento de barita e formação ferrífera bandada;

- litologias encaixantes de origem sedimentar marinha;

- presença de rochas conglomeráticas, vulcanoclásticas e xistos carbonosos;

- presença de rochas ígneas intrusivas;

- mineralogia contendo galena, pirita, esfalerita, pirrotita e calcopirita;

- zoneamento químico vertical e horizontal.

Admite-se, neste trabalho, a classificação de Daitx (1996) que associa as mineralizações tipo Perau ao tipo sedimentar exalativo (sedex).

As mineralizações estratiformes tipo Perau, possivelmente, ocorreram num ambiente marinho, próximo à borda da bacia. $A$ alternância da mineralização com as encaixantes indica uma origem singenética. A presença de rochas 
conglomeráticas indica possível atividade tectônica contemporânea à sedimentação das rochas encaixantes. Devido à presença de rochas ígneas intrusivas e rochas vulcanoclásticas conclui-se que a área, provavelmente, tinha um fluxo térmico anormal, propiciando a energia para o sistema hidrotermal exalativo. Resumidamente trata-se de uma mineralização formada a partir de processos exalativos instalados no fundo de bacias de origem tectônica. Processos tectônicos sinsedimentares, possivelmente, possibilitaram a abertura de espaços onde os fluidos circularam e por onde as soluções mineralizantes chegaram ao assoalho marinho depositando os sulfetos metálicos.

Para a definição dos parâmetros de prospecção das mineralizações tipo Perau consideraram-se os dados levantados na bibliografia, com ênfase nos fatores condicionantes da mineralização, observados nas minas e depósitos da área. Também foram considerados aqueles fatores derivados dos diversos modelos genéticos apresentados na bibliografia. Estes parâmetros são apresentados a seguir:

- estratigraficamente, verificam-se que as ocorrências minerais estão associadas à Formação Perau, mais especificamente à seqüência carbonática/pelítico-carbonática (Daitx, 1996). O contato entre os quartzitos e os pelitos da Formação Perau deve ser considerado como um guia prospectivo importante. Além disso é possivel estender o fator estratigráfico a niveis correlacionáveis à Formação Perau, presentes na região, como o Subgrupo Ribeira;

- litologicamente consideram-se mais favoráveis às mineralizações as rochas carbonáticas, como carbonato xistos com intercalaçöes de mármores e também os dolomitos, e as litologias compostas pela alternância de mármores dolomíticos e mica xistos. Xistos, filitos e rochas metabásicas também são consideradas, mas com menor importância. As rochas metabásicas são utilizadas como referência às fontes de calor no processo hidrotermal; os xistos e filitos podem caracterizar o ambiente marinho;

- uma característica e guia prospectivo importante deste tipo de mineralização são as formações ferríferas bandadas e níveis baritíferos que, em geral, capeiam o nivel mineralizado estratiforme; 
- é preferível a prospecção visando depósitos integrados de chumbo, zinco e cobre, neste caso, devido à possibilidade de viabilidade econômica ser maior. Deste modo, os dados geoquímicos de sedimentos de corrente, onde as anomalias de chumbo, zinco e cobre se referem a uma mesma bacia, são relativamente mais importantes que anomalias isoladas.

- embora o controle estrutural não seja preponderante neste tipo de mineralização, os principais depósitos situam-se nas proximidades de grandes falhamentos, como o Ribeirão Grande (Daitx, 1996), e estão alinhados numa direção NE-SW. Além disso, as características das rochas encaixantes indicam possivelmente um ambiente de bacias de origem tectônica controladas por falhamentos; em termos de controle estrutural considera-se a possibilidade, embora remota, de uma zona de stockwork a qual poderia ter se instalado em área de fraqueza crustal, fraturada. De maneira geral considerase o controle estrutural, na mineralização tipo Perau, como um fator acessório, de maneira que não é um fator com peso considerável.

\subsubsection{Parâmetros de prospecção para depósitos tipo Perau aplicados em geoprocessamento}

$\mathrm{Na}$ aplicação dos parâmetros prospectivos, definidos para as mineralizações tipo Perau, alguns elementos fatuais não puderam ser utilizados, devido a incompatibilidade da escala de estudo utilizada em relação à escala de trabalho necessária para a deteç̧ão destes elementos. Como exemplo, pode-se citar a não utilização dos níveis baritíferos e formações ferríferas, que capeiam a mineralização, como guias prospectivos aplicáveis em geoprocessamento.

Baseando-se nos parâmetros definidos, anteriormente, para direcionar a prospecção regional de sulfetos maciços tipo Perau, são apresentados a seguir os parâmetros utilizados na determinação de áreas favoráveis à mineralização utilizando-se técnicas de geoprocessamento.

Foram considerados quatro fatores principais, os quais são denominados:

- Fator litológico

- Fator estratigráfico

- Fator geoquímico 
- Fator estrutural

O fator litológico é composto pelas seguintes litologias:

Tabela 1: Fator litológico - Perau

\begin{tabular}{|c|c|}
\hline Código & Descriçăo da litologia \\
\hline CS & Carbonato xistos com intercalações de mármores \\
\hline $\mathrm{MX}$ & Alternância de mármores dolomíticos e micaxistos com tremolita \\
\hline$x$ & xistos com intercalações de quartzitos; AS/AF - metarritmitos e metargilitos \\
\hline B & Metavulcânicas básicas e ácidas (fator térmico) \\
\hline \multicolumn{2}{|c|}{ As abreviaturas correspondem aos códigos utilizados no mapa geológico em } \\
\hline \multicolumn{2}{|c|}{ O Fator estratigráfico é composto das seguintes unidades: } \\
\hline Código & Descrição da litologia \\
\hline $\mathrm{vp}$ & Formação Perau \\
\hline \multirow[t]{2}{*}{$v$} & Subgrupo Ribeira \\
\hline & Contato quartzitos - pelitos na Formação Perau \\
\hline
\end{tabular}

O fator geoquímico é composto das seguintes anomalias:

Tabela 3: Fator geoquímico - Perau

$\mathrm{Pb}$

$\mathrm{Cu}$

$\mathrm{Zn}$

O Fator estrutural é composto dos seguintes elementos:

Tabela 4: Fator estrutural - Perau

Lineamentos - falhas

Lineamentos magnéticos

Zonas de fraqueza estrutural - áreas de máxima isofreqüência de fraturamento

Áreas de falha e fraturamento 


\subsubsection{Tipo Panelas}

\subsubsection{Observações genéticas e descritivas gerais}

As mineralizações tipo Panelas correspondem a depósitos compostos por sulfetos filonares encaixados em rochas carbonáticas; não há ainda uma caracterização precisa sobre a origem dos fluidos hidrotermais que geraram estas mineralizações. Alguns autores definem estas mineralizações como epigenéticas remobilizadas, depositadas nos carbonatos, a partir de um estoque metálico prévio contido nos sedimentos e carbonatos (Damasceno, 1967; Fleischer, 1976; Odan et al., 1978; R.B. Silva et al., 1982 entre outros). Outro aspecto descrito na bibliografia é o da restrição da ocorrência das mineralizações a um determinado nível estratigráfico definindo as mineralizações tipo Panelas como possivelmente strata-bound em termos regionais (Barbour et al., 1988 e 1990). Deste modo, descreve-se o tipo como mineralização de sulfetos de origem hidrotermal em carbonatos restritos a um determinado horizonte estratigráfico (strata-bound).

O termo hidrotermal significa água quente, e água quente pode ser originada por outros processos diferentes dos magmáticos. Podem ser processos meteóricos, ou conatos, ou processos de liberação de água de minerais durante $\circ$ metamorfismo (Jensen \& Bateman, 1981).

Segundo Pirajno (1992) um sistema hidrotermal pode ser definido como uma distribuição de fluidos quentes, circulando, lateralmente e verticalmente, a várias temperturas e pressões, sob a superficie terrestre. Uma mineralização hidrotermal é formada pela circulação de fluidos, com temperaturas de $50^{\circ}$ a mais de $500{ }^{\circ} \mathrm{C}$, que lixiviam, transportam e posteriormente precipitam seu conteúdo metálico em resposta a uma mudança nas condições físico-químicas. As rochas, nas quais o depósito é formado sofrem uma grande variação na gradação da intensidade de alteração hidrotermal que diminui com o aumento da distância das rochas em relação à fonte dos fluidos. A alteração ocorre devido à instabilidade mineral das rochas na presença dos fluidos hidrotermais. Os novos minerais são formados durante o processo de reequilíbrio do sistema. 
Segundo Jensen \& Bateman (1981), os depósitos que produzem reações fracas com a rocha hospedeira ou são formados por soluções que migraram a partir de uma rocha intrusiva distante ou não são derivados de qualquer rocha intrusiva.

Evans (1992) afirma que há pouca dúvida de que a maioria dos depósitos desta classe (depósitos de chumbo-zinco hospedados em carbonatos/epigenético) tenham sido formados a partir de soluções hidrotermais. Segundo Evans (1992), a definição da fonte destas soluções e seus constituintes metálicos é muito problemática. De modo geral, não há uma associação direta com intrusões ígneas que poderiam explicar a origem das fontes de fluidos.

Pirajno (1992) descreve as principais feições das mineralizações de metais básicos hospedadas em carbonatos. Entre estas feições destacam-se as seguintes: (1) ocorrem em rochas calcárias e dolomíticas; (2) a mineralização é geralmente strata-bound em filões; (3) os principais minerais são galena, esfalerita, pirita, marcassita e calcopirita, e os minerais de ganga são dolomita, calcita, fluorita, barita e quartzo; (5) não são associadas a rochas ígneas.

Segundo Pirajno (1992) na prospecção de sulfetos metálicos hospedados em carbonatos vários fatores devem ser considerados, tais como a ausência de atividade ígnea, a presença de hidrocarbonetos e/ou evaporitos, e o fato de que o minério, geralmente, ocorre na borda de uma bacia ou nos flancos de domos dentro da bacia. A fotointerpretação, em conjunto com a checagem de campo, busca selecionar áreas onde ocorrem falhamentos, lineamentos e outras estruturas de fraqueza que podem ter controlado a evolução da bacia ou ainda ter possibilitado maior permeabilidade.

\subsubsection{Observações genéticas e descritivas - casos no Vale do Ribeira}

Oliveira (1937) descreve a ocorrência de "Panellas de Brejaúvas" como um afloramento em calcário, constituido por limonita com galena argentifera e pirita. O autor comenta as intrusões graníticas nos calcários e atribui a ocorrência na região de "vieiros metallíferos" (filões mineralizados) aos granitos.

Knecht (1938) atribui aos granitos a fonte dos fluidos hidrotermais metalíferos, que propiciaram as mineralizações de chumbo nos calcários. $O$ autor 
cita as seguintes ocorrências: Santo Antônio de Itaoca, Pinheiros, Braço da Pescaria, Taquarussu, Barra das Criminosas e Itapirapuã.

Segundo Barbosa \& Guimarães (1946), a primeira menção de chumbo no Vale do Ribeira data de 1858, quando o governo Imperial deu permissão ao Eng. ${ }^{\circ}$ Luiz d'Ordan para explorar chumbo no município de Iporanga.

Barbosa \& Guimarães (1946) descrevem as ocorrências de minério de chumbo no Vale do Ribeira conhecidas na época. Os autores concluem que há correlação entre as mineralizações e os granitos, e descrevem que as cúpulas dos granitos configuram-se como áreas de interesse para prospecção. Contudo, definem que as áreas de maior possibilidade de mineralização são aquelas representadas pelos calcários. Os autores definem a "Província metalogenética do Vale do Ribeira", a partir de todas as jazidas na região, como filiadas ao "magma granítico" e de idade Pré-Cambriana.

Bastian (1946), ao descrever as ocorrências conhecidas de chumbo no Lajeado, conclui que as mineralizações são do tipo epigenético, ou seja, formadas a partir de fluidos mineralizantes, relacionados ao magma granítico.

Barbosa (1955) admite a hipótese das soluções hidrotermais ascendentes como responsáveis pela mineralização da Mina de Furnas. Segundo este autor, a encaixante da jazida de Furnas é formada por uma camada de calcário marmorizado e as mineralizações parecem estar associadas às fraturas. Os xistos presentes na área não contêm mineralização, entretanto estes também foram atingidos pelas fraturas.

Segundo Barbosa (1955), as soluções mineralizantes devem ter tido filiação magmática, embora o mesmo autor afirme que não se conheçam rochas ígneas nas adjacências da mina, a não ser diques de diabásio. Os granitos afloram a alguns quilômetros da mina. Segundo o autor, as jazidas têm distribuição regional e o magma responsável deve ter tido também uma grande extensão.

Damasceno (1967) descreve a geologia da Mina do Paqueiro e entre os controles da mineralização cita como controle litológico: "...calcários escuros, bastante impuros...", e como controle estrutural: "...as fraturas de direção N60E, discordantes da estratificação dos calcários encaixantes, onde se alojaram os filões e que serviram de conduto às soluções mineralizantes.". 
O autor atribui os espaços vazios, onde as soluções mineralizadoras percolaram, aos dobramentos regionais anteriores à mineralização. $O$ autor também cita a proximidade dos filöes do Paqueiro a uma pequena estrutura anticlinal.

Ainda segundo Damasceno (1967), o sistema de fraturas orientado predominantemente N40W teve importância nas mineralizações de Furnas e Panelas, o que não acontece no Paqueiro.

Damasceno (1967) calcula a idade dos granitos na região (coletado em Itapirapuã, $\mathrm{km} 339,5$ da rodovia SP-44, entre Apiaí e Ribeira) pelo método $\mathrm{Pb} / \mathrm{Pb}$, em uma idade modelo de $510 \mathrm{Ma}$., o filito coletado na estrada do Ribeirão do Rocha forneceu idade KJAr de $580 \mathrm{Ma}$., interpretado por Damasceno (1967), como a idade do último evento metamórfico. Damasceno (1967) calculou as idades $\mathrm{Pb} / \mathrm{Pb}$ das mineralizações do Paqueiro, Furnas, Rocha e Bassetti, como da ordem de $1.100 \mathrm{Ma}$. Deste modo, o autor concluiu que não há sustentação para a hipótese de derivação hidrotermal das mineralizações a partir das intrusões graníticas. Considera, então, as seguintes possibilidades para explicar as mineralizações na região:

1. deposição singenética (sedimentos do Supergrupo Açungui), posterior remobilização e concentração de chumbo.

2. derivação das mineralizações de uma fonte desconhecida, talvez no embasamento ou na parte inferior do pacote metassedimentar (Supergrupo Açungui)

A hipótese 1, de Damasceno (1967), é detalhada na seguinte seqüência de eventos:

- deposição dos sedimentos do Supergrupo Açungui contendo traços de chumbo

- metamorfismo e intrusão dos granitos

- remobilização e concentração do chumbo

Melcher (1968), em trabalho que abrangeu todo o distrito mineral do Ribeira de Iguape, também comenta a possivel contribuição das intrusões graníticas nas mineralizações. O autor observa que as ocorrências minerais no Distrito Mineral do Ribeira de Iguape agrupam-se numa área de forma lenticular, com largura 
máxima de $20 \mathrm{~km}$ e extensão aproximada de $80 \mathrm{~km}$. O alongamento maior desta área corresponde à direção regional das estruturas. Alguns depósitos (Itapirapuã, Mato Seco, Criminosas e Córrego Seco) situam-se em pequenos enclaves de metassedimentos carbonáticos nos granitos. O afloramento denominado Onças é o único cujas encaixantes são constituídas por xistos. Todas as jazidas estão encaixadas em calcários. Melcher (1968) descreve que os depósitos se alinham sobre algumas poucas faixas calcárias preferenciais. Melcher (1968) conclui que a presença de formações carbonáticas foi essencial para a deposição da carga das soluções hidrotermais, embora outros fatores metalogenéticos também tenham contribuído para determinar a posição dos agrupamentos de ocorrências e a localização exata de cada veio. $O$ autor observa que nenhuma ocorrência mineral está afastada mais de $7 \mathrm{~km}$ de um corpo granítico.

Fleischer (1976), em trabalho que abrangeu as mineralizações de chumbo conhecidas no Brasil, foi o primeiro autor a definir as mineralizações filonares sulfetadas em carbonatos do Supergrupo Açungui como "tipo Panelas". O autor descreve a mineralização em termos gerais como: "Mineralização plumbo-argentifera filoniana em calcários de idade Pré-Cambriana Superior por remobilização de um estoque metálico préexistente devido a diferentes processos mobilizadores", e também cita a mineralização do Rocha quando descreve esta tipologia.

Bettencourt et al. (1976), em trabalho de contribuição à metalogenia do sistema de Dobramentos Ribeira, confirmam a distribuição das mineralizações numa faixa lenticular. Segundo os autores, estas mineralizações não se afastam mais do que uma dezena de quilometros de corpos graníticos, contudo não se sustenta a hipótese de derivação das mineralizações em relação aos granitos, devido à idade das galenas (Damasceno, 1970 e Cassedane, 1972) ser em torno de $1.100 \mathrm{Ma}$., enquanto os granitos têm idades de $620 \mathrm{Ma}$. a $540 \mathrm{Ma}$.

Odan et al. (1978) descrevem a geologia local da mina de Panelas, assim como a mineralização, além de uma possivel interpretação genética. Segundo estes autores, a mina está numa estrutura sinclinal de direção N60E truncada pelo granito Itaoca. O pacote sedimentar que ocorre na área é composto por dois horizontes calcários separados por sericita xistos. O nível mineralizado corresponde ao calcário inferior. Segundo Odan et al. (1978) a mineralização é atravessada por corpos de granito; além disso, o batólito granítico Itaoca está 
presente na área mineralizada. Embora, em geral, a mineralização seja concordante com o acamamento do calcário, existem corpos mineralizados discordantes.

No trabalho de Odan et al. (1978) destaca-se a apresentação da interpretação genética que defende a hipótese plutonista da mineralização de Panelas (mineralização derivada de soluções mineralizantes originárias da diferenciação magmática, depositada por metassomatismo nos calcários reativos). Os autores apresentam as limitações dessa interpretação, quando a confrontam com o contexto de outras mineralizações na região, como Rocha, Barrinha, Furnas, Lajeado, etc. Argumentos favoráveis à hipótese plutonista apresentados por Odan et al. (1978):

"...O fato dela ocorrer nas proximidades de uma intrusiva; o de preencher fraturas discordantes e mesmo ortogonais ao acamamento; o de se conformar frequentemente a corpos intrusivos; o de que justamente a zona $\mathrm{A}$, mais próxima do batólito e atravessada por inúmeros pequenos corpos intrusivos seja a mais ricamente mineralizada, são todos argumentos sugerindo fortemente que soluções mineralizantes derivadas de diferenciação magmática depositaram seu conteúdo metálico por metassomatismo dos calcário reativos."

Odan et al. (1978) discutem a relação deste caso com as mineralizações na área (Mina do Rocha, Barrinha, Furnas e Lajeado entre outras). Em todas essas mineralizações a rocha encaixante é o calcário. Os autores comentam que, em cada uma dessas mineralizações, há feições particulares, e enumeram as seguintes caracteristicas:

- Rocha - filões transversais ao acamamento preenchendo fraturas;

- Barrinha - mineralização ocupando a charneira de uma anticlinal;

- Furnas - corpos inclinados em forma de charutos;

- Lajeado - charutos horizontais.

Segundo os autores, em nenhum destes depósitos a mineralização está relacionada a uma intrusão granítica, ou a uma auréola de metamorfismo de contato. Afirmam que o controle destas mineralizações é estrutural, sendo que os calcários continham um estoque metálico que foi remobilizado.

Desta forma, em Panelas, segundo Odan et al. (1978), é lógico considerar os metais como constituintes originais do sedimento, onde a deformação que gerou a estrutura sinclinal propiciou uma primeira concentração e, com as intrusões graniticas, houve redistribuição das mineralizações. 
Chiodi et al. (1982) discutem a geologia e as mineralizações das minas do Rocha, Paqueiro e Barrinha, além de outras, na região destas minas. Os autores consideram a existência, na região, de três faixas definidas nas rochas carbonáticas, ao longo das quais se concentra a quase totalidade das mineralizações de chumbo conhecidas.

Estas faixas foram denominadas noroeste, central e sudeste. A faixa noroeste inclui, de SW para NE, as mineralizações da mina do Rocha (Fundãozinho, São Francisco, Basseti, Egara, Esperança, Matão, Matão I, Matão II, Matão III, e Matão IV), Pedra do Morcego, Onça II e Quarenta Oitavas. A faixa central engloba as ocorrências do Paqueiro, Pessegueiro, Bueno, Córrego do Eduardo e Diogo Lopes. A faixa sudeste contém as mineralizações da mina da Barrinha (locais Oito, Quatro e São Joaquim), Braz-Carumbé, Cecrisa, Costão, Laranjal, Barra Grande e Panelas. Segundo estes autores, em geral, estas mineralizações são filonares e ocupam planos de fraturamento em rochas carbonáticas.

Chiodi et al. (1982) apresentam como principais controles lito-estruturais destas mineralizações as rochas carbonáticas, ocupando sistemas preferenciais de fraturamento (mineralizações do Rocha), associando-se a zonas de falha (mineralizações do Paqueiro) e alinhando-se ao longo de contato tectônico entre rochas carbonáticas e terrígenas (mineralizações do Bueno, Diogo Lopes e Córrego do Eduardo) ou ainda em zona de falha de cavalgamento, disposta plano-axialmente às dobras (mineralização da Barrinha, local Quatro). Segundo os autores, na seqüência carbonática, a associação das mineralizações aos tipos dolomíticos quartzosos está relacionada à maior competência destas rochas, que permite a abertura de espaços pelo fraturamento, criando condições para deposição das soluções mineralizantes. Já as rochas carbonáticas calcíticas sofrem deformação plástica e não apresentam fraturamento. 


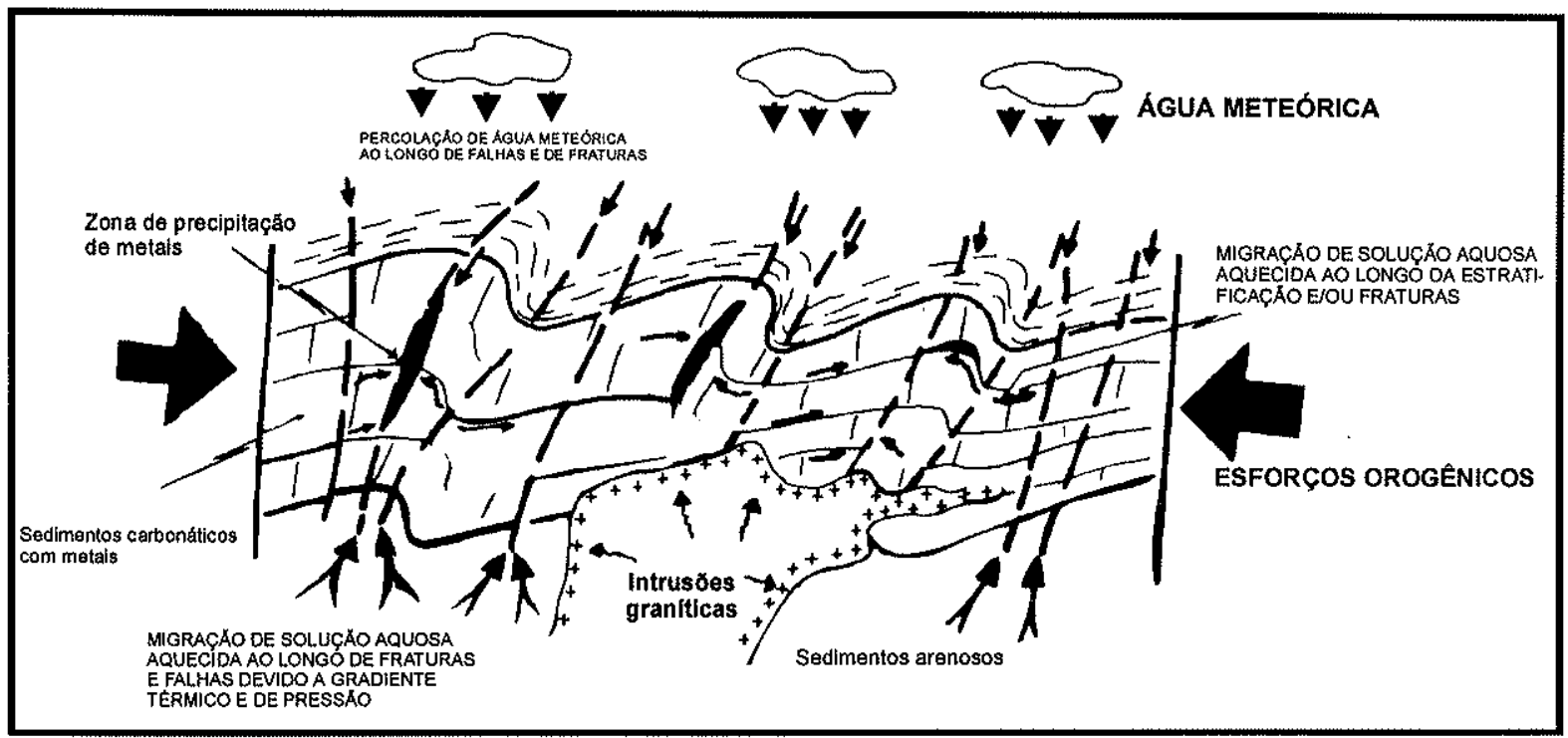

Modificado de R.B. Silva et al., 1982

Figura 5: Modelo genético interpretativo das mineralizações epigenéticas de chumbo do Vale do Ribeira

R.B. Silva et al. (1982) definem as características comuns destas mineralizações filonares como basicamente de sulfetos e óxidos de $\mathrm{Pb}, \mathrm{Zn}, \mathrm{Ag}$ e $\mathrm{Cu}$, preenchendo zonas de falhas ou fraturas em calcários escuros (vide figura 5). Segundo os autores, esse tipo de mineralização é responsável por cerca de 74 indícios e ocorrências de $\mathrm{Pb}, \mathrm{Zn}$ e Ag no distrito mineral do Vale do Ribeira, no Estado de São Paulo, englobando o jazimento de Furnas e as antigas lavras de Lajeado e Espirito Santo.

R.B. Silva et al. (1982) defendem que a fonte dos metais básicos para as mineralizações filonares não está relacionada exclusivamente aos granitos, mas provavelmente relaciona-se à presença dos metais nos metassedimentos. Entendem, desta maneira, as mineralizaçōes como epigenéticas, com remobilização e concentração dos metais contidos nos metassedimentos do Supergrupo Açungui para zonas fraturadas e remobilização motivada pela interação entre orogênese, intrusões graníticas e águas meteóricas e conatas, que geram condições suficientes para a formação de soluções hidrotermais. Entre os fatos que justificam este pensamento, segundo R.B. Silva et al. (1982), destacam-se:

- presença de mineralizações singenéticas mais antigas em metassedimentos da região como no Perau; 
- idade de $500 \mathrm{Ma}(\mathrm{K} / \mathrm{Ar})$, indicando a idade mínima do metamorfismo ou evento termal, para os granitos e idade modelo de $1.130 \mathrm{Ma}(\mathrm{Pb} / \mathrm{Pb})$ para o Chumbo (mineralização), de modo que os granitos não foram a fonte do chumbo;

- o fato das mineralizações estarem, em geral, sempre próximas às intrusivas graníticas e hospedadas em rochas carbonáticas, reforça o pensamento de que os leitos carbonáticos realmente são os portadores dos metais que foram posteriormente remobilizados;

Os autores (R.B. Silva, et al., 1982) analisam os resultados da dosagem por absorção atômica de $\mathbf{4 0}$ amostras de rochas carbonáticas na área da Mina de Furnas. Os resultados apresentam um enriquecimento em $\mathrm{Pb}$ e $\mathrm{Zn}$, de vários níveis de calcários da área, em relação ao clarke mundial. Os autores concluem que este enriquecimento está relacionado com o teor de argila e matéria orgânica, como observado por Odan et al. (1978), nas fácies mais escuras do calcário, na área da mineralização de Panelas.

Em estudo da mineralização da Barrinha, Barbour et al. (1984) observam que as três mineralizações da área (Mina Quatro, Cito e São Joaquim) localizamse no topo da seqüência carbonática. Na área, a geologia, descrita em escala regional, é composta por seqüência carbonática inferior e seqüência terrígena superior. Segundo Barbour et al. (1984), as faixas calcárias aflorantes estão relacionadas às zonas axiais de anticlinais, que foram submetidas a esforços ao longo de seus eixos, provocando ondulação, redobramento, deslocamentos horizontais ao longo das falhas formadas em fase anterior, assim como, deformações locais que afetaram seletivamente o comportamento tectônico dos niveis sulfetados sinsedimentares.

Entre as características genéticas da mineralização estratiforme da Barrinha, citadas por Barbour et al. (1984), são destacadas as seguintes:

- associação direta dos níveis sulfetados com os dolomitos portadores de ankerita;

- condições euxínicas locais da bacia de deposição, ressaltadas pela presença de carbonatos ( $\mathrm{Ca}, \mathrm{Mg}$ e $\mathrm{Fe}$ ), sulfetos ( $\mathrm{Fe}, \mathrm{Pb}, \mathrm{Cu}$ e $\mathrm{Zn}$ ) e matéria orgânica; 
- Nucleação e associação dos sulfetos básicos com os niveis representados pelas fácies sulfeto (pirita) e carbonato (ankerita) de formações ferriferas sedimentares;

- pequena dimensão da bacia de deposição dos sulfetos, representando um sítio morfológico de dimensão máxima de algumas centenas de metros, propício à nucleação dos sulfetos básicos;

Barbour et al. (1984) recompõem as fácies sedimentares da Barrinha como pequenas bacias portadoras de camadas ou lentes de sulfetos sinsedimentares, alternadas com sedimentos pelito-carbonáticos.

Barbour et al. (1988) definem os traços gerais do modelo Panelas, e descrevem esses traços como pertencentes ao nível estratigráfico Panelas da seguinte maneira:

- "Como regra geral os corpos são strata-bound, limitando-se, mesmo em suas mineralizações epigenéticas, à rocha carbonática. Em caráter mais local as mineralizações configuram corpos estratiformes."

- "Lentes predominantemente concordantes com as encaixantes (Barrinha, Laranjal, Cecrisa e Costão)."

- "Lentes e veios concordantes e representativamente discordantes (Rocha, Paqueiro, Pessegueiro, Bueno, Córrego do Eduardo, Diogo Lopes, Panelas, Furnas e Lajeado), definindo claramente corpos epigenéticos."

- "Leitos carbonáticos enriquecidos singeneticamente em metais base em valores acima do background, a exemplo de Panelas e Furnas."

- "As áreas de fechamento de veios concordantes e discordantes exibem incremento de pirita seguido de calcita fina a grosseiramente cristalizada. Exemplo na jazida de Panelas e Furnas."

- "Alteração de paredes em veios que preenchem fraturas, exibindo silicificação comum e sericitização e dolomitização raras. Exemplos nas jazidas de Furnas, Rocha e Paqueiro. “

- Mineralizações intensas nas proximidades do contato de metacalcários capeados por filitos ou sericita-xistos. Exemplo do Rocha, Lajeado, Paqueiro e Bueno."

- Definição genética/tectônica: em seus traços gerais é um nível singenético com superimposição predominantemente de processos epigenéticos tectono-hidrotermais."

Barbour et al. (1990) apresentam, novamente, as características principais das mineralizações tipo Panelas, entre elas são destacadas as seguintes:

- corpos strata-bound limitando-se as rochas carbonáticas;

- lentes concordantes com as encaixantes no caso das mineralizações da Barrinha, Laranjal, Cecrisa e Costão; 
- lentes e veios concordantes e representativamente discordantes definindo corpos epigenéticos nas mineralizações do Rocha, Paqueiro, Pessegueiro, Bueno, Córrego do Eduardo, Diogo Lopes, Panelas, Furnas e Lajeado;

- leitos carbonáticos enriquecidos singeneticamente em metais básicos com valores acima do background, a exemplo de Panelas;

- mineralização em zona de brechação

- mineralizações intensas nas proximidades e no contato, às vezes tectônico, de metacalcários capeados por filitos ou sericita xistos. Exemplos do Rocha, Lajeado, Paqueiro, Bueno, Córrego do Eduardo, Diogo Lopes e Onça.

Entre as conclusões apresentadas por Barbour et al. (1990), destaca-se a justificativa das diferenças entre as mineralizações tipo Panelas, devido aos processos de litificação/diagênese superimpostos a um único processo genético primário. Barbour et al. (1990) definem o tipo Panelas como uma mineralização do tipo singenético com superimposição de processos epigenéticos tectono/hidrotermais. Além disso, os autores defendem as condições de deposição extensiva dos sulfetos, em um ambiente tectonicamente ativo, formado por um sistema exalativo sedimentar sindeposicional.

Tassinari et al. (1990), segundo um estudo isotópico de $\mathrm{Pb}$ e $\mathrm{Sr}$ nas mineralizações tipo Panelas, concluem que a origem das soluções mineralizantes é claramente crustal, sendo elas formadas por processos de remobilização a partir de fontes crustais diversas, provocados por ação dos eventos metamórficos regionais entre 1,4 e 1,1 $\mathrm{Ba}$.

Hasui et al. (1992) descrevem as famílias de juntas no interior da mina de Furnas e destacam que todas têm altos mergulhos. Os autores descrevem os corpos de minério como charutos de extensão decamétrica alojados na intersecção das fraturas com o pacote carbonático, e estas fraturas são descritas em duas famílias, uma de direção NE-SW e outra NW-SE as quais se configuram como famílias de partição. Segundo Hasui et al. (1992) esta descrição corrobora a qualificação distensiva dada às juntas, e indica que a mineralização (tipo filonar) foi tardia no processo de deformação. 
Daitx et al. (1995), em estudo da gênese da jazida de Furnas, fazem a caracterização desta mineralização como hidrotermal a partir dos seguintes parâmetros:

- "posicionamento estrutural discordante dos corpos sulfetados em relação às rochas carbonáticas encaixantes, mostrando a natureza epigenética da mineralização

- existência de halos de alteração hidrotermal nas rochas encaixantes, marcados por mudanças químicas e mineralógicas, ao longo das paredes dos filōes e junto a vênulas, evidenciando a interação dos fluidos mineralizadores com as rochas carbonáticas;

- o zoneamento dos filðes sulfetados, resultado da interação entre o fluido mineralizador e as rochas encaixantes;

- o estabelecimento de uma temperatura máxima de $350^{\circ} \mathrm{C}$ para a cristalização da paragênese (pirita* arsenopirita), com base no conteúdo atômico de arsênio da arsenopirita;

- os valores das razões $\mathrm{Co} / \mathrm{Ni}$ em piritas, similares ao de outras jazidas hidrotermais; e,

- a composição dos fluidos presentes em inclusões no quartzo e esfalerita associados à mineralização, indicando a presença de $\mathrm{H}_{2} \mathrm{O}, \mathrm{CO}_{2}, \mathrm{CH}_{4}$ e de íons de $\mathrm{Na}, \mathrm{Ca}, \mathrm{Mg}$ e/ou $\mathrm{Fe}$."

Daitx et al. (1995) não definem a origem do fluido hidrotermal responsável pela formação das mineralizações sulfetadas; contudo, segundo os autores, os dados isotópicos, embora inconclusivos, apontam para uma interação com as rochas carbonáticas e não excluem ou favorecem a origem magmática. Descrevem ainda que a disposição dos filões ao longo de estruturas geradas durante o principal evento tectono-metamórfico que atingiu a região, coloca as mineralizações como formadas na fase tardia deste episódio, sugerindo que os fluidos mineralizadores possam ter se gerado por desidratação e descarbonatação metamórfica das porções profundas da pilha metassedimentar, particularmente de seus pacotes clásticos.

A classificação da jazida de Furnas segundo Daitx et al. (1995) é a de um depósito hidrotermal de média temperatura $\left(350^{\circ} \mathrm{C}\right)$, de origem metamorfogênica, formado a partir de soluções salinas levemente ácidas e oxidantes.

\subsubsection{Modelo descritivo adotado}

Os dados apresentados anteriormente, a respeito da tipologia e aspectos genéticos das mineralizações tipo Panelas, indicam uma grande variedade de opiniões e conclusões. As discussões estão principalmente relacionadas à origem 
dos fluidos mineralizantes, ao papel das intrusões graníticas no processo de mineralização e à origem das mineralizações: singenéticas ou epigenéticas.

As mineralizações tipo Panelas podem ser descritas, de maneira geral, segundo as seguintes caracteristicas:

- morfologia filonar;

- associação com rochas carbonáticas e rochas dolomítico-quartzosas;

- caracteristicamente strata-bound;

- mineralizações associadas aos sistemas de fraturamento, às zonas de fallha, aos contatos tectônicos entre litologias terrígenas e carbonáticas e às zonas de charneira de dobras.

Define-se a mineralização tipo Panelas como uma mineralização filonar de origem hidrotermal, mesotermal, hospedada em rochas carbonáticas. As mineralizações são predominantemente epigenéticas. Uma explicação para a origem da mineralização tipo Panelas seria a remobilização hidrotermal do conteúdo metálico contido nos sedimentos terrígenos e carbonáticos.

A definição dos parâmetros exploratórios considerou as evidências levantadas pelos trabalhos anteriores. Nesses trabalhos, estas evidências foram utilizadas como argumento na defesa das diferentes hipóteses genéticas. Entretanto, os parâmetros de prospecção não foram definidos, considerando estritamente uma única hipótese genética, lembrando-se que várias questões acerca do modelo de mineralização tipo Panelas ainda permanecem sem resposta. A definição dos parâmetros considerou tanto os elementos fatuais, quanto os elementos lógicos derivados das discussões genéticas e que, na visão deste autor, eram caracterizados pela coerência com os argumentos e evidências apresentados. Estes parâmetros são apresentados a seguir:

- fator litológico envolvendo rochas carbonáticas como dolomitos e calcários. As rochas dolomíticas configuram-se como fator importante devido a sua maior competência em relação às rochas carbonáticas, esta maior competência originou aberturas, segundo esforços tectônicos, gerando espaços vazios onde os fluidos mineralizantes percolaram e depositaram seu conteúdo metálico.

- o fator estratigráfico envolve, principalmente, as litologias carbonáticas do Subgrupo Lajeado. Contudo não se considera este fator como restritivo, mas 
sim um fator de maior peso em relação às outras unidades estratigráficas consideradas como a Formação Itaiacoca e a Formação Água Clara.

- o fator geoquímico envolve anomalias de chumbo, zinco e cobre, definidas a partir de levantamentos geoquímicos regionais de sedimento de corrente. As anomalias conjuntas de $\mathrm{Pb}-\mathrm{Zn}$-Cu são consideradas como mais importantes do que as anomalias de um único elemento;

- o fator estrutural envolve lineamentos, como as falhas, e também os eixos de sinclinais e anticlinais (zonas de charneira), já que as mineralizações, por vezes, ocorrem em preenchimento de fraturas derivadas de esforços tectônicos. Neste sentido também procura-se utilizar as zonas de maior freqüência de fraturamento. Considera-se que $\circ$ fator estrutural tem importância, relativa, menor do que os outros fatores devido à escala de trabalho regional. Notou-se que estas mineralizações filonares têm forte controle estrutural; contudo isto é verificado em escala de detalhe e esta característica dificilmente pode ser extrapolada para uma escala regional com o mesmo nível de significância.

\subsubsection{Parâmetros de prospeç̧ão para depósitos tipo Panelas aplicados em geoprocessamento}

$\mathrm{Na}$ definição destes parâmetros prospectivos, consideraram-se também as características da análise feita a partir de sistemas de informação geográfica (SIG). Uma característica relevante é a necessidade de expressão espacial das informações, tanto relacionada à escala de trabalho, quanto à disposição das informações. Por exemplo, determinadas associações mineralógicas, que poderiam ser importantes no rastreamento das mineralizações, não são utilizadas devido à falta de mapeamento sistemático deste tipo de dado, assim como acontece com os controles estruturais que também ainda não foram definidos a partir de levantamentos sistemáticos.

Baseando-se nos dados apresentados e procurando as principais feições geológicas comuns às mineralizações do tipo Panelas, definem-se os principais parâmetros de prospecção regional de sulfetos filonares, tipo Panelas, considerando a utilização destes parâmetros na análise por geoprocessamento. 
De modo geral foram considerados quatro fatores principais, os quais são denominados:

- Fator litológico

- Fator estratigráfico

- Fator geoquímico

- Fator estrutural

O Fator litológico é composto das seguintes litologias:

Tabela 5: Fator litológico - Panelas

\begin{tabular}{ll}
\hline Código & Descrição da litologia \\
\hline $2 \mathrm{~m} / 4 \mathrm{~m}$ & mármores \\
$\mathrm{CS}$ & rochas cálcio-silicáticas, carbonato xistos com intercalações de mármores \\
$\mathrm{M}$ & mármores dolomíticos \\
$\mathrm{MX}$ & alternância de mármores dolomíticos e micaxistos com tremolita \\
& contato entre rochas carbonáticas $(\mathrm{M})$ e terrigenas $(\mathrm{X})$ \\
\hline
\end{tabular}

Embora alguns autores tenham citado a importância dos granitos no processo mineralizante ressaltando a proximidade dos corpos graníticos em relação às ocorrências (Melcher, 1968), os granitos não foram utilizados como um fator térmico na análise de favorabilidade. Ao se correlacionar espacialmente as ocorrências do tipo Panelas em função da distância dos granitos concluiu-se que não há correlação espacial, segundo uma análise em superfície, entre estes elementos como pode ser verificado no gráfico apresentado na figura 6.

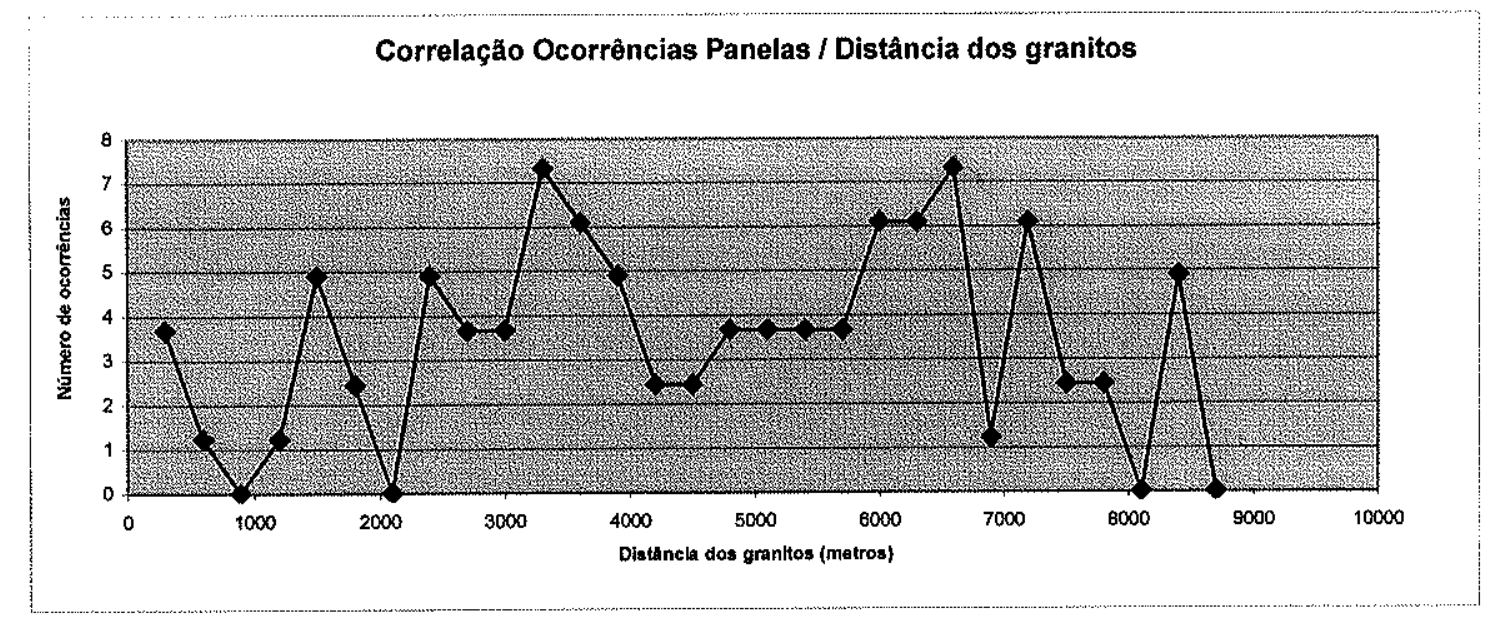

Figura 6: Correlação entre ocorrências minerais do tipo Panelas e distância dos granitos 
O Fator estratigráfico é compostos das seguintes unidades:

Tabela 6: Fator estratigráfico - Panelas

\begin{tabular}{ll}
\hline Código & Descrição da unidade estratigráfica \\
\hline $\mathrm{vl}$ & Subgrupo Lajeado \\
$\mathrm{i}$ & Grupo Itaiacoca \\
ac & Água Clara \\
\hline
\end{tabular}

O Fator geoquímico é composto das seguintes anomalias:

Tabela 7: Fator geoquímico - Panelas

$\mathrm{Pb}$

$\mathrm{Zn}$

$\mathrm{Cu}$

O Fator estrutural é composto dos seguintes elementos:

Tabela 8: Fator estrutural - Panelas

Lineamentos - eixos de dobras

Zonas de máxima freqüência de fraturamento

Lineamentos - falhas

Lineamentos magnéticos

\subsection{Análise de favorabilidade por geoprocessamento - casos de aplicação}

Apresentam-se casos de aplicação de técnicas de geoprocessamento na prospecção mineral no Vale do Ribeira.

Macedo (1996) aplicou a técnica de indices somativos (discutida nos próximos capítulos) na análise metalogenética da folhas Cerro Azul e Apiaí (1:100.000). Considerou, na análise, dois modelos de depósitos minerais, o modelo Perau e o modelo Rocha (Panelas). O autor utilizou dados geoquímicos de sedimentos de corrente, dados da geologia da área e ocorrências minerais.

Entre as limitações dos dados, o autor cita as seguintes:

- utilização das anomalias geoquímicas calculadas por Hama \& Algarte (1986) sem a utilização de outros levantamentos geoquímicos feitos na área; 
- limitações da amostragem do projeto Geoquímica no Vale do Ribeira (Morgental et al., 1978);

- não utilização de dados geofísicos;

- utilização limitada dos dados estruturais e tectônicos.

Macedo (1996) definiu os seguintes fatores para utilização na análise dos modelos Perau e Panelas (Rocha):

\section{Modelo Perau}

- fator litológico: litologias associadas a seqüências vulcânicas e sedimentares marinhas à elas associadas (metavulcânicas ácidas e básicas e rochas cálciosilicáticas);

- fator geoquímico: anomalias de $\mathrm{Cu}, \mathrm{Pb}$ e $\mathrm{Zn}$;

- fator estrutural: proximidade de falhamentos.

\section{Modelo Panelas (Rocha)}

- fator litológico: mármores, granitos e granitóides;

- fator geoquímico: anomalias de $\mathrm{Cu}, \mathrm{Pb}$ e $\mathrm{Zn}$;

- fator estrutural: proximidade de falhamentos;

- fator térmico e químico: proximidade dos contatos de granitos.

Perrotta (1996) utilizou dados geológicos, geoquímicos e de sensores remotos para estimar o potencial aurífero numa região no vale do Ribeira, nordeste da cidade de Iporanga, numa área de aproximadamente $2.800 \mathrm{~km}^{2}$.

A partir dos diversos mapas temáticos foram feitas classificações, segundo a importância da área, em relação ao modelo conceitual utilizado por Perrota (1996). Segundo o modelo de indexação de camadas (apresentado nos próximos capitulos), correlacionaram-se as ocorrências minerais, conhecidas na área de estudo, com dados em mapas temáticos, procurando-se definir os controles geológicos, assim como os controles geoquímicos e geofísicos relacionados com as mineralizações, ponderando-se as evidências; este método é também chamado de conduzido pelo modelo. Perrota também utilizou ponderadores baseados em pesos de evidência (método Bayesiano), ou seja, uma aproximação probabilistica da análise de favorabilidade na qual as probabilidades são medidas 
através de proporções entre as áreas dos mapas de evidência e as áreas das ocorrências. Segundo a autora, este método é mais objetivo pois evita a escolha subjetiva de pesos e evidências favoráveis como no modelo de índices; este método é também chamado de conduzido pelo dados (data driven).

Perrota (1996) tratou das seguinte maneira as camadas ou fatores:

- Fator litológico - gerou-se um mapa simplificado com 5 classes de favorabilidade crescente. Esta camada foi apresentada como um único nível de informação, onde foram apresentadas as litologias presentes no mapa geológico e mais as derivadas da interpretação geofísica.

- Fator geoquímico - Perrota (1996) hierarquizou os elementos correlacionados com a mineralização e gerou um mapa onde as classes foram definidas a partir da adição sucessiva dos elementos analisados. Além disso considerou as bacias não amostradas e as bacias não anômalas.

- Fator estrutural - foram analisados os mapas de isodistâncias das zonas de cisalhamento transcorrentes e falhas normais, lineamento rúptil-dúcteis e fraturas e lineamento magnéticos. A partir da correlação das ocorrências com estes corredores separaram-se as classes de maior importância.

Rostirolla (1997) discute aspectos da avaliação de favorabilidade numa área no Vale do Ribeira, numa seqüência que compreende a Formação Itaiacoca. As evidências utilizadas nestes trabalho foram tratadas utilizando-se lógica booleana. A partir do modelo do depósito, o autor definiu os ponderadores com base na freqüência de ocorrência entre as evidências e os depósitos conhecidos, para isso, o autor aplica a ponderação Bayesiana (ponderação baseada em probabilidade) e a ponderação multivariada (baseada na análise de principais componentes).

O autor apresenta os seguintes metalotectos na definição da favorabilidade de $\mathrm{Pb}-\mathrm{Zn}$ :

- falhas de cavalgamento, falhas de empurrão e transcorrentes;

- mármores basais da Fm. Itaiacoca;

- proximidade do contato tectônico entre o complexo pelito-carbonático da Fm. Itaiacoca e xistos do Grupo Setuva.

São apresentadas as seguintes variáveis utilizadas na ponderação:

- mapa de depósitos e ocorrências; 
- estruturas da fase de cavalgamento;

- falhas da fase de empurrão;

- lentes carbonática com metadolarenitos;

- metapelitos com intervalos carbonosos;

- mapa aerogeofísico canal Contagem Total;

- superfície de tendência de $3^{a}$ ordem dos dados geoquímicos de solo.

Braghin (1998) aplica técnicas de análise metalogenética por geoprocessamento utilizando as lógicas booleana e fuzzy (discutidas nos próximos capítulos). $\mathrm{O}$ autor definiu um modelo prospectivo para mineralizações de chumbo e cobre em uma área de estudo no Vale do Ribeira (Folha Pilar do Sul, SF-23-Y-C-IV-4) com as seguintes características:

- rochas pertencentes ao grupo Açungui;

- áreas representativas de anomalias geoquímicas para $\mathrm{Cu}$ e $\mathrm{Pb}$;

- áreas que tenham alguma caracterização radiométrica indicativa de hidrotermalismo correspondentes às rochas de interesse com altos valores de $\mathrm{KeU}$;

- áreas com pouca susceptibilidade magnética. 


\section{MATERIAIS E MÉTODOS}

A metodologia utilizada baseou-se no desenvolvimento de modelos de prospecção aplicáveis segundo um banco de dados espaciais digitais e técnicas de geoprocessamento. A base dessa metodologia é a ponderação dos parâmetros de prospecção, segundo sua importância relativa e absoluta, de modo que a associação espacial destes parâmetros reflita as opiniões de peritos acerca da possibilidade de uma determinada área conter mineralização.

A definição e a ponderação dos parâmetros prospectivos são baseadas nos modelos genéticos, aplicáveis à área de estudo e ao bem mineral de interesse, além disso, envolvem parâmetros fatuais que são exclusivamente baseados nas observações analíticas e de campo.

\subsection{Sistemas de Informação Geográfica}

\subsubsection{Definições}

São definidos alguns termos utilizados neste trabalho visando justificar aspectos da metodologia relacionados a análise dos dados e mostrar a necessidade de utilização destas metodologias na definição de mapas de favorabilidade. Entre os termos apresentados e discutidos estão: sistema de informação geográfica, geoprocessamento e sistemas especialistas.

Segundo Maguire et al. (1993), entre as dificuldades apresentadas na definição do que é um sistema de informação geográfica (SIG) relacionam-se as seguintes: trata-se de tecnologia recente, deste modo, falta debate acadêmico na definição do enfoque central das atividades envolvidas em um SIG, além disso, a diversidade de aplicações dificulta a definição exata do que trata um SIG.

Para Maguire et al. (1993), estritamente, um SIG inclui tanto um sistema de informação baseado em computador, quanto um sistema manual. Segundo os autores, na definição de um SIG pode-se enfatizar o elemento geográfico. A utilização deste elemento define a diferença básica entre um SIG e outros sistemas de informação. Os termos georreferenciado, geográfico e espacial são 
freqüentemente utilizados, de maneira intercambiável, para se referir a elementos geográficos.

Busca-se a definição de SIG com ênfase no aspecto espacial das informações, em detrimento de outros aspectos, muito importantes, mas não fundamentais. Entre estes outros aspectos, cita-se: o banco de dados, a manipulação e análise dos dados e o suporte à decisão.

Segundo Aronoff (1989), um SIG é qualquer conjunto de procedimentos, manuais ou baseados em computador, utilizados para guardar e manipular dados referenciados geograficamente.

Burroughs (1987) define um SIG como um poderoso conjunto de ferramentas para coletar, armazenar, recuperar, transformar e apresentar dados espaciais do mundo real.

Bedell (1994) define SIG de uma maneira bastante simples como qualquer sistema que trata de dados espaciais. $O$ autor detalha a definição da seguinte maneira: "uma forma particular de sistema de informação aplicada a dados geográficos; um sistema é um grupo de entes conectados e atividades que interagem para um propósito comum; um sistema de informação é um conjunto de processos executados em dados brutos, para produzir informação que será útil na tomada de decisões; um sistema de informações geográficas utiliza dados referenciados geograficamente assim como dados não espaciais e inclui operações que permitem análise espacial.".

Segundo Bonham-Carter (1994), um sistema de informação geográfica é um sistema computadorizado para manipular dados espaciais. A palavra geográfica implica que a localização dos dados é conhecida ou pode ser calculada em termos de coordenadas geográficas (latitude, longitude). A palavra informação implica que num SIG pode-se ter tanto mapas e imagens quanto dados estatísticos, tabelas e textos. A palavra sistema implica que um SIG é composto de muitos componentes, interrelacionados e ligados, com diferentes funções. Deste modo, Bonham-Carter (1994), define as seguintes atividades, como as principais relacionadas a aplicação de um SIG: organização, visualização, indagação, combinação, análise e predição.

Neste trabalho, define-se sistema de informação geográfica como um sistema para organização, padronização, indagação, análise e produção 
cartográfica de dados espaciais e seus atributos, com coordenadas conhecidas ou arbitrárias.

O geoprocessamento, segundo Rodrigues (1990), pode ser definido como o conjunto de tecnologias de coleta e tratamento de informações espaciais e de desenvolvimento, e uso de sistemas que as utilizam. As áreas que se servem das tecnologias de geoprocessamento têm em comum, 0 interesse por entes de expressão espacial, sua localização, ou distribuição, ou ainda a distribuição espacial de seus atributos.

Define-se geoprocessamento como as atividades que envolvem a utilização de sistemas para manipulação de informações espaciais com coordenadas de sistemas conhecidos ou sistemas definidos arbitrariamente.

A utilização destas tecnologias é justificada pela facilidade de entrada e recuperação de dados no sistema, que não seria possível se este não fosse digital, além disso, metodologias de análise recentes tornaram-se passiveis de aplicação somente com a popularização dos computadores pessoais de baixo custo, das técnicas de geoprocessamento e, sobretudo, dos programas e aplicativos

\subsubsection{Análise em sistemas de informação geográfica}

Um SIG é concebido como uma caixa de ferramentas de análise de mapas, mais do que um sistema de perguntas (inferência). Para a emulação de um sistema especialista como o Prospector (Stanford Research Institute, Duda, 1978), ferramentas tais como as lógica Booleana e Fuzzy podem ser incorporadas ou em, alguns casos, já fazem parte do pacote comercial de um SIG.

Segundo Katz (1991) um sistema especialista é aquele que simula um perito (especialista). Um especialista caracteriza-se por definir corretamente uma resposta, acerca de um problema, com base em informações incompletas. Os sistemas especialistas aplicam regras, fornecidas por um perito, às respostas fornecidas pelo usuário durante o processo. Estas regras são conhecidas como base de conhecimentos (knowledge base). Assim que o usuário responde às questões, o programa utiliza estas respostas para fazer outras questões relevantes até a resposta final ser definida. Um sistema especialista geralmente é 
composto de três partes: sistema de perguntas, base de conhecimentos e uma interface com o usuário. O sistema de perguntas é um programa de computador para processar as regras. A base de conhecimento utilizada, no caso de um sistema especialista, é a de um conjunto de regras compiladas por vários especialistas e armazenadas num banco de dados. A utilização deste sistema parte de uma interface que consiste de perguntas feitas ao usuário. As respostas são processadas em uma rede de inferência do sistema que foi desenvolvida a partir da experiência de peritos. A base de conhecimentos no caso de um SIG pode ser armazenada em arquivos correspondentes a planos de informação; a manipulação adequada destes planos de informação gera informações relativas à favorabilidade espacial de ocorrências minerais, além de permitir a quantificação destes dados; os procedimentos utilizados podem ser automatizados e aplicados em outros conjuntos de dados.

Atualmente os Sistemas de Informação Geográfica são bastante atraentes para se utilizar em análise de favorabilidade mineral devido à facilidade das interfaces dos sistemas, presença de diferentes métodos de análise e atualização constante dos programas além da possibilidade de se utilizar as redes de inferência desenvolvidas em sistemas especialistas aplicando-as nos SIGs com mapas. Segundo Bonham-Carter (1994), um SIG pode proporcionar várias ferramentas diferentes para auxiliar no processo de mapeamento de potencial mineral como: construção de uma base de dados, quantificação e extração de elementos dos mapas que evidenciam mineralizações, combinação de evidências com modelos matemáticos, visualização dos resultados e consulta interativa dos resultados.

Segundo Bonham-Carter (1994), a análise num SIG, além de ser conduzida visualmente também pode ser conduzida por: medidas, cálculos estatísticos, regressões e outras operações. Um exemplo de análise seria a tabulação cruzada entre ocorrências minerais e um mapa litológico, verificando quantas ocorrências estão presentes em determinadas litologias. Outra possibilidade seria a de se calcular um resumo estatístico, para se definir qual a média e desvio padrão de um levantamento aerogamaespectrométrico, no canal do urânio, de uma determinada formação geológica. O processo de análise, muitas vezes, não é feito em um único programa de computador, mas requer a 
exportação dos dados para outros programas. A análise, tanto pode ser feita a partir dos mapas, ou também, pode ser organizada a partir de tabelas, ou seja, pode-se proceder a análise tanto dos dados espaciais quanto dos atributos desses dados espaciais.

A definição de mapas de favorabilidade envolve a análise de dados espaciais visando a predição da ocorrência de mineralizações. A predição envolve utilização de ferramentas num SIG que executam a "álgebra de mapas", ou seja a possibilidade de se processar operações utilizando mapas. A predição muitas vezes pode ser utilizada para se testar a aplicação de um modelo. O modelo pode ser exclusivamente aquele que diz respeito às operações de álgebra de mapas a serem utilizadas, ou ainda, pode-se tratar do modelo que definiu os mapas a serem utilizados e a importância relativa e absoluta de cada mapa.

Segundo Bonham-Carter (1994), na aplicação de um SIG no mapeamento de potencial mineral, o modelo de depósito é importante tanto na seleção quanto na derivação (separação de classes de interesse) de mapas que representariam os melhores metalotectos do modelo em questão, além disso, os modelos podem auxiliar na definição dos pesos de cada mapa segundo sua importância.

Para análise de favorabilidade mineral podem-se utilizar dois métodos de quantificação: o conduzido pelo conhecimento (knowledge-driven) e o conduzido pelos dados (data-driven) (Bonham-Carter, 1994). O método conduzido pelos dados caracteriza-se pela utilização de ocorrências minerais para, por indução, definir zonas favoráveis à mineralização relacionadas às diversas caracteristicas da área, como anomalias geoquímicas, anomalias geofísicas e feições litológicas e geológicas. O método conduzido pelo conhecimento utiliza um modelo de mineralização para a área de estudo e por dedução, a partir dos diversos dados, define zonas de favorabilidade à ocorrência das mineralizações associadas ao modelo utilizado.

Entre as limitações das duas aproximações apresentadas destacam-se as seguintes: no caso do método conduzido pelos dados, as limitações referem-se à quantidade de ocorrências minerais conhecidas na área e sua distribuição espacial, que pode refletir a heterogeneidade do conhecimento na área de estudo, gerando desvios nos resultados das análises; no caso do método conduzido pelo conhecimento, há dificuldades com os dados espaciais que não têm expressão 
mapeável regionalmente, como por exemplo, associações mineralógicas específicas ou padrões de alteração de rocha, os quais dificilmente estão disponiveis em mapeamentos sistemáticos como ocorre com os mapas geológicos.

O método conduzido pelo conhecimento pode ser aplicado através de diferentes modelos de análise; entre eles destacam-se o modelo lógico booleano e o modelo de índices somativos (ou indices ponderados).

\subsubsection{Método lógico booleano}

No método booleano cada mapa pode ser considerado como um nivel de evidência. As evidências apresentadas em cada mapa (níveis) são reduzidas a dois valores, (1) quando a proposição é satisfeita (verdadeira) ou (0) quando a proposição não é satisfeita (falsa). Vários niveis podem ser combinados para elaborar uma hipótese ou proposição. A combinação dos diversos mapas (níveis) pode ser feita a partir dos operadores lógicos booleanos, entre eles, destacam-se os seguintes: intersecção (AND), união (OR), exclusão (NOT), exclusão comum a todos os conjuntos (XOR).

O operador AND considera apenas a intersecção dos conjuntos como verdadeira. $O$ operador $O R$ considera a união de todos os conjuntos como verdadeira. O operador NOT corresponde a uma operação de exclusão. $O$ operador XOR apresenta um resultado verdadeiro somente se A e B tiverem valores diferentes, de outra maneira o resultado é falso.

A figura 7 mostra graficamente os operadores, utilizando o diagrama de Venn.

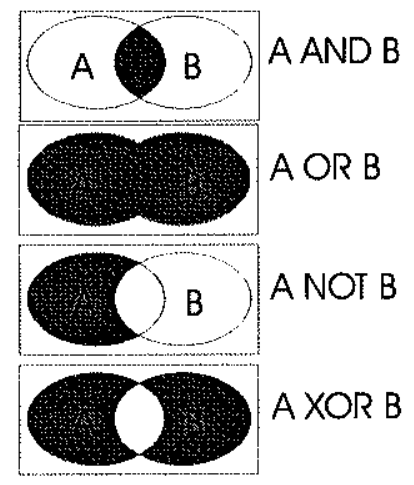

Figura 7: Operadores lógicos booleanos 
As operações AND e OR podem ser definidas da seguinte maneira:

- AND: intersecção de $A$ e $B, A \cap B=\{x \mid x \in A$ e $x \in B\}$

- OR: união de $A$ e $B, A \cup B=\{x \mid x \in A$ ou $x \in B\}$

\subsubsection{Método de índices}

O aspecto positivo do método booleano é a simplicidade. Contudo este método não dá a importância devida a cada critério que está sendo combinado. $A$ execução de uma análise mais detalhada requer a ponderação das evidências baseada na sua significância.

O tipo mais simples de índices ponderados (Bonham-Carter, 1994) é aquele cujos mapas de entrada são binários e cada mapa tem um único fator de ponderação. Entretanto, quando utilizam-se mapas multi-classes, a cada classe, em todos os mapas, é dada uma pontuação diferente, permitindo um sistema de ponderação mais flexível.

Segundo a metodologia baseada em Bonham-Carter (1994), no caso dos mapas binários, cada mapa é simplesmente multiplicado pelo seu fator de ponderação, somado com todos os mapas que estão sendo combinados e normalizado pela soma dos pesos. O resultado é um valor que varia entre 0 e 1 , que pode ser classificado em intervalos apropriados para mapeamento. Em qualquer localização, a pontuação de saída $S$ é definida como:

$$
S=\frac{\left.\sum_{i}^{n} W_{i . c l a s s e(M a p a i}\right)}{\sum_{i}^{n} W_{i}}
$$

onde: $W_{i}=$ peso do i-ésimo mapa

Classe $($ Mapa $\mathrm{i})=$ é 1 para a presença ou 0 para a ausência da condição binária.

No caso dos mapas multiclasse, para as classes que ocorrem em cada mapa de entrada, são definidas diferentes pontuações, assim como os mapas recebem diferentes pesos (Bonham-Carter, 1994). 
É conveniente definir pontuações numa tabela de atributos para cada mapa de entrada.

A média da pontuação é então definida como:

$$
S=\frac{\sum_{i}^{n} S_{i j .} W_{i}}{\sum_{i}^{n} W_{i}}
$$

onde: S é a pontuação ponderada para um objeto (polígono, pixel)

Wi é o peso para o i-ésimo mapa de entrada

Sij é a pontuação para a classe enésima do i-ésimo mapa; o valor de j depende da classe de cada diferente ocorrência.

A técnica, também chamada de índices somativos, é caracterizada pela definição prévia da importância relativa de cada dado espacial (e seus respectivos atributos). Esta importância relativa pode ser resumida na expressão de pesos diferentes para cada mapa temático. A combinação dos mapas de diferentes pesos objetiva gerar uma saída em que se definem várias classes, os maiores valores indicarão maior número de condições satisfeitas e os menores valores as áreas de menor probabilidade de se satisfazer as condições do modelo utilizado.

\subsubsection{Método lógico fuzzy}

Segundo Bonham-Carter (1994), enquanto na teoria clássica a pertinência de um conjunto é definida como verdadeira ou falsa, 1 ou 0 , a pertinência fuzzy é expressa numa escala contínua que varia de 1 (inteiramente pertinente/associado) a 0 (inteiramente não pertinente/associado). Desta maneira, Bonham-Carter (1994) exemplifica a utilização do método lógico Fuzzy a partir do teor de arsênio (As) nos sedimentos de um lago. Este teor pode ser definido de acordo com o grau de pertinência num conjunto chamado "Anomalia de arsênio". Valores muito altos de arsênio seriam então definitivamente anômalos com um valor de pertinência fuzzy igual a 1, valores muito baixos teriam uma pertinência fuzzy de valor igual a zero. Entre esses extremos há uma escala de valores possiveis. Tal função poderia ser analiticamente descrita como: 


$$
\mu(x)=\left\{\begin{array} { l } 
{ 0 } \\
{ \frac { x - 5 0 } { 2 0 0 } } \\
{ 1 }
\end{array} \rightarrow \left\{\begin{array}{l}
x<50 \\
50<x<250 \\
x>250
\end{array}\right.\right.
$$

onde $x$ é concentração de Arsênio, e $\mu(x)$ é função de pertinência fuzzy. Todo valor de $x$ associado com o valor de $\mu(x)$, e ordenados em pares $[x, \mu(x)]$ são conhecidos como um conjunto de pertinência fuzzy. O formato da função não precisa ser necessariamente linear, podendo ser desenvolvida analiticamente ou arbitrariamente de acordo com o problema estudado. A figura 8 mostra exemplos de funções de pertinência.
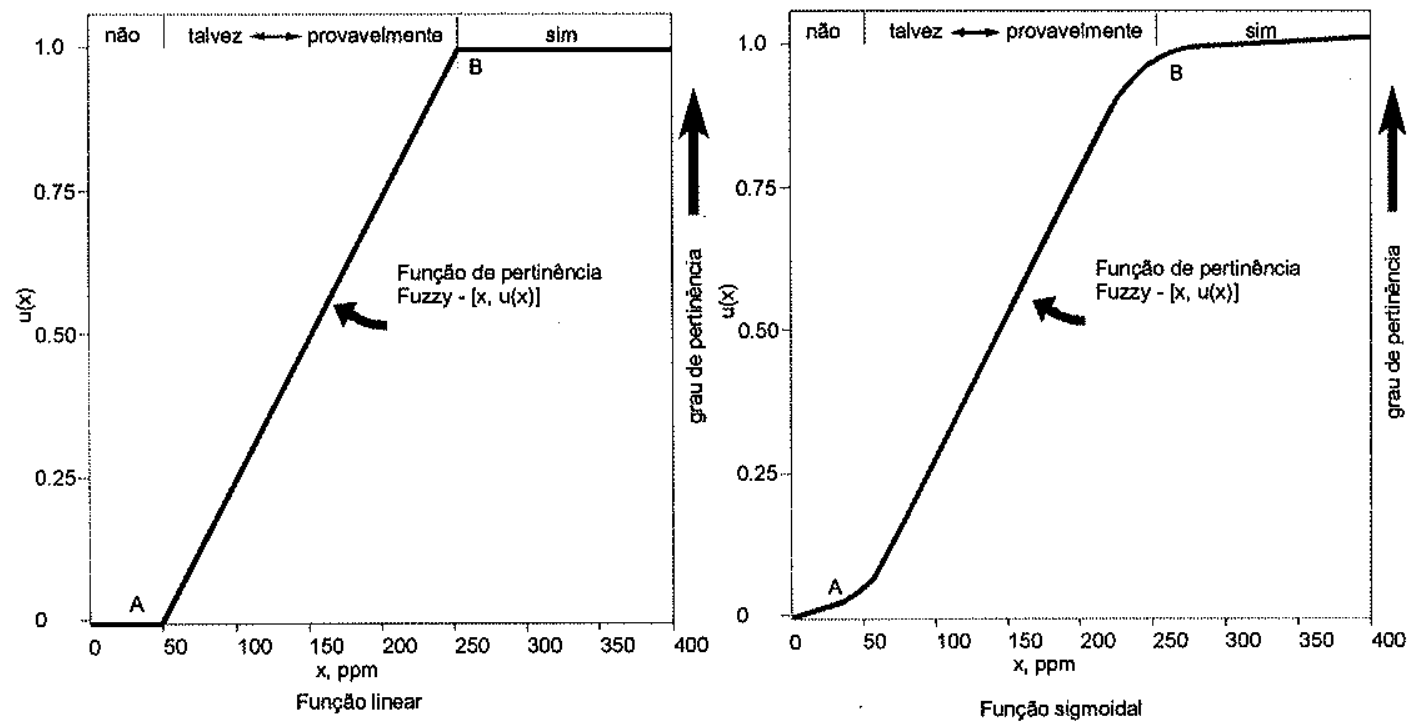

Modificado de Bonham-Carter (1994)

Figura 8: Funções de pertinência fuzzy.

Dados dois ou mais mapas com uma função de pertinência fuzzy para um mesmo conjunto, podem-se empregar vários operadores diferentes.

Dentre os operadores possiveis os chamados operadores fuzzy AND e fuzzy OR caracterizam-se por serem equivalentes às operações AND e OR booleanas.

O operador fuzzy AND caracteriza-se por ser conservador, admitindo os menores valores numa combinação; já o operador fuzzy OR caracteriza-se por admitir os maiores valores para qualquer conjunto de entrada.

A operação algébrica fuzzy de soma caracteriza-se por "reforçar" uma evidência, contudo a soma das evidências é automaticamente limitada pelo valor máximo de 1 , o qual nunca pode ser excedido. 
A operação algébrica fuzzy de produto carcteriza-se por ser decrescente, ou seja a multiplicação da pertinência fuzzy sempre vai gerar um valor menor que o menor dos membros.

Uma operação intermediária entre a operação fuzzy de soma e a de produto é a chamada operação Gama, expressa pela seguinte função:

$$
\mu_{\text {comb }}=(\text { SomaFuzzy })^{\gamma} *(\text { Fuzzyproduto })^{1-\gamma}
$$

onde $\gamma$ é o parâmetro escolhido num intervalo de $(0,1)$, quando $\gamma=1$ a combinação é a mesma da operação de soma, e quando $\gamma=0$ o efeito é o mesmo da operação de produto.

$\mathrm{Na}$ prática é interessante utilizar diferentes operadores em um mesmo problema. Planos de informação podem ser combinados juntos numa série de passos, como numa rede de inferência. Deste modo a combinação de todos os mapas pode ser feita utilizando-se primeiramente um tipo de operador para as hipóteses intermediárias (mais conservadoras ou mais arriscadas). Deste modo a rede de inferência torna-se um meio importante de simular o pensamento lógico de um perito. Na terminologia dos sistemas especialistas a função de pertinência fuzzy seria a base de conhecimento, já a rede de inferências e as regras de combinação fuzzy seriam o sistema de inferência. A lógica fuzzy é uma das ferramentas empregadas quando a incerteza da evidência é importante.

\subsubsection{Avaliação de favorabilidade a partir de critérios múltiplos por geoprocessamento}

Critérios formam a base de uma decisão a partir de elementos que podem ser medidos ou avaliados. Esta inferência é baseada nos objetivos da avaliação. $\mathrm{Na}$ avaliação de favorabilidade, os parâmetros prospectivos são os critérios, e as áreas de maior favorabilidade de ocorrência mineral são os objetivos da avaliação. Segundo Eastman et al.(1995) e Eastman (1997), os critérios podem ser de dois tipos: os fatores e as restrições.

O fator, de um modo geral, é um critério que aumenta ou diminui o peso de uma determinada alternativa para a atividade em consideração. A restrição limita as alternativas em consideração (Eastman, 1997). 
No caso da avaliação de favorabilidade, os fatores são constituidos pelos elementos principais relacionados aos parâmetros prospectivos, ou seja, os fatores são constituídos de elementos litológicos, estratigráficos, geoquímicos e estruturais.

Deste modo, as regras de decisão são constituídas pelos critérios, sejam fatores e restrições, assim como pelos procedimentos de combinação dos critérios. As regras de decisão, desta maneira, dependem intrinsecamente do objetivo específico da análise. Para a avaliação de favorabilidade mineral o objetivo específico é descrito como a definição da ocorrência de mineralizações e sua localização. Os critérios são definidos a partir dos parâmetros de prospecção, que são baseados nos aspectos genéticos e descritivos das mineralizações conhecidas.

Para a avaliação a partir de vários critérios pode-se utilizar, segundo Eastman (1997) a sobreposição booleana, a combinação linear ponderada (CLP) e a média ponderada ordenada (MPO). A combinação linear ponderada e a média ponderada ordenada são variações da técnica de sobreposição de camadas ou índices somativos (index overlay). $\mathrm{Na}$ verdade estas técnicas aplicam índices ponderados aos niveis de informação antes de proceder a sobreposição, que em geral é feita a partir de uma operação algébrica de soma. $O$ método e as definições apresentadas a seguir são baseados em Eastman (1997).

A sobreposição booleana reduz os fatores a elementos binários e os combina a partir de operadores booleanos como o AND e o OR. No caso do operador AND (intersecção) obtem-se o mínimo de áreas favoráveis possiveis (resultado pessimista), ou seja, obtém-se apenas as áreas onde há sobreposição de informações em todos os niveis de informação utilizados. No caso do operador OR (união), obtem-se o máximo de áreas favoráveis possíveis (resultado otimista), ou seja, o mapa final conta com todas as informações de todos os níveis de informação utilizados.

A combinação linear ponderada é aplicada segundo a seguinte equação:

$$
F=\sum p_{i j} \cdot x_{i}
$$

onde:

$\mathrm{F}=$ favorabilidade

$p_{i j}=$ peso da classe $j$ do mapa $\mathbf{i}$ 


$$
x_{i}=\text { peso do mapa } i
$$

A tabela 9 apresenta um caso numérico (baseado em trabalho de Eastman, 1997) no qual foi aplicada uma análise por combinação linear ponderada. Os termos utilizados na tabela foram adaptados para o caso da análise de favorabilidade desenvolvida neste trabalho.

Tabela 9: Exemplo de combinação linear ponderada

\begin{tabular}{|c|c|c|c|c|c|}
\hline Fator & Peso da classe & $\begin{array}{l}\text { Peso do fator segundo uma } \\
\text { análise aos pares }\end{array}$ & Avaliaçăo & $\begin{array}{l}\text { Soma dos } \\
\text { pesos }\end{array}$ & $\begin{array}{l}\text { Soma } \\
\text { ponderada }\end{array}$ \\
\hline$A$ & 187 & 0,3 & 56,1 & & \\
\hline B & 174 & 0,5 & 87 & 1,0 & 183,3 \\
\hline C & 201 & 0,2 & 40,2 & & \\
\hline
\end{tabular}

(modificado de Eastman,1997)

O processo de combinação linear ponderada padroniza os fatores a uma escala numérica comum. Obtém-se um mapa contínuo de favorabilidade que pode ser reclassificado para intervalos adequados à tomada de decisões, ou ainda, pode-se definir um limiar para separar as áreas de interesse. Este procedimento é caracterizado por gerar um resultado situado entre a sobreposição booleana, utilizando o operador AND, e a sobreposição booleana, utilizando o operador $\mathrm{OR}$, ou seja, é possível definir um mapa de favorabilidade num conjunto intermediário entre a operação de união (hipótese otimista) e a de intersecção (hipótese pessimista). Além disso, este procedimento diferencia-se da sobreposição booleana pois considera os pesos de cada fator. No caso booleano os fatores são rígidos, verdadeiros ou falsos, na análise linear ponderada pode-se utilizar uma escala contínua de favorabilidade para cada fator. Este conceito relativo, da escala contínua, foi apresentado na discussão sobre método fuzzy. Assim pode-se utilizar o conceito fuzzy para definir as áreas favoráveis em cada fator e também para definir o limite entre o que é favorável e o não favorável.

$\mathrm{Na}$ análise por combinação linear ponderada, as classes de cada fator têm pesos diferentes e sofrem uma ponderação relativa. Entretanto os fatores analisados tem valores mínimos e máximos iguais entre si, não se atribui um peso maior a um fator em detrimento de outro fator. Desse modo, na análise por combinação linear não é possível controlar a ordem de importância de cada fator. Controla-se apenas a importância de cada fator segundo a ponderação de suas 
classes, independente de sua ordenação relativa aos outros fatores. Desta forma, na comparação entre a análise por combinação linear ponderada e a análise booleana para um mesmo conjunto de dados, verifica-se que a combinação linear ponderada resultaria exatamente no centro, entre a hipótese otimista e a hipótese pessimista. $\mathrm{Na}$ verdade não se verifica, de fato, uma escala contínua de favorabilidade entre as operações de união e de intersecção. Esta questão é discutida a partir da metodologia de análise por média ponderada ordenada apresentada a seguir.

A média ponderada ordenada é um procedimento de análise semelhante à combinação linear ponderada. Contudo, nesse método considera-se também o chamado peso de ordenação. O peso de ordenação serve para modificar os pesos de cada mapa antes destes serem aplicados.

$$
F=\sum p_{i j} \cdot x_{i} \cdot p o_{i}
$$

onde:

$F=$ favorabilidade

$\mathrm{p}_{\mathrm{ij}}=$ peso da classe $\mathrm{j}$ do mapa $\mathrm{i}$

$x_{i}=$ peso do mapa $i$

$\mathrm{po}_{\mathrm{i}}=$ peso de ordenação do mapa $\mathrm{i}$

As tabelas 10 e 11 mostram casos de aplicação da média ponderada ordenada.

Se for feita uma atribuição de pesos de ordenação, de modo que se utilize apenas o fator de maior peso, obtêm-se os resultados apresentados na tabela 10.

Tabela 10: Exemplo de média ponderada ordenada

\begin{tabular}{|c|c|c|c|c|c|c|c|}
\hline Fator & $\begin{array}{l}\text { Peso da } \\
\text { classe }\end{array}$ & $\begin{array}{l}\text { Peso do fator } \\
\text { (análise aos pares) }\end{array}$ & $\begin{array}{l}\text { Peso de } \\
\text { ordenação }\end{array}$ & $\begin{array}{l}\text { Peso } \\
\text { modificado }\end{array}$ & Avaliação & $\begin{array}{l}\text { Soma } \\
\text { dos } \\
\text { pesos }\end{array}$ & $\begin{array}{l}\text { Soma } \\
\text { ponderada }\end{array}$ \\
\hline$B$ & 174 & 0,5 & 1 & 0,5 & 87 & & \\
\hline A & 187 & 0,3 & 0 & 0 & 0 & 0,5 & 174 \\
\hline C & 201 & 0,2 & 0 & 0 & 0 & & \\
\hline
\end{tabular}

(modificado de Eastman,1997)

Pode-se fazer a inversão dos pesos de ordenação, atribuindo o maior peso de ordenação ao fator de menor peso. Obtêm-se o resultado apresentado na tabela 11. 
Tabela 11: Exemplo de média ponderada ordenada - inversão dos pesos de ordenação

\begin{tabular}{|c|c|c|c|c|c|c|c|}
\hline Fator & $\begin{array}{l}\text { Peso da } \\
\text { classe }\end{array}$ & $\begin{array}{l}\text { Peso do fator } \\
\text { (análise aos pares) }\end{array}$ & $\begin{array}{l}\text { Peso de } \\
\text { ordenação }\end{array}$ & $\begin{array}{l}\text { Peso } \\
\text { modificado }\end{array}$ & Avaliação & $\begin{array}{l}\text { Soma } \\
\text { dos } \\
\text { pesos }\end{array}$ & $\begin{array}{l}\text { Soma } \\
\text { ponderada }\end{array}$ \\
\hline $\mathrm{B}$ & 174 & 0,5 & 0 & 0 & 0 & & \\
\hline A & 187 & 0,3 & 0 & 0 & 0 & 0,2 & 201 \\
\hline C & 201 & 0,2 & 1 & 0,2 & 40,2 & & \\
\hline
\end{tabular}

(modificado de Eastman,1997)

Verifica-se que ao atribuir o peso de ordenação 1 ao fator de maior peso, na tabela 10, obteve-se um resultado mínimo correspondente ao operador AND dos conjuntos fuzzy.

Por outro lado, ao atribuir o peso de ordenação 1 ao fator de menor peso na tabela 11, obteve-se um resultado máximo, correspondente ao operador $O R$ dos conjuntos fuzzy.

No caso dos pesos de ordenação serem iguais, o resultado seria o mesmo de uma análise por combinação linear ponderada, como pode ser verificado na tabela 12 em comparação com a tabela 9.

Tabela 12: Exemplo de média ponderada ordenada - pesos de ordenação iguais

\begin{tabular}{|c|c|c|c|c|c|c|c|}
\hline Fator & $\begin{array}{l}\text { Peso da } \\
\text { classe }\end{array}$ & $\begin{array}{l}\text { Peso do fator } \\
\text { (análise aos pares) }\end{array}$ & $\begin{array}{l}\text { Peso de } \\
\text { ordenação }\end{array}$ & $\begin{array}{l}\text { Peso } \\
\text { modificado }\end{array}$ & Avaliação & $\begin{array}{l}\text { Soma } \\
\text { dos } \\
\text { pesos }\end{array}$ & $\begin{array}{l}\text { Soma } \\
\text { ponderada }\end{array}$ \\
\hline $\bar{B}$ & 174 & 0,5 & 0,33 & 0,17 & 29,58 & & \\
\hline A & 187 & 0,3 & 0,33 & 0,1 & 18,7 & 0,34 & 183,3 \\
\hline C & 201 & 0,2 & 0,33 & 0,07 & 14,07 & & \\
\hline
\end{tabular}

(modificado de Eastman,1997)

A média ponderada ordenada permite ponderar os fatores relativamente, ordenando-os, de maneira a influenciar o resultado segundo a importância relativa de cada fator (importância em relação ao grupo de fatores), além de considerar o peso absoluto de cada fator, como é feito no caso da combinação linear ponderada. Conclui-se que a combinação linear ponderada é um caso da média ponderada ordenada, este caso é caracterizado por uma ordenação da importância dos fatores onde um único peso é atribuído a todos os fatores. 


\subsection{Dados levantados e coleta das informações}

\subsubsection{Digitalização da topografia e da rede de drenagem}

Foram digitalizados, em mesa digitalizadora, as seguintes cartas topográficas na escala 1:50.000:

Tabela 13: Cartas topográficas digitalizadas

\begin{tabular}{lll}
\hline $\begin{array}{l}\text { Folha topográfica (cartas na escala } \\
\text { 1:50.000) }\end{array}$ & Instituição & $\begin{array}{l}\text { Intervalo de restituiçăo das curvas de } \\
\text { nivel }(\mathrm{m})\end{array}$ \\
\hline Apial & IBGE* & 20 \\
Iporanga & IBGE & 20 \\
Marquês de Abrantes (ou Epitácio & IBGE & 20 \\
Pessoa) & & \\
Barra do Turvo & IBGE & 20 \\
Vila Branca & DSG** & 40 \\
Ribeira & DSG & 40 \\
Cerro Azul & DSG & 40 \\
Tunas & DSG & 40 \\
\hline
\end{tabular}

"Instituto Brasileiro de Geografia e Estatística - Superintendência de Cartografia

** Ministério do Exército - Diretoria do Serviço Geográfico

Além das cartas topográficas, também foram digitalizados alguns dos mapas geológicos utilizados na compilação do mapa geológico da área.

Os dados foram digitalizados segundo um sistema cartográfico de referência: UTM - Universal Transversal Mercator. Toda a base de dados foi referenciada segundo este sistema.

Keefer et al. (1991) fizeram uma série de testes de digitalização de mapas, em mesa digitalizadora, visando correlacionar os erros apurados a uma distribuição normal destes erros, definindo desta forma os valores de desvio em função das distâncias de captura utilizadas na digitalização.

Alguns dos valores estão presentes na tabela 14. Os valores em polegadas foram convertidos para milimetros e apresenta-se uma coluna com o valor em metros, segundo uma extrapolação feita por Guimarães Filho (1994). 
Tabela 14: Erros de digitalização com captura contínua de pontos

\begin{tabular}{llll}
\hline Distância $(\mathrm{pol})$ & Distância $(\mathrm{mm})$ & $\begin{array}{l}\text { Valor em metros } \\
\text { (escala } 1: 50.000)\end{array}$ & $\begin{array}{l}\text { Desvio Padrăo do perímetro em \% } \\
\alpha=0,025(95 \%)\end{array}$ \\
\hline 0,020 & 0,508 & 25,40 & 0,588 \\
0,040 & 1,016 & 50,80 & 1,869
\end{tabular}

(Modificado de Guimarães Filho, 1994)

Definiu-se, com base nos dados apresentados por Keefer et al. (1991), o valor de 15 metros como máximo aceitável para um erro médio quadrático na calibragem dos mapas em mesa digitalizadora, o que significa na escala 1:50.000 erros da ordem de $0,3 \mathrm{~mm}$ no papel. A digitalização foi feita a cada intervalo de cota de curva de nível de $40 \mathrm{~m}$ utilizando-se mesa digitalizadora, o intervalo de captura automático de pontos foi definido para um valor de 30 metros.

Optou-se por utilizar o valor de 30 metros, o qual proporciona boa fidelidade aos dados originais e permite economia em termos de informação digital armazenada.

Além das curvas de nivel, foram digitalizadas as drenagens em todas as cartas.

\subsubsection{Dados geoquímicos}

Utilizaram-se os dados geoquímicos de sedimentos de corrente do projeto Geoquímica no Vale do Ribeira (Morgental et al., 1978) cedidos pela Companhia de Pesquisa de Recursos Minerais (CPRM). Este projeto engloba os dados do projeto Sudelpa (Morgental et al., 1975). Foram utilizados, destes dados, os resultados das análises por espectrografia de absorção atômica, relativos às amostras (abertura com ácido nítrico concentrado à quente, fração $80 \mathrm{mesh}$ ) da Subárea Sudelpa, Geoquímica Regional e Follow up. Não se utilizaram os dados do estudo orientativo.

Levantaram-se os dados de projetos geoquímicos semi-regionais e de detalhe realizados pela Mineropar na área. Licht \& Tarvainen (1996) descrevem o banco de dados geoquímicos do estado do Paraná. As amostras de sedimentos de corrente foram abertas por água régia, com excessão do projeto Vale do Ribeira, cujas amostras foram abertas por reação com ácido nítrico 
concentrado a quente. As amostras de todos os projetos foram analisadas por absorção atômica (fração 80 mesh). A área de estudo (folhas Cerro Azul e Apiaí, 1:100.000) é abrangida pelos projetos apresentados na tabela 15.

Tabela 15: Relação de levantamentos geoquímicos da Mineropar no Vale do Ribeira

\begin{tabular}{ll}
\hline Projeto & Elementos analisados \\
\hline Paraíso & $\mathrm{Cu} \mathrm{Pb}$ \\
Marquês de Abrantes & $\mathrm{Pb}$ \\
Nagib Silva & $\mathrm{Cu} \mathrm{Pb} \mathrm{Zn}$ \\
Barra do Itapirapuã & $\mathrm{Cu} \mathrm{Pb} \mathrm{Zn}$ \\
Săo Silvestre & $\mathrm{Cu} \mathrm{Pb} \mathrm{Zn}$ \\
Volta Grande & $\mathrm{Cu} \mathrm{Pb} \mathrm{Zn}$ \\
Canha-Carumbé & $\mathrm{Pb}$ \\
Granitos & $\mathrm{Cu} \mathrm{Pb} \mathrm{Zn}$ \\
Capivari Pardo & $\mathrm{Cu} \mathrm{Pb} \mathrm{Zn}$ \\
Vale do Ribeira & $\mathrm{Cu} \mathrm{Pb} \mathrm{Zn}$ \\
\hline
\end{tabular}

\subsubsection{Dados geofísicos}

Foram utilizados dados dos levantamentos aerogeofísicos Serra do Mar Sul (CPRM-Geofoto, 1978) e São Paulo - Rio de Janeiro (CPRM-Encal, 1979).

O projeto Serra do Mar Sul foi contratado pelo DNPM/CPRM e executado pela empresa Geofoto em 1978, com as características técnicas apresentadas na tabelas 16.

Tabela 16: Características técnicas do projeto Serra do Mar Sul

Levantamento de dados magnéticos utilizando magnetômetro de precessão nuclear, modelo G803, fabricado pela Geometrics.

Levantamento gamaespectrométrico utilizando gamaespectrômetro Exploranium DIGRS-3001 com volume de cristal de $1017.87 \mathrm{pol}^{3}$.

Direçăo das linhas de vóo: N30W

Espaçamento entre linhas de vôo: $1,0 \mathrm{~km}$

Direçăo das linhas de controle: N60E

Espaçamento entre as linhas de controle: $20 \mathrm{~km}$

Altura média de vôo: 150m

Navegaçăo: controle visual

Recuperação dos vôos: recuperação com base no filme de rastreio

Aeronave: Islander 
O projeto São Paulo - Rio de Janeiro foi contratado pelo DNPM/CPRM e executado pela empresa Encal em 1979, com as características técnicas apresentadas na tabela 17 .

Tabela 17: Características técnicas do projeto São Paulo - Rio de Janeiro

Levantamento de dados magnéticos utilizando magnetómetro tipo próton, modelo G-803, fabricado pela Geometrics, montado em ponta de cauda.

Levantamento gamaespectrométrico utilizando gamaespectro̊metro Geometrics GR-800A com volume de cristal de $3072 \mathrm{pol}^{3}$.

Direção das linhas de vôo: NS

Espaçamento entre as linhas de vôo: $1.0 \mathrm{~km}$

Direção das linhas de controle: EW

Espaçamento entre as linhas de controle: $10 \mathrm{~km}$

Altura média de vo̊o: $150 \mathrm{~m}$

Navegação: sistema doppler e controle visual

Recuperação dos vôos: "visual data display" e recuperação das linhas com base no filme de rastreio

Aeronave: Bandeirante

Os dados gamaespectrométricos foram pré-processados pelo projeto Brazil Airborne Radiometric Mapping Project (CPRM-BARMP (1997)), contratado pela Companhia de Pesquisa de Recursos Minerais (CPRM) e executado por Paterson, Grant \& Watson Limited. Este projeto tratou da conversão dos dados de cps para ppm, nos canais do $\mathrm{K}, \mathrm{U}$ e Th, além da retirada de ruídos e micronivelamento.

A remoção de "spikes" foi feita pelo projeto CPRM-BARMP (1997), utilizando um filtro de remoção de ruídos. Segundo o relatório técnico do projeto CPRM-BARMP (1997), os perfis de dados foram filtrados utilizando-se um filtro passa-baixa não linear Naudy, com uma distância de amostragem de 1/2 comprimento de onda. Em seguida à remoção dos "spikes, os dados foram filtrados utilizando um filtro de suavização $5 \times 5$, com os seguintes coeficientes: $0.1107,0.2215,0.3356,0.2215,0.1107$.

O micronivelamento consiste na retirada de ruidos provenientes do tipo de amostragem que é feita nos aerolevantamentos. Essa amostragem é caracterizada por ter uma densidade maior na direção das linhas de vôo do que 
entre linhas de vôo. Ao serem interpolados em grades, os dados apresentam ruídos paralelos à linha de vôo, ou seja, um comprimento de onda longo paralelo às linhas de vôo e um comprimento de onda curto perpendicular às linhas de vôo.

Segundo o relatório técnico do projeto CPRM-BARMP (1997), os dados, após a remoção dos "spikes", foram interpolados em grade utilizando-se o algoritmo de ajuste à mínima curvatura (GIPSI Rangrid, pacote de programas PGW ) com uma célula igual a $1 / 4$ da distância entre linhas de vôo. O primeiro passo no micronivelamento consistiu na aplicação de dois filtros de Fourier na grade: um cosseno ao quadrado direcional e um filtro passa alta de Butterworth. $O$ efeito destes filtros é deixar passar apenas aqueles elementos que são estreitos (comprimento de onda curto) na direção perpendicular às linhas de vôo. São extraídos valores a partir dessa grade filtrada, para compor um novo canal que contém o ruído da linha de vôo mais algum sinal geológico. Este canal é então filtrado com um filtro de passa baixa Naudy, de comprimento de onda longo, para separar o ruído da linha de vôo do comprimento de onda mais curto dos elementos geológicos. O limiar do comprimento de onda do filtro de grade passa alta é definido para ser muitas vezes maior, do que o limiar do comprimento de onda do filtro passa alta, que foi previamente aplicado, de modo que o canal de ruído contém somente elementos de "stripe", que são consideravelmente mais longos na direção da linha de vôo, do que na direção perpendicular. Subtraindo este canal de ruído, filtrado dos dados originais, elimina-se o ruído das linhas de vôo, obtendo-se os dados micronivelados.

A partir dos dados micronivelados, foram aplicados padrões de conversão dos dados gamaespectrométricos de cps para ppm. A conversão foi feita a partir de parâmetros de conversão levantados em campo. Segundo o relatório técnico do projeto CPRM-BARMP (1997) também foi corrigido o nivelamento entre levantamentos adjacentes de modo a formar um grid contínuo. Este é um fator que permite juntar os dados dos projetos Serra do Mar Sul e São Paulo - Rio de Janeiro em uma única grade. 


\subsubsection{Dados de ocorrências minerais}

O banco de dados de ocorrências minerais é baseado no arquivos digitais do banco de dados CPRM-Microsiga (1994) (Sistema de Informações Geológicas do Brasil) e nos arquivos digitais do banco de dados IDEM (Figueiredo, 1988) (Índice de DEpósitos Minerais). Além disso, foram utilizados dados obtidos a partir da digitalização de ocorrências encontradas nos mapas do projeto Anta Gorda (MMAJ-JICA,1981, 1982, 1983). Todos os dados foram organizados na forma de uma planilha eletrônica. $O$ banco de dados contava com 479 pontos, antes de ser minuciosamente analisado (ver capítulo sobre tratamento e análise dos dados), 0 banco de dados final conta com 113 ocorrências.

\subsubsection{Compilação do mapa geológico}

Para a compilação do mapa geológico, foram utilizados os dados citados na tabela 18.

Tabela 18: Dados utilizados na compilação do mapa geológico

Levantamentos geologicos na escala 125.000

- MMAJ-JICA, $(1982,1983)$ Anta Gorda Project

Eevantamentos geologios os na escana 10000

- Campanha, 1991, Tectónica Proterozóica no alto e médio Vale do Ribeira, estados de São

Paulo e Paraná.

- Mello, 1995, Geologia e Estudo Metalogenético do maciço Itaoca, Vale do Ribeira (SP e PR).

Levantamentos geologicos na escala 1100000

- Silva et al., 1981, Projeto Integração e detalhe geológico no Vale do Ribeira. DNPM/CPRM.

Levantamentos geologicos na escala 1250000

- Biondi, 1983, Mapa Geológico da Área de Embasamento do Estado do Paraná.

- Campanha et al., 1995 Mapa Geológico da Folha Itararé.

A estratigrafia utilizada na compilação foi baseada no mapa Geológico da Folha Itararé (Campanha et al., 1995). A partir dessa base foram feitas alterações na estratigrafia considerando-se observações feitas por Campanha (informação verbal). 


\subsection{Tratamento e método de análise dos dados}

\subsubsection{Geração de modelo numérico de terreno}

A partir das curvas de nivel digitalizadas com intervalos de cota de 40 metros foi feito um modelo numérico de terreno (MNT). O modelo numérico de terreno foi calculado a partir da interpolação por rede triangular irregular (TIN triangular irregular network) utilizando-se o sistema Arclnfo 7.0

O modelo (Figura 12) TIN representa uma superfície como um conjunto de faces de triângulos contínuos os quais não se sobrepõem aos vértices. Cada triângulo corresponde a uma superfície. O interpolador utilizado na construção do TIN segue o método da triangulação de Delaunay.

Segundo Pettinati (1983) a triangulação de Delaunay é definida da seguinte maneira: "Para cada ponto de controle Pi amostrado inicialmente, é possível determinar à sua volta uma região que seja o lugar geométrico dos pontos do plano mais próximos de Pi do que de qualquer outro ponto de controle. $O$ conjunto destas regiões forma um agrupamento de polígonos convexos cobrindo todo o plano; esta construção recebe o nome de Divisão de Dirichlet.". Segundo a Divisão de Dirichlet, um polígono convexo é definido em torno de cada ponto amostrado, de modo que dois polígonos contíguos possuam apenas uma aresta em comum, a qual é equidistante dos pontos internos aos referidos polígonos.

A figura 11 é um esquema da topologia do modelo numérico TIN e mostra uma série de pontos, com atributos $x, y, z$ ligados aos seus vizinhos a partir de uma série de triângulos cujas faces correspondem a uma superfície. Para cada triângullo a estrutura do TIN guarda um número de ordem, uma lista de três nós definindo o triângulo, as coordenadas $x$, y de cada nó, o valor $z$ de cada nó e uma lista dos três triângulos adjacentes.

O modelo numérico de terreno é apresentado na figura 10. Esta figura foi gerada a partir da fusão de dois níveis de informação. Um deles corresponde a um sombreamento artificial do MNT a partir de uma fonte N45W com inclinação de $45^{\circ}$ e o outro nível corresponde a uma classificação para 255 classes de cores, também do MNT, que variam do azul ao vermelho, e representam as variações de cotas de 60 a 1200 metros presentes na área. 
A fusão destes dois niveis de informação foi feita utilizando-se a técnica de transformação IHS (Intensity/Intensidade, Hue/Matiz, Saturation/Saturação).

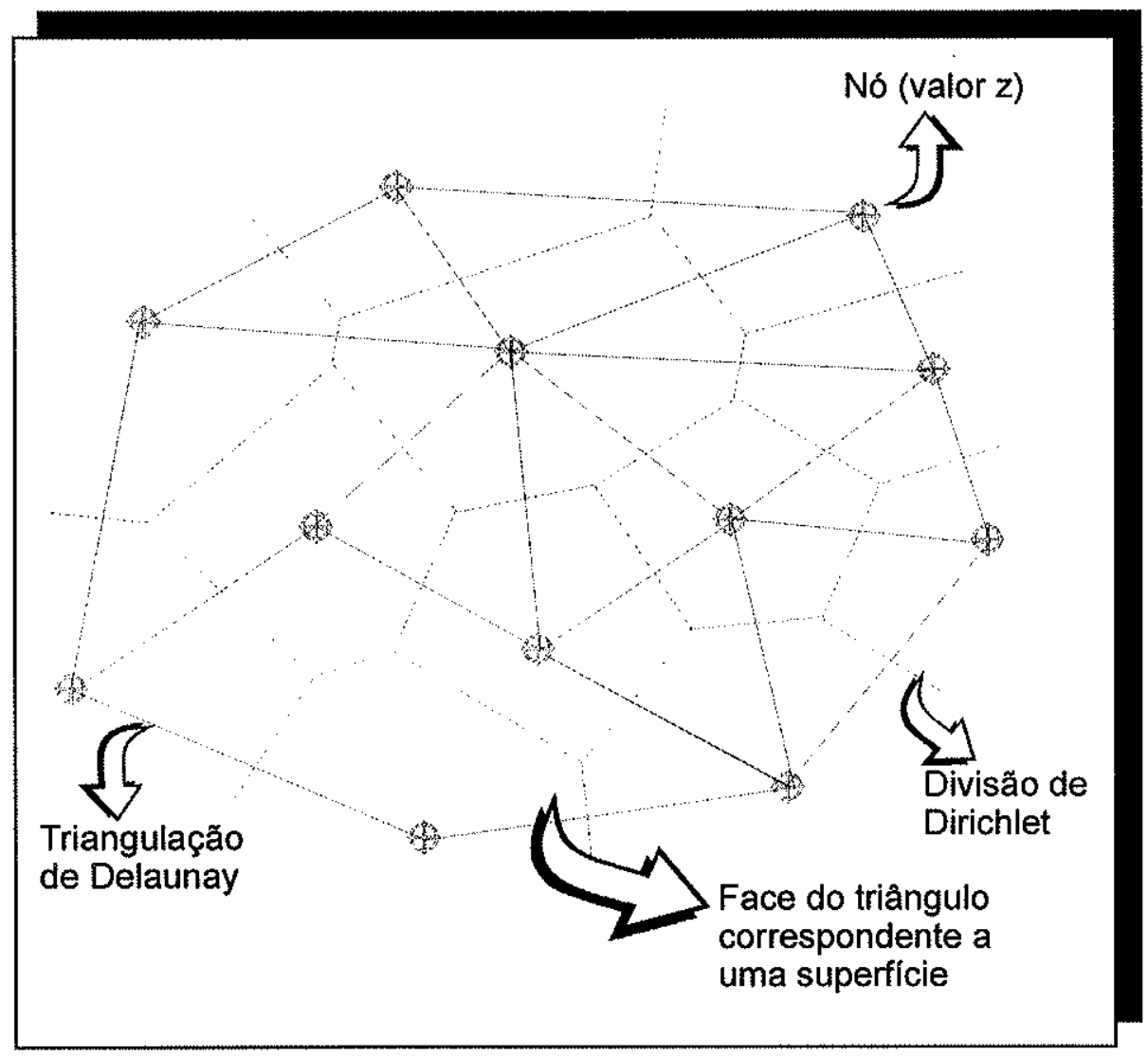

Figura 9: Esquema do modelo numérico de terreno TIN.

O espaço IHS é uma forma alternativa ao espaço RGB. No sistema IHS as cores são definidas a partir de três atributos: intensidade, matiz e saturação. A intensidade pode ser compreendida como a sensação do brilho, a matiz diz respeito às cores de um objeto, e a saturação pode ser entendida como tom, ou seja, um baixo valor corresponde a tons pastéis.

No espaço IHS pode-se alterar um dos atributos sem, no entanto, interferir nos outros dois.

Na tranformação IHS utilizada, o MNT sombreado foi substituído no canal da intensidade (I) e o MNT classificado em cores foi mantido no canal da matiz $(H)$, uma máscara de número digital único foi atribuída ao canal da saturação (S). Após estas substituições os dados foram transformados do espaço de cores IHS para o espaço RGB, para que pudessem ser visualizados. 


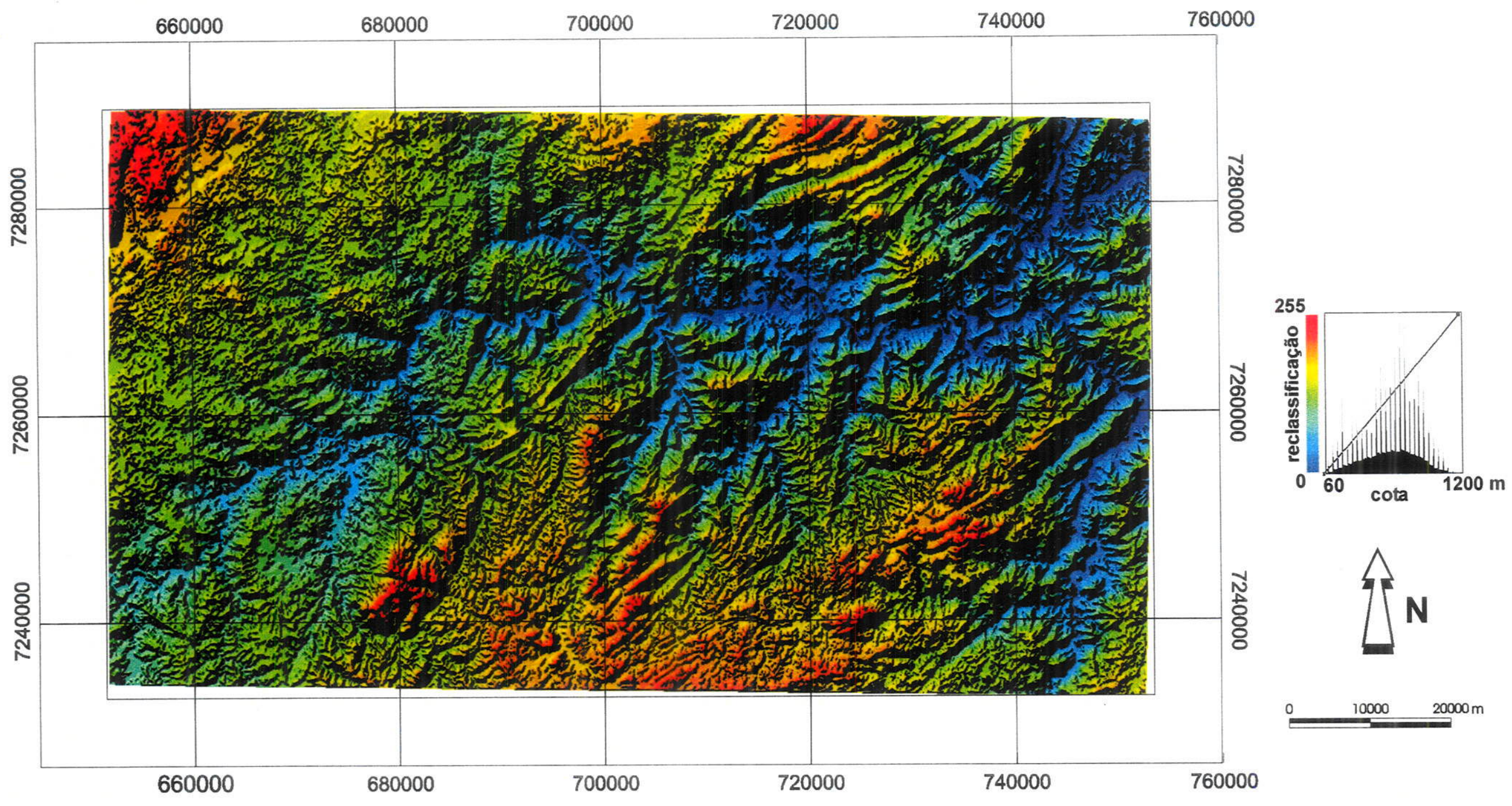

Figura 10: Modelo numérico de terreno - integração IHS com relevo sombreado, iluminação a partir de N45W com inclinação de 45 graus. 


\subsubsection{Dados geoquímicos de sedimentos de corrente}

A análise dos dados geoquímicos de sedimentos de corrente é feita observando-se a distribuição de freqüência cumulativa dos dados e modelando-se a distribuição de freqüência das populações que compõem o conjunto de dados, permitindo, quando for o caso, separar distribuições mistas em suas componentes normais ou lognormais. Esse modelamento é necessário para a definição da população de valores menores, que representa as dispersões normais de distribuição dos elementos analisados nas bacias (background).

Para a separação das populações na área de estudo, seguiu-se a metodologia apresentada por Macedo (1996), que usa a técnica e o programa PROBPLOT (Stanley, 1987) o qual é uma adaptação da técnica de Williams (1967). A partir dos dados formatados foi feita a plotagem dos gráficos de freqüência acumulada para todos os arquivos. Foram separados os conjuntos de dados onde a curva de freqüência acumulada logarítmica demonstrava ser composta por duas populações distintas. Utilizou-se a população de menor média aritmética (considerada background), para se calcular sua média geométrica e desvio geométrico. Para os dados que não era possivel fazer a separação entre populações componentes, foram calculadas a média geométrica e o desvio geométrico para $100 \%$ das amostras.

Williams (1967) propõe a plotagem do conjunto de dados num papel de probabilidade de escala logarítmica. As distribuições bimodais neste caso se caracterizarão pela definição de uma curva em $S$, na região do ponto de inflexão se definirá o valor do limiar. Separam-se as populações e para cada diferente população tem-se uma reta de inclinação diferente.

Segundo Sinclair (1974), o termo limiar (threshold) é utilizado significando um valor específico que, efetivamente, separa valores de dados altos e baixos de caracteristicas fundamentalmente distintas que refletem diferentes causas. $O$ termo limiar é aplicado para valores que distinguem conjuntos de dados superiores ou anômalos, daqueles conjuntos inferiores ou de background.

Segundo Macedo (1996) o valor de limiar mais aceito da população de background é MG.DG². 
Dessa forma, os limiares entre background e anomalia foram calculados utilizando-se o seguinte parâmetro:

\section{limiar da população de background $=M G \times D^{2}$}

onde,

$M G$ = média geométrica

$D G^{2}=$ desvio geométrico ao quadrado

Um exemplo de gráfico plotado no programa PROBPLOT (Stanley, 1987) é apresentado na figura 11, na qual podem ser vistas as retas das populações componentes e os dados de média e desvio padrão das duas populações.

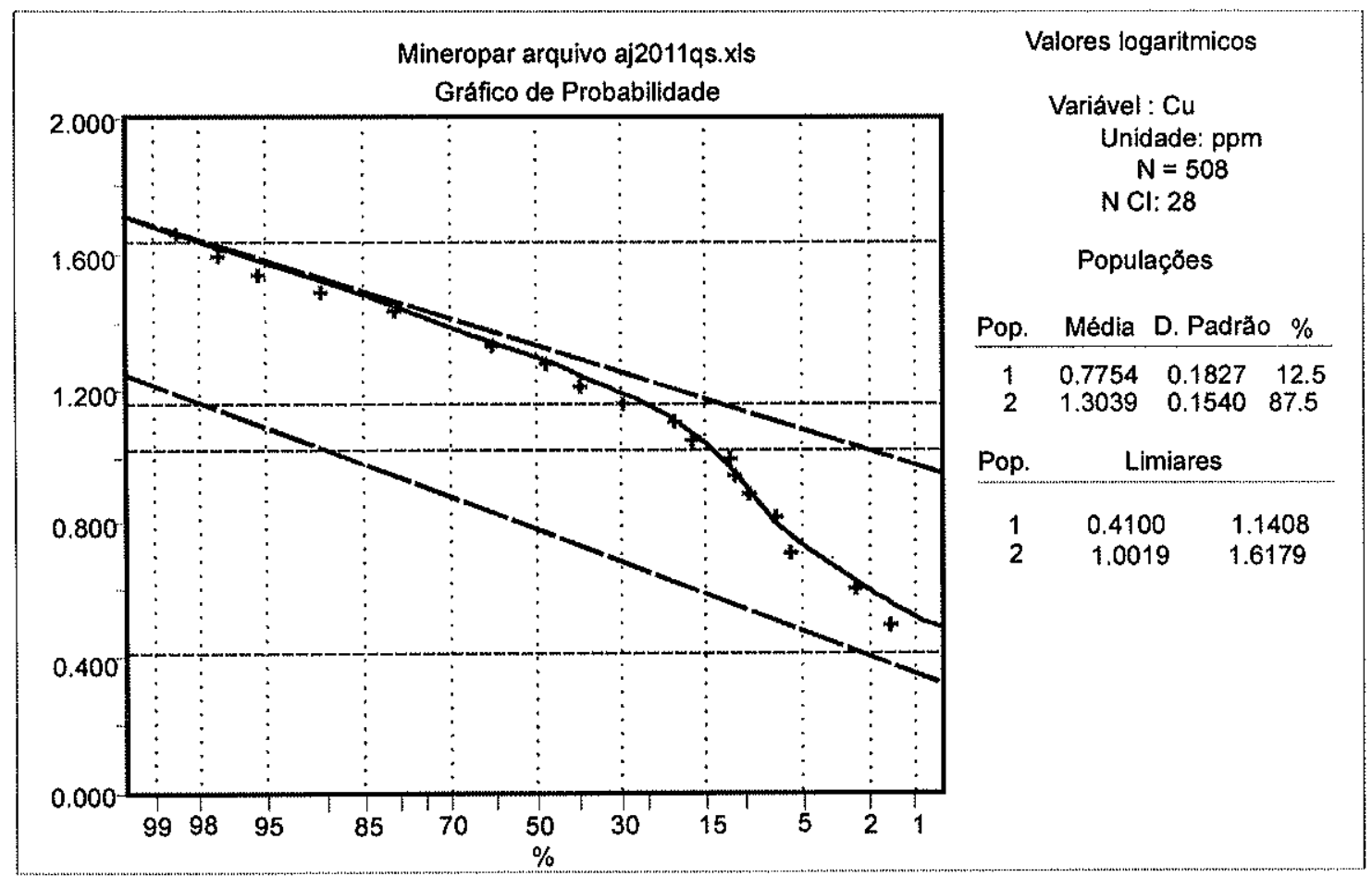

Figura 11: Exemplo de gráfico do programa Probplot aplicado a população de dados de um levantamento geoquímico.

Com o valor de limiar de anomalia calculado pode-se definir o valor de contraste de anomalia para cada amostra. O valor de contraste é obtido dividindose o teor de uma amostra pelo limiar de anomalia, definido para a população de origem da amostra.

O valor de contraste é uma medida relativa, ou seja, é um valor sem dimensão.

Os valores de contraste são úteis para se fazer a comparação de valores, de bacias anômalas e não anômalas, entre dados originários de diferentes populações e diferentes projetos. Nota-se que os pontos não anômalos terão 
valores entre maior que 0 e menor que 1 (adimensional), os pontos anômalos tem valores maiores ou iguais a 1 , de modo que os maiores valores de contraste correspondem às anomalias cujos teores são muitas vezes maiores que 0 background.

A partir do arquivo de pontos com os valores de contraste foram traçadas as bacias a montante de cada ponto amostrado. Este processo foi feito de maneira automática utilizando os aplicativos do programa Arclnfo 7.1.

Para se fazer o traçado automático das bacias amostradas partiu-se de um arquivo vetorial de pontos (chamado coverage no sistema Arclnfo 7.1). Este arquivo de pontos contém todos os pontos amostrados e os respectivos atributos com valores analisados para $\mathrm{Pb}, \mathrm{Zn}$ e $\mathrm{Cu}$, o limiar traçado para cada conjunto de pontos, o valor de contraste e o nome do arquivo de origem. Além dos pontos utilizou-se um modelo numérico de terreno ( $T I N$ - triangulated irregular network) como base para o traçado das bacias.

O primeiro passo foi o de se preencher as menores depressões do modelo numérico de terreno as quais não representam, necessariamente, uma bacia hidrográfica, e que em geral são derivadas do processo de interpolação do modelo. Segundo ESRI (1995), quando uma depressão é preenchida são utilizados os valores da borda desta depressão em toda sua extensão. De modo geral o resultado é o de um modelo numérico onde as pequenas irregularidades são suprimidas. O parâmetro utilizado neste procedimento é o da altura para preenchimento das depressões. O valor adotado foi aquele que permitiu traçar apenas as bacias que interessavam segundo a escala de entrada de dados (digitalização das curvas a partir de mapas na escala 1:50.000), mas que ao mesmo tempo năo ocasionou o preenchimento das bacias que poderiam ser significativas.

A partir do modelo numérico de terreno, com as menores depressões preenchidas, determinou-se a direção de fluxo de cada célula do modelo numérico de terreno (ESRI, 1995). A direção de fluxo é determinada a partir da definição da direção de maior declividade; isto é feito analisando-se a diferença de valores entre células vizinhas considerando-se a distância entre elas. Quando as células são ortogonais utiliza-se o valor igual a 1; quando as células são diagonais utiliza-se o valor igual a $\sqrt{2}$. Se o valor entre células vizinhas for igual 
procura-se a célula adjacente e assim sucessivamente até encontrar-se os valores de maior declividade. As células adjacentes com valores iguais são consideradas como pertencentes a uma mesma bacia (ESRI, 1995).

A partir da grade ( $g r i d$ ) de direção de fluxo determinaram-se as áreas de acumulação de fluxo que podiam ser utilizadas para identificar as drenagens, assim definiram-se valores altos para as áreas de acumulação de fluxo (drenagens) e valores baixos para as áreas que identificam cristas (ESRI, 1995).

$\mathrm{O}$ arquivo de pontos de amostragem é transformado em uma grade (imagem raster). Os pontos que estão fora das drenagens são recolocados, segundo uma tolerância de busca, e considerou-se como base a grade de acumulação de fluxo.

A partir do arquivo de direção de fluxo e do arquivo de pontos recolocados as bacias são traçadas automaticamente. Este aplicativo traça as bacias à montante de um conjunto de pontos de entrada a partir de um arquivo de direção de fluxo (ESRI, 1995).

O processo utilizado para traçar as bacias automaticamente está descrito no fluxograma (figura 12) e a macro-instrução em AML (ARC Macro Language) desenvolvida encontra-se no anexo $\mathrm{I}$.

Traçado automático de bacias a partir de MNT

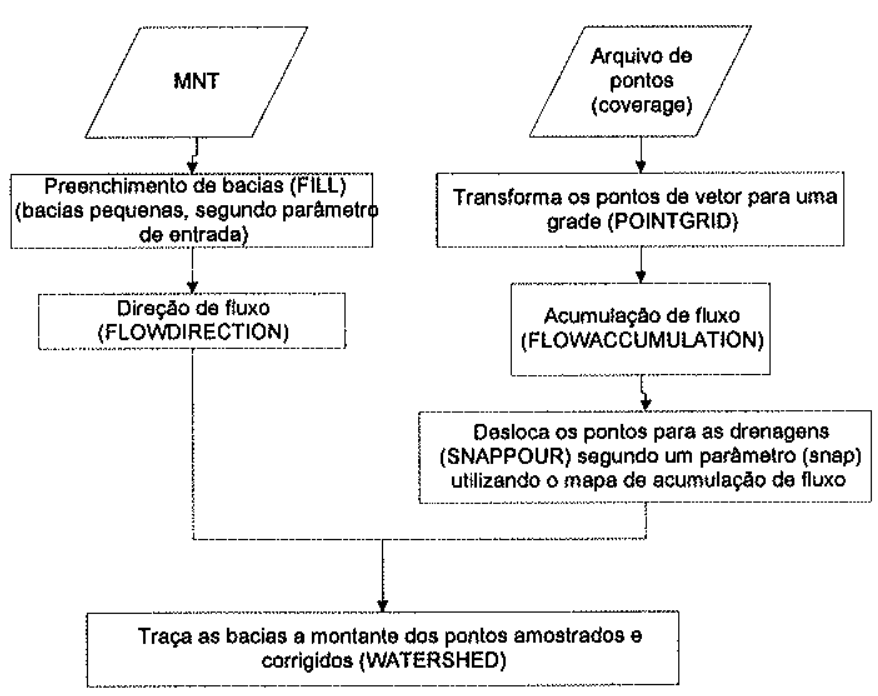

Figura 12: Fluxograma com as principais etapas para traçar bacias de drenagem automaticamente no Arclnfo 7.1 a partir dos pontos de amostragem de sedimentos de corrente e MNT. 


\subsubsection{Dados aerogeofísicos magnetométricos}

Apesar das restrições técnicas apresentadas pelos dados magnetométricos do projeto Serra do Mar Sul (Silva \& Mantovani, 1994) utilizaram-se os dados desse projeto numa integração com o projeto São Paulo - Rio de Janeiro e foram obtidos resultados aceitáveis. Um dos grandes problemas do projeto SMS é o das imprecisões das coordenadas UTM, que variam localmente. Não se procurou corrigir os dados do projeto SMS, pois tais correçōes implicariam na mudança do escopo deste trabalho, optando-se por utilizar os dados com suas limitações.

O primeiro passo, no tratamento dos dados magnetométricos, foi $\circ$ nivelamento dos bancos de dados dos projetos Serra do Mar Sul e São Paulo Rio de Janeiro.

$\mathrm{Na}$ área de estudo, as linhas de vôo têm um recobrimento numa pequena porção na região sul da folha Apiai, 1:100.000 (SG-22-X-B-V). Este recobrimento foi utilizado para definir um valor de correção que seria aplicado a um dos levantamentos.

Primeiramente, procedeu-se à interpolação das grades, utilizando-se o interpolador de mínima curvatura, com uma célula de 700 metros e, posteriormente, foi feita uma reamostragem para 1/4 da distância entre linhas de vôo, ou seja, 250 metros utilizando o interpolador Akima, o qual visualmente forneceu o melhor resultado. O interpolador Akima utiliza o príncipio da triangulação. Segundo Akima (1978 apud Yamamoto, 1986) este interpolador é aplicável quando não há necessidade de suavização dos dados porque a interpolação é exata. $O$ tamanho da célula foi definido conforme os procedimentos descritos para o tratamento dos dados de aerogamaespectrometria (item 3.3.4).

Tanto a imagem derivada dos dados do projeto Serra do Mar Sul (SMS) quanto a imagem derivada dos dados do projeto São Paulo - Rio de Janeiro (SPRJ) foram filtradas. Utilizou-se um filtro cosseno direcional. No caso do SMS utilizou-se uma direção 330 , deixando-se passar as informações nesta direção (opção passa) com grau 4. Já o SPRJ utilizou direção 0, deixando passar as informações nesta direção (opção passa) com grau 4.

Preparou-se uma máscara correspondente à área de sobreposição dos projetos e recortou-se a área de recobrimento das duas imagens. Deste modo 
obteve-se uma imagem recortada para o SMS e uma para o SPRJ exclusivamente com a área de sobreposição dos dois levantamentos. Calculou-se a média da área de recobrimento recortada para o SMS e para o SPRJ. Subtraiuse a média do SPRJ da média do SMS e somou-se esse fator à imagem de menor valor que neste caso foi a imagem do SMS.

Amostraram-se os grids interpolados e filtrados (cosseno direcional) a partir dos pontos das linhas de vôo, de modo que se obteve um banco de dados com os mesmos pontos levantados originalmente no vôo, mas com os valores já filtrados e nivelados. Procedeu-se dessa maneira, tanto para a imagem filtrada do SPRJ quanto para a imagem filtrada e nivelada do SMS. Juntaram-se os bancos de dados e procedeu-se novamente à interpolação de uma imagem única utilizando o interpolador mínima curvatura com tamanho de célula igual a 700 metros e posterior reamostragem para 250 metros.

O procedimento descrito acima teve como objetivo produzir um banco de dados que se preste à interpretação qualitativa das principais feições estruturais e das principais anomalias magnéticas.

A partir do banco de dados com os projetos integrados procedeu-se à geração de uma imagem de redução ao polo, uma de primeira derivada vertical e uma de controle automático de ganho.

As anomalias magnéticas em um mapa com redução ao polo ocorrem verticalmente acima de suas fontes (Gunn et al., 1997) de tal modo que esses mapas são mais simples de se interpretar do que outros onde há inclinação magnética.

Para a redução ao polo dos dados magnéticos da área de estudo utilizaram-se os seguintes parâmetros:

Tabela 19: Parâmetros de redução ao polo dos dados magnéticos

\begin{tabular}{ll}
\hline Coordenada central da área & $49^{\circ} 00^{\prime} 00^{\prime \prime}$ W/ $24^{\circ} 45^{\prime} 00^{\prime \prime} \mathrm{S}$ \\
Periodo & $1^{\circ}$ de março de 1978 \\
Inclinação & $26^{\circ} 17^{\prime}$ \\
Declinação & $14^{\circ} 17^{\prime}$ \\
Intensidade total & 23561 \\
\hline
\end{tabular}

Os parâmetros de redução ao polo foram baseados no mapa magnético do Brasil do IBGE (1990a,b), escala 1:10.000.000. Os elementos utilizados foram: 
declinação, inclinação e intensidade total, que posteriormente foram confirmados utilizando-se o programa ELEMAG, também do IBGE.

O controle automático de ganho é uma técnica que cria uma imagem, na qual todas as anomalias são forçadas a ter aproximadamente a mesma amplitude e as anomalias mais fracas são, em princípio, tão evidentes quanto anomalias intensas (Gunn et al., 1997), de modo que tal imagem é muito útil na interpretação de dados estruturais.

Gradientes verticais de campos magnéticos representam campos magnéticos nos quais os efeitos regionais e a interferência entre anomalias adjacentes foram suprimidos (Gunn et al., 1997), de tal modo que se podem estudar anomalias locais. Considerando tal processamento numa imagem reduzida ao polo, então teremos a possibilidade de estudar uma anomalia local que se encontra sobre sua fonte, o que pode ser muito útil para a prospecção mineral.

\subsubsection{Dados aerogeofísicos gamaespectrométricos}

Para o tratamento dos dados, foi utilizado o programa Oasis Montaj 4.2.

A partir dos dados obtidos do projeto CPRM-BARMP (1997), juntou-se num único banco de dados os projetos Serra do Mar Sul e São Paulo - Rio de Janeiro. Isto foi feito baseado em observações do relatório do CPRM-BARMP (1997), que indica que os procedimentos de processamento dos dados, ou seja, a conversão de cps para ppm, permite o processamento e análise dos dados de diferentes projetos numa mesma grade.

Os dados foram interpolados utilizando-se o interpolador de mínima curvatura com uma célula de $700 \mathrm{~m}$ e posterior reamostragem para célula de 30 $m$ utilizando-se o interpolador Akima.

Após alguns testes com células menores, utilizou-se o tamanho da célula para interpolação de $700 \mathrm{~m}$ devido aos desvios das linhas de vôo do projeto Serra do Mar Sul. Estes desvios causam "vazios" na grade interpolada, já que optou-se por utilizar distância de busca nula. A distância de busca nula foi definida com o intuito de se manter a fidelidade aos dados originais. 
Foi gerada uma grade com célula de $250 \mathrm{~m}$ a partir da reamostragem da célula de $700 \mathrm{~m}$ para cada canal: tório, potássio e urânio.

A partir das grades com os dados dos canais $T h, U$ e $K$ foram calculados para cada canal, as razões $T h / K, U / K$ e U/Th e o parâmetro $F$.

O parâmetro $F$ foi proposto por Efimov (1978 apud Gnojek \& Prichystal, 1985) como K.(U/Th). Segundo Gnojek \& Prichystal (1985) este parâmetro é muito útil em exploração mineral, pois compreende duas características importantes do ambiente rochoso, que são as respectivas abundâncias de potássio e urânio no ambiente, segundo as razões Th/K e Th/U. Gnojek \& Prichystal (1985) verificaram que de modo geral as anomalias de potássio são acompanhadas por urânio variável e por concentrações muito baixas de tório. Ostrovsky (1973) descreve o contraste de comportamento entre o tório e o potássio como o antagonismo tório/potássio, o qual segundo Gnojek \& Prichystal (1985) é típico de processos de alteração acompanhados por um enriquecimento secundário de potássio.

Gnojek \& Prichystal (1985) citam os trabalhos de vários autores a respeito da importância do papel do potássio junto a processos mineralizantes. Entre eles Fojt (1966 apud Gnojek \& Prichystal) destacou a relação entre rochas traquíticas (keratophyric: rochas contendo alto feldspato sódico, comumente associadas com rochas espiliticas e intercaladas com sedimentos marinhos, Bates e Jackson, 1987) ricas em potássio e mineralizações de $\mathrm{Pb}$ e $\mathrm{Zn}$ no nordeste da Morávia. Gnojek \& Prichystal (1985) também descrevem anomalias de potássio relacionadas a um depósito de sulfetos de $\mathrm{Pb}-\mathrm{Zn}$, também, no nordeste da Morávia.

Entre as conclusões de Ostrovsky (1973), destaca-se a possibilidade de se utilizar aerogamaespectrometria na prospecção de alterações hidrotermais ou metassomáticas hidrotermais de rochas magmáticas e 0 antagonismo entre 0 potássio/tório como uma das caracterísiticas geoquímicas das alterações associadas, no caso, com metassomatismo alcalino.

Mares (1984) relaciona o comportamento entre $\mathrm{K}, \mathrm{U}$ e Th, nos depósitos hidrotermais-metassomáticos de elementos não radioativos, baseado no trabalho de Ostrovsky (1974). Segundo Mares (1984), no caso de mineralizações de Cu, 
$\mathrm{Pb}$ e $\mathrm{Ag}$, onde a principal alteração, é a sericitização há um incremento do potássio e um comportamento neutro do urânio.

Mares (1984) afirma que, de modo geral, o conteúdo de potássio diminui em zonas de albitização e silicificação, enquanto aumenta em zonas de feldspatização e sericitização. O Urânio, segundo esse autor, ocasionalmente mostra uma relação positiva com depósitos hidrotermais de $\mathrm{Pb}, \mathrm{Cu}, \mathrm{Zn}$ entre outros.

\subsubsection{Dados de ocorrências minerais}

Baseado no banco de dados inicial, procurou-se primeiramente eliminar as ocorrências duplicadas. Posteriormente, procurou-se a localização de cada ocorrência baseando-se, preferencialmente, em trabalhos acadêmicos e projetos de pesquisa mineral em que as ocorrências eram citadas e apresentadas com mapa de localização.

Entre os projetos utilizados destaca-se a contribuição do projeto Mapas Metalogenéticos o qual apresenta uma base de dados com descrição de características de interesse da ocorrência, como: substância mineral, litologia encaixante, status mineral (ocorrência, jazida, etc), nome do local, morfologia e principalmente coordenadas geográficas.

Cassedane (1972) organizou um grande número de ocorrências na área de estudo. Contudo, os mapas de localização apresentados não têm qualquer sistema de projeção e as tabelas de ocorrências não citam a localização dos pontos, apenas o nome da mineralização e o nome do local. Isto também ocorre no trabalho de Melcher (1968). Apesar das limitações apresentadas esses dois trabalhos são muito importantes na definição da posição relativa das ocorrências.

Cada ocorrência foi conferida e eliminaram-se aquelas cuja localização fosse duvidosa. Dessa maneira procurou-se manter apenas aqueles dados que fossem consistentes com os estudos já feitos na região. Assim, de um total de 479 pontos de possiveis ocorrências levantados a partir do CPRM-Microsiga (1994) e MMAJJICA $(1981,1982,1983)$ e IDEM (Figueiredo, 1988) obteve-se um banco de dados com 113 ocorrências conhecidas e observadas na literatura. Procurou-se corrigir a localização de cada ocorrência contando com as limitações inerentes a este tipo 
de trabalho. Estas limitações estão relacionadas principalmente à falta de precisão e exatidão dos dados encontrados na bibliografia, ou seja, muitas vezes as ocorrências são apresentadas com coordenadas erradas, ou mesmo ausentes. Para contornar estes problemas procurou-se, a partir dos trabalhos mais antigos, corrigir e confrontar a posição das ocorrências, baseada em sua disposição relativa apresentada em diferentes trabalhos.

Foi feita uma separação das ocorrências considerando duas tipologias, tipo Panelas (mineralizações filonares) e tipo Perau (mineralizações estratiformes), por exclusão obteve-se um terceiro grupo de ocorrências que não pertenciam a nenhuma das tipologias acima. O mapa com as ocorrências e a respectiva tabela de atributos encontram-se no anexo III.

\subsubsection{Dados de fraturamento}

O termo fratura, segundo Ramsay \& Huber (1987), é definido como um plano de ruptura onde a coesão na rocha foi perdida, este plano pode corresponder às juntas ou falhas. As juntas são definidas como planos de quebra onde os dois lados do plano não sofreram deslocamento apreciável. A falha é definida quando há deslocamento apreciável.

Segundo Soares \& Fiori (1976), as zonas de fraturamento, por serem mais facilmente atacadas pelos processos meteóricos e erosivos, constituem zonas de desenvolvimento preferencial de linhas de drenagem retilíneas. Aos elementos de drenagem fortemente estruturados (disposição regularmente ordenada), retilíneos ou em arco, denomina-se, segundo Soares \& Fiori (1976), lineações de drenagem e estas são interpretadas como traços de fratura.

Resumidamente conclui-se, segundo Soares \& Fiori (1976), que as fraturas (ou juntas) são refletidas através dos traços de fratura ou lineações de drenagem retilíneas. Os traços de fratura correspondem a zonas de concentração de juntas.

Lattman \& Matzike (1961 apud Soares \& Fiori, 1976) consideram o valor de $1.600 \mathrm{~m}$ para o limite máximo do tamanho do traço. Northfleet et al. (1971) estabelecem o limite em $3.500 \mathrm{~m}$. Segundo Soares \& Fiori (1976), a partir deste limite, as fraturas sofrem deslocamentos como blocos. 
Plicka (1974) define zonas de juntas como zonas de concentração de fraturas mais ou menos paralelas. Segundo o autor, na maioria dos casos, ocorrem dois sistemas perpendiculares entre si. A largura dessas zonas de juntas varia de 0,5 a $6 \mathrm{~m}$. As juntas nestas zonas tem um mergulho de 70 a $90^{\circ}$, e as zonas estendem-se por grandes áreas. As zonas de juntas de qualquer sistema ocorrem repetidamente em distâncias de poucos metros a dezenas de metros entre $\mathrm{si}$, desta forma constituindo um conjunto de zonas de junta. O termo "conjunto de zonas de juntas" é, definido por Plicka (1974), como uma série de zonas de juntas paralelas entre si e com uma gênese comum.

Destacam-se dos trabalhos de Plicka (1974) e Nickelsen (1974) características importantes das zonas de juntas que podem ser utilizadas na prospecção de mineralizações filonares como:

- os conjuntos de zonas de juntas podem emergir de rochas mais antigas e se estender verticalmente através de rochas sobrejacentes mais novas;

- os padrões de fraturamento são cumulativos e persistentes;

- alguns conjuntos de zonas de juntas, representados por grandes lineamentos têm persistido desde o Pré-Cambriano, afetando a sedimentação, a tectônica, a expressão fisiográfica e até mesmo a localização de depósitos minerais.

Segundo Veneziani (1987), a distribuição generalizada e por grandes distâncias mostra que os conjuntos de zonas de juntas são feições geológicas de significado regional, essencialmente independentes de variações litoestratigráficas locais e da atitude dos estratos, embora estes dois últimos fatores exerçam controle sobre a freqüência.

Baseando-se em metodologia de Veneziani (1987), a partir de um mapa com as curvas de isodensidade de fraturamento, ou mesmo uma grade com a freqüência de fraturamento, pode-se interpretar um mapa de eixos de distribuição de fraturamentos na superfície. Segundo Aliyev (1979), estes eixos representam direções de fraqueza precedentes à instalação dos sistemas de fraturas, generalizadamente observados e, conseqüentemente, influem e favorecem um acréscimo na densidade de fraturamentos de gerações posteriores, ao longo dos mesmos. 
$\mathrm{Na}$ interpretação consideraram-se os trechos retilíneos de canais de drenagem como elementos de interesse, já que as drenagens estabelecem-se preferencialmente sobre as linhas susceptiveis à maior erodibilidade, como as zonas de juntas e fraturas.

Utilizou-se $3 \mathrm{~mm}$ como valor mínimo do comprimento do traço para interpretação de feição retilínea na escala 1:250.000, o que equivale a $750 \mathrm{~m}$. Este valor visou a interpretação regional das zonas de fraturamento.

Analisou-se a freqüência de traços por área. O método de cálculo desta freqüência é baseado na contagem do número de traços em uma grade regular de amostragem, considerando-se os traços como aproximadamente padronizados em um mesmo comprimento. Segundo Beisl (1996), a grade regular de amostragem pode ser definida a partir do comprimento médio e desvio padrão das feições lineares extraídas das drenagens, neste caso o valor foi de 753,69 +/$151,23 \mathrm{~m}$, deste modo, a grade regular de amostragem poderia ter um valor de $900 \mathrm{~m}$. Contudo, optou-se por aplicar diversos tamanhos de grade de amostragem, visando-se definir, empiricamente, qual o melhor tamanho de grade para a interpretação visual posterior. Utilizaram-se grades de 750, 1.000, 2.000, $3.000,4.000$ e $5.000 \mathrm{~m}$ de lado. Definiu-se a grade de $3.000 \mathrm{~m}$ para a amostragem dos dados. Baseados na roseta dos traços levantados definiram-se 5 direções preferenciais de zonas de juntas que são as seguintes: N60W, N30W, NS, N45E e N70E. Os traços foram filtrados utilizando-se uma tolerância de busca de $10^{\circ}$, sendo então feita a amostragem. A partir da contagem dos traços, podese visualizar as áreas de maior freqüência de fraturamento segundo as direções definidas, contudo foi obtida uma melhor visualização dos valores de contagem a partir da reamostragem destes dados para uma célula de aproximadamente 300 $m$ de lado. A imagem derivada desta interpolação foi utilizada na interpretação dos eixos de distribuição de freqüência máxima dos fraturamentos.

Segundo metodologia apresentada em Crepani (1987), na análise dos mapas de isofreqüência consideram-se as seguintes observações:

- a quantidade de zonas de juntas aumenta em relação à proximidade de falhas, indicando uma associação genética e geométrica entre as falhas e os conjuntos de zonas de juntas; 
- lineamentos antigos tendem a condicionar a freqüência das zonas de juntas formadas em regiões submetidas a processos de reativação.

Segundo Crepani (1987), o eixo maior das figuras elípticas presentes nas curvas de isofreqüência de densidades máximas de zonas de juntas é uma evidência da presença de linhas de fraqueza da crosta no local.

Santos (1986) justifica a utilização do tratamento estatístico dos dados de fraturamento baseado na premissa de que uma fratura é uma zona de fraqueza e, portanto, uma zona potencial no condicionamento da distribuição dos eventos rupturais posteriores que afetaram a região. Deste modo, a análise das principais direções de fraturamento pode indicar as principais zonas de fraqueza que condicionaram o desenvolvimento tectônico posterior que afetou a região. 


\section{RESULTADOS OBTIDOS}

\subsection{Dados geoquímicos}

Após a conclusão da montagem do banco de dados geoquímicos de sedimentos de corrente, obteve-se um mapa temático com todas as bacias amostradas na área e um conjunto de atributos relacionados a estas bacias. $O$ conjunto de atributos compreende as seguintes informações: valor em ppm atribuído à bacia amostrada para cobre, chumbo e zinco quando disponivel, valor do limiar para os três elementos e valor.

Para uma melhor apresentação e integração dos resultados optou-se por utilizar as bacias com os valores de contraste. Os valores de contraste podem ser utilizados para comparação entre os diversos projetos e desta maneira são mais adequados para a interpretação e análise dos dados.

Os dados apresentados nas figuras 13,14 e 15 sofreram a seguinte reclassificação: para as áreas não anômalas optou-se por um único valor atribuído a todas as bacias, para as bacias anômalas foi feito uma reclassificação para 5 classes, necessária devido à grande dispersão dos valores de contraste. $O$ valor destas classes foi definido de modo que todas as classes de anomalias tenham um valor aproximadamente igual. Esta reclassificação foi feita com objetivo único de melhorar a visualização dos dados, não sendo utilizada na análise de favorabilidade, discutida no capítulo "Integração de dados e seleção de áreas favoráveis". 


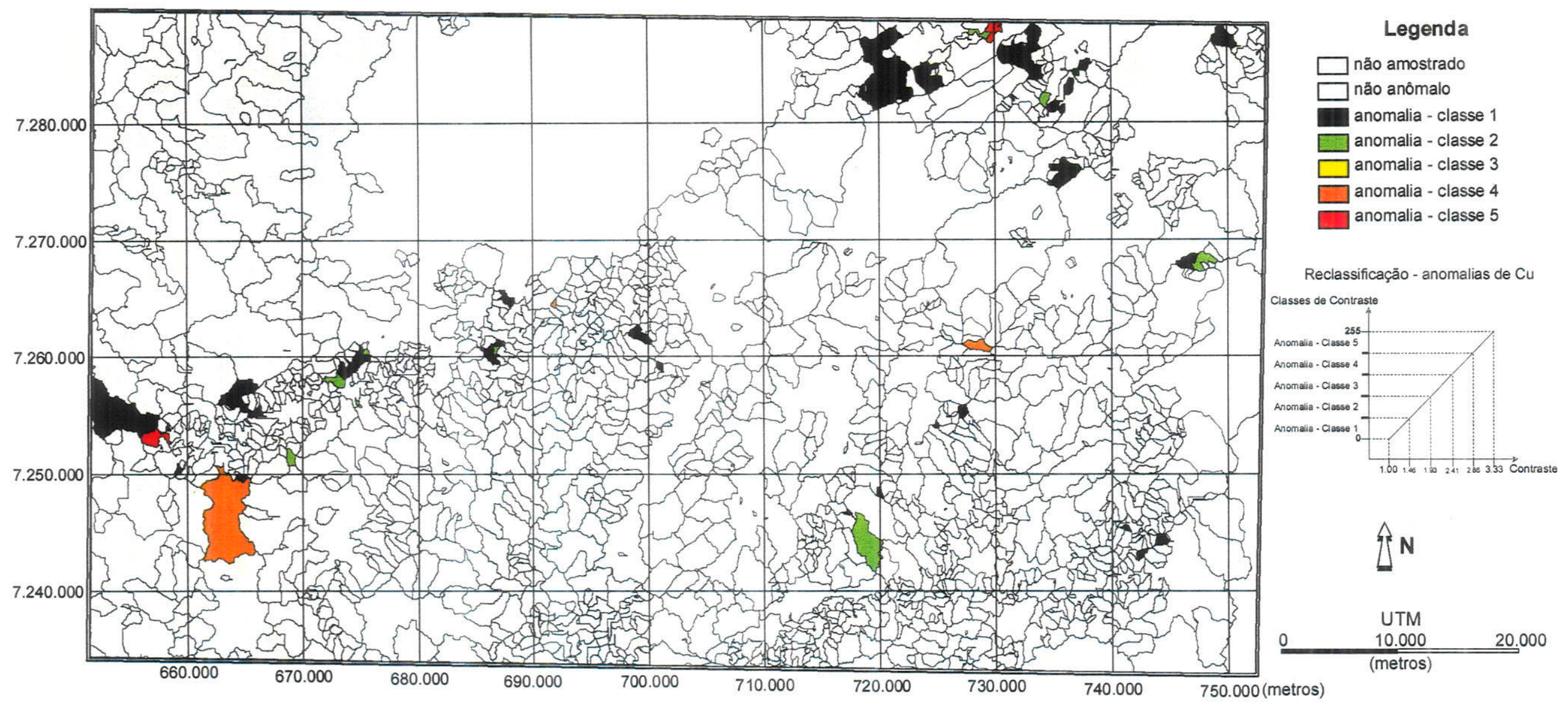

Figura 13: Bacias anômalas - sedimentos de corrente - Cobre. 


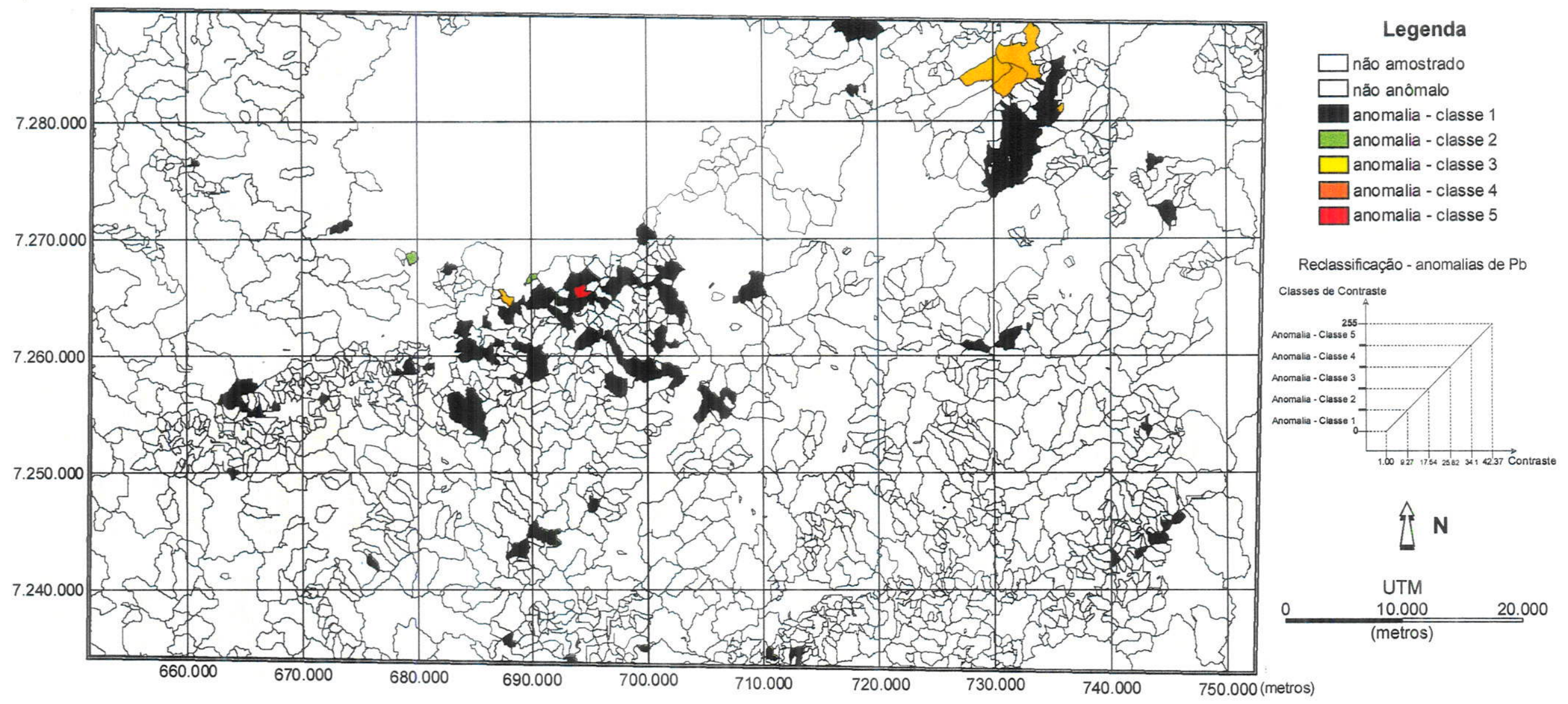

Figura 14: Bacias anômalas - sedimentos de corrente - Chumbo. 


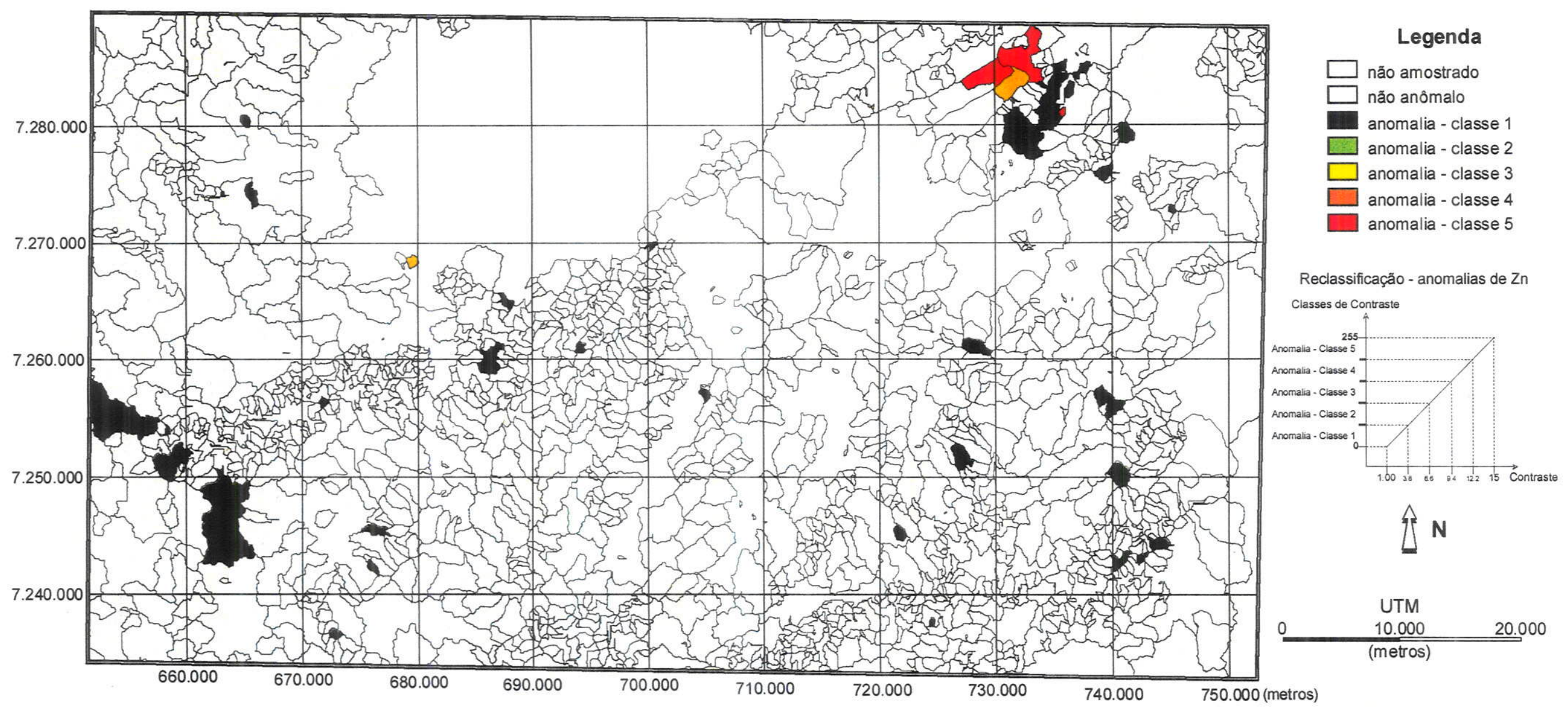

Figura 15: Bacias anômalas - sedimentos de corrente - Zinco. 


\subsection{Dados aerogeofísicos}

\subsubsection{Magnetometria}

Após a execução das correções (nivelamento entre projetos) e tratamento (redução ao polo, primeira derivada vertical e controle automático de ganho) dos dados brutos foi feita integração entre estes dados, utilizando-se uma técnica conhecida como transformação IHS (vide explicação da técnica no item 3.3.1), visando a interpretação dos dados magnetométricos.

A interpretação dos dados magnetométricos considerou os seguintes elementos:

- lineamentos magnéticos - caracterizados por descontinuidade magnética eventualmente relacionada às falhas, eixos de dobras, entre outras possiveis estruturas tectônicas lineares. Os lineamentos magnéticos também foram traçados ao longo de descontinuidades magnéticas marcadas por limites texturais;

A partir da interpretação magnética, foi verificada a mesma tendência regional NE-SW observada na geologia. As rochas intrusivas aparecem bem delineadas e são moderadamente magnéticas. Da mesma forma, como observado, no projeto Anta Gorda (MMAJ-JICA, 1981) não foi verificada uma relação clara entre as mineralizações $e$ as áreas fortemente magnéticas. Observou-se, principalmente na imagem de primeira derivada vertical, uma relação direta entre estruturas tectônicas e os lineamentos magnéticos.

A interpretação dos dados aeromagnéticos é apresentada e também utilizada na análise a partir de um mapa de lineamentos magnéticos e um mapa de áreas de altos magnéticos e dipolos, como pode ser visto nas figuras $16,17 \mathrm{e}$ 18. 


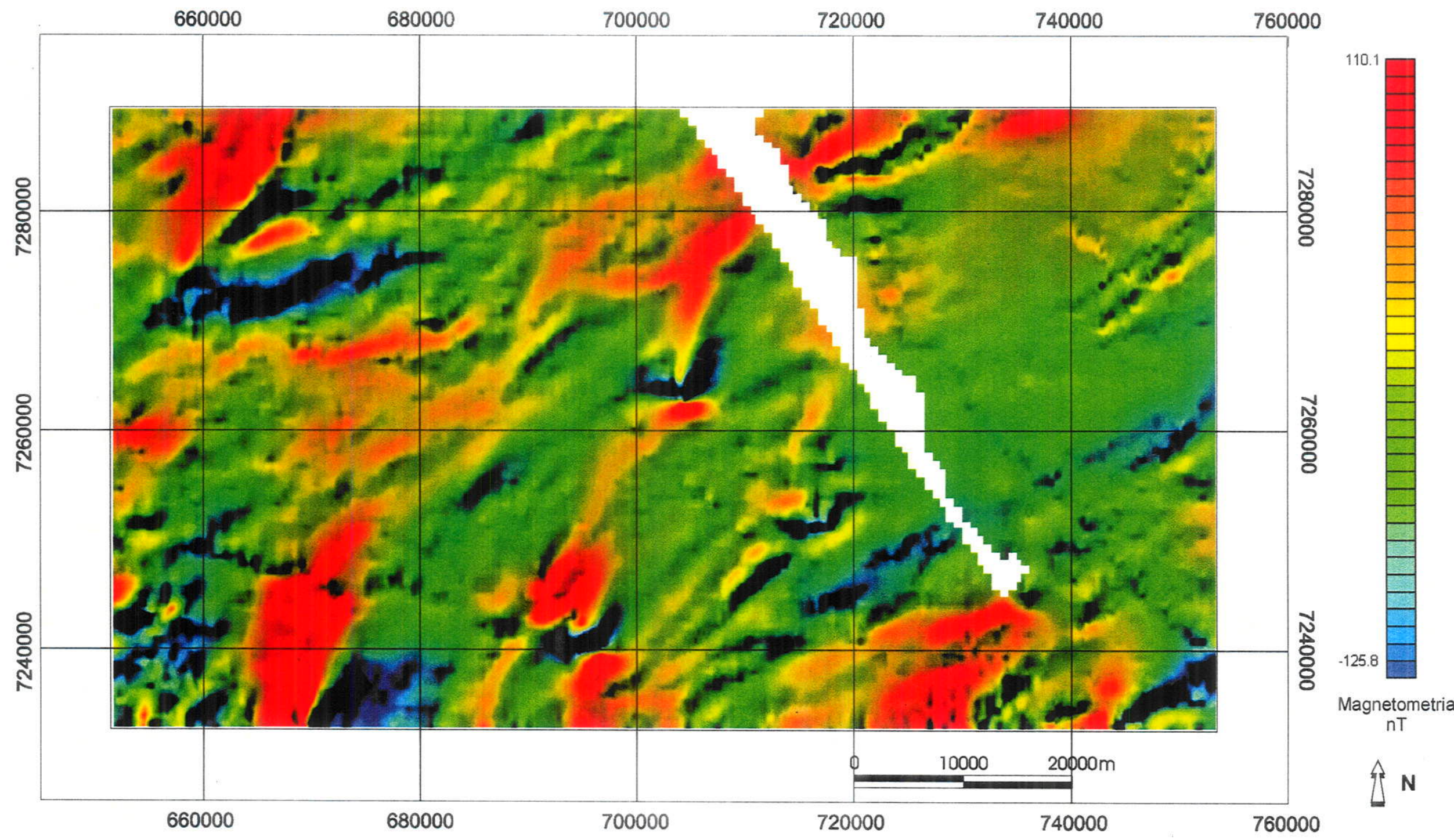

Figura 16: Integração IHS - Magnetometria reduzida ao polo com primeira derivada vertical da magnetometria. 


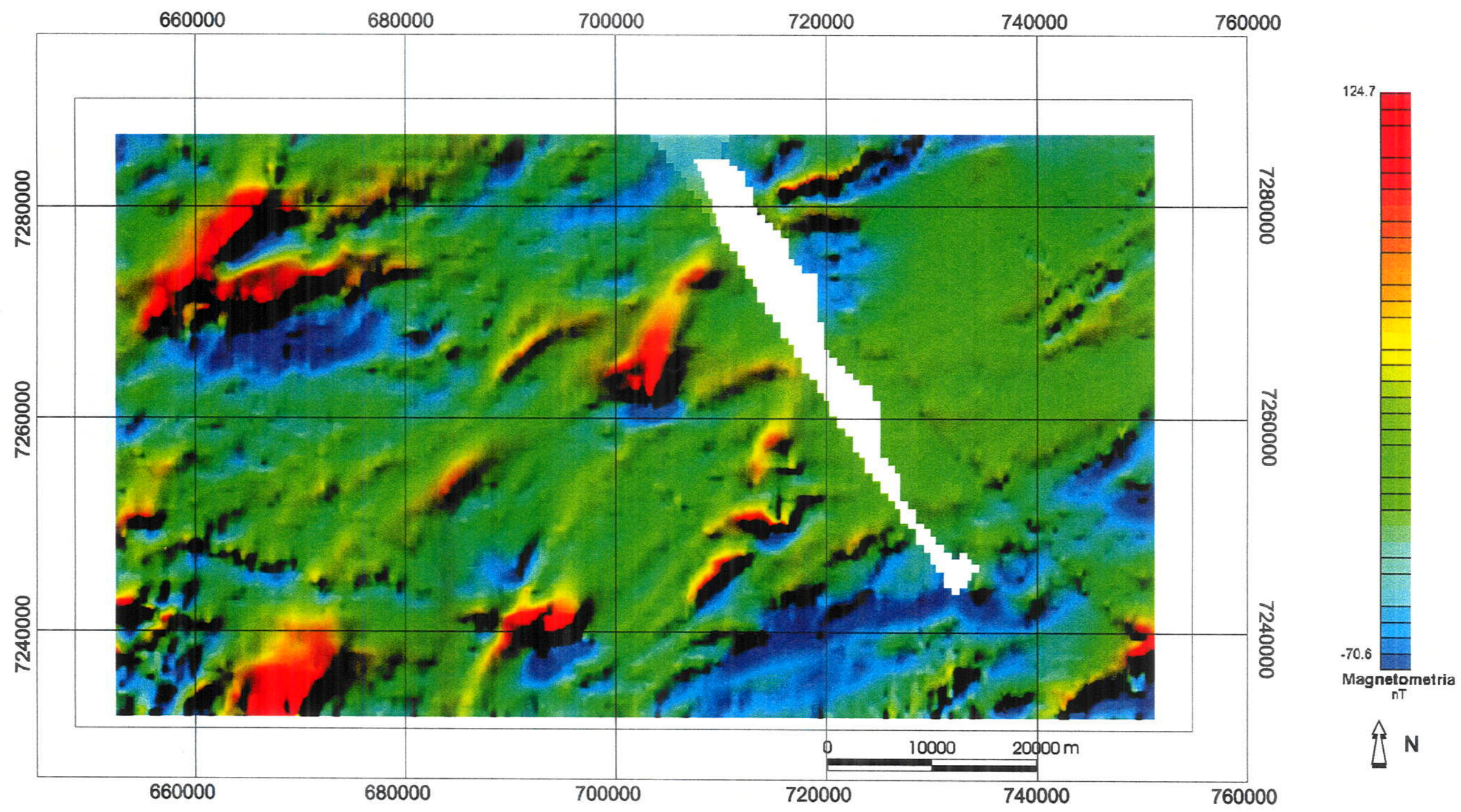

Figura 17: Integração IHS entre primeira derivada vertical da magnetometria e magnetometria sem tratamento. 


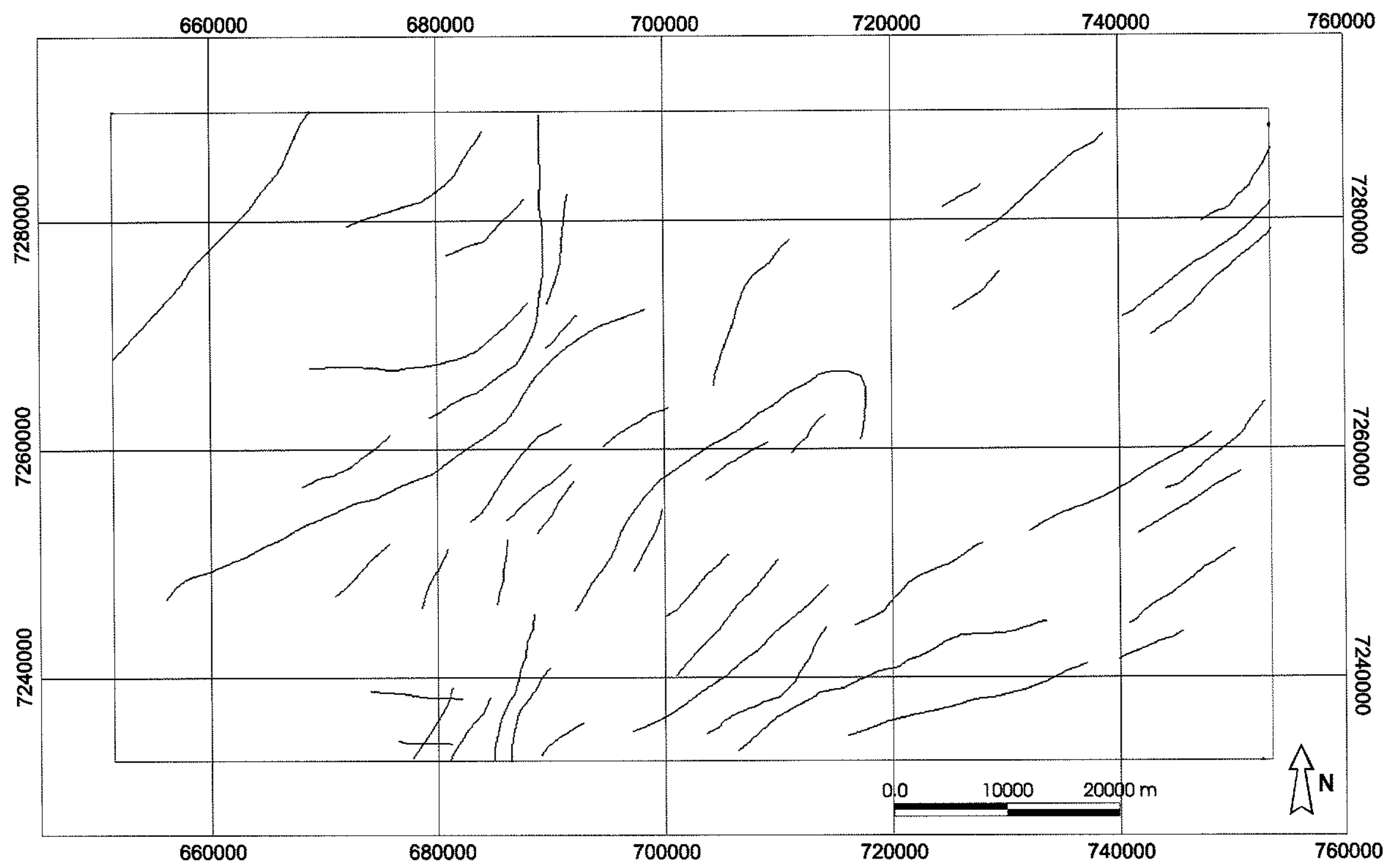

Figura 18: Lineamentos magnéticos interpretados. 


\subsubsection{Gamaespectrometria}

Apesar do nivelamento realizado pelo projeto CPRM-BARMP (1997) verificaram-se, ao integrar o banco de dados dos levantamentos Serra do Mar Sul e São Paulo-Rio de Janeiro, diferenças em relação aos valores médios das duas áreas, como pode ser observado nas figuras 19 e 20, especialmente no canal do tório e do urânio. Com 0 intuito de verificar uma possível relação da gamespectrometria com as mineralizações foram calculadas as razões $T h / K, U / K$, $\mathrm{U} / \mathrm{Th}$, o parâmetro $\mathrm{F}$ e a normalização pelo canal do tório.

Tanto o procedimento baseado no parâmetro $\mathrm{F}$ quanto o procedimento de normalização pelo canal do tório caracterizam-se por relacionar zonas de alteração hidrotermal ao canal do potássio, ou ainda, por corrigir a distribuição das anomalias no canal do potássio, o qual, em geral, mostra muitas áreas com valores altos, em função da grande mobilidade do potássio. A busca de áreas anômalas em potássio, na região, no caso das mineralizações tipo Panelas foi baseada nas caracteristicas destas mineralizações, as quais podem apresentar alterações hidrotermais ligadas ao processo mineralizador. No caso das mineralizações tipo Perau baseou-se na possibilidade, embora remota, das rochas félsicas, ou outras rochas vulcânicas, presentes nas áreas mineralizadas gerarem anomalias aerogamaespectrométricas no canal do potássio.

Optou-se pela utilização dos dados gamaespectrométricos devido às seguintes razões: maior capacidade dos sistemas computacionais atuais; técnicas de tratamento ainda não utilizadas nos dados da área (fator $F$, normalização pelo Tório) e dados gamaespectrométricos convertidos de cps para ppm.

Foi feita uma correlação espacial entre as ocorrências minerais e as imagens obtidas segundo os processamentos descritos anteriormente, contudo não se obteve um resultado positivo no sentido de relacionar os dados gamaespectrométricos e as mineralizações, seja com o tipo Panelas ou com o tipo Perau. Tanto no caso das mineralizações filonares (tipo Panelas), quanto nas estratiformes (tipo Perau) verificou-se que não há citações na literatura descrevendo resultados expressivos na utilização de gamaespectrometria no Vale do Ribeira. 
A principal consideração acerca da falta de correlação entre as mineralizações e os dados gamaespectrométricos utilizados diz respeito à dimensão dos halos de alteração hidrotermal no caso do tipo filonar. Estes halos têm dimensão centimétrica (Daitx et al., 1995) e possivelmente a anomalia de potássio envolvida não seria suficiente para causar alterações radiométricas em um levantamento feito a 150 metros de altura e com espaçamento de 1000 metros entre as linhas de vôo. Da mesma forma conclui-se que o potássio contido nas rochas vulcânicas, associadas às mineralizações estratiformes, também não seria detectado. 
Tório

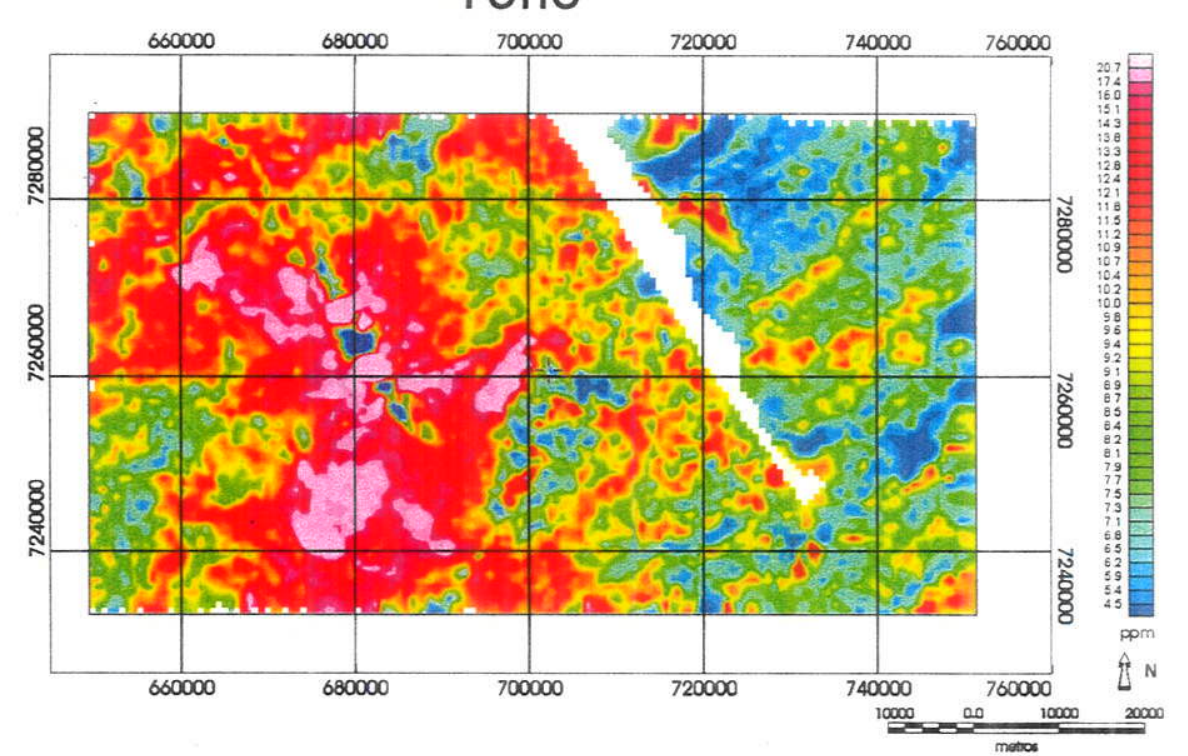

\section{Potássio}

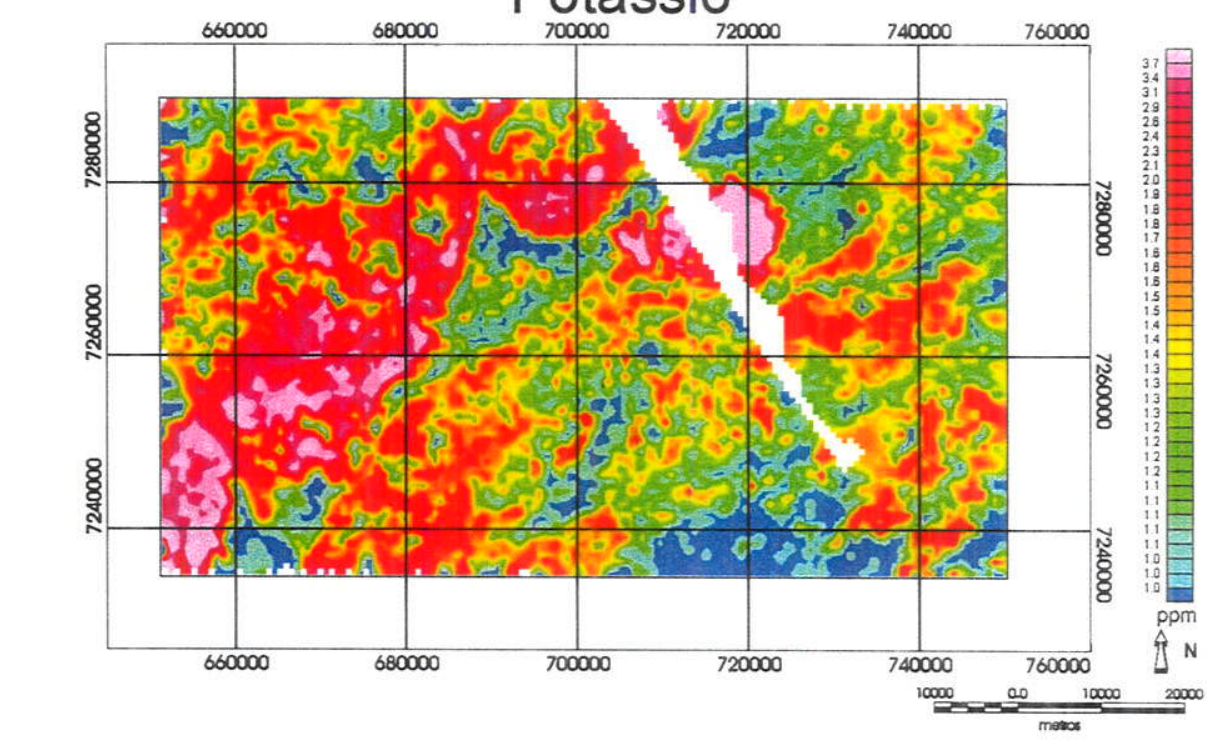

Urânio

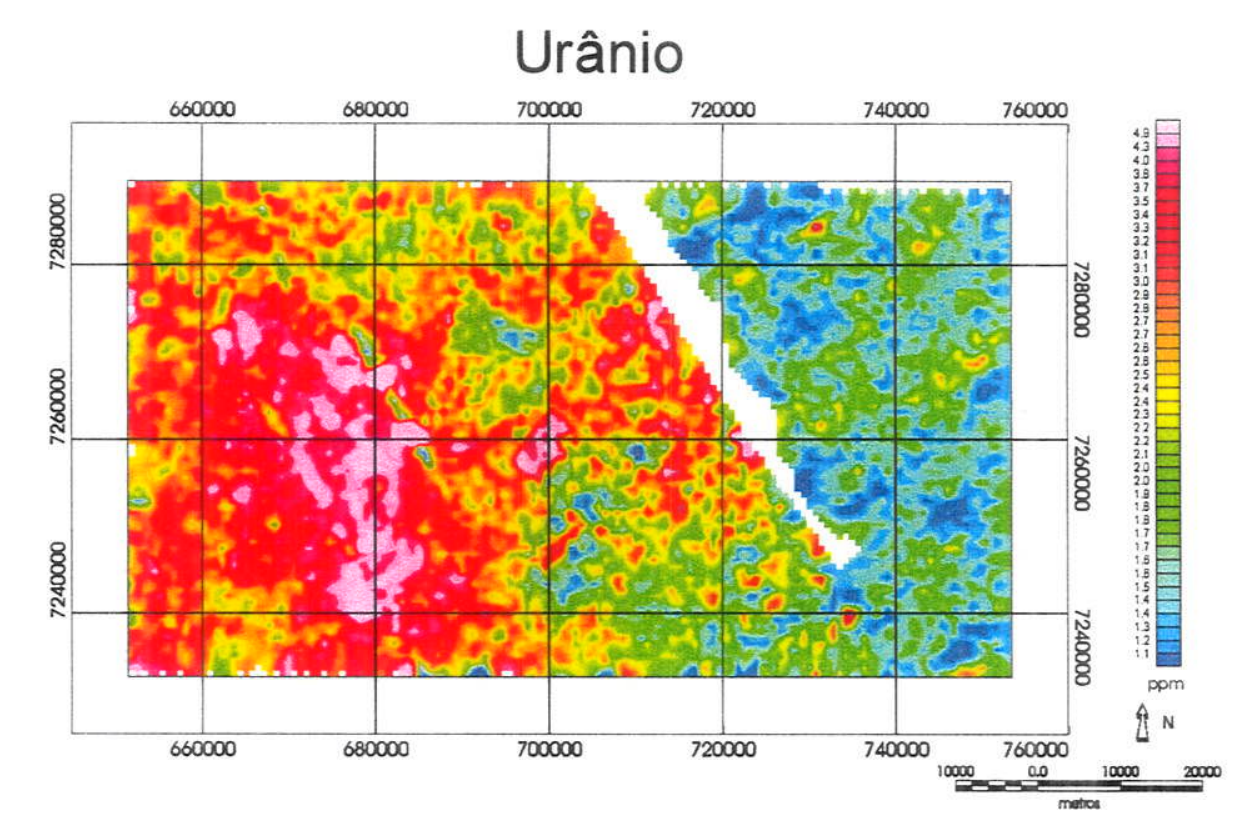

Figura 19: Mapas de distribuição de teores, em ppm, nos canais aerogeofísicos gamaespectrométricas: tório, urânio e potássio. 

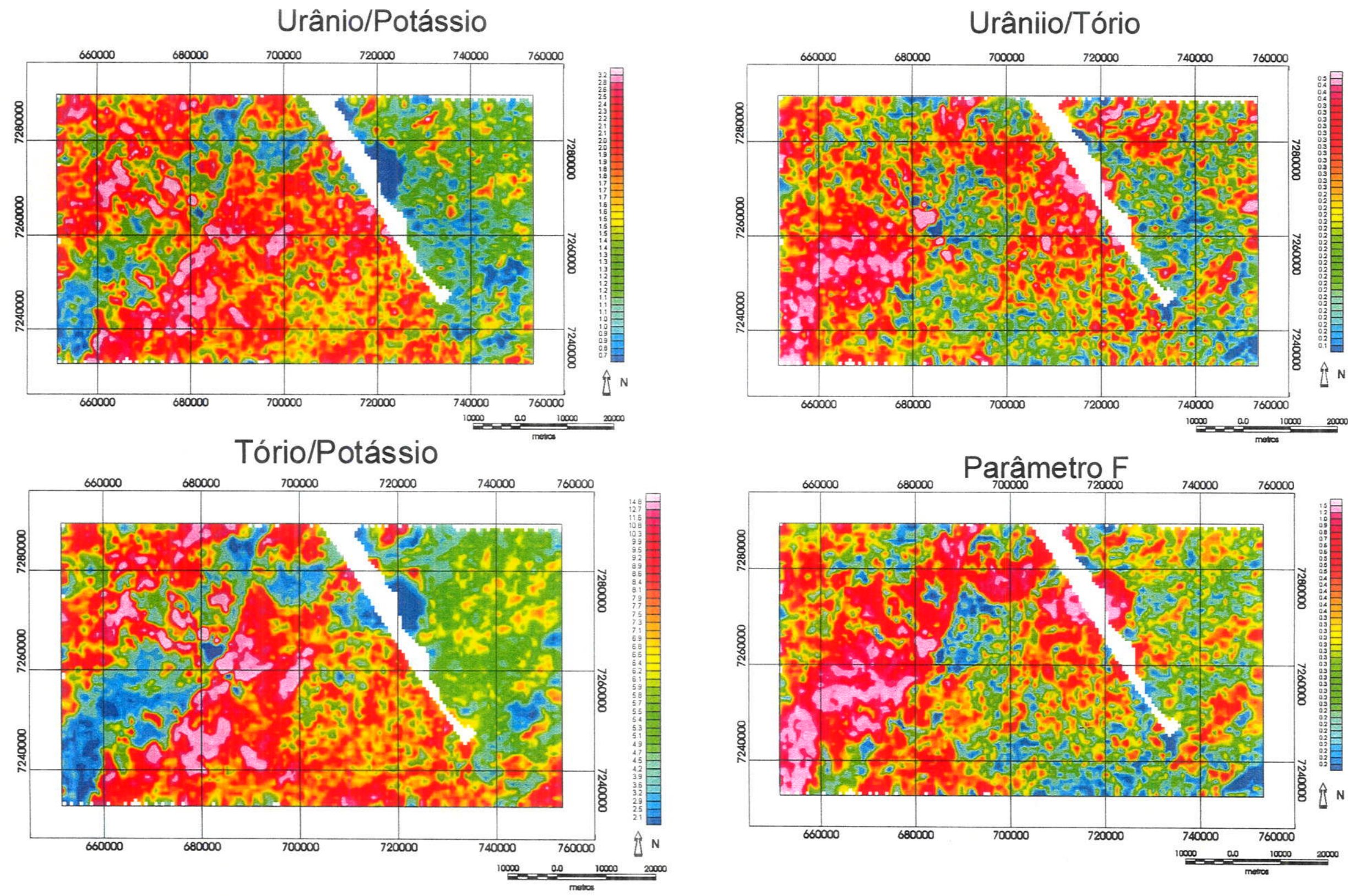

Figura 20: Mapas de distribuição de valores das razões U/K, U/Th, Th/K e parâmetro $F$. 


\subsection{Dados de ocorrências minerais}

No anexo III encontram-se o mapa e a tabela de atributos de ocorrências minerais de sulfetos de chumbo, zinco e cobre na área de estudo.

A grande maioria das ocorrências verificadas (mais de $60 \%$ ) é do tipo Panelas; o tipo Perau conta com menos de uma dezena de ocorrências.

$\mathrm{Na}$ tabela abaixo, verificam-se os valores de teor e recursos geológicos dos principais depósitos da área de estudo. Cabe ressaltar que, atualmente, não há minerações extraindo sulfetos metálicos na região.

Tabela 20: Recurso Geológico "in situ" - Depósitos tipo Perau

\begin{tabular}{lcc}
\hline Mina & Recurso Geológico "in situ" (t) & Teores \\
\hline Perau & 3.100 .000 & $4,04 \% \mathrm{~Pb} ; 1,13 \% \mathrm{Zn} ; 57 \mathrm{ppm} \mathrm{Ag}$ \\
Canoas & 1.400 .000 & $3,1 \% \mathrm{~Pb} ; 3,5 \% \mathrm{Zn} ; 63 \mathrm{ppm} \mathrm{Ag}$ \\
Azurita (Área Faria) & 181.420 & $2,2 \% \mathrm{Cu}$ \\
\hline
\end{tabular}

(Modificado de Daitx, 1996)

Tabela 21: Recurso Geológico "in situ" - Depósitos tipo Panelas

\begin{tabular}{|c|c|c|c|}
\hline \multicolumn{2}{|l|}{ Mina } & Recurso Geológico "in situ" (t) & Teores \\
\hline \multicolumn{2}{|c|}{ Paqueiro } & 1.800 & $5 \% \mathrm{~Pb}$ \\
\hline & Basseti & 169.505 & $4,84 \% \mathrm{~Pb}$ \\
\hline & São Francisco & 19.051 & $4 \% \mathrm{~Pb}$ \\
\hline \multirow[t]{3}{*}{ Rocha } & Matão I & 23.905 & $5,68 \% \mathrm{~Pb}$ \\
\hline & Matão II & 4.916 & $3,35 \% \mathrm{~Pb}$ \\
\hline & Total & 217.377 & $4,82 \% \mathrm{~Pb}$ \\
\hline \multicolumn{2}{|c|}{ Furnas } & 104.028 & $6,6 \% \mathrm{~Pb}$ \\
\hline \multicolumn{2}{|c|}{ Panelas } & 86.834 & $4,15 \% \mathrm{~Pb}$ \\
\hline \multicolumn{2}{|c|}{ Barrinha } & 80.000 & $8,33 \% \mathrm{~Pb}$ \\
\hline \multicolumn{2}{|c|}{ Cecrisa } & 74.946 & $2,96 \% \mathrm{~Pb}$ \\
\hline
\end{tabular}

(Modificado de Daitx, 1985)

* Reserva medida + indicada, dados de reserva inferida não disponíveis

Cox \& Singer (1986) apresentam um sumário de dezenas de depósitos minerais, agrupados segundo características comuns. Os autores apresentam a montagem de um grupo considerável de modelos de depósitos minerais, os quais permitem comparar as características de uma determinada mineralização segundo as observações de diferentes geólogos em diferentes minas e distritos minerais. Basicamente o trabalho contém um modelo descritivo e um modelo de teor e tonelagem para diversos tipos de depósito. No caso do modelo prospectivo Perau utilizou-se o modelo sedex apresentado por Cox \& Singer (1986), para o modelo prospectivo Panelas não foi escolhido nenhum dos modelos apresentados, pois este modelo não foi correlacionado a nenhum modelo genético/descritivo específico conhecido mundialmente. 
Os modelos de teor e tonelagem são apresentados na forma de gráficos, os quais contém no eixo $\mathrm{X}$ o teor ou a tonelagem e no eixo $\mathrm{Y}$ a freqüência acumulada de depósitos. Os autores utilizaram tonelagens estimadas associadas com os menores teores de corte. Curvas suavizadas são traçadas ao longo dos pontos que correspondem a depósitos conhecidos. Estas curvas são interceptadas por percentis e têm a mesma média e desvio padrão dos dados observados.

Foram plotados os valores de tonelagem e teores (vide figuras 21, 22, 23 e 24), de chumbo e zinco, para as minas do Perau e Canoas. Em relação a outros depósitos mundiais notou-se, que em termos de tonelagem, os dois depósitos recaem num grupo onde estão aproximadamente $80 \%$ dos depósitos listados no modelo utilizado. Em termos de teor de chumbo os dois depósitos estão acima do $50^{\circ}$ percentil. O depósito do Perau apresenta teor de chumbo correspondente a apenas $30 \%$ dos depósitos listados. Quanto ao teor de zinco verifica-se que os depósitos do Perau e Canoas estão próximos ao $90^{\circ}$ percentil, e a Mina de Canoas apresenta teor que a coloca acima do $90^{\circ}$ percentil. Em termos de teores de prata, os dois depósitos estão entre o $10^{\circ}$ e $50^{\circ}$ percentis, o que demonstra a importância econômica deste bem, em relação aos outros bens analisados, na viabilização da exploração destas jazidas.

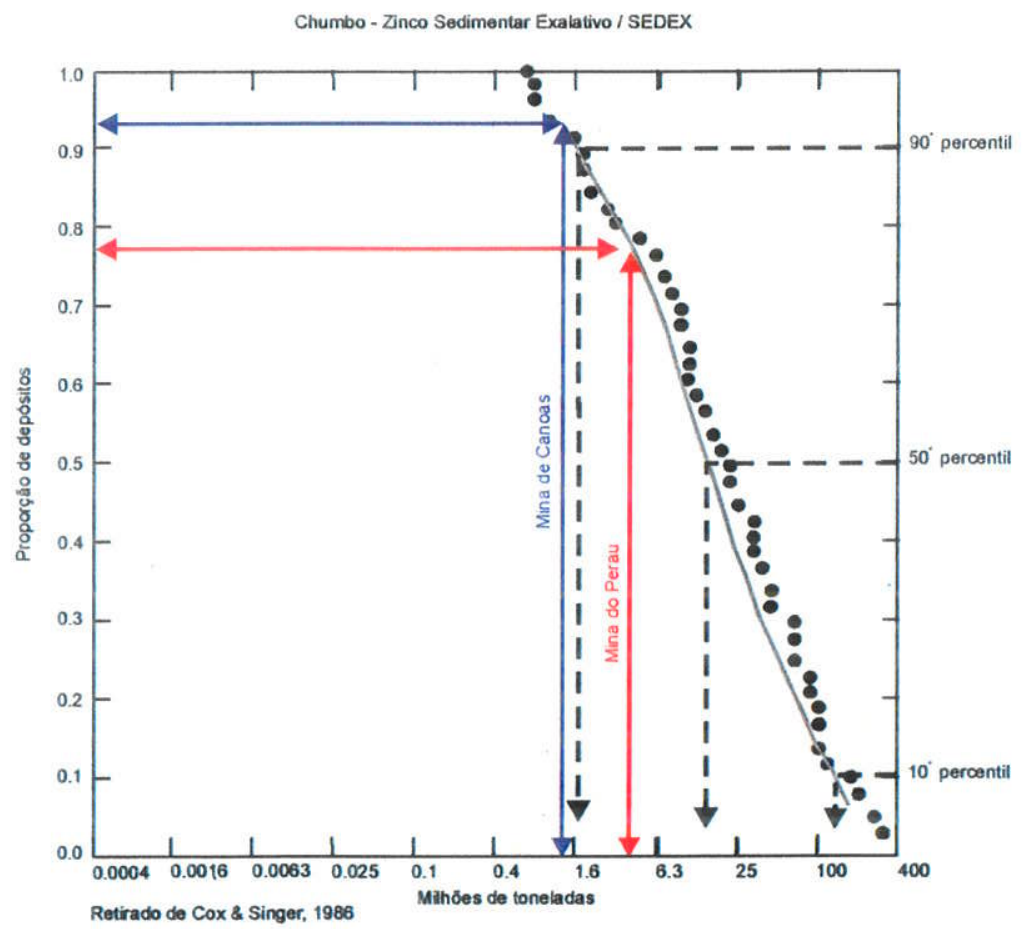

Figura 21: Tonelagens dos depósitos sedimentar-exalativos. 


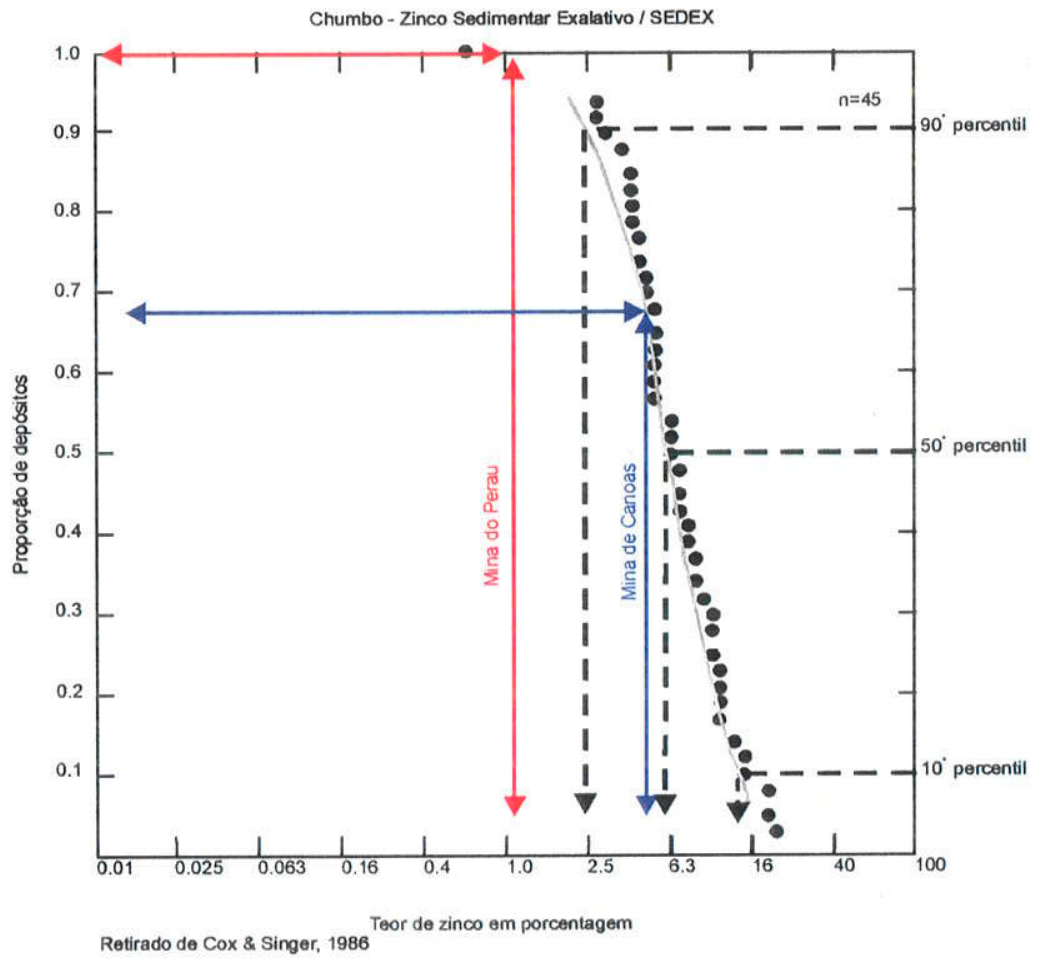

Figura 22: Teores de zinco em depósitos de $\mathrm{Zn}$ - Pb sedimentar-exalativos.

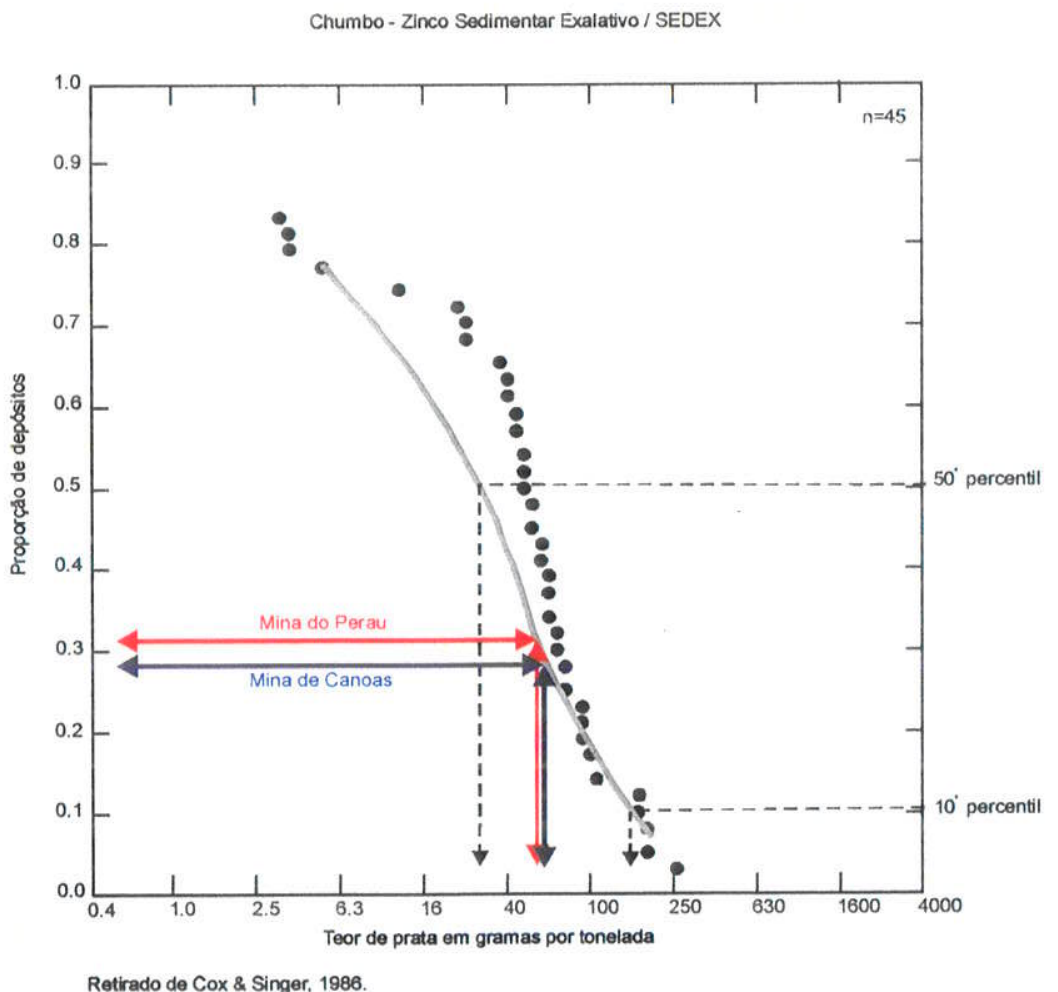

Figura 23: Teores de prata em depósitos sedimentar-exalativos. 
Chumbo - Zinco Sedimentar Exalativo / SEDEX

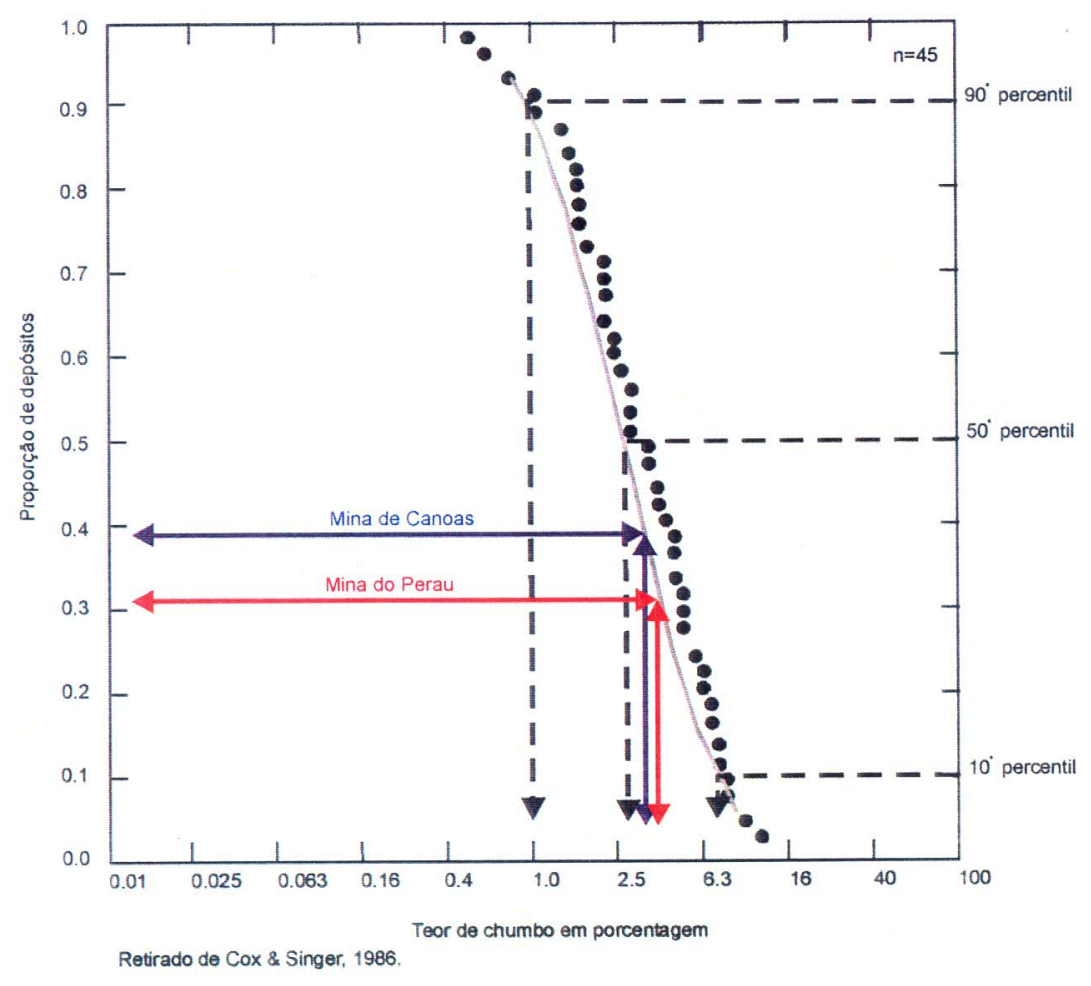

Figura 24: Teores de chumbo em depósitos sedimentar exalativos

\subsection{Dados de fraturamento}

Nas figuras 25, 26, 27 e 28 são apresentados os seguintes dados: a roseta mostrando as principais direções de zonas de fraturamento, o mapa de feições lineares de drenagem, o mapa de isofreqüência de zonas de fraturamento e o mapa de interpretação com as áreas de eixos de maior freqüência de zonas de fraturamento.

Segundo os parâmetros prospectivos do tipo Panelas foi feita uma tentativa de análise dos dados de fraturamento apenas nas áreas de litologias carbonáticas, já que as mineralizações filonares ocorrem encaixadas em fraturas em dolomitos e calcários. Notou-se que a escala regional de trabalho não permite este tipo de análise, ou seja, separar as fraturas em um determinado litotipo. Da mesma maneira, foram analisados os contatos granitos/carbonatos. Conclui-se que este tipo de análise requer uma interpretação das zonas de fraturamento no Vale do Ribeira em escalas maiores que 1:50.000. Optou-se por uma aplicação simplificada dos dados de fraturamento, sem uma correlação geológica direta entre as mineralizações e as diferentes direções de zonas de fraturamento. Isto 
foi feito devido a incompatibilidade entre a escala dos dados interpretados e a escala de trabalho necessária para a correlação com as mineralizações, a qual seria de maior detalhe $(1: 25.000)$.

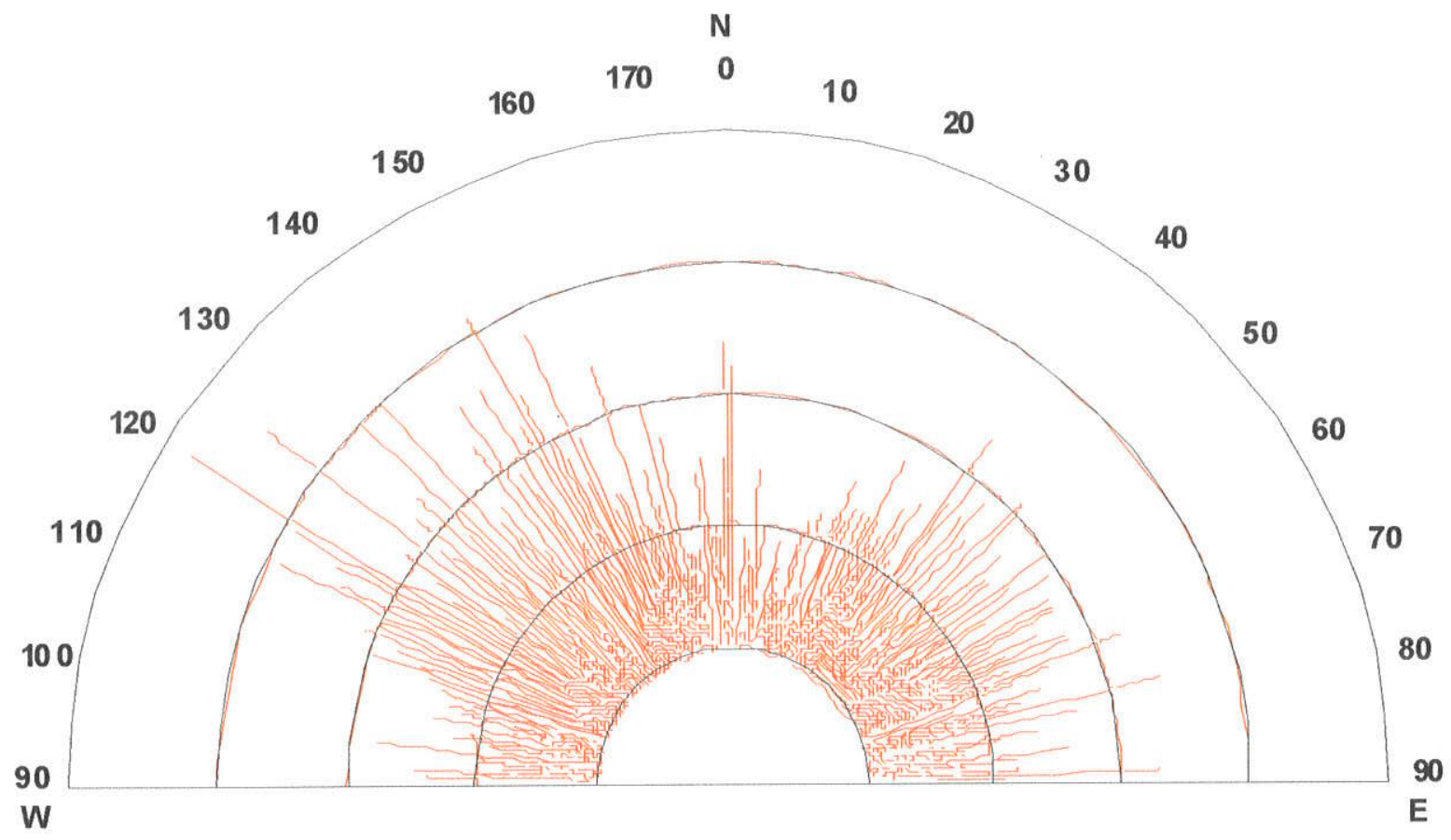

Figura 25: Roseta das feições lineares de drenagem

O principal produto obtido a partir da análise regional de fraturamentos é o mapa de áreas de eixos de fraturamento. Teoricamente este produto indica áreas de fraqueza crustal, reativadas ao longo da história geológica. Estas áreas seriam propícias à percolação de fluidos mineralizantes e à deposição dos sulfetos assim como na instalação de sistemas hidrotermais (como zonas de stockwork). Contudo notou-se que estas áreas têm correspondência apenas parcial com as ocorrências minerais disponíveis. Isto ocorre devido às limitações do método (discutidas na apresentação da metodologia) e também devido às particularidades das mineralizações como dimensão dos corpos, direções preferenciais, entre possíveis outras. Dessa forma utilizam-se os dados de fraturamento com pesos relativamente menores que os atribuídos a outros parâmetros prospectivos. 


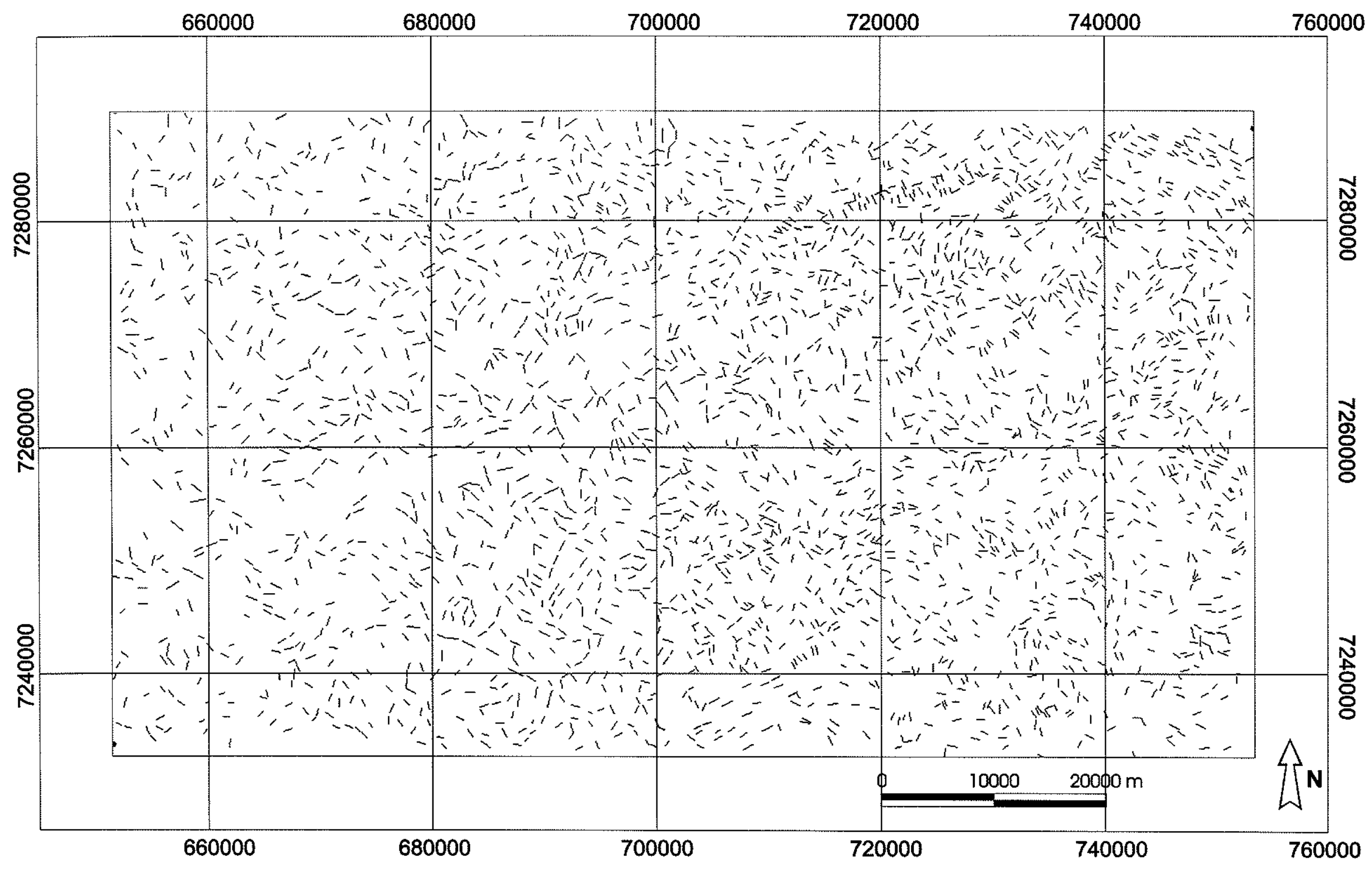

Figura 26: Feições lineares interpretadas da rede de drenagem. 

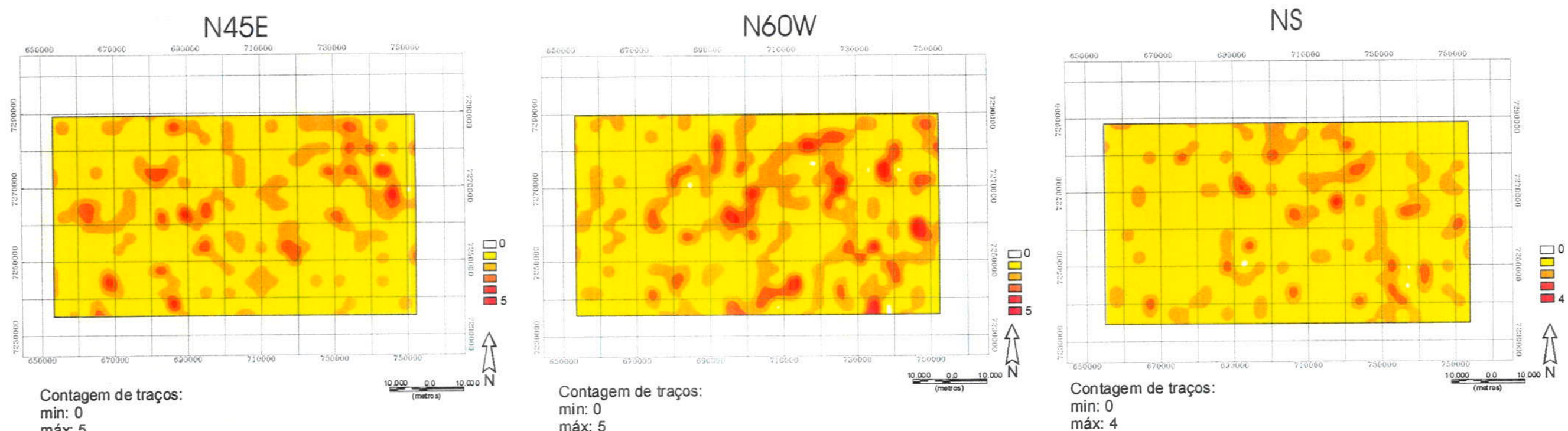

$$
\text { máx } 5 \text { N70E }
$$

\section{N70E}

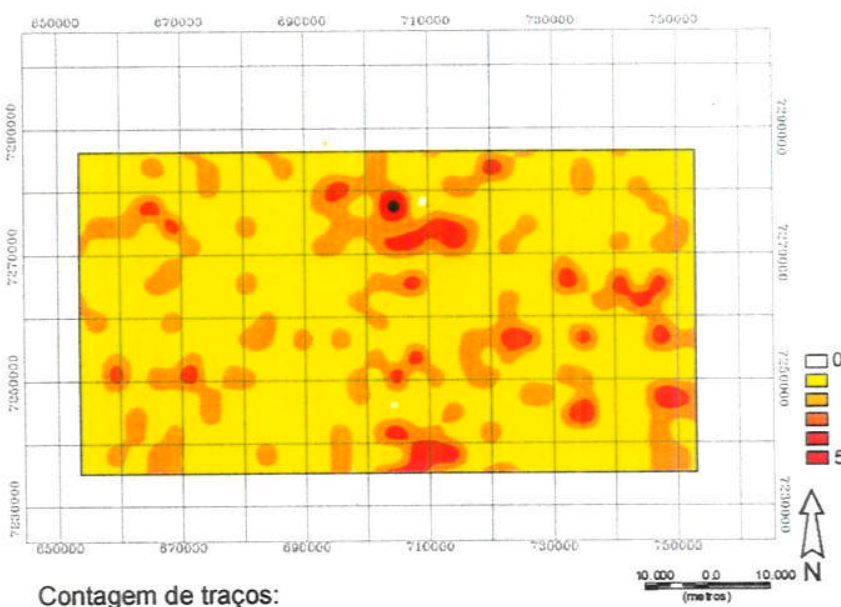

Contagem de traços:

min: 0

Contagem de traços:
min: 0

N30W
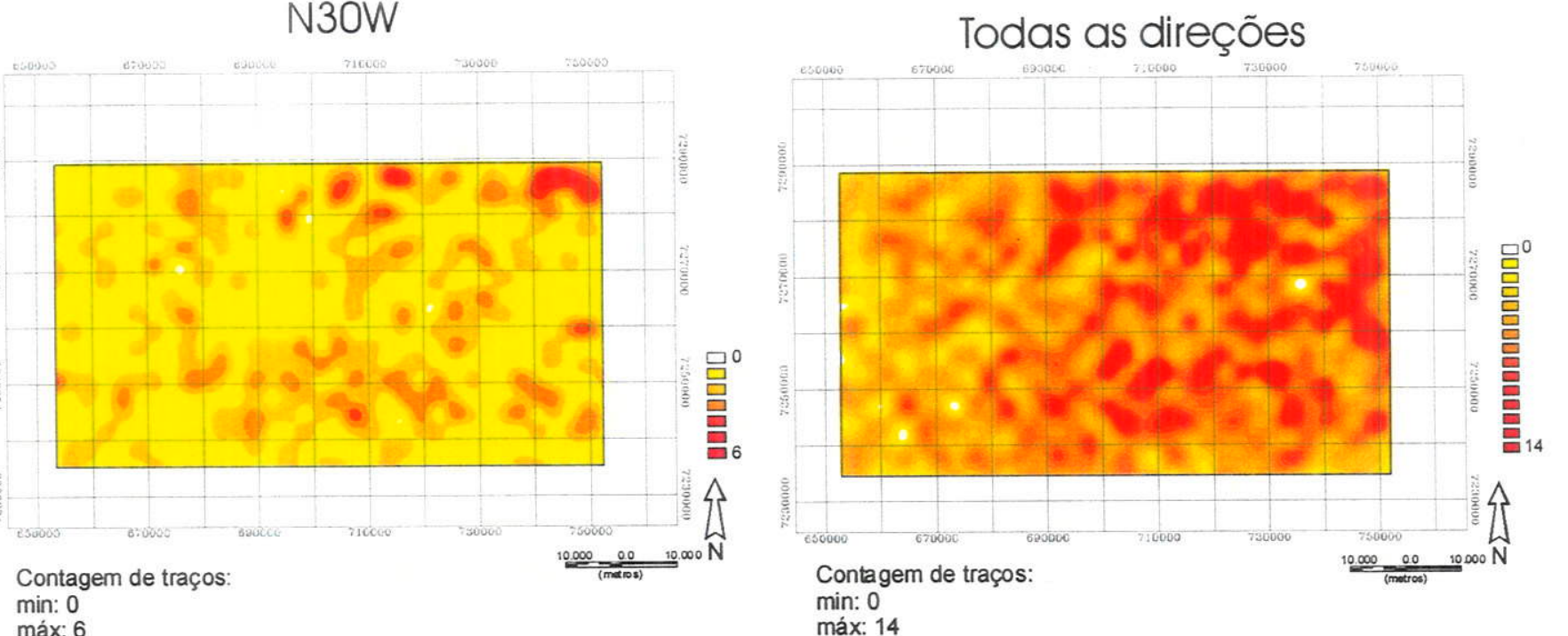
T2782

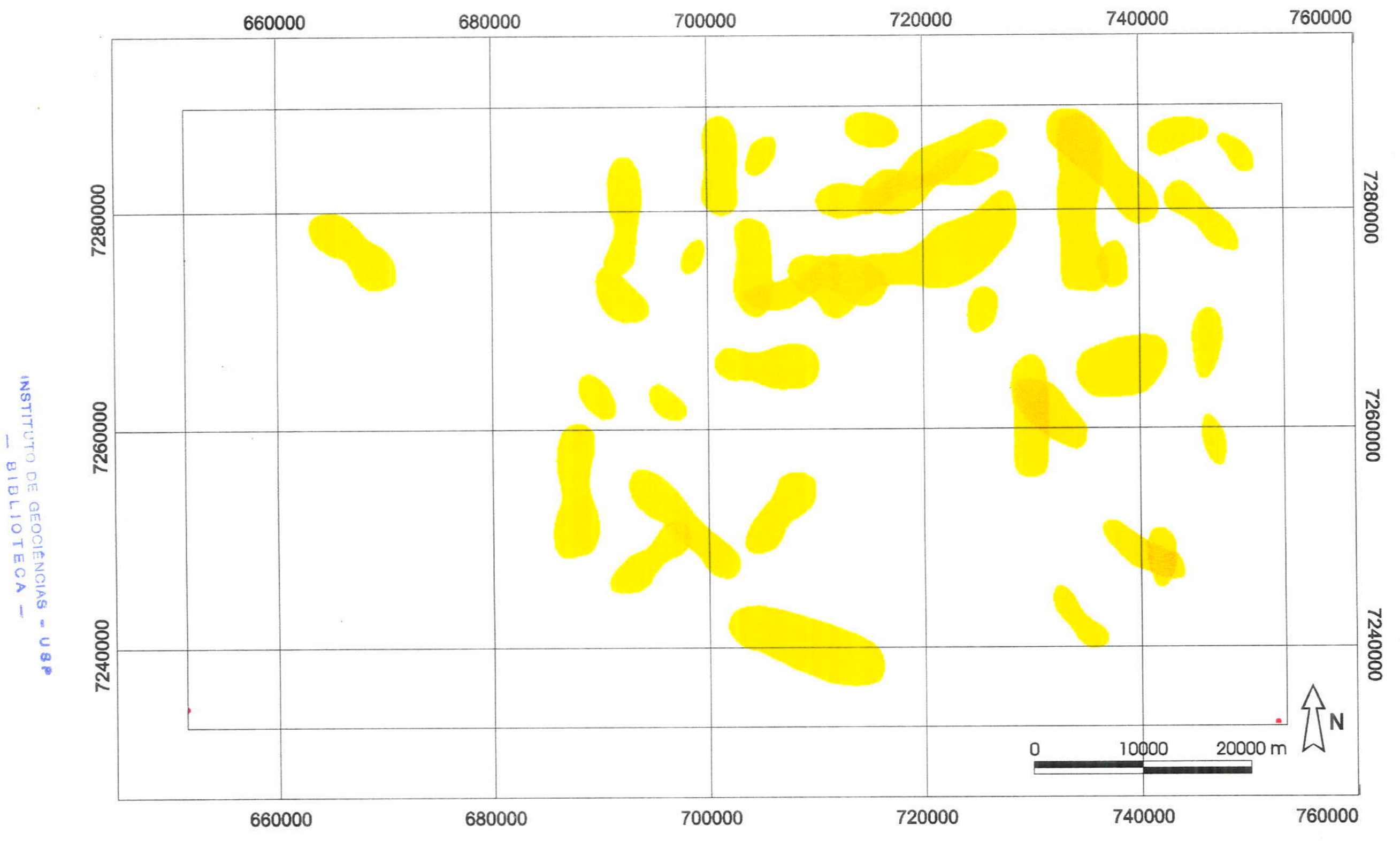

Figura 28: Interpretação das áreas com maior freqüência de zonas de fraturamento. 


\section{INTEGRAÇÃO DE DADOS E SELEÇÃO DE ÁREAS FAVORÁVEIS}

\subsection{Definição dos pesos aos parâmetros prospectivos}

Para definir a ordenação dos fatores e a escala de favorabilidade para cada fator, foram atribuídos pesos aos parâmetros prospectivos. A definição destes pesos foi feita a partir de dados bibliográficos e de discussões com geólogos que têm experiência nessa área de estudo e no tipo de mineralização abordada. Deste modo, estes profissionais foram encarados como peritos, cujas opiniões foram utilizadas para melhor definir os pesos.

Os pesos finais apresentados nas tabelas a seguir foram definidos, por este autor, com base nas opiniões dos diversos peritos, consideradas tanto do ponto de vista do peso, como número absoluto, quanto das discussões a respeito da justificativa de cada peso.

A análise utilizando ponderadores tem um caráter subjetivo já que não é possivel definir pesos para todas as evidências de um modelo, justificando-as a partir de elementos fatuais.

As tabelas 22, 23, 24 e 25 contém os pesos do modelo Panelas. As tabelas $26,27,28$ e 29 contém os pesos do modelo Perau. 
Tabela 22 :Parâmetros prospectivos - fator litológico - Panelas

\begin{tabular}{|c|c|c|c|c|c|c|c|}
\hline Descrição dos parâmetros prospectivos & Perito 1 & Perito 2 & Perito 3 & Perito 4 & Perito 5 & Perito 6 & Inal \\
\hline Peso do fator litológico & 10 & 10 & 10 & 10 & 10 & 9 & 10 \\
\hline Descrição & & & & & & & \\
\hline Mármores dolomíticos e calciticos - & 10 & 10 & 10 & 10 & 10 & 10 & 10 \\
\hline $2 \mathrm{~m} / 4 \mathrm{~m}$ & & & & & & & \\
\hline Rochas cálcio-silicáticas, carbonato & 4 & 4 & 4 & 4 & 6 & 6 & 4 \\
\hline xistos com intercalações de mármores & & & & & & & \\
\hline$-\mathrm{CS}$ & & & & & & & \\
\hline Mármores dolomíticos - M & 6 & 8 & 8 & 8 & 8 & 6 & 6 \\
\hline Alternância de mármores dolomiticos e & 2 & 4 & 4 & 4 & 6 & 6 & 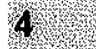 \\
\hline mica xistos - MX & & & & & & & \\
\hline Contato entre mármores dolomiticos e & 8 & 6 & 6 & 6 & 5 & 6 & 6 \\
\hline calcíticos com xistos e filitos $-2 \mathrm{~m}$ - & & & & & & & \\
\hline $4 \mathrm{~m} / \mathrm{X}-\mathrm{F}$ & & & & & & & \\
\hline
\end{tabular}

Tabela 23: Parâmetros prospectivos - fator estratigráfico - Panelas

\begin{tabular}{|c|c|c|c|c|c|c|c|}
\hline $\begin{array}{l}\text { Fator estratigráfico - peso do fator: } \\
\text { Descrição }\end{array}$ & 8 & 6 & 5 & 8 & 9 & 10 & 8 \\
\hline Subgrupo Lajeado - vl & 10 & 10 & 10 & 8 & 10 & 10 & 証 \\
\hline Grupo Itaiacoca - i & 6 & 8 & 8 & 6 & 4 & 6 & 8 \\
\hline Formação Água Clara - ac & 2 & 4 & 4 & 3 & 6 & 6 & 6 \\
\hline
\end{tabular}

Tabela 24: Parâmetros prospectivos - fator geoquímico - Panelas

\begin{tabular}{|c|c|c|c|c|c|c|c|}
\hline $\begin{array}{l}\text { Fator geoquímico - peso do fator: } \\
\text { Descrição }\end{array}$ & 6 & 5 & 10 & 6 & 7 & 6 & 7 \\
\hline $\mathrm{Pb}$ & 8 & 8 & 8 & 6 & 8 & 4 & IO \\
\hline $\mathrm{Zn}$ & 6 & 6 & 6 & 4 & 6 & 4 & $\gamma^{2}$ \\
\hline $\mathrm{Cu}$ & 6 & 6 & 6 & 2 & 4 & 4 & V \\
\hline
\end{tabular}

Tabela 25: Parâmetros prospectivos - fator estrutural - Panelas

\begin{tabular}{llllllll}
\hline $\begin{array}{l}\text { Fator estrutural - peso do fator: } \\
\text { Descrição }\end{array}$ & 5 & 5 & 5 & 4 & 8 & 6 & 5 \\
\hline Eixos de dobras & 8 & 10 & 10 & 4 & 8 & 10 & 5 \\
Eixos de máxima frequeencia de & 6 & 5 & 5 & 8 & 8 & 0 & 5 \\
fraturamento & & & & & & & 5 \\
Falhas & 4 & 5 & 5 & 6 & 10 & 0 & 5 \\
Lineamentos magnéticos & 2 & 2 & 2 & 5 & 6 & 0 & 2 \\
\hline
\end{tabular}


Tabela 26: Parâmetros prospectivos - fator litológico - Perau

\begin{tabular}{|c|c|c|c|c|c|c|c|}
\hline $\begin{array}{l}\text { Descrição dos parâmetros } \\
\text { prospectivos }\end{array}$ & Perito 1 & Perito 2 & Perito 3 & Perito 4 & Perito 5 & Perito 6 & Final \\
\hline $\begin{array}{l}\text { Fator litológico - peso do } \\
\text { submodelo }\end{array}$ & 6 & 6 & 10 & 8 & 8 & 7 & 8 \\
\hline Descrição & & & & & & & \\
\hline $\begin{array}{l}\text { carbonato xistos com } \\
\text { intercalaçőes de mármores-CS }\end{array}$ & 10 & 10 & 10 & 10 & 10 & 5 & 10 \\
\hline $\begin{array}{l}\text { alternância de mármores } \\
\text { dolomíticos e mica xistos - MX }\end{array}$ & 6 & 5 & 10 & 8 & 8 & 0 & 6 \\
\hline $\begin{array}{l}\text { xistos com intercalações de } \\
\text { quartzitos - AS/AF, } \\
\text { metarritmitos e metargilitos - X }\end{array}$ & 4 & 3 & 0 & 5 & 6 & 0 & 8 \\
\hline $\begin{array}{l}\text { metavulcânicas básicas e } \\
\text { ácidas - B }\end{array}$ & 8 & 5 & 5 & 0 & 4 & 5 & 9 \\
\hline
\end{tabular}

Tabela 27: Parâmetros prospectivos - fator estratigráfico - Perau

\begin{tabular}{|c|c|c|c|c|c|c|c|}
\hline $\begin{array}{l}\text { Fator estratigráfico - peso do } \\
\text { fator: } \\
\text { Descrição }\end{array}$ & 10 & 10 & 5 & 5 & 10 & 10 & 10 \\
\hline Formação Perau - vp & 8 & 10 & 8 & 7 & 10 & 5 & 8 \\
\hline Subgrupo Ribeira - $v$ & 5 & 5 & 5 & 4 & 6 & 5 & 6 \\
\hline $\begin{array}{l}\text { Corredor externo no contato } \\
\text { quartzitos/pelitos da Formação }\end{array}$ & 10 & 8 & 10 & 7 & 8 & 10 & 10 \\
\hline Perau & & & & & & & \\
\hline
\end{tabular}

Tabela 28: Parâmetros prospectivos - fator geoquímico - Perau

\begin{tabular}{lccccccc}
\hline $\begin{array}{l}\text { Fator geoquímico-peso do } \\
\text { fator: }\end{array}$ & 8 & 8 & 10 & 8 & 6 & 8 & 7 \\
Descrição & & & & & & & 7 \\
\hline $\mathrm{Pb}$ & 7 & 7 & 7 & 5 & 6 & 6 & 10 \\
$\mathrm{Zn}$ & 6 & 6 & 3 & 3 & 4 & 5 & 5 \\
$\mathrm{Cu}$ & 5 & 5 & 3 & 3 & 4 & 4 & 5
\end{tabular}

Tabela 29: Parâmetros prospectivos - fator estrutural - Perau

\begin{tabular}{|c|c|c|c|c|c|c|c|c|}
\hline $\begin{array}{l}\text { Fator estrutural - peso do fato } \\
\text { Descrição }\end{array}$ & & 4 & 3 & 4 & 5 & 2 & & 3 \\
\hline Lineamentos - Falhas & 10 & 7 & 5 & 8 & 8 & 1 & & 10 \\
\hline Lineamentos Magnéticos & 4 & 3 & 3 & 5 & 4 & 2 & & 2 \\
\hline $\begin{array}{l}\text { Zonas de máxima freqüência } \\
\text { de fraturamento }\end{array}$ & 5 & 5 & 0 & 3 & 6 & 0 & 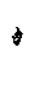 & 4 \\
\hline
\end{tabular}




\subsection{Construção dos fatores}

$\mathrm{Na}$ construção dos fatores foram considerados os pesos, atribuídos aos parâmetros prospectivos, numa escala de 0 a 10 , os quais foram reclassificados numa escala contínua de favorabilidade com classes de 0 a 255 , devido à exigência do programa Idrisi 2.0 for Windows.

A reclassificação dessas escalas utilizou o método lógico fuzzy. No caso da reclassificação dos fatores, a escala contínua varia de 255 (favorável) a 0 (não favorável).

O módulo fuzzy do IDRISI tem três funções de pertinência implementadas (sigmoidal, linear e em forma de $\mathrm{J}$ ), além da possibilidade do usuário definir uma função própria. A função de pertinência ainda pode ser definida como crescente, decrescente ou simétrica. Nos dois primeiros casos, utilizam-se dois pontos de controle, no último caso são necessários quatro pontos de controle.

$\mathrm{Na}$ construção dos fatores foram utilizadas funções lineares e funções sigmoidais. A função sigmoidal foi utilizada para se definir a variação de um peso em função de distância, como no caso dos corredores ao redor de estruturas lineares. Neste caso os valores no centro dos corredores (falhas, contatos, eixos de dobras, lineamentos magnéticos) permaneceu proporcional ao valor original pré-definido e os valores próximos as bordas destes corredores aumentavam ou diminuiam em função do tipo de função adotada (decrescente ou crescente).

A função linear foi utilizada, nos casos em que apenas havia necessidade de se reescalonar os valores de uma escala $(0-10$, pesos dos parâmetros prospectivos) para outra $(0-255$, escala exigida pelo programa Idrisi para a análise), especialmente para a reclassificação de niveis de informação mantendose a proporcionalidade dos valores originais.

Nota-se que a lógica fuzzy no caso das funções lineares foi empregada apenas para a reclassificação de valores e não para a definição de áreas de incerteza como foi feito no caso das funções sigmoidais aplicadas aos elementos lineares (falhas, eixos, etc).

Os valores adotados no pontos de controle das funções sigmoidais também foram discutidos com os peritos e os valores finais foram ponderados por este autor. No caso das funções lineares foram observados os valores máximos e 
mínimos de cada nivel de informação. $\mathrm{Na}$ construção dos fatores, as diversas classes foram reclassificadas, como descrito nas tabelas a seguir $(30,31,32,33$, 34 e 35 ) segundo os modelos prospectivos adotados:

Tabela 30: Reclassificação do fator litológico - Panelas

\begin{tabular}{lll}
\hline Classes & Função de pertinência & Pontos de controle: $a-b$ \\
\hline Litologias favoráveis & linear crescente & $0-10$ \\
Distância dos contatos & sigmoìdal decrescente & $100-300$ \\
carbonatos/xistos e filitos & & \\
\hline
\end{tabular}

Tabela 31: Reclassificação do fator litológico - Perau

\begin{tabular}{lll}
\hline Classes & Função de pertinência & Pontos de controle $a-b$ \\
\hline Litologias favoráveis & linear crescente & $0-10$ \\
\hline
\end{tabular}

Tabela 32: Fator estratigráfico - Panelas/Perau

\begin{tabular}{lll}
\hline Classes & Função de pertinência & Pontos de controle: $a-b$ \\
\hline Unidades favoráveis & linear crescente & $0-10$ \\
\hline
\end{tabular}

Tabela 33: Reclassificação do fator geoquímico - Panelas/Perau

\begin{tabular}{llc}
\hline Classes & Função de pertinência & Pontos de controle: $a-b$ \\
\hline $\mathrm{Pb}$ & linear crescente & $1-42,37$ \\
$\mathrm{Zn}$ & linear crescente & $1-15$ \\
$\mathrm{Cu}$ & linear crescente & $1-3,33$
\end{tabular}

Tabela 34: Reclassificação do fator estrutural - Panelas

\begin{tabular}{lll}
\hline Classes & Função de pertinência & Pontos de controle: $a-b$ \\
\hline Distância dos eixos de dobras & sigmoidal decrescente & $500-750$ \\
Distância das falhas & sigmoidal decrescente & $150-250$ \\
Distância dos lineamentos & sigmoidal decrescente & $150-250$ \\
magnéticos & & $0-10$ \\
Eixos de fraturamento & linear crescente & 0 \\
\hline
\end{tabular}

Tabela 35: Reclassificação do fator estrutural - Perau

\begin{tabular}{lll}
\hline Classes & Funçåo de pertinéncia & Pontos de controle: $a-b$ \\
\hline $\begin{array}{l}\text { Distância das falhas } \\
\text { Distância dos lineamentos sigmoidal decrescente }\end{array}$ & $500-1000$ \\
magnéticos & & $500-1000$ \\
Eixos de fraturamento & linear crescente & $0-10$ \\
\hline
\end{tabular}




\subsection{Análise Booleana}

$\mathrm{Na}$ análise booleana foram utilizados os fatores (litológico, estratigráfico, geoquímico e estrutural) como niveis de evidência. As classes dos fatores foram reclassificadas para valores binários, ou seja, presença de evidência com valor 1 e ausência de evidência com valor 0 .

A análise booleana restringe-se apenas aos fatores/classes binários, mapas/fatores com várias classes ponderadas são tratados a partir de uma análise de índices ponderados, apresentada nos próximos tópicos. Uma caracterísitica da lógica booleana é a não utilização de valores intermediários.

$\mathrm{Na}$ construção dos fatores, a partir dos elementos que compõem as classes, foi utilizada a operação lógica booleana OR (união) devido à baixa correlação espacial das classes de cada fator, contudo essas classes têm uma corrrelação alta com o modelo prospectivo adotado em cada caso (Panelas e Perau).

$\mathrm{Na}$ definição do produto final, o mapa de favorabilidade booleano, foi utilizada a operação lógica booleana AND (intersecção) devido à necessidade de se encontrar áreas onde havia sobreposição de todos os fatores, ou melhor, onde todas as condições eram satisfeitas.

As tabelas 36 e 37 apresentam os fatores e classes utilizados na análise booleana dos modelos Panelas e Perau.

Tabela 36: Fatores e classes - análise booleana Panelas

\begin{tabular}{ll}
\hline Fator & Classe \\
\hline Litológico & litologia favoráveis \\
& corredor $300 \mathrm{~m}$ - contatos carbonáticas/terrigenas \\
Estratigráfico & unidades favoráveis \\
beoquímico & bacias anômalas $-\mathrm{Pb}$ \\
& bacias anômalas $-\mathrm{Zn}$ \\
& bacias anômalas $-\mathrm{Cu}$ \\
Estrutural & corredor $1500 \mathrm{~m}$ - eixos de dobras \\
& corredor $500 \mathrm{~m}$ - falhas \\
& corredor $1500 \mathrm{~m}$ - lineamentos magnéticos \\
& eixos de fraturamento
\end{tabular}


Tabela 37: Fatores e classes - análise booleana Perau

\begin{tabular}{ll}
\hline Fator & Classe \\
\hline Litológico & litologia favoráveis \\
Estratigráfico & unidades favoráveis \\
Geoquímico & bacias anômalas $-\mathrm{Pb}$ \\
& bacias anómalas $-\mathrm{Zn}$ \\
& bacias anômalas $-\mathrm{Cu}$ \\
Estrutural & corredor 1000 $\mathrm{m}$ - falhas \\
& corredor 1000 $\mathrm{m}$ - lineamentos magnéticos \\
& eixos de fraturamento
\end{tabular}

O resultado da análise tipo Perau e tipo Panelas é apresentado nas figuras 29 e 30 .

A partir do resultado obtido na análise booleana para os modelos Perau e Panelas foi feita uma tabulação cruzada entre os mapas de favorabilidade e as respectivas ocorrências minerais do tipo Perau e Panelas.

A tabulação cruzada é uma operação na qual as classes de umà imagem (análise CLP) são comparadas com as classes de uma outra imagem (ocorrências minerais). Como resultado, apresenta-se uma tabela de correspondência do número de células em cada combinação de classes das duas imagens (tabelas 38 e 39 ).

Tabela 38: Tabulação cruzada - análise booleana Panelas

\begin{tabular}{l|ll}
\hline $\begin{array}{l}\text { Classes da } \\
\text { imagem }\end{array}$ & 0 (não favorável) & 1 (favorável) \\
$\begin{array}{l}\text { CLP } \\
\text { Células com } \\
\text { ocorrências }\end{array}$ & 52 & 30 \\
\hline
\end{tabular}

Tabela 39: Tabulação cruzada - análise booleana Perau

\begin{tabular}{l|ll}
\hline $\begin{array}{l}\text { Classes da } \\
\text { imagem }\end{array}$ & 0 (não favorável) & 1 (favorável) \\
$\begin{array}{l}\text { CLP } \\
\text { Células com } \\
\text { ocorrências }\end{array}$ & 7 & 0 \\
\hline
\end{tabular}




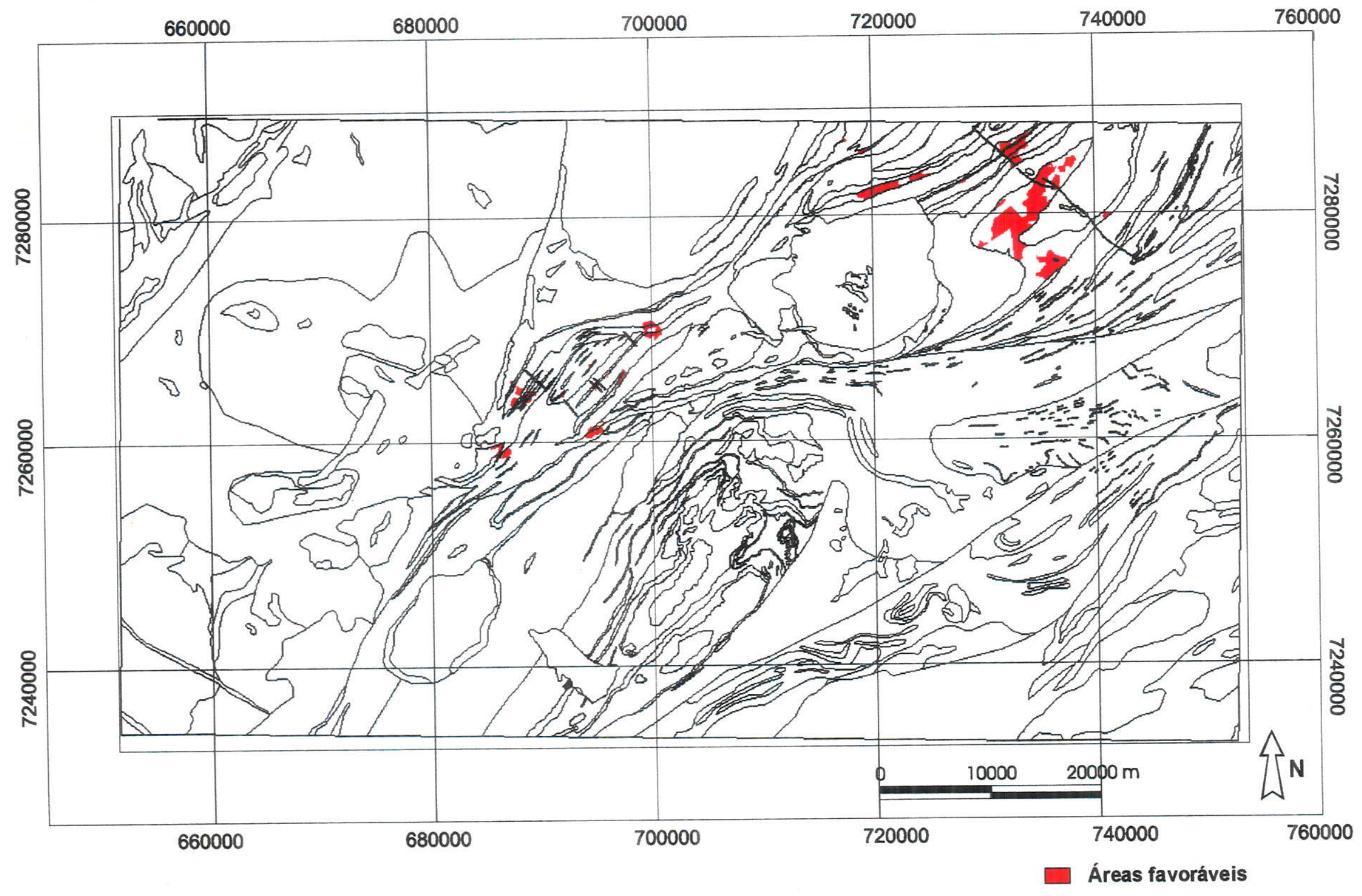

Figura 29: Mapa de Favorabilidade - Análise booleana Panelas 


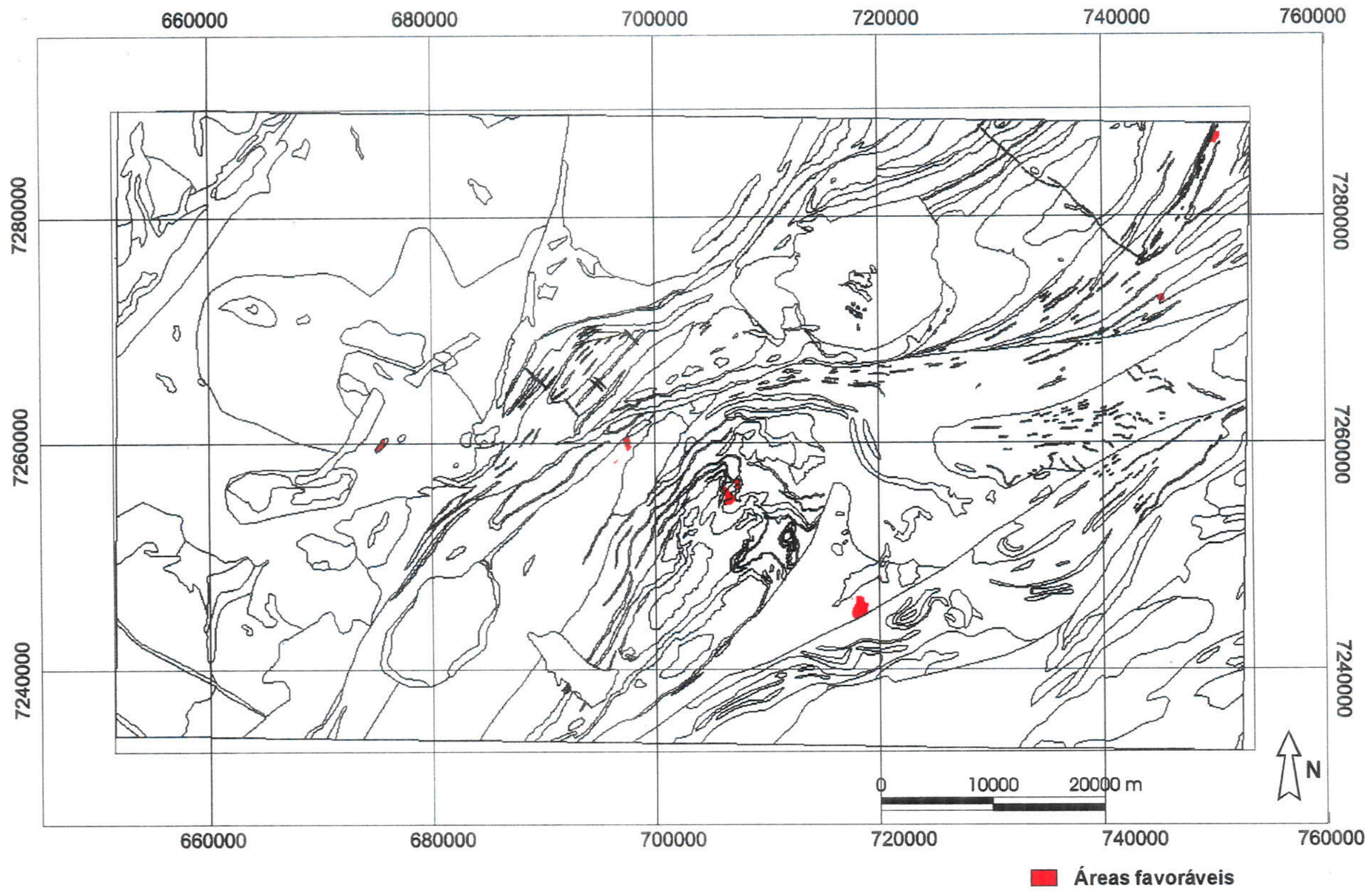

Figura 30: Mapa de favorabilidade - Análise booleana Perau. 


\subsection{Análise por combinação linear ponderada}

Este tipo de análise caracteriza-se por utilizar a variabilidade de todas as classes de fatores, que são expressos na forma de dados contínuos, tornando-se possível a utilização de classes de pouca favorabilidade até valores extremos de importância. Contudo, os fatores não são ponderados de forma absoluta, neste tipo de análise; são analisados segundo a importância relativa de cada fator.

A definição da importância relativa de cada fator é feita por comparação aos pares entre os fatores. Esta importância relativa pode ser chamada de peso de compensação. A combinação aos pares é um processo de análise de hierarquia e é baseada no trabalho de Saaty (1977 apud Eastman, 1997).

No programa Idrisi, o módulo weight possibilita a verificação dos pesos de compensação dados aos fatores. $O$ usuário define um peso a cada par de fatores apresentado segundo sua importância relativa. Os pesos definidos pelo usuário devem considerar os dois fatores envolvidos na análise de determinado par. Estes pesos têm intervalos de valores definidos pelo programa. A consistência dos pesos determinados pelo usuário é calculada a partir dos autovetores da matriz de fatores, como a apresentada nas tabelas 40 e 41 .

Tabela 40: Pesos dos fatores - Panelas

\begin{tabular}{l|llll}
\hline & litologia & Estratigrafia & geoquimica & estrutural \\
\hline Litologia & 1 & $\mathrm{X}$ & $\mathrm{X}$ & $\mathrm{X}$ \\
Estratigrafia & $1 / 3$ & 1 & $\mathrm{X}$ & $\mathrm{X}$ \\
Geoquímica & $1 / 5$ & $1 / 3$ & 1 & $\mathrm{X}$ \\
Estrutural & $1 / 9$ & $1 / 9$ & $1 / 7$ & 1 \\
\hline
\end{tabular}

Tabela 41: Pesos dos fatores - Perau

\begin{tabular}{l|llll}
\hline & estratigrafia & litologia & geoquímica & estrutural \\
\hline estratigrafia & 1 & $\mathrm{X}$ & $\mathrm{X}$ & $\mathrm{X}$ \\
litologia & $1 / 3$ & 1 & $\mathrm{X}$ & $\mathrm{X}$ \\
geoquimica & $1 / 5$ & $1 / 3$ & 1 & $\mathrm{X}$ \\
estrutural & $1 / 9$ & $1 / 7$ & $1 / 7$ & 1 \\
\hline
\end{tabular}


O programa apresenta a seguinte ordenação de pesos quando se analisam quatro fatores (tabela 42):

Tabela 42: Escala de pesos - Idrisi

\begin{tabular}{|l|l|l|l|l|l|l|l|l|}
\hline $1 / 9$ & $1 / 7$ & $1 / 5$ & $1 / 3$ & 1 & 3 & 5 & 7 & 9 \\
\hline Extremamente fortemente moderadamente & igualmente & moderadadamente fortemente extremamente \\
\hline
\end{tabular}

Exemplificando, quando é feita a comparação da estratigrafia com a litologia, o valor $1 / 3$ significa que a estratigrafia tem uma importância relativa moderadamente menor do que a litologia e assim sucessivamente. Se fosse colocado um valor igual a 5 , isto significaria que a estratigrafia é moderadamente a fortemente mais importante do que a litologia. De modo geral, os fatores, para a análise de favorabilidade tipo Panelas, podem ser ordenados, em termos absolutos, na seguinte ordem: litologia, estratigrafia, geoquímica e estrutural. Os pesos absolutos (pesos definidos para os fatores) neste tipo de análise não são utilizados, mas sim os pesos relativos definidos na tabela acima.

Tabela 43: Pesos de compensação obtidos a partir do módulo WEIGHT para a análise Panelas

\begin{tabular}{|l|l|}
\hline Fator & Peso \\
\hline Litológico & 0,55 \\
\hline Estratigráfico & 0,28 \\
\hline Geoquímico & 0,14 \\
\hline Estrutural & 0,03 \\
\hline
\end{tabular}

Tabela 44: Pesos de compensação obtidos a partir do módulo WEIGHT para a análise Perau

\begin{tabular}{|l|l|}
\hline Fator & Peso \\
\hline Litológico & 0,26 \\
\hline Estratigráfico & 0,56 \\
\hline Geoquímico & 0,14 \\
\hline Estrutural & 0,04 \\
\hline
\end{tabular}

A partir dos pesos de compensação (tabelas 43 e 44) e dos pesos atribuídos pelos peritos para cada classe apresenta-se um quadro resumo (tabelas 45 e 46). Este quadro apresenta os pesos utilizados nas análises. $O$ resultado apresentado na soma ponderada corresponde ao maior valor possivel em um pixel derivado da sobreposição de classes de valor máximo para cada 
fator. Por exemplo, para saber o valor de um pixel, na análise por combinação linear Panelas, cujo fator litológico fosse o mármore $(2 \mathrm{~m} / 4 \mathrm{~m})$, o fator estratigráfico o Subgrupo Lajeado, o fator geoquímico $\circ \mathrm{Pb}$ e o fator estrutural um eixo de dobra, executa-se a seguinte operação algébrica:

$$
(255 \times 0,55)+(255 \times 0,28)+(255 \times 0,03)+(255 \times 0,14)=255
$$

Nota-se que o quadro resumo é simplificado, pois não foram observados os casos onde havia sobreposição de informações em um mesmo fator. Por exemplo, no caso do fator geoquímico, onde havia casos de uma mesma bacia anômala para chumbo, zinco e cobre. Primeiramente gerou-se uma imagem para as anomalias de chumbo, outra para zinco e uma terceira para cobre. Somadas as três imagens, as áreas anômalas nos três elementos teriam um valor igual a $612(255+178,5+178,5)$, mas esta imagem foi reclassificada para um intervalo de 0-255. Este procedimento foi aplicado para todos os fatores utilizados sempre que havia sobreposição de classes dentro de um mesmo fator.

Tabela 45: Quadro resumo simplificado - análise por combinação linear - Panelas

\begin{tabular}{|c|c|c|c|c|c|c|}
\hline Fator & Classe & $\begin{array}{l}\text { Peso da Classe } \\
(0-255)\end{array}$ & $\begin{array}{l}\text { Peso de } \\
\text { compensação }\end{array}$ & Avaliação & $\begin{array}{l}\text { Soma dos } \\
\text { Pesos }\end{array}$ & $\begin{array}{l}\text { Soma } \\
\text { ponderada }\end{array}$ \\
\hline \multirow{5}{*}{ Litologia } & Mármores $(2 \mathrm{~m} / 4 \mathrm{~m})$ & 255 & & 140,25 & & \\
\hline & Mármores dolomiticosM & 153 & & 84,15 & & \\
\hline & Cálcio-silicáticas (CS) & 102 & 0,55 & 56,10 & & \\
\hline & Micaxistos (MX) & 102 & & 56,10 & & \\
\hline & Contatos mármores/ xistos & 153 & & 84,15 & & \\
\hline \multirow[t]{3}{*}{ Estratigrafia } & Subgrupo Lajeado & 255 & & 71,40 & & \\
\hline & Grupo Itaiacoca & 204 & 0,28 & 57,12 & & \\
\hline & Fm. Água Clara & 153 & & 42,84 & 1 & $255^{*}$ \\
\hline \multirow[t]{4}{*}{ Estrutural } & Eixos de dobras & 255 & 0,03 & 7,65 & & \\
\hline & Falhas & 127,5 & & 3,83 & & \\
\hline & Lineamentos magnéticos & 51 & & 1,53 & & \\
\hline & $\begin{array}{l}\text { Eixos de máxima frequéencia de } \\
\text { fraturamento }\end{array}$ & 127,5 & & 3,83 & & \\
\hline \multirow[t]{3}{*}{ Geoquímica } & $\mathrm{Pb}$ & 255 & & 35,7 & & \\
\hline & $\mathrm{Cu}$ & 178,5 & 0,14 & 24,99 & & \\
\hline & $\mathrm{Zn}$ & 178,5 & & 24,99 & & \\
\hline
\end{tabular}


Tabela 46: Quadro resumo simplificado - análise por combinação linear - Perau

\begin{tabular}{|c|c|c|c|c|c|c|}
\hline Fator & Classe & $\begin{array}{l}\text { Peso da Classe } \\
(0-255)\end{array}$ & $\begin{array}{l}\text { Peso de } \\
\text { compensaçăo }\end{array}$ & Avaliação & $\begin{array}{l}\text { Soma dos } \\
\text { Pesos }\end{array}$ & $\begin{array}{l}\text { Soma } \\
\text { ponderada }\end{array}$ \\
\hline & Carbonato xistos (CS) & 255 & & 66,3 & & \\
\hline & Micaxistos (MX) & 153 & & 39,78 & & \\
\hline \multirow[t]{2}{*}{ Litologia } & Xistos (AS/AF, X) & 76.5 & 0,26 & 19,89 & & \\
\hline & Metavulcånicas (B) & 51 & & 13,26 & & \\
\hline \multirow[t]{3}{*}{ Estratigrafia } & Formaçăo Perau (vp) & 204 & & 114,24 & & \\
\hline & Subgrupo Ribeira (v) & 127,5 & 0,56 & 71,4 & & \\
\hline & $\begin{array}{l}\text { Corredor externo no contato } \\
\text { quartzitos/pelitos da Formação } \\
\text { Perau }\end{array}$ & 255 & & 142,8 & 1 & 255 \\
\hline \multirow[t]{3}{*}{ Estrutural } & Falhas & 255 & & 10,2 & & \\
\hline & Lineamentos magnéticos & 51 & 0,04 & 2,04 & & \\
\hline & $\begin{array}{l}\text { Zonas de máxima frequêencia de } \\
\text { fraturamento. }\end{array}$ & 102 & . & 4,08 & & \\
\hline \multirow[t]{3}{*}{ Geoqu/mica } & $\mathrm{Pb}$ & 255 & & 35,7 & & \\
\hline & $\mathrm{Cu}$ & 127,5 & 0,14 & 17,85 & & \\
\hline & $\mathrm{Zn}$ & 127,5 & & 17,85 & & \\
\hline
\end{tabular}
apresentado em fluxograma (figura 31), o qual é um esquema das atividades e subprodutos gerados durante a análise.

Os mapas de favorabilidade para os modelos Perau e Panelas são apresentados nas figuras 32 e 33. Estes mapas foram obtidos a partir da análise por combinação linear ponderada (CLP) e foram comparados com as ocorrências minerais conhecidas na área. A comparação foi feita a partir de uma tabulação cruzada entre mapas de favorabilidade e as ocorrências minerais.

Dessa maneira, foram obtidos os resultados apresentados nas tabelas $47 \mathrm{e}$ 48 para a análise por combinação linear ponderada, respectivamente, para os modelos Panelas e Perau.

Tabela 47: Tabulação cruzada - Panelas - análise por combinação linear ponderada.

\begin{tabular}{|c|c|c|c|c|c|c|c|c|c|c|}
\hline $\begin{array}{l}\text { Classes da } \\
\text { imagem } \\
\text { CLP } \\
\text { Células com } \\
\text { ocorrências }\end{array}$ & 1 & 2 & 3 & 4 & 5 & 6 & 57 & 8 & 17 & 10 \\
\hline \multicolumn{11}{|c|}{$\begin{array}{l}\text { total de ocorrências: } 82 \\
\text { Tabela 48: Tabulacão }\end{array}$} \\
\hline $\begin{array}{l}\text { classes da } \\
\text { imagem CLP }\end{array}$ & 1 & 2 & 3 & 4 & 5 & 6 & 7 & 8 & 9 & 10 \\
\hline $\begin{array}{l}\text { Células com } \\
\text { ocorrências } \\
\text { total de ocorrêno }\end{array}$ & $\left.\right|_{\text {cias: } 7} ^{0}$ & 0 & 1 & 0 & 0 & 0 & 1 & 3 & 1 & 1 \\
\hline
\end{tabular}




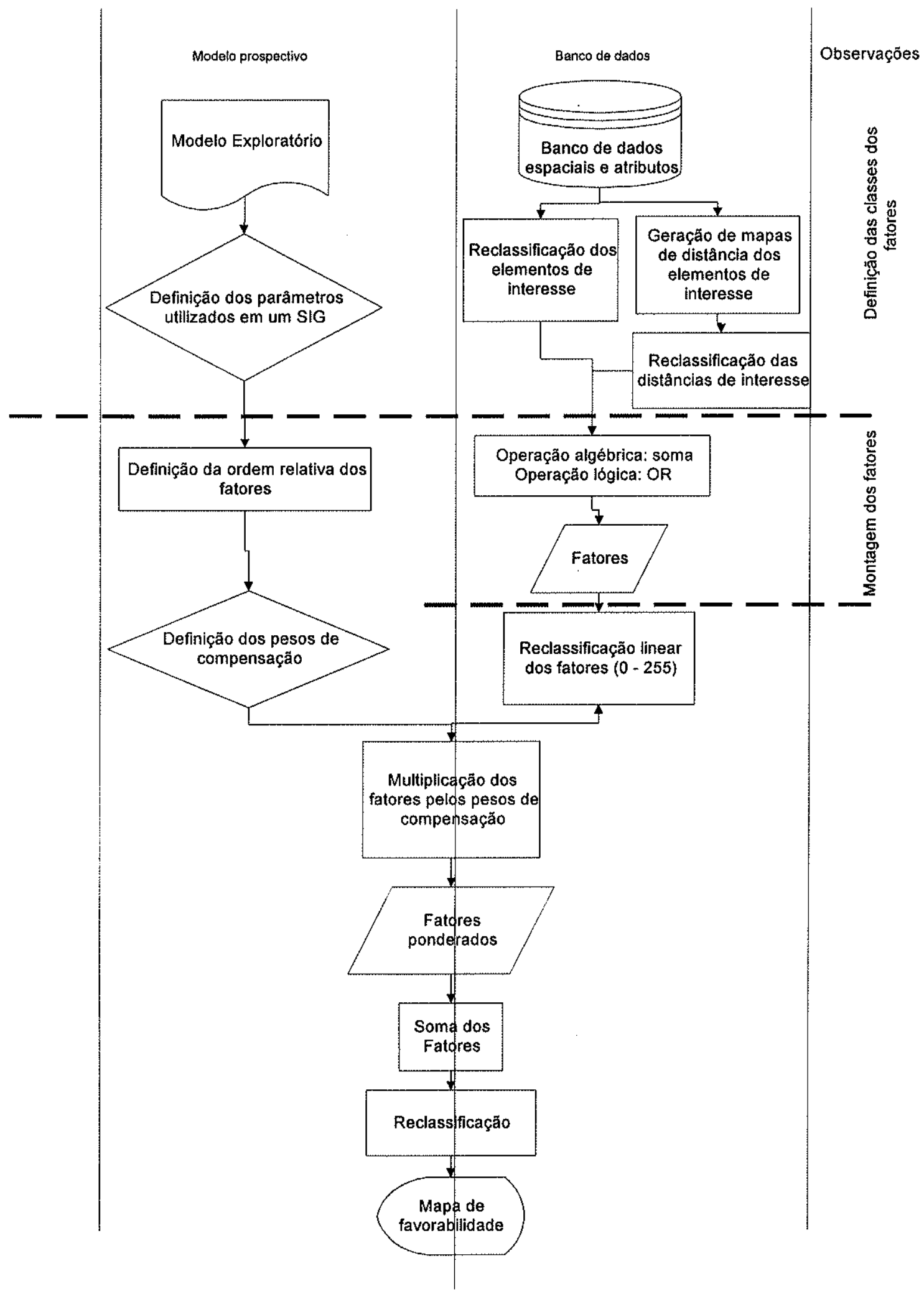

Figura 31: Fluxograma do processo de análise por combinação linear ponderada 


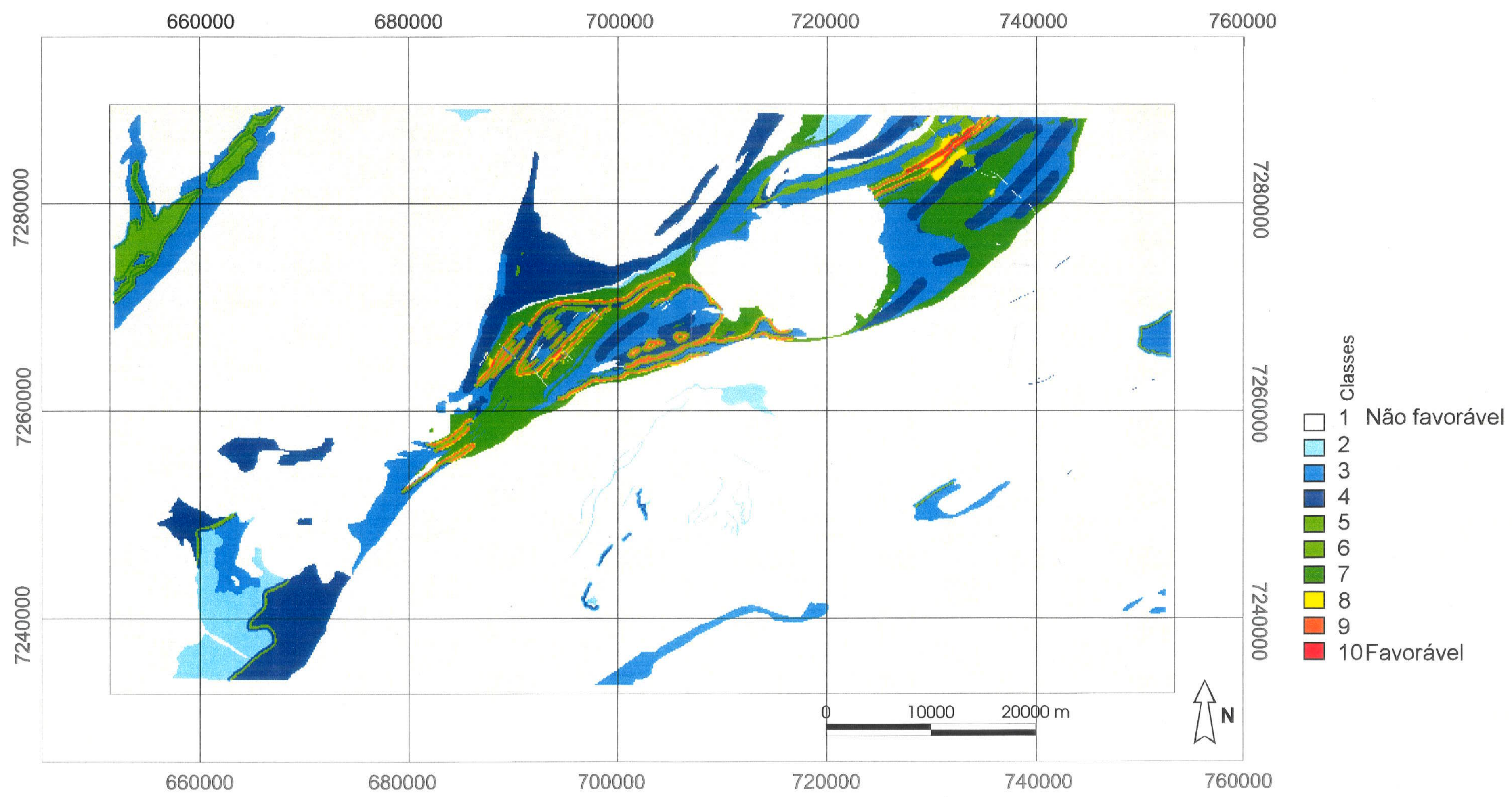




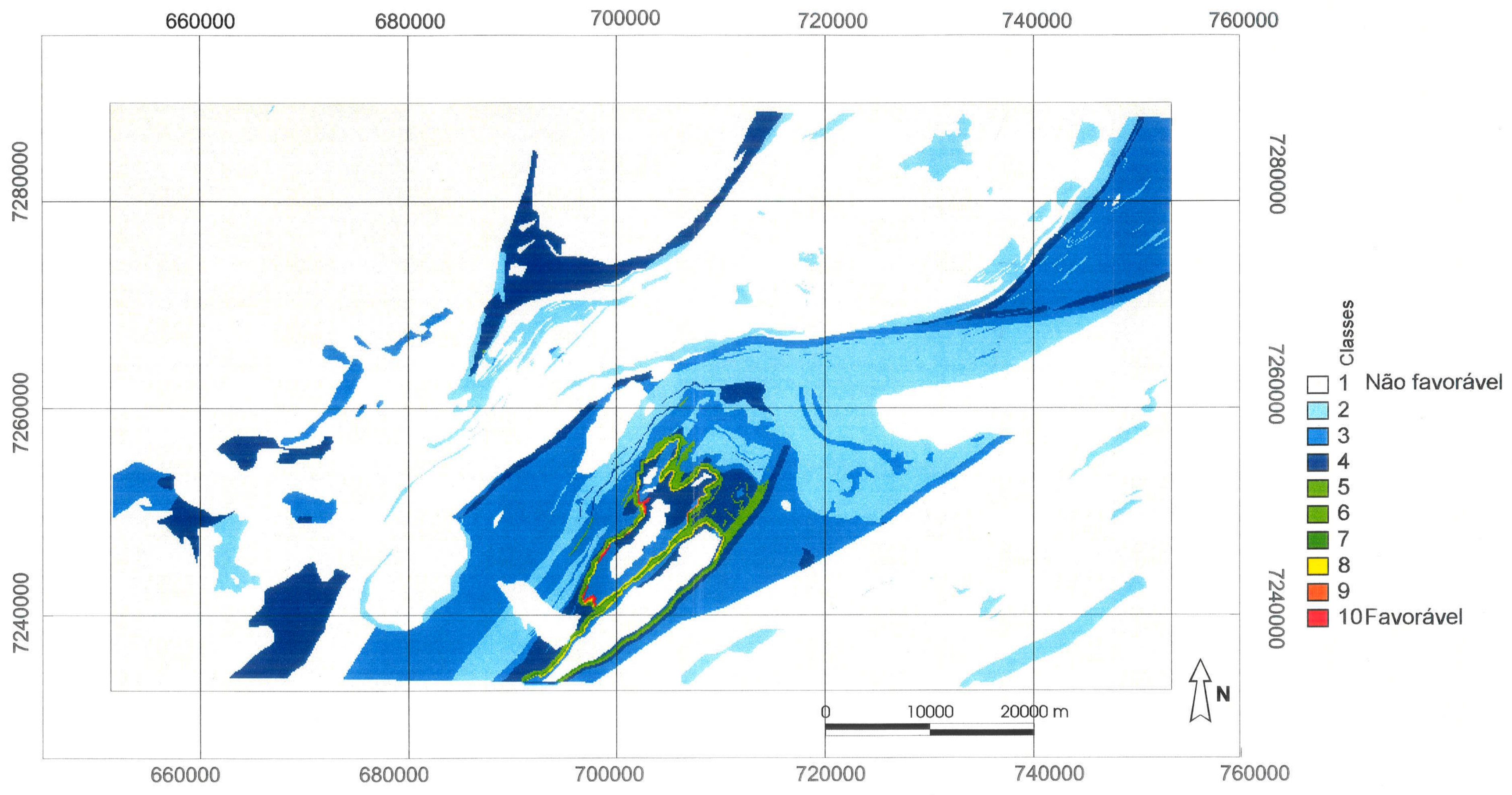




\subsection{Análise por média ponderada ordenada}

Neste método, além dos pesos dados aos fatores (pesos de compensação), como na combinação linear ponderada, são utilizados pesos de ordenação. Estes são utilizados no controle da compensação entre os fatores e são os pesos atribuídos aos fatores e que não foram utilizados na análise por combinação linear ponderada, sendo definidos numa escala de 0 a 1 . Deste modo, os pesos definidos para os fatores foram reescalonados segundo o apresentado nas tabelas a seguir.

Tabela 49: Pesos de ordenação - Panelas

\begin{tabular}{lll}
\hline Fatores & Peso definido $(0-10)$ & Peso de ordenação $(0-1)$ \\
\hline litológico & 10 & 0.33 \\
estratigráfico & 8 & 0.27 \\
geoquímico & 7 & 0.23 \\
estrutural & 5 & 0.17 \\
\hline
\end{tabular}

Tabela 50: Pesos de ordenação - Perau

\begin{tabular}{lll}
\hline Fatores & Peso definido $(0-10)$ & Peso de ordenação $(0-1)$ \\
\hline Estratigráfico & 10 & 0,36 \\
Litológico & 8 & 0,29 \\
Geoquímico & 7 & 0,25 \\
Estrutural & 3 & 0,10
\end{tabular}

A principal diferença entre as análises CLP e MPO é a consideração de uma ordem de importância distinta para cada fator, ou seja, é feita a multiplicação dos pesos de compensação pelos pesos de ordenação, os quais foram previamente definidos. Na análise MPO os ponderadores desenvolvidos para os fatores não tem somatória igual a 1 como na análise CLP.

De maneira semelhante à análise CLP, a partir dos pesos de compensação, dos pesos de cada classe e dos pesos de ordenação para cada fator, atribuídos pelos peritos, apresenta-se um quadro resumo (tabelas 53 e 54). Este quadro incorpora os pesos utilizados nas análises. O resultado apresentado na soma ponderada corresponde ao maior valor possível em um pixel derivado da sobreposição de classes de valor máximo para cada fator, como na análise CLP. Por exemplo, para saber o valor de um pixel, na análise por combinação linear 
Panelas, cujo fator litológico fosse o mármore $(2 \mathrm{~m} / 4 \mathrm{~m})$, o fator estratigráfico o Subgrupo Lajeado, o fator geoquímico o $\mathrm{Pb}$ e o fator estrutural um eixo de dobra, executa-se a seguinte operação algébrica:

$(255 \times 0,55 \times 0,33)+255(\times 0,29 \times 0,27)+(255 \times 0,14 \times 0,23)+(255 \times 0,03$ $\times 0,17)=75,76$

Todo o processo de análise por média ponderada ordenada é apresentado em fluxograma (figura 34), o qual é um esquema das atividades e subprodutos gerados durante a análise e permite comparar as diferenças entre os processos de análise CLP e MPO.

Foi feita a tabulação cruzada entre as ocorrências minerais do tipo Perau e do tipo Panelas utilizaram-se os respectivos resultados das análises por média ponderada ordenada (vide tabelas 51 e 52).

Tabela 51: Tabulação cruzada - Panelas - análise por média ponderada ordenada.

\begin{tabular}{l|llllllllll}
\hline $\begin{array}{l}\text { classes da } \\
\text { imagem MPO }\end{array}$ & 1 & 2 & 3 & 4 & 5 & 6 & 7 & 8 & 9 & 10 \\
$\begin{array}{l}\text { Células com } \\
\text { ocorrências }\end{array}$ & 0 & 0 & 0 & 0 & 0 & 6 & 52 & 14 & 9 & 1 \\
$\begin{array}{l}\text { Total de } \\
\text { células }\end{array}$ & 4197114 & 357228 & 295782 & 69337 & 49548 & 64215 & 137082 & 28264 & 7269 & 3207 \\
\hline
\end{tabular}

Tabela 52: Tabulação cruzada - Perau - análise por média ponderada ordenada.

\begin{tabular}{|c|c|c|c|c|c|c|c|c|c|c|}
\hline $\begin{array}{l}\text { classes da } \\
\text { imagem MPO }\end{array}$ & 1 & 2 & 3 & 4 & 5 & 6 & 7 & 8 & 9 & 10 \\
\hline $\begin{array}{l}\text { Células com } \\
\text { ocorrências }\end{array}$ & 0 & 0 & 1 & 0 & 0 & 2 & 0 & 1 & 3 & 0 \\
\hline $\begin{array}{l}\text { Total de } \\
\text { células }\end{array}$ & 3995420 & 503453 & 52.0283 & 140375 & 28784 & 15831 & 2875 & 233 & 1368 & 506 \\
\hline
\end{tabular}


Modelo prospectivo

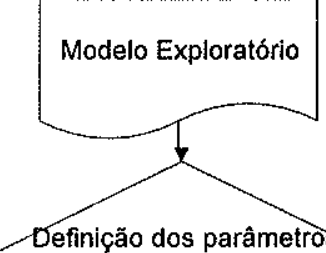

- Definição dos parâmetro

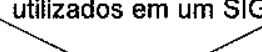

(r)

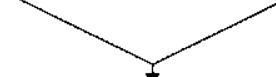

Definição dos pesos de

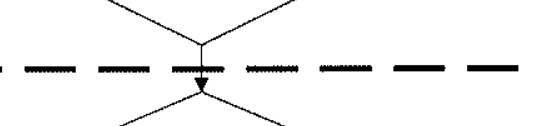

Definição dos pesos de

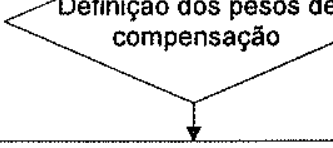

Multiplicação dos pesos de ordenação pelos pesos de compensação

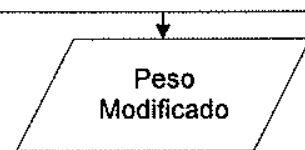

i
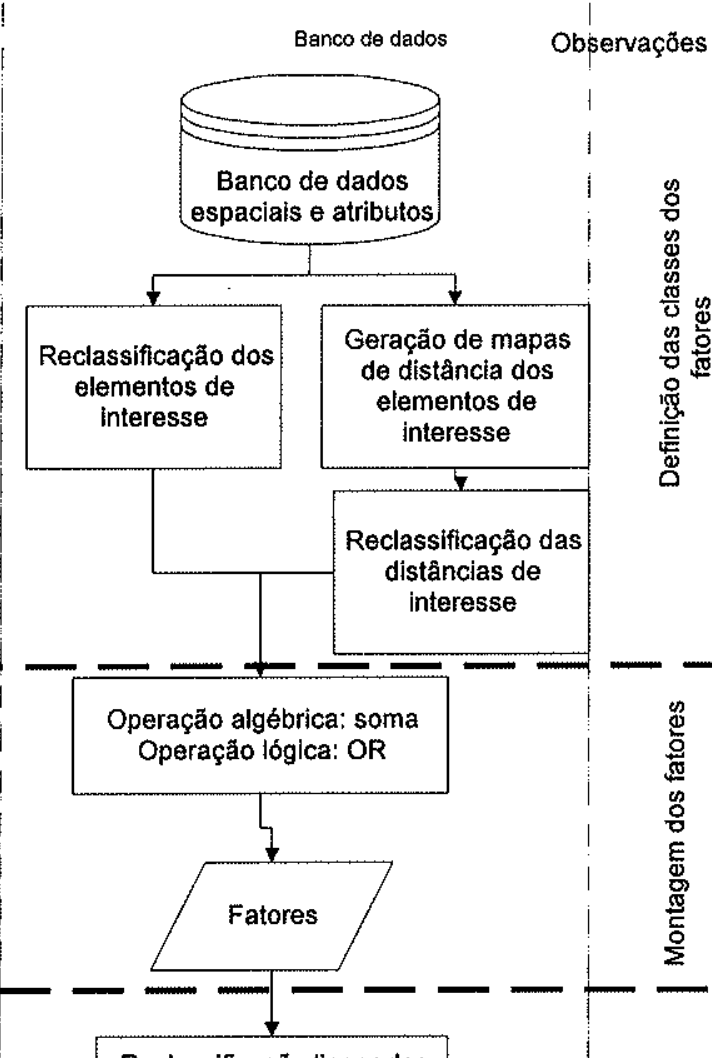

Reclassificação linear dos fatores $(0-255)$

Figura 34: Fluxograma do processo de análise por média ponderada ordenada 
Tabela 53: Quadro resumo simplificado - análise por média ponderada ordenada - Panelas

\begin{tabular}{|c|c|c|c|c|c|c|c|c|}
\hline Fator & Classe & $\begin{array}{l}\text { Peso da Classe } \\
(0-255)\end{array}$ & Peso de compensação & $\begin{array}{l}\text { Peso de ordenação } \\
\text { (peritos) }\end{array}$ & $\begin{array}{l}\text { Peso } \\
\text { Modificado }\end{array}$ & Avaliação & $\begin{array}{l}\text { Soma dos } \\
\text { Pesos }\end{array}$ & Soma ponderada \\
\hline & Mármores $(2 \mathrm{~m} / 4 \mathrm{~m})$ & 255 & & & & 45,9 & & \\
\hline & Mármores dolomíticosM & 153 & & & & 27,54 & & \\
\hline \multirow[t]{3}{*}{ Litolológico } & Cálcio-silicáticas (CS) & 102 & 0,55 & 0,33 & 0,18 & 18,36 & & \\
\hline & Micaxistos (MX) & 102 & & & & 18,36 & & \\
\hline & Contatos mámores/ xistos & 153 & & & & 27,54 & & \\
\hline \multirow[t]{3}{*}{ Estratigráfico } & Subgrupo Lajeado & 255 & & & & 20,4 & & \\
\hline & Grupo Itaiacoca & 204 & 0,28 & 0,27 & 0,08 & 16,32 & 0,295 & 75,7605 \\
\hline & Fm. Água Clara & 153 & & & & 12,24 & & \\
\hline \multirow[t]{4}{*}{ Estrutural } & Eixos de dobras & 255 & & & & 1,275 & & \\
\hline & Falhas & 127,5 & & & & 0,6375 & & \\
\hline & Lineamentos magnéticos & 51 & 0,03 & 0,17 & 0,005 & 0,255 & & \\
\hline & Eixos de máxima frequiência de fraturamento & 127,5 & & & & 0,6375 & & \\
\hline \multirow[t]{3}{*}{ Geoquimico } & $\mathrm{Pb}$ & 255 & & & & 7,65 & & \\
\hline & $\mathrm{Cu}$ & 178,5 & 0,14 & 0,23 & 0,03 & 5,355 & & \\
\hline & $\mathrm{Zn}$ & 178,5 & & & & 5,355 & & \\
\hline
\end{tabular}


Tabela 54: Quadro resumo simplificado - análise por média ponderada ordenada - Perau

\begin{tabular}{|c|c|c|c|c|c|c|c|c|}
\hline \multirow[t]{3}{*}{ Fator } & Classe & Peso da Classe & Peso de compensação & Peso de ordenação & Peso & Avaliação & Soma dos & Soma ponderada \\
\hline & Carbonato xistos (CS) & $\begin{array}{l}(0-200) \\
255\end{array}$ & & & & 19,227 & & \\
\hline & Micaxistos (MX) & 153 & & & & 11,5362 & & \\
\hline \multirow[t]{2}{*}{ Litolológico } & Xistos (AS/AF, X) & 76.5 & 0,26 & 0,29 & 0,0754 & 5,7681 & & \\
\hline & Metavulcânicas (B) & 51 & & & & 3,8454 & & \\
\hline \multirow[t]{3}{*}{ Estratigráfico } & Formaçăo Perau (vp) & 204 & & & & 41,1264 & & \\
\hline & Subgrupo Ribeira (v) & 127,5 & 0,56 & 0,36 & 0,2016 & 25,704 & & \\
\hline & $\begin{array}{l}\text { Corredor externo no contato quartzitos/pelitos } \\
\text { da Formaçăo Perau }\end{array}$ & 255 & & & & 51,408 & 1 & 255 \\
\hline \multirow[t]{3}{*}{ Estrutural } & Falhas & 255 & & & & 1,02 & & \\
\hline & Lineamentos magnéticos & 51 & 0,04 & 0,10 & 0,004 & 0,204 & & \\
\hline & Zonas de máxima frequêencia de fraturamento & 102 & & & & 0,408 & & \\
\hline \multirow[t]{3}{*}{ Geoquimico } & $\mathrm{Pb}$ & 255 & & & & 8,925 & & \\
\hline & $\mathrm{Cu}$ & 127,5 & 0,14 & 0,25 & 0,035 & 4,4625 & & \\
\hline & $\mathrm{Zn}$ & 127,5 & & & & 4,4625 & & \\
\hline
\end{tabular}




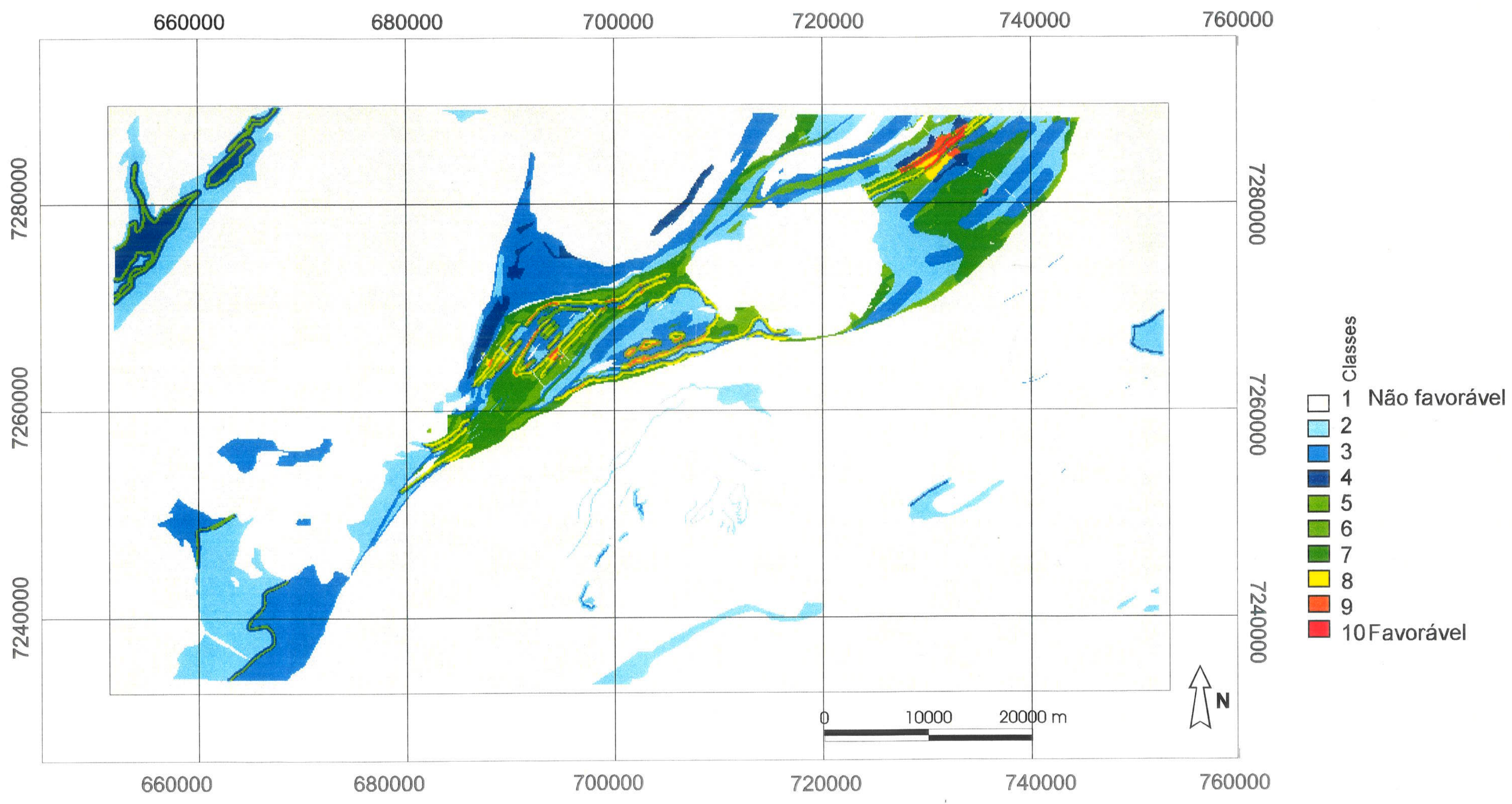




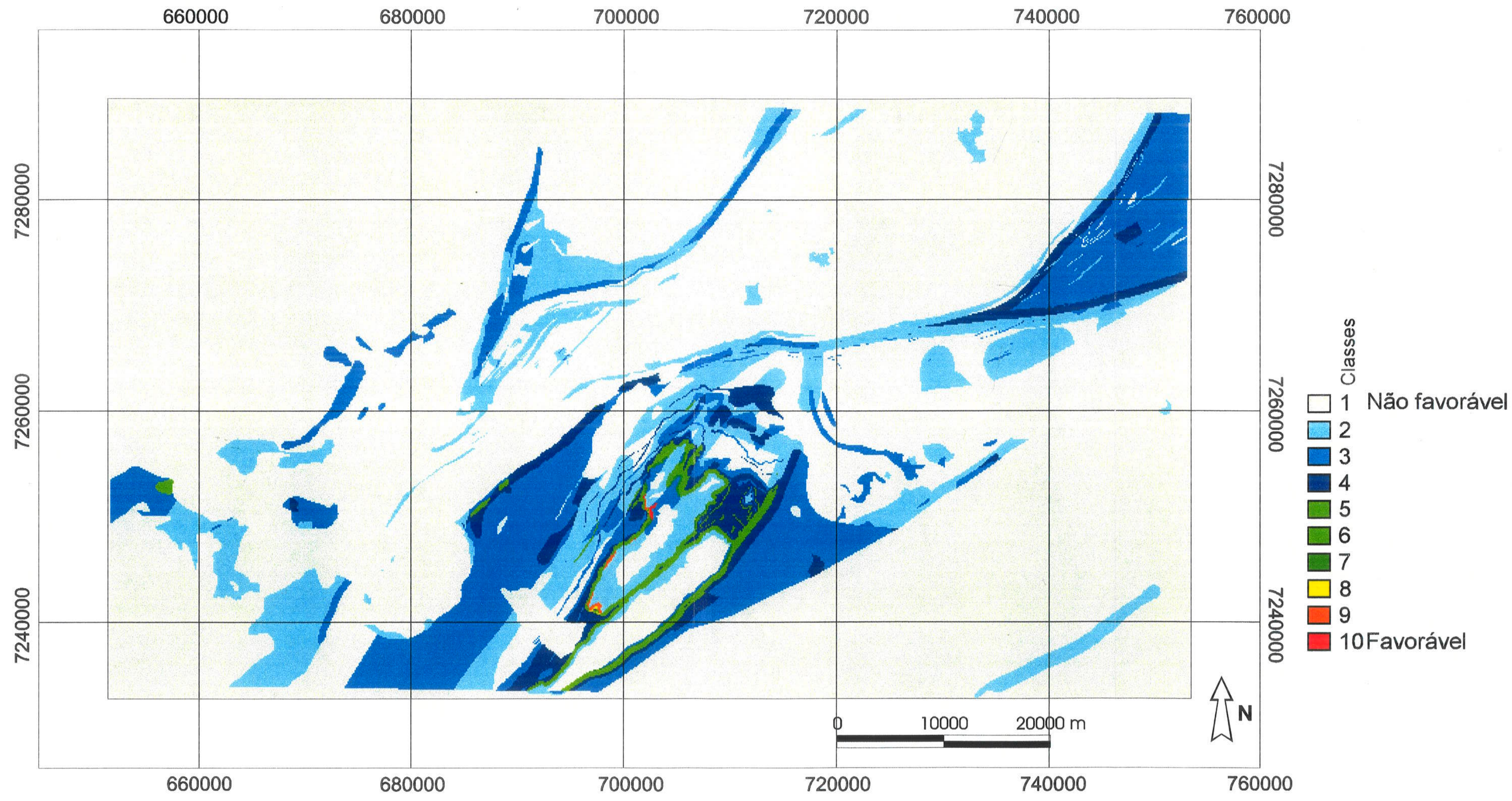

Figura 36: Mapa de favorabilidade - Análise por média ponderada ordenada - Perau. 


\subsection{Comparação entre as análises por combinação linear ponderada e média ponderada ordenada}

A comparação foi feita a partir de um mesmo modelo prospectivo comparando-se dois métodos de análise diferentes para a mesma área. Executaram-se duas comparações, uma para o modelo Perau e outra para o Panelas, observando-se os métodos por combinação linear ponderada e média ponderada ordenada.

A comparação entre os métodos de análise foi feita para verificar a consistência dos resultados, ou seja, buscou-se definir, dado um mesmo modelo prospectivo, quais as áreas de mesma classe de favorabilidade que eram coincidentes segundo diferentes métodos de análise. Além disso, definiu-se a correlação entre os mapas de favorabilidade resultantes das análises por tabulação cruzada.

As tabulações cruzadas entre as imagens resultantes das análises são apresentadas nas tabelas 55 e 56 . Os números em destaque correspondem aos maiores valores proporcionais por classe.

Tabela 55: Tabulação cruzada proporcional - tipo Panelas

\begin{tabular}{|c|c|c|c|c|c|c|c|c|c|c|c|c|}
\hline & & & & & Média $p$ & onderad & ordena & & & & & \\
\hline & Classes & 1 & 2 & 3 & 4 & 5 & 6 & 7 & 8 & 9 & 10 & Total \\
\hline ర్ర & 1 & 0,8055 & 0 & 0 & 0 & 0 & 0 & 0 & 0 & 0 & 0 & 0,8055 \\
\hline$\frac{110}{0}$ & 2 & 0,0002 & 0,0168 & 0 & 0 & 0 & 0 & 0 & 0 & 0 & 0 & 0,017 \\
\hline ᄃิ & 3 & 0 & 0,0518 & 0,0083 & 0 & 0 & 0 & 0 & 0 & 0 & 0 & 0,06 \\
\hline $\bar{\pi}$ & 4 & 0 & 0 & 0,0485 & 0,0054 & 0 & 0 & 0 & 0 & 0 & 0 & 0,0539 \\
\hline$\stackrel{\oplus}{\leftrightarrows}$ & 5 & 0 & 0 & 0 & 0,0079 & 0,004 & 0 & 0 & 0 & 0 & 0 & 0,0119 \\
\hline 0 & 6 & 0 & 0 & 0 & 0 & 0,0055 & 0,0006 & 0 & 0 & 0 & 0 & 0,0061 \\
\hline$y$ & 7 & 0 & 0 & 0 & 0 & 0 & 0,0117 & 0,0254 & 0 & 0 & 0 & 0,0372 \\
\hline 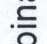 & 8 & 0 & 0 & 0 & 0 & 0 & 0 & 0,0009 & 0,0012 & 0,0004 & 0 & 0,0025 \\
\hline $\bar{\varepsilon}$ & 9 & 0 & 0 & 0 & 0 & 0 & 0 & 0 & 0,0042 & 0,001 & 0 & 0,0052 \\
\hline & 10 & 0 & 0 & 0 & 0 & 0 & 0 & 0 & 0 & 0 & 0,0006 & 0,0006 \\
\hline & Total & 0,8057 & 0,0686 & 0,0568 & 0,0133 & 0,0095 & 0,0123 & 0,0263 & 0,0054 & 0,0014 & 0,0006 & 1 \\
\hline
\end{tabular}

Obs: Os valores no campo "classes"correspondem as classes de favorabilidade. Os valores em vermelho correspondem aos maiores valores proporcionais por classe. 
Tabela 56: Tabulação cruzada proporcional - tipo Perau

\begin{tabular}{|c|c|c|c|c|c|c|c|c|c|c|c|c|}
\hline & & & & & Média p & nderada & ordena & & & & & \\
\hline & Classes & 1 & 2 & 3 & 4 & 5 & 6 & 7 & 8 & 9 & $10 T$ & Total \\
\hline శ్రై & 1 & 0,7092 & 0 & 0 & 0 & 0 & 0 & 0 & 0 & 0 & 0 & 0,7092 \\
\hline ग्ञ & 2 & 0,0578 & 0,0512 & 0 & 0 & 0 & 0 & 0 & 0 & 0 & 0 & 0,109 \\
\hline ธ్ & 3 & 0 & 0,0179 & 0,0897 & 0,008 & 0 & 0 & 0 & 0 & 0 & 0 & 0,1156 \\
\hline స & 4 & 0 & 0,0275 & 0,0102 & 0,0172 & 0,0011 & 0 & 0 & 0 & 0 & 0 & 0,0559 \\
\hline$\stackrel{\oplus}{\subseteq}$ & 5 & 0 & 0 & 0 & 0,0014 & 0,0023 & 0,0001 & 0 & 0 & 0 & 0 & 0,0038 \\
\hline 疍 & 6 & 0 & 0 & 0 & 0,0003 & 0,001 & 0,0006 & 0 & 0 & 0 & 0 & 0,0019 \\
\hline ర్ల & 7 & 0 & 0 & 0 & 0 & 0,0012 & 0,0008 & 0,0002 & 0 & 0 & 0 & 0,0022 \\
\hline 등 & 8 & 0 & 0 & 0 & 0 & 0 & 0,0015 & 0,0003 & 0 & 0 & 0 & 0,0019 \\
\hline ్ㅗ & 9 & 0 & 0 & 0 & 0 & 0 & 0 & 0 & 0 & 0,0001 & 0 & 0,0001 \\
\hline$c$ & 10 & 0 & 0 & 0 & 0 & 0 & 0 & 0 & 0 & 0,0002 & 0,0001 & 0,0003 \\
\hline & Total & 0,767 & 0,0966 & 0,0999 & 0,0269 & 0,0055 & 0,003 & 0,0006 & 0 & 0,0003 & 0,0001 & 1 \\
\hline
\end{tabular}

Obs: Os valores no campo "classes"correspondem as classes de favorabilidade. Os valores em vermelho correspondem aos maiores valores proporcionais por classe.

As matrizes nas tabelas 55 e 56 apresentam a distribuição proporcional de pixels classificados segundo a correspondência entre as análises por média ponderada ordenada e combinação linear ponderada. Se a correlação entre as duas análises fosse ideal (100 \% de correlação) teriamos uma matriz cuja diagonal principal estaria preenchida com os valores correspondentes a proporção de pixels por classes, as outras posições da matriz estariam em branco. Nota-se nas matrizes apresentadas (tabelas 55 e 56) que há uma tendência de preenchimento dos valores ao longo da diagonal principal, embora os maiores valores proporcionais de pixels nem sempre estejam na diagonal principal.

A comparação espacial entre os dois tipos de análise é apresentada nas figuras 37 e 38, para os modelos Panelas e Perau respectivamente. Estas figuras apresentam as áreas onde há coincidência de valores de favorabilidade para os dois modelos estudados. Em cores estão as classes de favorabilidade; a cor branca corresponde as áreas onde não há coincidência entre os métodos. Observa-se que para os dois casos, Perau e Panelas, a classe 1 (não favorável) é coincidente em praticamente toda sua extensão. A partir da classe de favorabilidade 2 até a classe 10 pode-se observar o decréscimo no número de áreas coincidentes. Nas figuras 39 e 40 são apresentados detalhes comparativos entre as análises para os modelo Perau e Panelas. Os números plotados indicam os valores das classes de favorabilidade e os pontos verdes correspondem as ocorrências minerais filonares e estratiformes, correspondentes aos modelos Panelas e Perau respectivamente. 


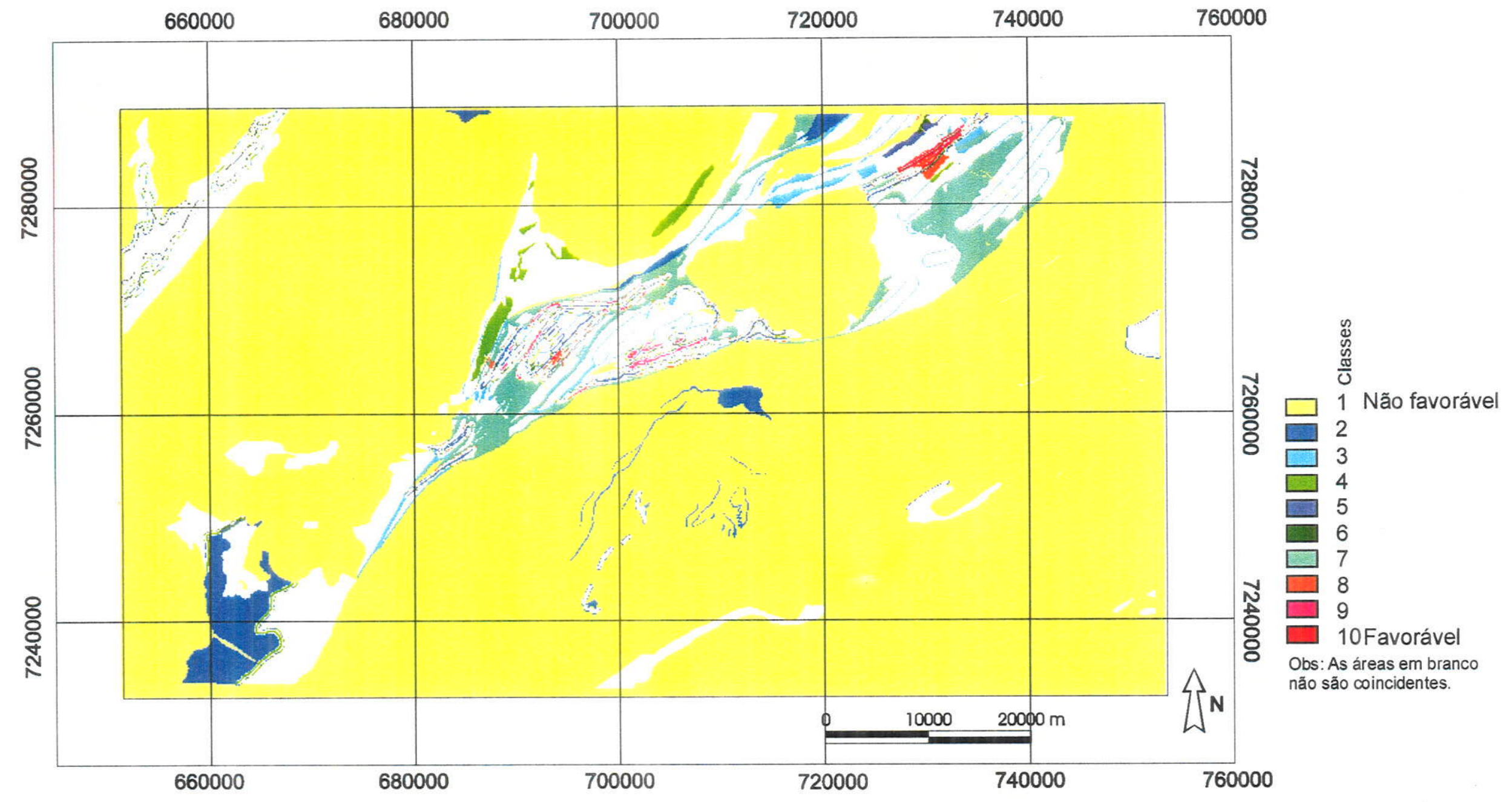

Figura 37: Áreas coincidentes entre as análises de favorabilidade por média ponderada ordenada e combinação linear ponderada para o tipo Panelas. 


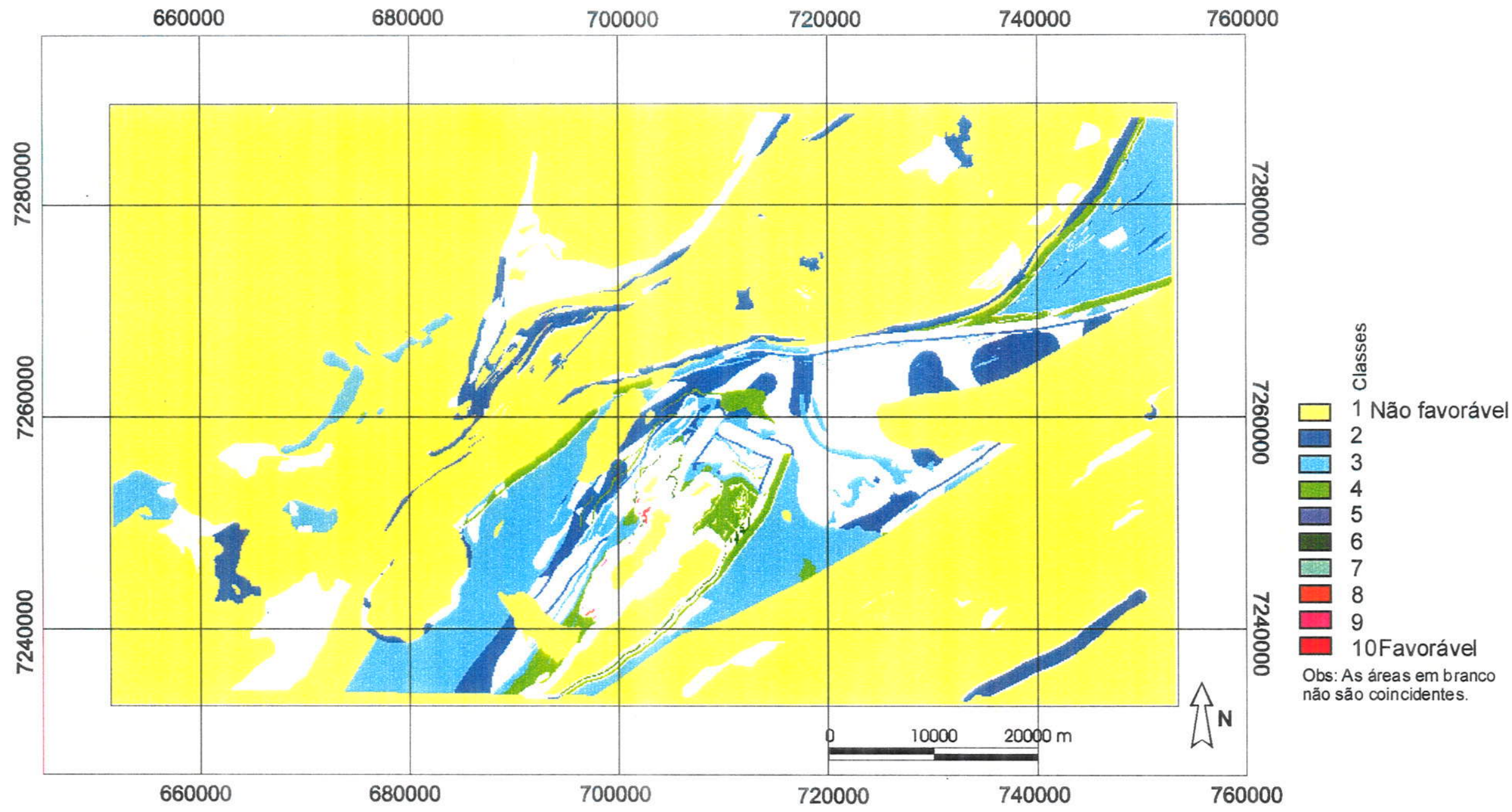

Figura 38: Áreas coincidentes entre as análise de favorabilidade por média ponderada ordenada e combinação linear ponderada para 0 tipo Perau. 
Combinação linear ponderada

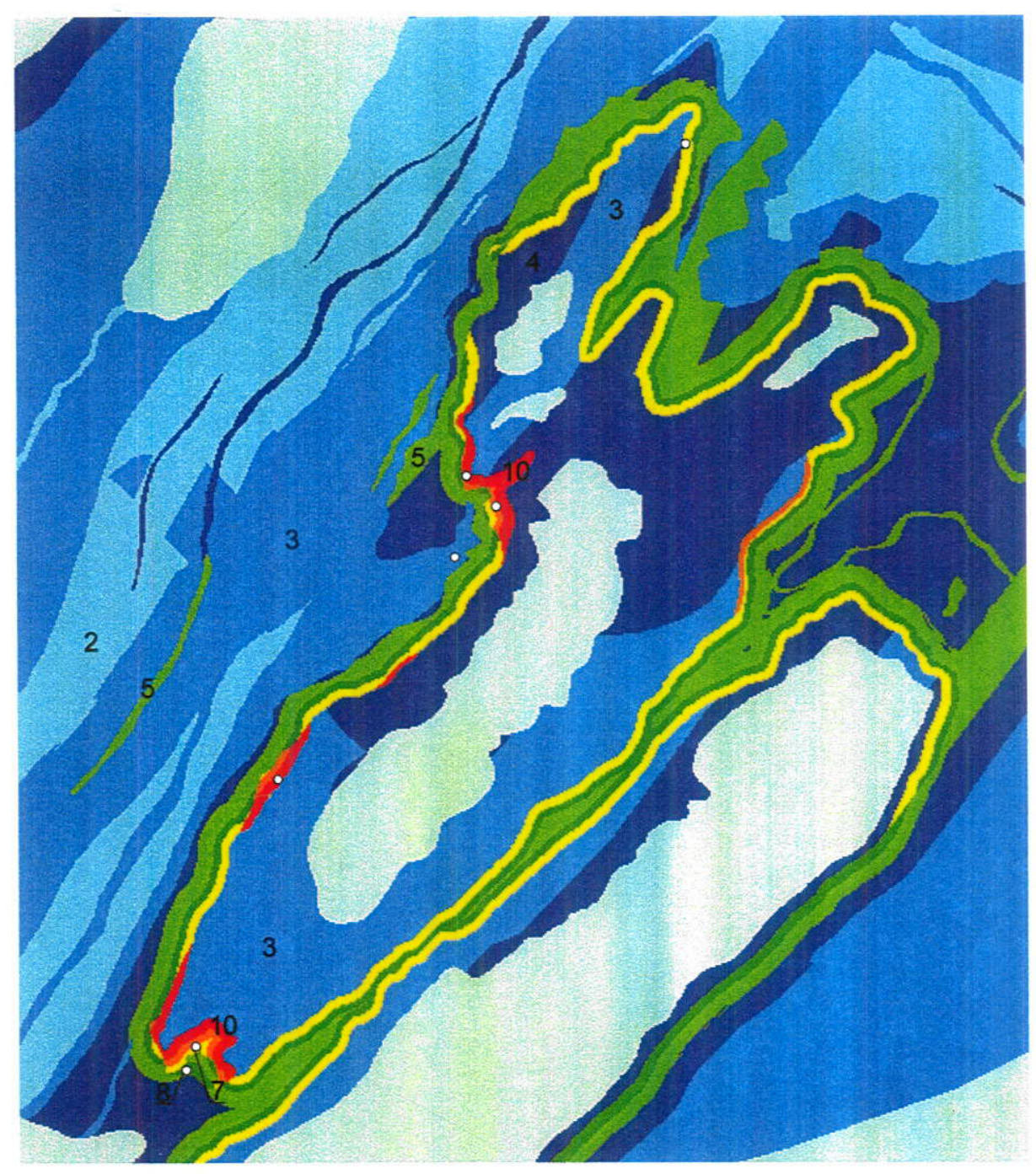

Média Ponderada Ordenada

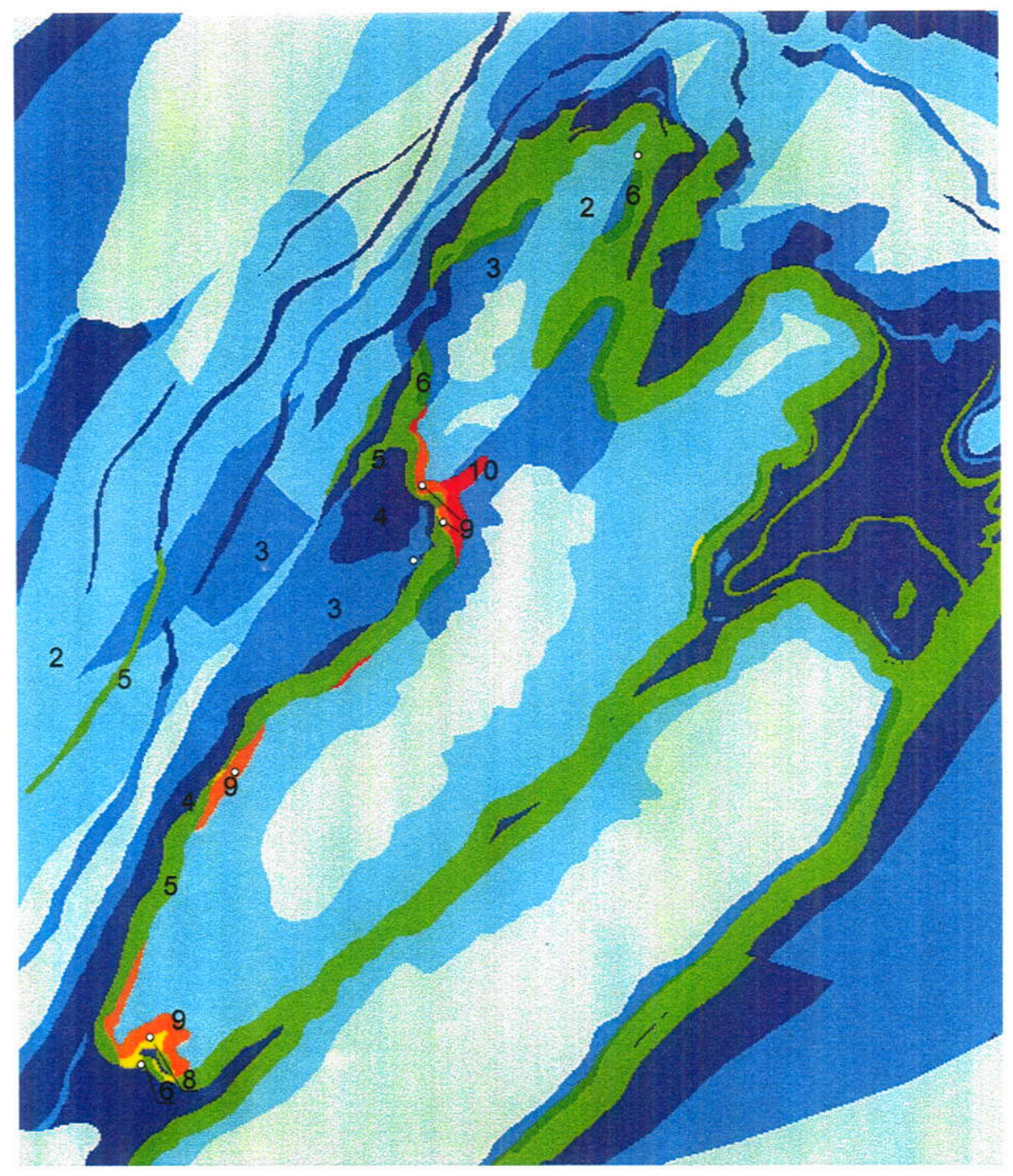

Obs: Pontos brancos correspondem às ocorrências filonares e os valores correspondem às classes de favorabilidade..

Figura 39: Detalhe das análises por Média ponderada ordenada e combinação linear ponderada para o tipo Perau, na região da Fm. Perau. 
Combinação linear ponderada

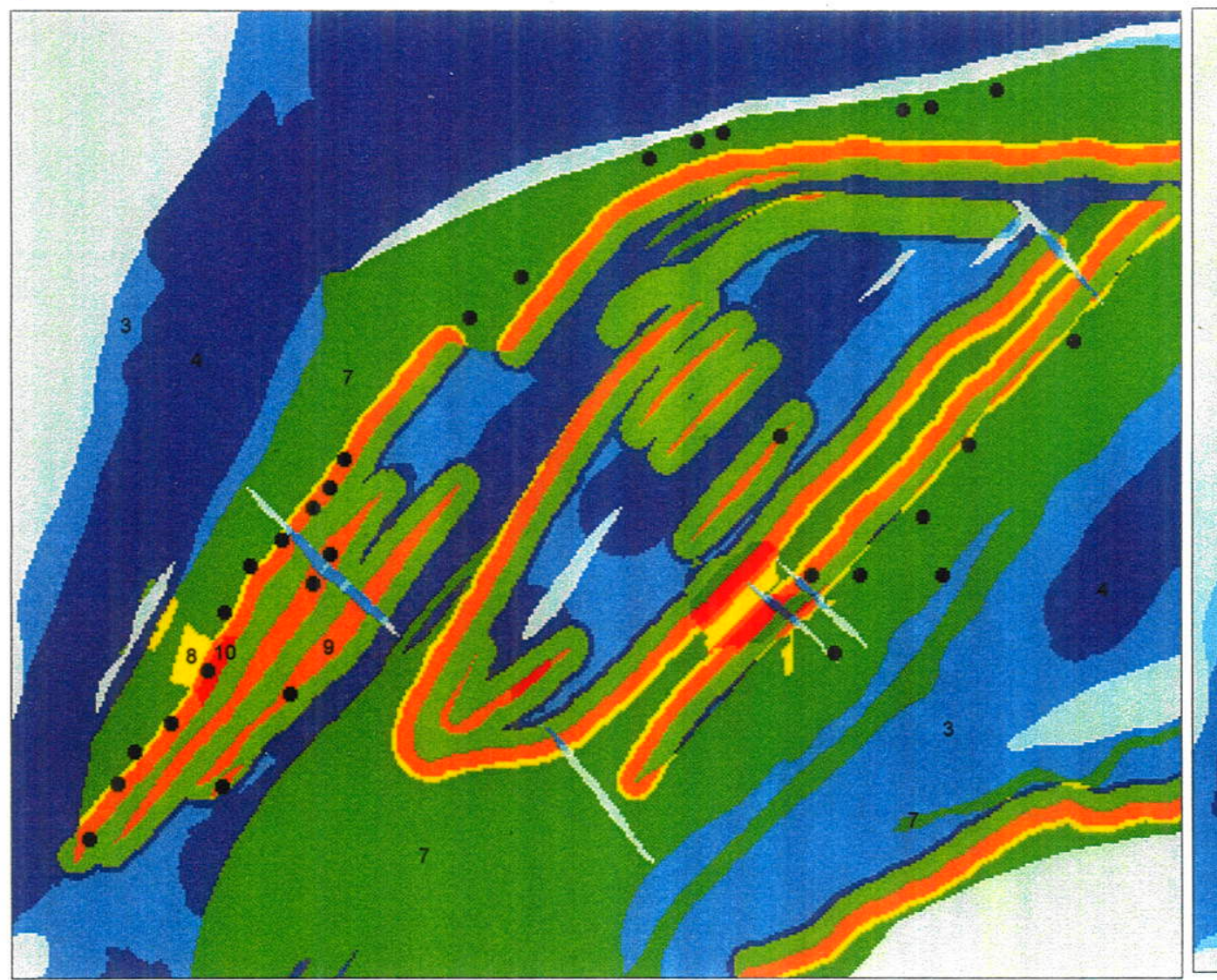

Média ponderada ordenada

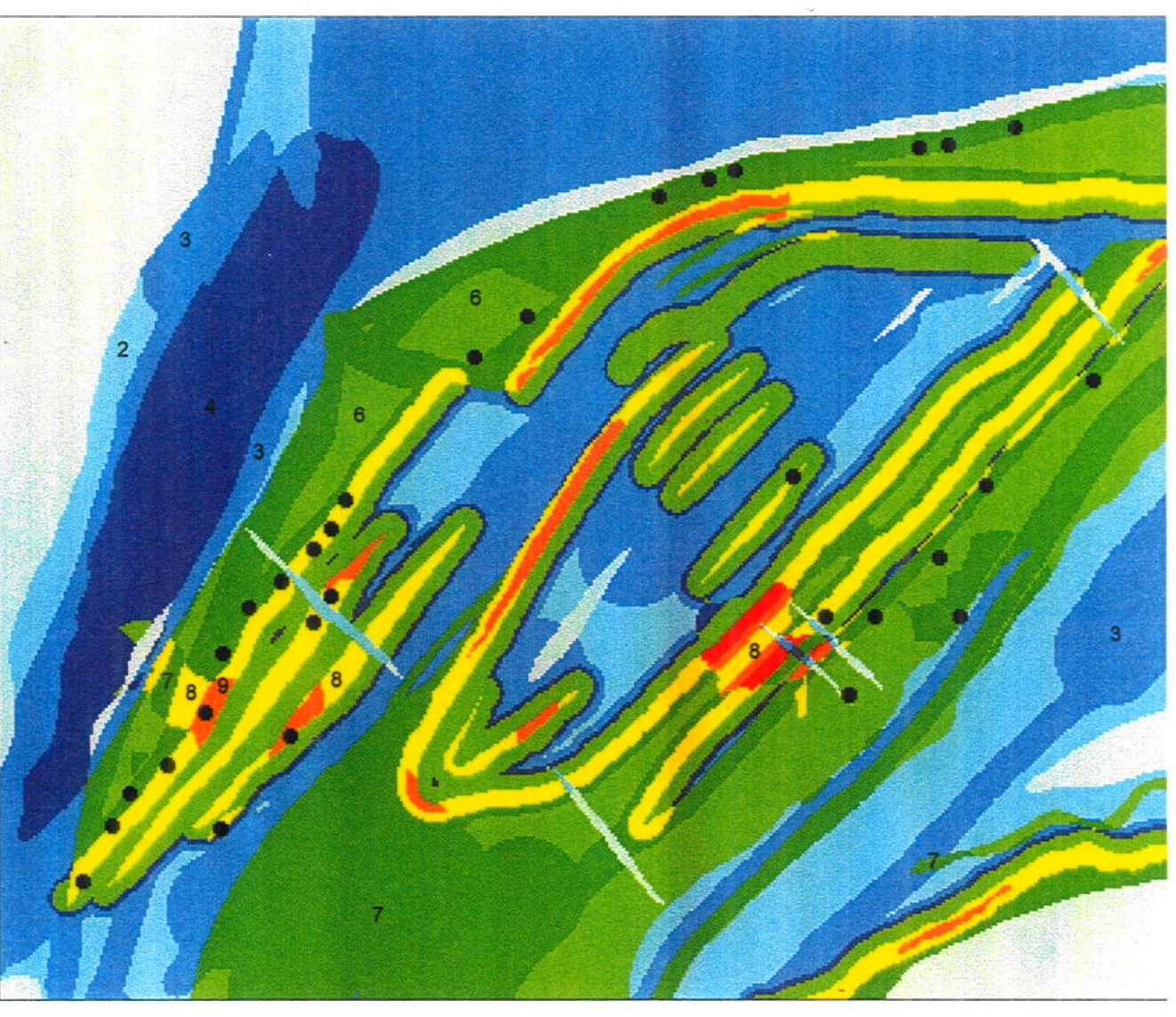

Obs: Pontos pretos correspondem às ocorrências filonares e os valores correspondem às classes de favorabilidade.. 


\section{CONSIDERAÇÕES FINAIS}

\subsection{Conclusões}

Os resultados das análises executadas serviram tanto para o teste dos modelos prospectivos adotados, quanto para a comparação entre os diferentes métodos de análise por geoprocessamento. A seguir apresentam-se as conclusões baseadas nos resultados e nos métodos empregados durante 0 desenvolvimento do trabalho:

1. A análise booleana caracterizou-se por definir extremos dentro das possibilidades previstas nos modelos, ou seja, este tipo de análise gerou um mapa apenas com as áreas onde havia sobreposição de todas as informações previstas nos parâmetros prospectivos. A tabulação cruzada entre os mapas de favorabilidade e as ocorrências minerais estratiformes e filonares para os modelos Perau e Panelas, respectivamente, demonstrou que a análise booleana não é adequada para se testar modelos prospectivos por geoprocessamento. Esta conclusão é reforçada quando feita a comparação entre a análise booleana e os outros tipos de análise executados.

2. Para o modelo Panelas, as análises por combinação linear ponderada (CLP) e por média ponderada ordenada (MPO), apresentaram um bom resultado, pois nenhuma ocorrência mineral ficou em área de baixa favorabilidade, ou seja, em área cuja classe estivesse no intervalo 1 a 5 . Em ambos os casos mais de $60 \%$ das ocorrências caíram na classe 7 , a qual indica boa a alta favorabilidade. De uma a duas ocorrências cairam em áreas de classe 10, lembrando-se que esta classe tem pouca extensão em área. Conclui-se que para a definição de alvos para pesquisa mais detalhada, no caso do tipo Panelas, as áreas correspondentes a classes maiores ou iguais a sete são as mais adequadas do ponto de vista geológico.

3. Para o modelo Panelas, são apresentados resultados semelhantes segundo os dois tipos de análise (CLP e MPO). Em termos absolutos há baixa correspondência dos valores de favorabilidade entre os dois métodos. Observando-se a matriz de correlação entre as análises (tabela 55) é bastante 
nítido o preenchimento da diagonal principal, demonstrando uma forte tendência de correlação entre os dois métodos.

4. Para o modelo Perau, as análises (CLP e MPO) também apresentaram um resultado positivo. Contudo, o número de ocorrências conhecidas é pequeno (7 ocorrências), o que pode causar um aumento substancial do erro na análise dos resultados. Nos dois casos, seis de um total de sete ocorrências caíram em classes de boa a alta favorabilidade, cujos valores eram maiores que 6 .

5. No caso da análise para o modelo Perau pode-se definir como áreas-alvo para pesquisa aquelas cujas classes de favorabilidade tenham valores maiores ou iguais a seis.

6. As duas análises (CLP e MPO), no caso do modelo Perau, têm distribuição espacial e ordem de grandeza de valores de favorabilidade coerentes entre si. Embora os mapas de favorabilidade não sejam idênticos, estes demonstram as mesmas tendências em termos de distribuição.

7. A análise de favorabilidade, utilizando-se a média ponderada ordenada (MPO), mostrou-se um processo mais flexível do que a análise por combinação linear ponderada (CLP). Além disso a análise MPO discrimina melhor, espacialmente, as classes de favorabilidade, ou seja, a análise MPO distingue um número maior de áreas de favorabilidade diferentes em relação a análise CLP.

8. A análise CLP caracterizou-se pela compensação nos pesos dos fatores, apresentando um resultado mais conservador do que a análise MPO. Também caracteriza-se pela facilidade e simplicidade de aplicação com resultados bastante parecidos com a análise MPO.

9. Entre os SIGs utilizados destacam-se o Idrisi e o Arclnfo. O Idrisi é um sistema que utiliza basicamente arquivos raster e que é mais adequado às etapas de análise dos dados. O Arclnfo é um sistema basicamente vetorial e se mostrou adequado às etapas de montagem e gerenciamento de bancos de dados, especialmente dos bancos que envolvem uma grande quantidade de informações. Uma diferença conceitual importante entre esses sistemas é verificada quando se deseja realizar operações entre niveis de informação diferentes ou em apenas um nivel de informação: o Idrisi aplica os operadores diretamente na imagem correspondente ao nivel de informação; o Arclnfo 
aplica os operadores em um banco de dados textual, correspondente ao nivel de informação analisado.

10. Os resultados obtidos mostram bastante coerência entre os parâmetros prospectivos adotados $\mathrm{e}$ as ocorrências minerais. Os métodos de análise utilizados mostraram-se adequados às condições do Vale do Ribeira e aos dados disponíveis.

11. Em relação as hipóteses definidas para os modelos prospectivos adotados, verificou-se, no caso do modelo Perau que as áreas mais favoráveis estão associadas aos elementos estratigráficos e litológicos, ou seja, estas áreas associam-se à presença de metassedimentos, especialmente ao contato entre quartzitos e xistos da Formação Perau.

12. Os contatos entre xistos e litologias carbonáticas mostrou-se eficiente na definição de áreas favoráveis, para o tipo Panelas, principalmente na região que abrange as minas do Rocha, Paqueiro e Quarenta Oitavas, o que é um reflexo dos controles lito-estruturais destas mineralizações.

13. Finalmente, a definição de áreas de fraqueza estrutural segundo a interpretação de feições retilíneas de drenagem não foi suficientemente detalhada em relação à dimensão das mineralizações presentes na área. $O$ produto obtido demonstra a relação desta interpretação com as estruturais regionais, não sendo o mais adequado para a análise na escala utilizada neste estudo.

\subsection{Recomendações}

É recomendável a utilização do geoprocessamento, na análise de favorabilidade, pois esta permite o uso de técnicas não aplicáveis manualmente e é fundamental na otimização dos trabalhos de organização e manutenção de grandes bancos de dados espaciais, gerados durante os trabalhos de prospecção mineral.

Devido ao resultado positivo apresentado, recomenda-se a utilização dos métodos aplicados neste trabalho em áreas com condições semelhantes às estudadas. Em áreas desconhecidas ou com poucos dados geológicos, 
recomenda-se a utilização de sensoriamento remoto e aerogeofísica em conjunto com geoprocessamento (SIG) balizada por um modelo prospectivo bem definido, seguindo os métodos apresentados, o que pode gerar um mapa de áreas favoráveis a baixos custos, com as seguintes ressalvas:

- o resultado teria um nivel de confiança mais baixo;

- não haveria possibilidade de se testar os resultados obtidos sem pesquisa detalhada.

Alguns fatores geológicos para o modelo prospectivo tipo Perau não foram utilizados, tais como a presença de formação ferrifera na capa dos depósitos e os níveis baritiferos. Estes fatores não foram utilizados devido à incompatibilidade entre a escala de trabalho utilizada e a escala de mapeamento necessária para a deteç̧ão destes. Recomenda-se a utilização destes fatores na forma de pontos de ocorrência mineral de barita, hematita ou óxidos de ferrto disponíveis no banco de dados CPRM-Microsiga (1994).

É recomendada a utilização de dados aerogeofísicos, em escala de maior detalhe, visando a detecção de elementos indicadores de mineralização como padrões de alteração hidrotermal a partir de dados gamaespectrométricos.

No caso do modelo Panelas a aplicação dos métodos utilizados em áreas menores (escala de maior detalhe), acompanhado de levantamentos de campo de dados estruturais, permitiria uma melhor definição de alvos dentro das unidades litoestratigráficas carbonáticas, refinando-se a separação das áreas de alta favorabilidade. Do mesmo modo, recomenda-se a interpretacão dos dados de zonas de fraturamento, em escala de maior detalhe (1:25.000), considerando-se as atitudes dos filöes descritas na bibliografia. 


\section{REFERÊNCIAS BIBLIOGRÁFICAS}

AKIMA, H. (1978) A method of bivariate interpolation and smooth surface fitting for irregulary distributed data points. ACM Transactions on Mathematical Software v. 4 , n. 2, p. 148-159.

ALMEIDA, F.F.M. (1956) Novas ocorrências de fósseis no Pré-Cambriano brasileiro. Anais da Academia Brasileira de Ciências, v. 29, n. 1, p. 63-72.

ALIYEV, A. (1979) Regional fracturing of the Pamirs and its metallogenic significance. Doklady Akad. Nauk, USSR, v. 250, p. 90-93.

ARONOFF, S. (1989) Geographic Information Systems: A Management Perspective. Ottawa, WDL Publications, 294p.

BARBOSA, A.F. ; GUIMARÃES, J.E.P. (1946) Contribuição ao conhecimento da Província Metalogenética da região da Ribeira, Estado de São Paulo, Brasil. In: CONGRESSO PANAMERICANO DE ENGENHARIA DE MINAS E GEOLOGIA, 2., Petrópolis, 1946. Anais. Petrópolis, v. 2, p. 35-100.

BARBOSA, A. F. (1941) Geologia e Petrologia na região de Apiai, Estado de São Paulo. São Paulo, 76 p. (Tese para concurso da cadeira de "Geologia, Petrografia e Mineralogia") - Escola Politécnica, Universidade de São Paulo.

BARBOSA, A. F. (1955) Estrutura e Gênese da Jazida de Chumbo de Furnas, Estado de São Paulo. São Paulo, 52 p. (Tese de Concurso de Livre Docência da Cadeira de "Jazidas Minerais, Legislação de Minas") - Escola Politécnica, Universidade São Paulo.

BARBOUR, A.P. ; OLIVEIRA, M.A.F. (1979) Pb, Zn, Cu e Ba do Distrito Perau Modelo Sedimentar para Sulfetos do Vale do Ribeira. Boletim IG, v. 10, p. 97120. 
BARBOUR, A.P. ; OLIVEIRA, M.A.D. ; HYPOLITO, R. (1984) Geologia e Gênese do depósito estratiforme de $\mathrm{Pb}$ da Mina da Barrinha, Vale do Ribeira, PR. In: CONGRESSO BRASILEIRO DE GEOLOGIA, 23., Rio de Janeiro, 1984. Anais. Rio de Janeiro, SBG, p. 3641- 3657.

BARBOUR, A.P. ; MACEDO, A.B. ; HYPOLITO, R. (1988) Correlação de elementos prata, chumbo, zinco e ferro com bário em algumas jazidas sulfetadas do Vale do Ribeira, Estado de São Paulo e Paraná. Boletim IG USP, Série Científica, v. 19, p. 1-21.

BARBOUR, A.P. ; BRITO NEVES, B.B. ; MEDEIROS, R.A. (1990) Algumas implicações tectônicas na gênese das mineralizações sulfetadas do tipo Panelas no Vale do Ribeira, SP, PR. Revista Brasileira de Geociências, v. 20, n. $1-4$, p. $46-54$.

BARBOUR, A.P.; MACEDO, A.B. (1991) Contribuição ao Conhecimento da Distribuição Espacial dos elementos $\mathrm{Cu}, \mathrm{Pb}, \mathrm{Zn}, \mathrm{Fe}$, e Ba no distrito do Perau, PR. Boletim IG - USP. Publicacão Especial, Jornadas Científicas, v. 9, p. 103106.

BASTIAN, L. (1946) Ocorrências de minérios de chumbo em Lajeado, município de Iporanga, Estado de São Paulo. In: Congresso Panamericano de Engenharia de Minas e Geologia, 2., Petrópolis, 1946. Anais. Petrópolis, v. 2, p. 199-221.

BATES, R.L. \& JACKSON, A.J., (1987) Glossary of Geology, American Geological Institute.

BEDELL, R.L. (1994) GIS for the geosciences - shortcourse. Sparks, NV, Homestake Mining Co., $193 \mathrm{p}$.

BEISL, C.H. (1996) Integração de dados de sensoriamento remoto, geologia, gravimetria e topografia para o estudo do arcabouço estrutural em uma parte 
do compartimento nordeste da bacia do Recôncavo. São José dos Campos, 109 p. (Dissertação - Mestrado) - Instituto Nacional de Pesquisas Espacias.

BETTENCOURT, J.S. ; WERNICK, E. ; PENALVA, F. (1976) Contribuição à metalogenia do Sistema de Dobramentos Ribeira. In: CONGRESSO BRASILEIRO DE GEOLOGIA, 29., Ouro Preto, 1976. Anais. Ouro Preto, SBG, v. 1, p. $169-180$.

BIGARELLA, J.J. ; SALMUNI, R. (1956a) Estudos preliminares na série Açungui $V$ - Estruturas organógenas nos dolomitos da Formação Capiru (Estado do Paraná). Dusenia, v. 7, n. 6, p. 317-323.

BIGARELLA, J.J. ; SALAMUNI, R. (1956b) Estudos preliminares na série Açungui VII - Algumas estruturas singenéticas nos dolomitos da Formação Capiru. Arq. Biol. Tecnol., IBPT, Curitiba, 11:197-205.

BIGARELLA, J.J. ; SALAMUNI, R. (1958a) Contribuição à geologia da região sul da série Açungui, Estado do Paraná. Boletim Paulista de Geografia, v. 29, p. $1-14$.

BIGARELLA, J.J. ; SALAMUNI, R. (1958b) Estudos preliminares na série Açungui VIII - A Formação Votuverava. Boletim Geologia. Instituto de História Natural, n. 2, p.1-6.

BIONDI, J.C. (1983) Mapa geológico da área do embasamento do Estado do Paraná. Curitiba, Mineropar, Secretaria da Indústria e Comércio do Paraná. (escala 1:250.000).

BONHAM-CARTER, G.F. (1994) Geographic Information Systems for Geoscientists, Ottawa, Pergamon, 397p.

BRAGHIN, M.A. (1998) Utilização das lógicas Booleana e Fuzzy para análise metalogenética na folha Pilar do Sul (SP) via sistema de informações 
geográficas. Campinas, 112 p. (Dissertação - Mestrado) - Instituto de Geociências, Universidade de Campinas.

BURROUGHS, P.A. (1987) Principles of Geographical Information Systems for Land Resource Assessment. Oxford, Clarendon Press, 193 p.

CAMPANHA, G.A.C. ; GIMENEZ FILHO, A. ; CAETANO, S.L.V.; PIRES, F.A. ; DANTAS, A.S.L. ; TEIXEIRA, A.L. ; DEHIRA, L.K. (1986) Geologia e estratigrafia da região das folhas Iporanga e Gruta do Diabo, Vale do Ribeira, São Paulo. In: CONGRESSO BRASILEIRO de GEOLOGIA, 34, Goiânia, 1986. Anais. Goiânia, SBG, v. 2, p.1058-1073.

CAMPANHA, G.A.C. ; BISTRICHI, C.A. ; ALMEIDA, F.M.A. de (1987) Considerações sobre a organização litoestratigráfica e evolução tectônica da Faixa de Dobramentos Apiaí. In: SIMPÓSIO SUL-BRASILEIRO de GEOLOGIA, 3, Curitiba, 1987. Atas. SBG, v. 2, p. 725-742.

CAMPANHA, G.A.C. (1991) Tectônica proterozóica no Alto e Médio Vale do Ribeira, Estados de São Paulo e Paraná. São Paulo, 296p. (Tese - Doutorado) - Instituto de Geociências, Universidade de São Paulo.

CAMPANHA, G. A. C. ; GIMENEZ FILHO, A. ; BISTRICHI, C.A. (1995) Geologia da Folha Itararé em 1:250 000. In: SIMPÓSIO DE GEOLOGIA DO SUDESTE, 4, Águas de São Pedro, 1995. Boletim. Águas de São Pedro, _SBG, p. 111.

CAMPANHA, G.A.C. ; GIMENEZ FILHO, A. ; BISTRICHI, C.A. (1996) Geologia da Folha Itararé. São Paulo, IPT, inédito, 31p. (Minuta de Relatório)

CAMPANHA, G.A.C. ; SADOWSKI, G.R. (1998) Tectonics of southern portion of the Ribeira Belt (Apiai Domain), Journal of African Earth Sciences, Special Abstracts issue, v. 27, n. 1A, p. 220-221. 
CASSEDANE, J. (1972) Catalogue descriptif des gites de plomb et zinc du Brésil. 336p. (Tese - Doutorado) - Universite de Clermont.

CHIODI FILHO,C. ; ALEGRI, V. ; BATOLLA F. ; FERREIRA, J.C.G. (1982) Geologia e mineralizações da região que abrange as minas do Rocha, Paqueiro e Barrinha, Vale do Ribeira, PR e SP. In: CONGRESSO BRASILEIRO DE GEOLOGIA, 32, Salvador, 1982. Anais. Salvador, SBG, v. 3, p. 1037-1048.

COX, D.P. ; SINGER, D.A. (1986) Mineral deposit models. USGS Bulletin, $n$. 1693, p.1-391.

CPRM-ENCAL (1979) Projeto Aerogeofísico São Paulo-Rio de Janeiro Levantamento Aeromagnetométrico e Aerogamaespectrométrico. Relatório Final Sub-áreas II e IV, Encal S/A, 48p.

CPRM-GEOFOTO (1978) Projeto Serra do Mar Sul - Compilação de Dados do Levantamento Aeromagnetométrico na região da Serra do Mar nos Estados de Santa Catarina e Paraná. Relatório Final, Geofoto Ltda, 48p.

CPRM-Microsiga (1994) Sistema de Informações Geológicas do Brasil. Rio de Janeiro, CPRM. (CD-ROM)

CPRM-BARMP (1997) Brazil Airborne Radiometric Mapping Project. Technical Report and Survey Atlas. CPRM, Rio de Janeiro.

CREPANI, E. (1987) Análise de fraturas através de imagens fotográficas de baixa resolucão espacial: uma contribuição ao estudo da evolução tectônica da região da chapada do Araripe - NE do Brasil. São Paulo, 139 p. (Tese Doutorado) - Instituto de Geociências, Universidade de São Paulo.

DAITX, E.C. ; MORESCHI, J.B. ; BETTENCOURT, J.S. ; RUBERTI, E. ; BELLO, R.M.S. ; FERRER, L.M. (1995) Gênese da jazida de Furnas: estabelecimento de um modelo genético para depósitos filonares de $\mathrm{Pb}(\mathrm{Zn}, \mathrm{Ag})$ em rochas 
carbonatadas do Vale do Ribeira, Estado de São Paulo. Relatório Final de Projeto de Pesquisa, 148 p. (Processo Fapesp 91/2842-8)

DAITX, E.C. (1996) Origem e evolução dos depósitos sulfetados tipo Perau (Pb$\mathrm{Zn}-\mathrm{Ag}$ ), com base nas jazidas de Canoas e Perau (Vale do Ribeira, PR). Rio Claro, 453 p. (Tese - Doutorado) - Instituto de Geociências e Ciências Exatas, Universidade Estadual Paulista.

DAITX, E.C. (1997) Análise metalogenética das mineralizações de metais básicos e preciosos na região do Vale do Ribeira, estados do Paraná e São Paulo. Relatório Trienal - maio/1994 a maio/1997, Departamento de Petrologia e Metalogenia, Instituto de Geociências e Ciências Exatas, Rio Claro, UNESP, $103 p$.

DAMASCENO, E.C. (1967) Geologia da mina do Paqueiro. São Paulo, 69 p. (Tese - Doutorado) - Faculdade de Filosofia Ciências e Letras, Universidade de São Paulo.

DAMASCENO, E.C. (1970) Geologia da Mina do Paqueiro. Anais da Academia Brasileira de Ciências, v. 42, n. 3, p. 535-553.

DUDA, R.O. ; HART, P.E. ; NILSSOM, N.J. ; SUTHERLAND, G.L. (1978) Semantic network representations in rule-based interferenc systems. In: WATERMAN, D.A.; HAYES-ROTH, F. (eds) Pattern-Directed Inference Systems, Academic Press, p. 203-221.

EASTMAN, J.R. ; JIN, W. ; KYEM, A.K. ; TOLEDANO, J. (1995) Raster Procedures for Multi-Criteria/Multi-Objective Decisions. Photogrammetric Engineering \& Remote Sensing, v. 61, n. 5, p. 539-547.

EASTMAN, J.R. (1997) Idrisi for Windows, User's Guide, version 2.0. Clark Labs for Cartographic Technology and Geographic Analysis, Clark University, Worcester. 
ESRI (1995) Performing Analysis with GRID - Suitability Modeling and Hydrologic Analysis. In: WORKSHOP OF THE ESRI USER CONFERENCE, Proceedings v. 1, p. $372-382$.

EVANS, A.M. (1992) Ore geology and industrial minerals, an introduction. Oxford, Blackwell, 389 p. (Geoscience texts)

FIGUEIREDO, B.R. (coordenador) (1988) Implantação do índice de depósitos minerais do estado de São Paulo - IDEM/SP (Contrato UNICAMP/FUNCAMP - 479/87 e Pró-Minério/SCT - 1032/86), Relatório técnico final, 51 p., São Paulo, Unicamp (disquetes).

FINLOW-BATES, T. (1980) The chemical and physical control on the genesis of submarine exhalative orebodies and their implications for formulating exploration concepts. A review. Geologisches Jarbuch, Serie D, n.40, p.131168.

FLEISCHER, R. (1976) A pesquisa de chumbo no Brasil. In: CONGRESSO BRASILEIRO DE GEOLOGIA, 29, Ouro Preto, 1976. Anais. Ouro Preto, SBG, v. 1, p. 19-32.

FOJT, B. (1966) Keratophyre rocks of the kies deposits in the Jeseniky area. In: Fediuk, F. ; Fisera, M. (eds) Paleovulcanites of the Bohemian Massif. PFF UK, Praha, p. 107-114.

FRITZONS Jr, O. ; PIERKARZ, G.F. ; FALCADE, D. (1982) Geologia e potencial econômico do Grupo Setuva (PR). In: CONGRESSO BRASILEIRO DE GEOLOGIA, 32, Salvador, 1982. Anais. Salvador, SBG, v. 3, p. $987-1001$.

GEOFREY, D.R. ; SANTOS, T.D. (1942) Nota sobre a geologia de Apiaí. Mineração \& Metalurgia, v. 6, n. 33, p. 109-110. 
GNOJEK, I. ; PRICHYSTAL, A.A. (1985) New zinc mineralization detected by airborne gamma-ray spectrometry in Northern Moravia (Czechoslovakia). Geoexploration, v. 23, p. 491-502.

GOODFELLOW, W.D. ; LYDON, J.W. ; TURNER, R.J.W. (1993) Geology and Genesis of Stratiform Sediment - hosted (sedex) Zinc-Lead-Silver Sulphide Deposits. In: KIRKHAM, R.V. ; SINCLAIR, W.D. ; THORPE, R.I. ; DUKE, J.M. (EDS) Mineral Deposit Modeling, Toronto, G.A.C., p. 201-251. (Geological Association of Canada, Special Paper ,40)

GUIMARÃES FILHO, H.A. (1994) Metodologias para intercâmbio de dados entre programas de CADD, SGBD, PDI e SGI em projetos de exploracão mineral. Campinas, 118 p. (Dissertação - Mestrado) - Instituto de Geociências, Universidade de Campinas.

GUNN, P. ; MAIDMENT, D. ; MILLIGAN, P.R. (1997) Interpreting aeromagnetic data in areas of limited outcrop. AGSO Journal of Australian Geology \& Geophysics, v. 17, n. 2, p. 175-185.

HAMA, M. ; ALGARTE, J.P. (1986) Projeto Mapas Metalogenéticos e de Previsão de Recursos Minerais, 1:250.000 - Folha ltararé - SG.22-X-B. São Paulo, CPRM, 2 v.

HASUI,Y. ; SADOWSKI, G.R. (1976) Evolução geológica do Pré-Cambriano na região sudeste do Estado de São Paulo. Revista Brasileira de Geociências, v. 6, n. 3, p. $182-200$.

HASUI, Y. ; OLIVEIRA, M.A.F. (1984) Provincia Mantiqueira, Setor Central. In: ALMEIDA, F.F.M. de ; HASUI, Y. (eds) O Pré-Cambriano do Brasil. São Paulo, Edgar Blücher, p.308-344.

HASUI, Y. ; COPPEDE, A.J. ; CAETANO, A.C. ; SANCHEZ, L.H. (1992) Aspectos geológicos-estruturais na área da mina de Furnas (Municipio de Iporanga, SP) 
e o problema de fluxo de efluentes. In: HASUI, Y. ; MIOTO, J.A. (eds) Geologia Estrutural Aplicada - Estudo de casos. São Paulo, IPT, p. 399-410.

IBGE (1990a) Mapa Magnético do Brasil - elemento intensidade total. Rio de Janeiro, IBGE/Diretoria de Geociências/Observatório Nacional. (Escala 1:10.000.000).

IBGE (1990b) Mapa Magnético do Brasil - elemento declinação. Rio de Janeiro, IBGE/Diretoria de Geociências/Observatório Nacional. (Escala 1:10.000.000).

JENSEN, M.L. ; BATEMAN, M. (1981) Economic Mineral Deposits. New York, John Wiley \& Sons, $593 \mathrm{p}$.

KATZ, S.Z. (1991) Emulating Expert System with Raster GIS. Computers \& Geoscience, v. 17, p. 1033-1050.

KNECHT, T. (1938) Jazidas de minério de chumbo - Contribuição à gênese de algumas jazidas de minério de chumbo nos municípios de Apiaí e Capão Bonito, São Paulo. Mineração e Metalurgia, v. 3, n. 13, p. 41-43.

KEEFER, B.J. ; SMITH, J.L. ; GREGOIRE, T.G. (1991) Modeling and Evaluating the effects of stream mode digitizing errors on map variables. Protogrammetric Enginnering \& Remote Sensing, v. 557, n. 7, p. 957-963.

LARGE, D.E. (1980) Geological parameters associated with sediment hosted, submarine exhalative $\mathrm{Pb}-\mathrm{Zn}$ deposits: An empirical model for mineral exploration. Geologisches Jahrbuch, Serie D, v. 40, p. 59-129.

LARGE, D.E. (1983) Sediment-hosted massive sulphide lead-zinc deposits: An empirical model. In: SANGSTER, D.F. (ed) Sediment-hosted stratiform leadzinc deposits. Toronto, Mineralogical association of Canada, p. 1-29. (Short Course Handbook, n.9) 
LEONARDOS, O. (1934) Chumbo e Prata no Brasil. Boletim Serviço de Fomento Produção Mineral, 2, p. 111.

LICHT, O.A.B ; TARVAINEN, T. (1996) Multipurpose geochemical maps produced by integration of geochemical exploration datasets in the Paraná Shield, Brazil. Journal of Geochemical Exploration, v. 56, p. 167-182.

LOPES, O.F. (1983) Faixa Perau: Uma unidade faciológica e tectono-metamórfica do Grupo Açungui. Revista Brasileira de Geociências, São Paulo, v. 13, n. 3 , p. 190-203.

LYDON, J.W. (1990) Volcanogenic Massive Sulphide Deposits. In: ROBERTS, R.G. ; SHEAHAN, P.A. (eds) Ore Deposit Models. Geoscience Canada, reprint series 3, Geological Association of Canada, 194p.

MACEDO, A.B. ; ADDAS, W. ; BATOLLA JÚNIOR, F. (1981) Metodologia de prospecção geoquímica em Minas do Vale do Ribeira (PR). In: SIMPÓSIO REGIONAL DE GEOLOGIA, 3, Curitiba, 1981. Atas. Curitiba, SBG, v. 1, p. 71 $-81$.

MACEDO, A.B. (1986) Prospeccão litogeoquímica na mina do Perau, Paraná. São Paulo, 162 p. (Tese - Doutorado) - Instituto de Geociências, Universidade de São Paulo.

MACEDO, A.B. (1996) Reflexões sobre tratamentos de dados geoquímicos. São Paulo, 151 p. (Tese - Livre Docência) - Instituto de Geociências, Universidade de São Paulo.

MAGUIRE, D.J., DANGERMOND, J. 1993, The funcionality of GIS. In: Maguire, D.J., Goodchild, M.F., Rhind, D.W., Geographical Information Systems: Principles and Applications. New York, Longman, 1991, p/319 - 336. 
MAIDMENT, R.D., (1998) Watershed, stream network, and drainage area delineation in grid, disponivel na internet: http://www.ce.utexas.edu/prof/maidment/gishydro/docs/am/s/wtrshd.htm.

MARES, S. (1984) Introduction to applied geophysics. Dordrecht, D.Reidel Publishing Company, $581 \mathrm{p}$.

MARINI, O.J.; TREIN, E.; FUCK, R.A. (1967) O Grupo Açungui no Estado do Paraná. Boletim Paranaense de Geociências, v.23, n. 25, p. 43-104.

MELCHER, G.C. ; JOHNSON, R.F. (1956) Geologia e depósitos de Chumbo do Vale do Ribeira de Iguape. DNPM/DFPM, Rio de Janeiro, 68 p. (inédito).

MELCHER, G.C. (1968) Contribuição ao Conhecimento do Distrito Mineral do Ribeira de Iguape, Estados de São Paulo e Paraná. São Paulo, 122 p. (Tese - Livre Docência) - Escola Politécnica da Universidade de São Paulo.

MELLO, I.S.C. (1995) Geologia e estudo metalogenético do Maciço Itaoca, Vale do Ribeira, SP e PR. São Paulo, 168 p. (Tese - Doutorado) - Instituto de Geociências, Universidade de São Paulo.

MMAJ-JICA (1981) Report on geological survey of Anta Gorda - Brazil - phase 1. Convênio DNPM/JICA/MMAJ, Tokyo, 79p.

MMAJ-JICA (1982) Report on geological survey of Anta Gorda - Brazil - phase 2. Convênio DNPM/JICA/MMAJ, Tokyo, 119 p.

MMAJ-JICA (1983) Report on geological survey of Anta Gorda - Brazil - phase 3. Convênio DNPM/JICA/MMAJ, Tokyo, 111p.

MMAJ-JICA (1984) Report on geological survey of Anta Gorda - Brazil - phase 3. Convênio DNPM/JICA/MMAJ, Tokyo, 57p. 
MORGENTAL, A.; BATOLLA JÚNIOR, F.; PINTO, G.G.; PAIVA, I.P.; DRUMOND, J.B.V. (1975) Projeto Sudelpa: fichas de ocorrências. São Paulo: Sudelpa/CPRM, 1975, 18v.

MORGENTAL, A.; SILVA, A.A.G.P. da; BORIN JÚNIOR, T.; ALEGRI, V.; OLIVEIRA, P. E.P. de. (1978) Projeto Geoquímica no Vale do Ribeira: relatório final. São Paulo, DNPM/CPRM. 8 v. (escala 1:100.000)

NICKELSEN, R.P. (1974) Early jointing and cumulative fracture patterns. In: INTERNATIONAL CONFERENCE ONT THE NEW BASEMENT TECTONIC, 1., Proceedings. Utah Geological Association Publication, n. 5, p. 193-199.

NORTHFLEET, A.A. ; BETTINI,C. ; CHAVES, H.A.F. (1971) Aplicação de geomatemática à prospecção de petróleo, análise de fraturas por poliedros ortogonais. In: CONGRESSO BRASILEIRO DE GEOLOGIA, 25, São Paulo, 1971. Anais. São Paulo, SBG, v. 3, p. 61 - 70.

ODAN, Y. ; FLEISCHER, R. ; ESPOURTEILLE, F. (1978) Geologia da Mina de Chumbo de Panelas - Adrianópolis - PR. In: CONGRESSO BRASILEIRO DE GEOLOGIA, 30, Recife, 1978. Anais. Recife, SBG, v. 4, p. 1545-1552.

OLIVEIRA, E.P. (1937) A jazida de galena argentífera das Panelas de Brejaúvas, Bocayuva - Paraná. Mineração e Metalurgia, v. 1, n. 5, p. 182.

OSTROVSKY, E.Y. (1973) Antagonism of radioactive elements in wallrock alterations fields and its use in aerogammaspectrometric prospecting. International Geology Review, v. 17, n. 2. p. 461-468.

PERROTA, M.M. (1996) Potencial aurifero de uma região no Vale do Ribeira, São Paulo, estimado por modelagem de dados geológicos, geoquímicos, geofísicos e de sensores remotos num sistema de informações geográficas. São Paulo, 149 p. (Tese - Doutorado) - Instituto de Geociências, Universidade de São Paulo. 
PETTINATI, F. (1983) Modelamento Digital e representação gráfica de superfícies. São Paulo, (Dissertação de Mestrado) - Escola Politécnica, Universidade de São Paulo.

PETRI, S. ; SUGUIO, K. (1969) Sobre os metassedimentos do extremo sul do Estado de São Paulo. São Paulo, convênio USP/DAEE (Publicação especial).

PIRAJNO, F.B. (1992) Hydrothermal mineral deposits: principles and fundamental concepts for the exploration geologist. Berlin, Springer, 709p.

PIERKARZ, G.F. (1981) Reconhecimento de unidades correlacionáveis à seqüência mineralizada do Perau, Estado do Paraná. In: SIMPÓSIO REGIONAL DE GEOLOGIA, 3, Curitiba, 1981. Atas. Curitiba,SBG, 417 p.

PLICKA, (1974) Observations on joint zones in Moravia, Czechoslovakia. New basement tectonics contribution, v. 30, p. 279-289.

RAMSAY, J.G. ; HUBER, M.I. (1987) The techniques of modern structural geology:- folds and fractures. v. 2 United Kingdom, Academic Press, 700 p.

RODRIGUES, M. (1990) Geoprocessamento. In: SIMPÓSIO BRASILEIRO DE GEOPROCESSAMENTO, 1, São Paulo, 1990, EPUSP, p. 1-27.

ROSTIROLLA, S.P. (1997) Alguns aspectos da avaliação de favorabilidade em geologia exploratória. Revista Brasileira de Geociências, v. 27, n. 4, p. 327 338.

ROSTIROLLA, S.P. ; Soares, P.C. ; Chang, H.K. (1998) Bayesian and Multivariate Methods applied to favorability quantification in Recôncavo Basin and Ribeira Belt, Brazil. Nonrenewable Resources, v. 7, n. 1, p. 7-24. 
SAWKINS, F.J. (1976) Massive sulfide deposits in relation to geotectonics. Geological Association Canadian. Special Publication, v. 14, p. 221-240.

SANTOS, A.R. (1986) Estudos sobre a tectônica de fraturamento na região do quadrilátero ferrífero e em partes do complexo migmatito-granulítico de Minas Gerais, com base em sensoriamento remoto. São Paullo, 172 p. (Tese Doutorado) - Instituto de Geociências, Universidade de São Paulo.

SCHöLL, W.V. ; SILVA, A.C.G.A. ; MONASTIER, M.S. (1982) A Formação Setuva do Pré-Cambriano no Estado do Paraná; uma revisão crítica. In: CONGRESSO BRASILEIRO de GEOLOGIA, 32, Salvador, 1982. Anais. Salvador. SBG, v.1, p.55-63.

SILVA, R. B. ; MAEYAMA, O. ; PEROSA, P. T. ; ALMEIDA, E.B. ; SARAGIOTTO, J.A.R. (1982) Considerações sobre as mineralizações de chumbo, zinco e prata do Grupo Açungui no Estado de São Paulo. In: CONGRESSO BRASILEIRO DE GEOLOGIA, 32., Salvador, 1982. Anais. Salvador, SBG, v. 3, p. 972 - 986.

SILVA, C.R. ; TAKAHASHI, A.T. ; CHIODI FULHO, C. ; BATOLLA JR., F. (1982) Geologia e mineralizações na região do Perau - Água Clara, Vale do Ribeira, PR. In: CONGRESSO BRASILEIRO DE GEOLOGIA, 32., Salvador, 1982. Anais. Salvador, SBG, v. 3, p. 1024-1036.

SILVA, D.C. ; MANTOVANI, M.S.M. (1994) Projeto Aerogeofísico Serra do Mar Sul: uma abordagem semi-quantitativa. Revista Brasileira de Geociências, v. 24, n. 2, p.120-127.

SINCLAIR, A. J. (1974) Selection of Threshold Values in Geochemical data Using Probability Graphs. Journal of Geochemical Exploration, v. 3, p. 129-149.

SOARES, P.C. ; FIORI (1976) Lógica e sistemática na análise e interpretação de fotografias aéreas em geologia. Noticia Geomorfológica, v. 16, n. 32, p. 71-40. 
SOUZA, I.M.; CAMPANHA, G.A.C. (1977) Chumbo e cobre no Vale do Ribeira, mina Barra do Perau, municipio de Adrianópolis, estado do Paraná. Mineração e Metalurgia, v. 40, n. 384, p. 4-7.

STANLEY, C.R. (1987) An interactive computer program to fit mixtures of Normal (or log-Normal) Distributions with maximum likelihood optimization procedures - version 1.0. Association of Exploration Geochemists Canada, Special Volume 14, 40p.

TAKAHASHI, A.T. et al. (1981) Projeto integração e detalhe no Vale do Ribeira, área Ribeirão do Perau. São Paulo, convênio DNPM/CPRM.

TASSINARI, C.G.C. ; BARBOUR, A.P. ; DAITX, E.C. ; SATO, K. (1990) Aplicação dos isótopos de $\mathrm{Pb}$ e $\mathrm{Sr}$ ba determinação da natureza das fontes das mineralizações de chumbo do Vale do Ribeira - SP e PR. In: CONGRESSO BRASILEIRO DE GEOLOGIA, 36, Natal, 1990. Anais. Natal, SBG, v. 3, p. $1254-1266$.

WILLIAMS, X.K. (1967) Statistics in the Interpretation of Geochemical Data. New Zealand Journal of Geology and Geophysics, v. 10, p. 771-97.

VENEZIANI, P. (1987) Análise de movimentos da tectônica rúptil e rúptil-dúctil através da interpretacão de produtos de sensores remotos na região do espinhaço meridional (MG): Uma correlacão com processos evolutivos. São Paulo, 186 p. (Tese - Doutorado) - Instituto de Geociências, Universidade de São Paulo.

YAMAMOTO, J.K. (1986) Representações gráficas espaciais em geologia aplicações no complexo alcalino de Anitápolis. São Paulo, 167 p. (Dissertação - Mestrado) - Instituto de Geociências, Universidade de São Paulo. 


\title{
ANEXOS
}

\author{
Anexo I - AML Arclnfo \\ Anexo II - Mapa Geológico \\ Anexo III - Mapa de Ocorrências Minerais
}


Apresenta-se abaixo a AML executada no Arclnfo 7.1 para traçar automaticamente bacias de drenagem a montante de um ponto. Os dados de entrada consistem de um modelo numérico de terreno (tin) e de um arquivo vetorial (coverage) com os pontos de amostragem.

Este programa foi baseado em um exemplo de Maidment (1998) obtido na Internet: Center for Research in Water Resources - University of Texas at Austin / Examples of Hydrology AMLs for Arclnfo 7.0.

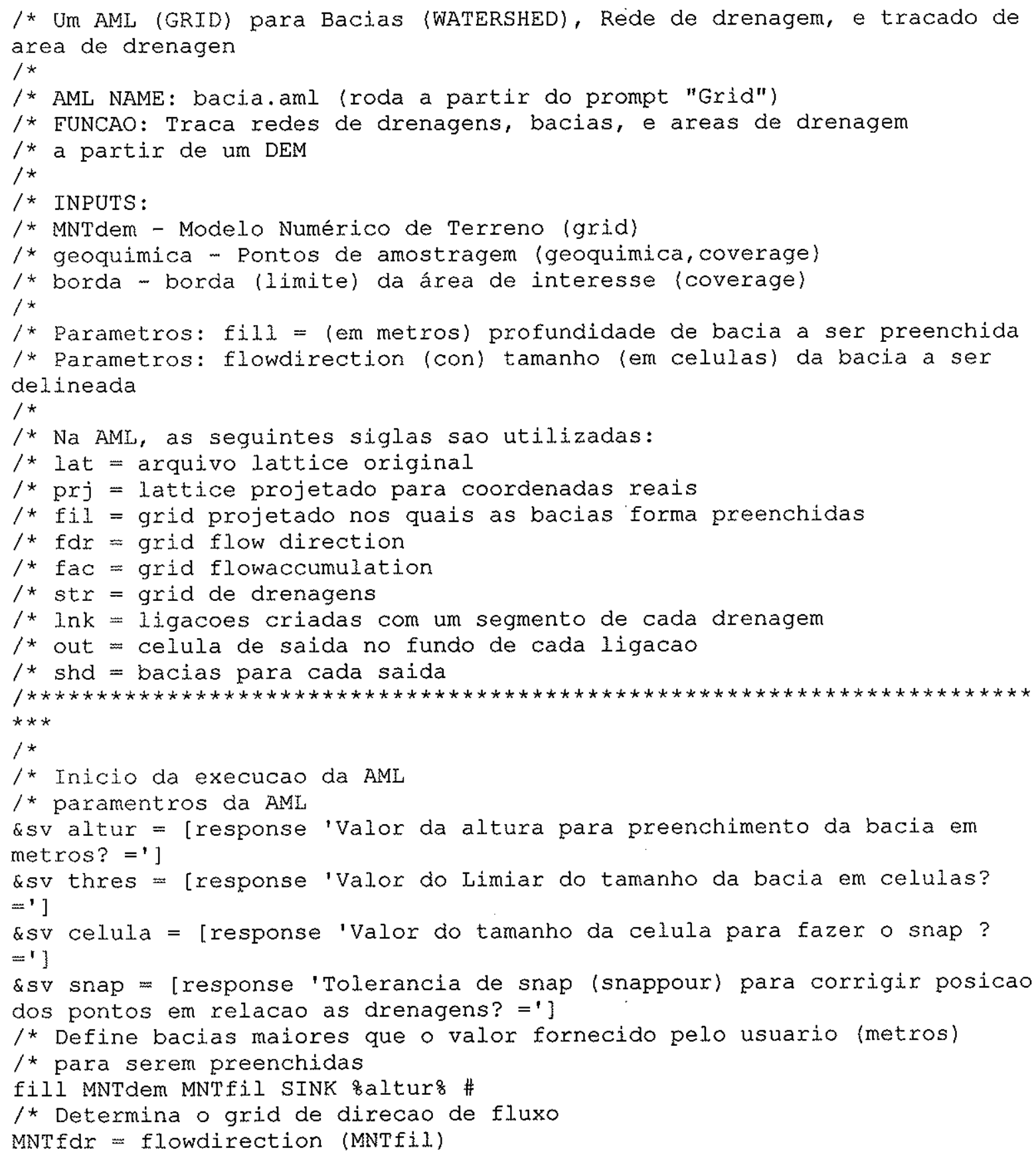


/* Calcula o grid de acumulacao de fluxo

MNTfac $=$ flowaccumulation $($ MNTfdr $)$

/* Pede ao usuario o limiar de celulas da acumulacao de fluxo que serao usados

1* para formar uma drenagem

/* isola as celulas que tem pelo menos o limiar da acumulacao de fluxo

MNTstr $=$ con $\left(\right.$ MNTfac $>\frac{\circ}{0}$ threso, 1 )

/* faz cada ligacao de drenagem unica

MNTlnk = streamlink (MNTstr, MNTfdr)

I* faz uma coverage a partir da ligacao de drenagens

covlnk = gridline (MNTlnk)

/* encontra ligacoes de saida

MNTacc $=$ zonalmax (MNTlnk, MNTfac)

MNTout $=\operatorname{con}($ MNTacc $==$ MNTfac, MNTlnk)

/* faz as bacias a partir destas saidas

MNTshd $=$ watershed (MNTfdr, MNTout)

/* faz uma coverage de poligonos das bacias

covshd $=$ gridpoly (MNTshd)

/* transforma a coverage em grid mantendo o identificador do usuario

pontosgrid = pointgrid (geoquimica, geoquimica-id, \#, \#, 部elula\%, nodata)

I* coloca todos os pontos na drenagem fazendo um snap a partir do valor definido pelo usuario

pontosnap = snappour (pontosgrid, mntfac, \%snap $\%$ )

/* transforma o grid em coverage mantendo o identificador do usuario

pontos = gridpoint (pontosnap, geoquimica-id)

/* volta ao prompt do Arc/Info

quit

I* cria uma coverage de pontos dos pontos de corrente "local" a partir da coveragem com projecao

clip pontos borda locpontos point

I* coloca coordenadas $\mathrm{x}$ e y aos pontos

addxy locpontos

I* chama O GRID

grid

/* define a localizacao dos pontos como sub-bacias "pontos de saida"

dentro das bacias

/* tracadas acima

ptsdrena $=$ selectpoint (MNTshd, locpontos)

I* **CUIDADO** Se a localizacao dos pontos de corrente nao cairem nas

drenagens

I* tracadas dentro do grid MNTshd, entao o grid ptsdrena grid pode ser gerado a

/* partir de um processo interativo atraves do uso de

selectpoint (MNTshd, *).

/* traca as areas de dreangem para cada ponto de corrente

shdareas $=$ watershed (mntfdr, ptsdrena)

/* cria uma coverage de poligono equivalente ao grid de areas de drenagem covareas $=$ gridpoly (shdareas)

\&return

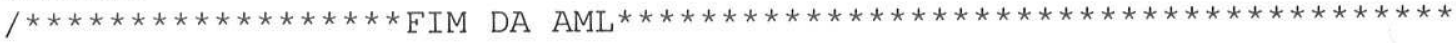



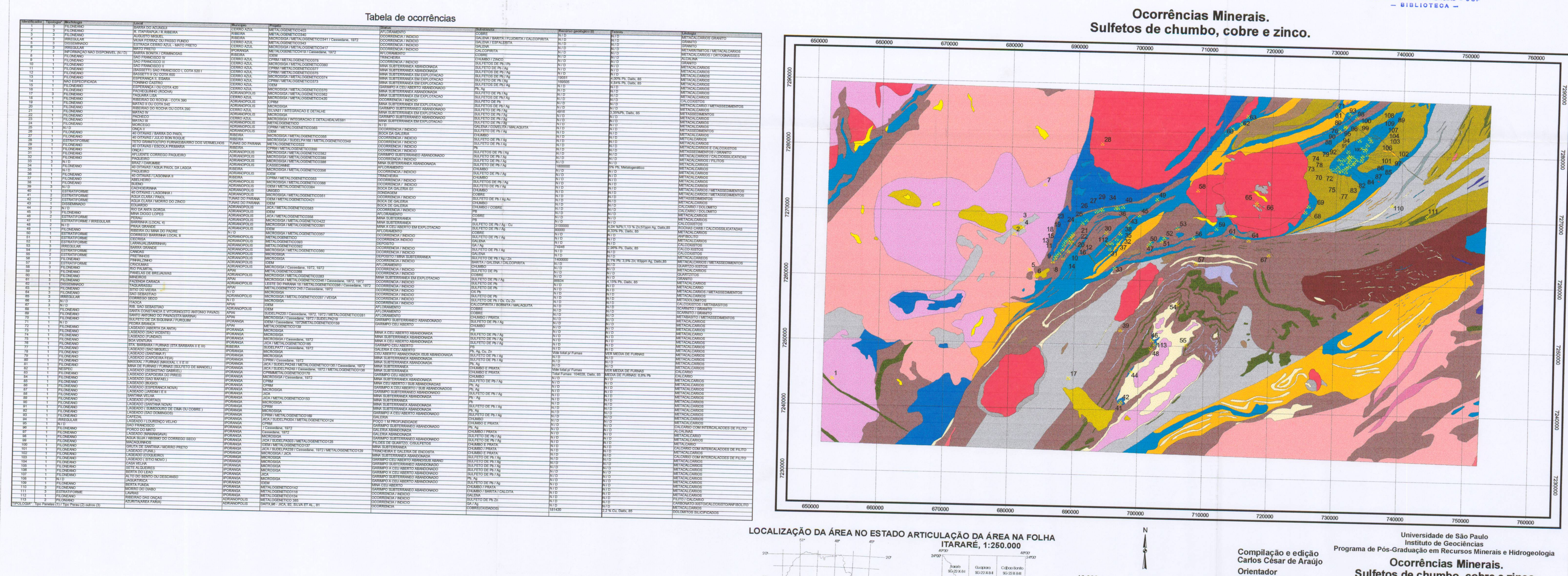

20 , . Sultosos se c chumbo, cobre arive

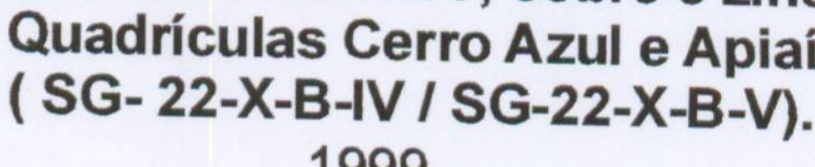


Mapa Geológico - Quadrículas Cerro Azul e Apiaí (SG-22-X-B-IV/ SG-22-X-B-V)

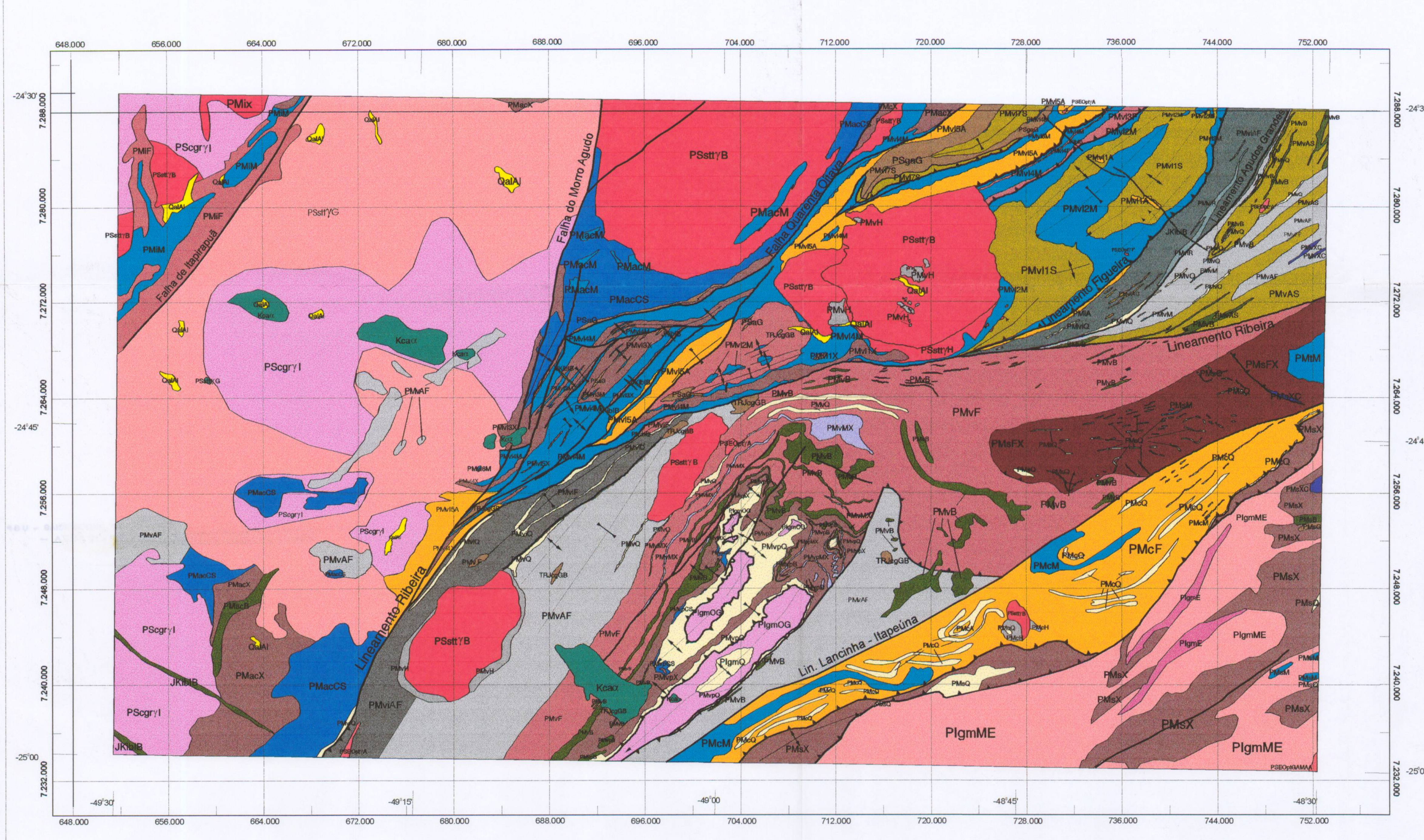

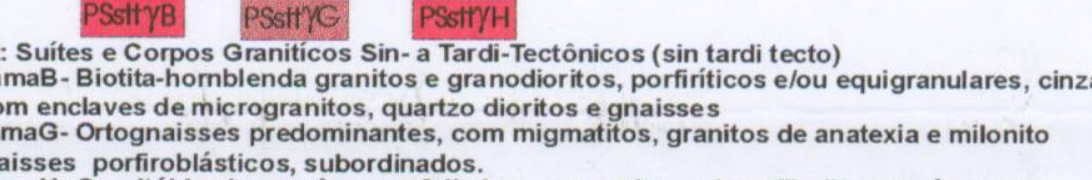

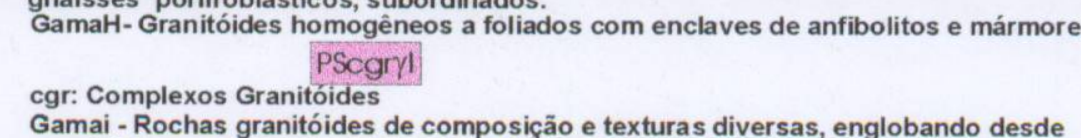

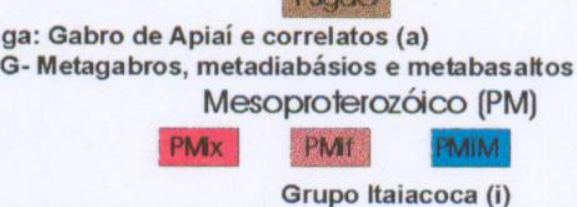

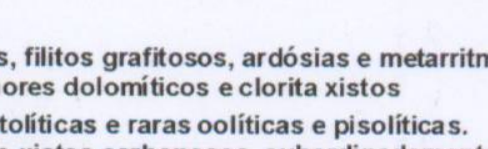

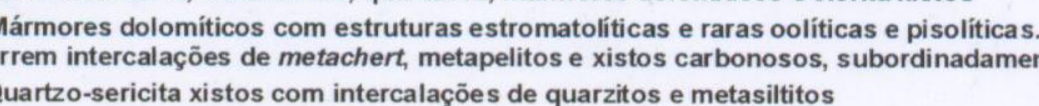

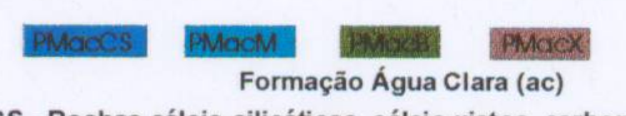

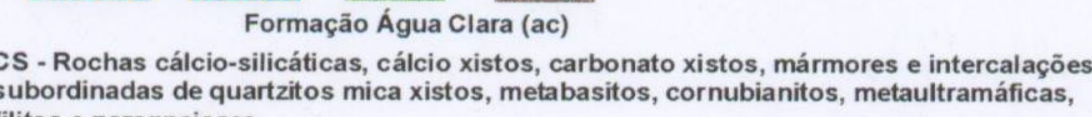

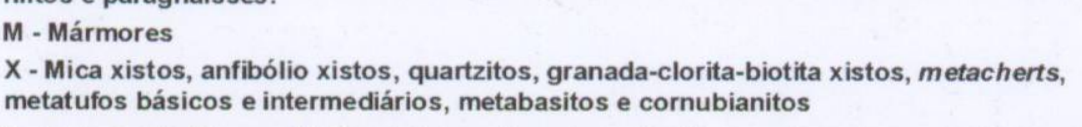

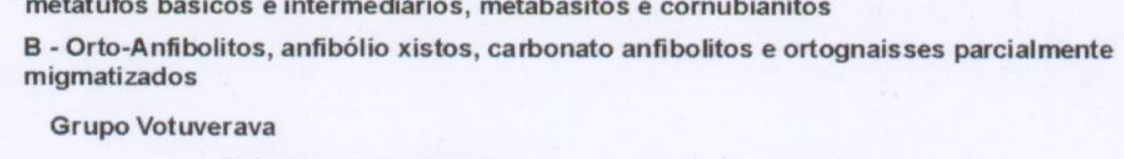

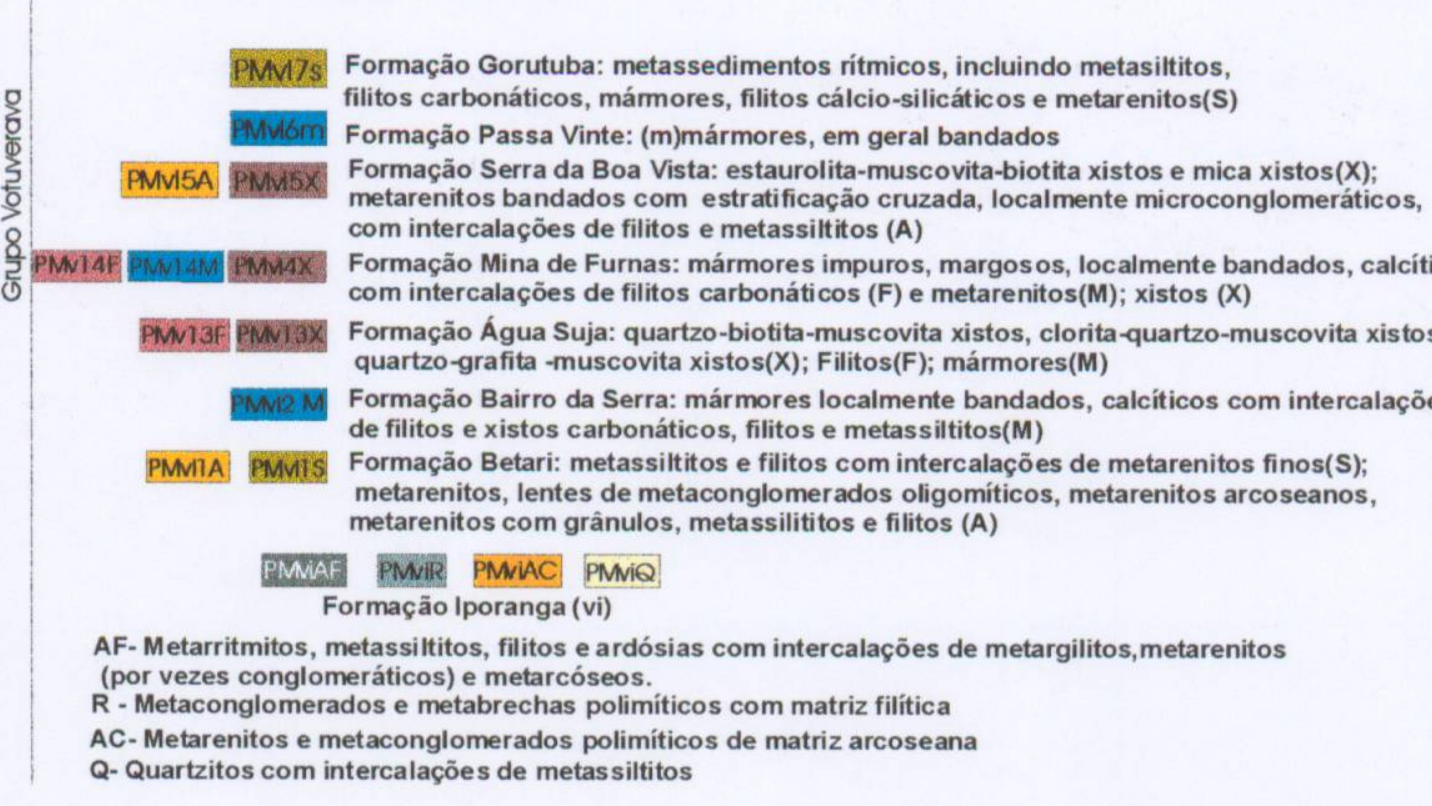

LOCALIZAĢão da ÁrEA No EsTAdo

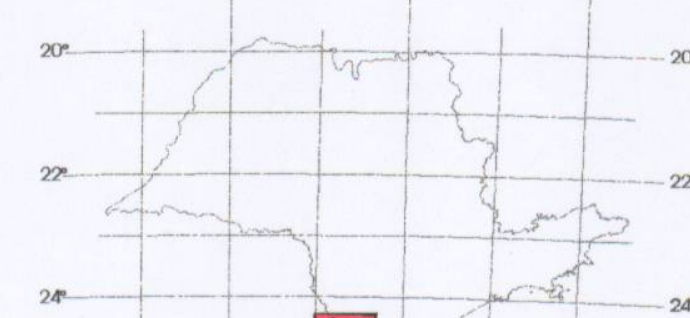

四

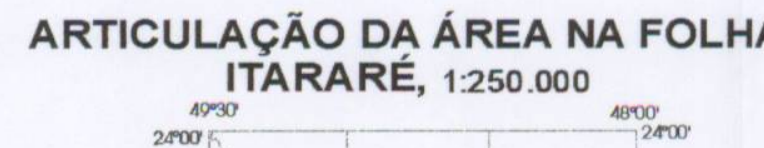

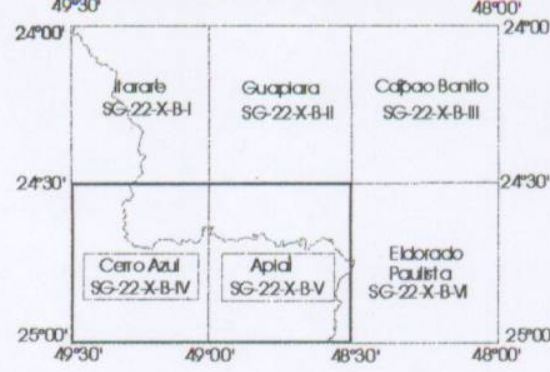

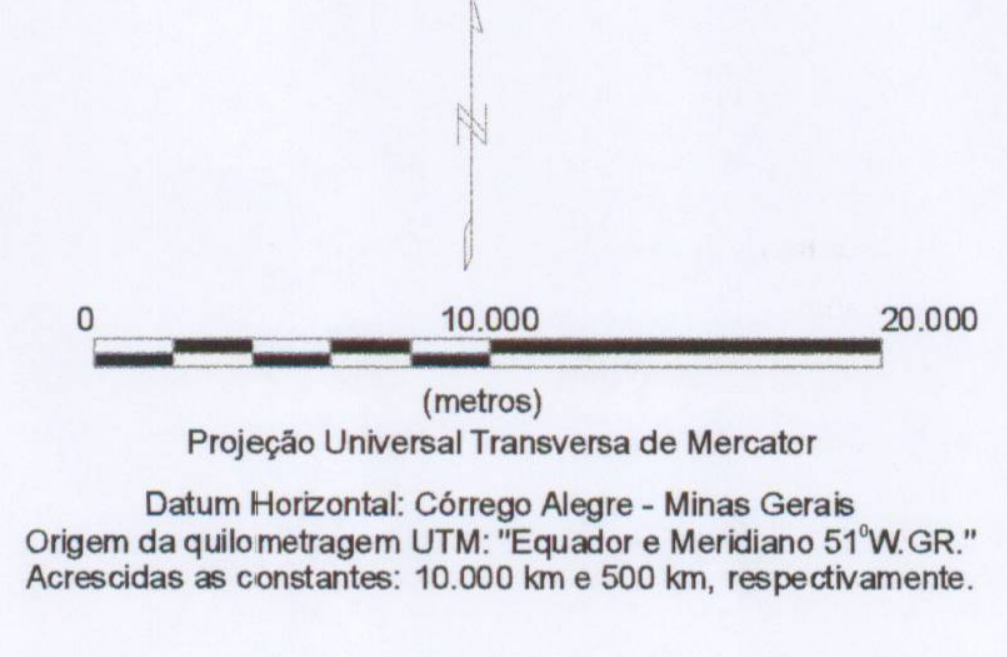

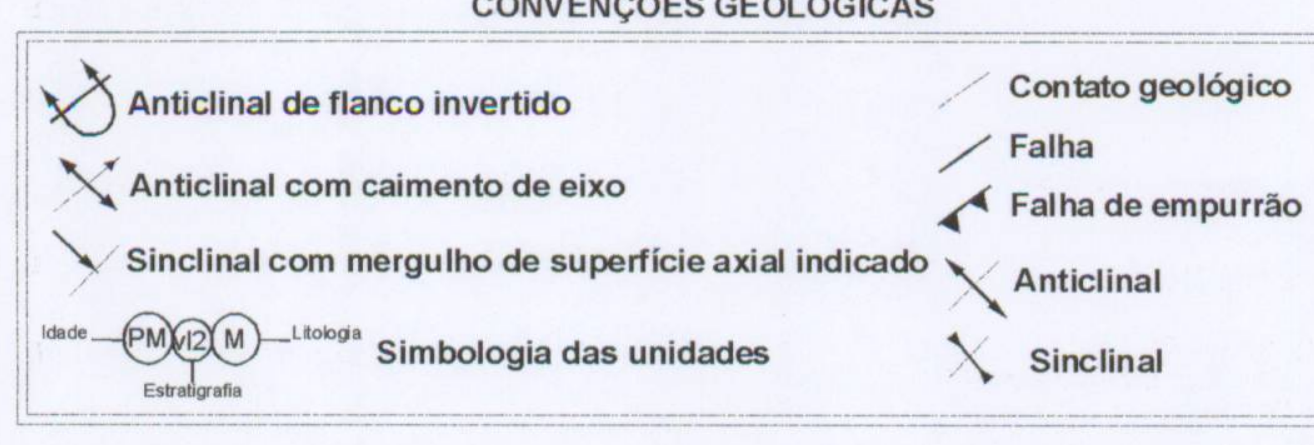

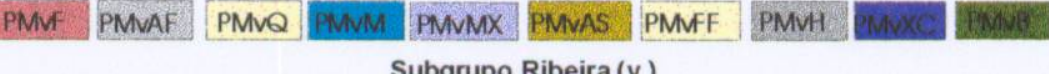

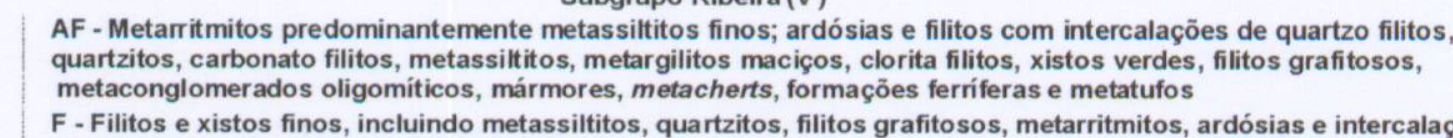

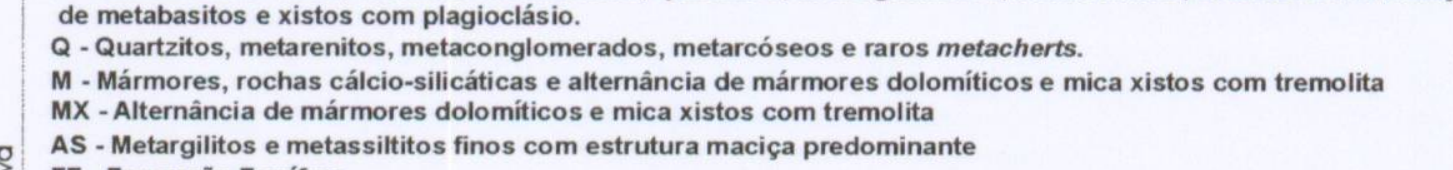

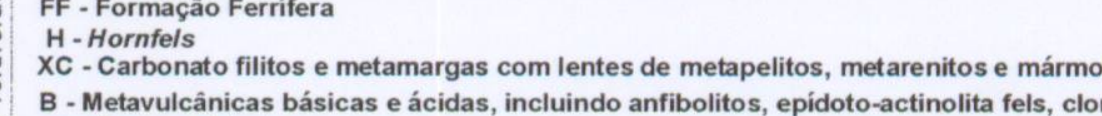

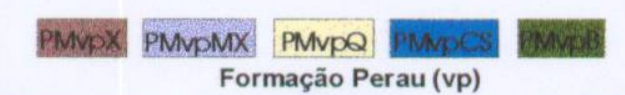

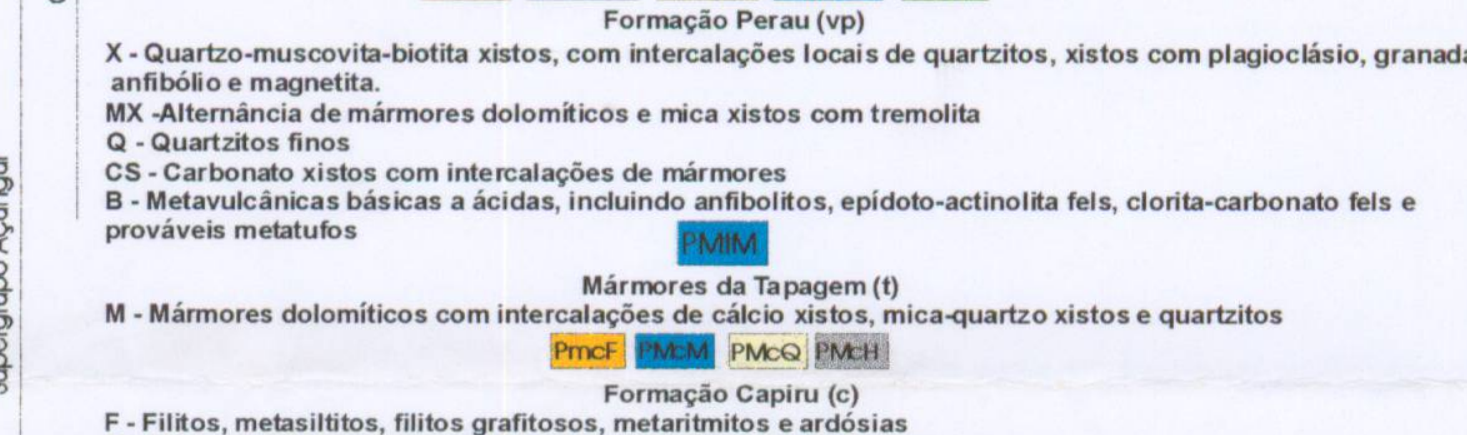

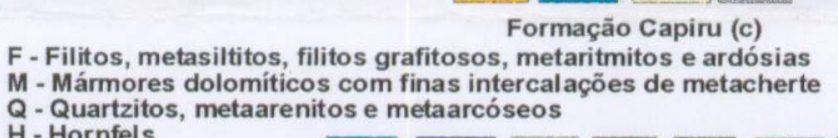

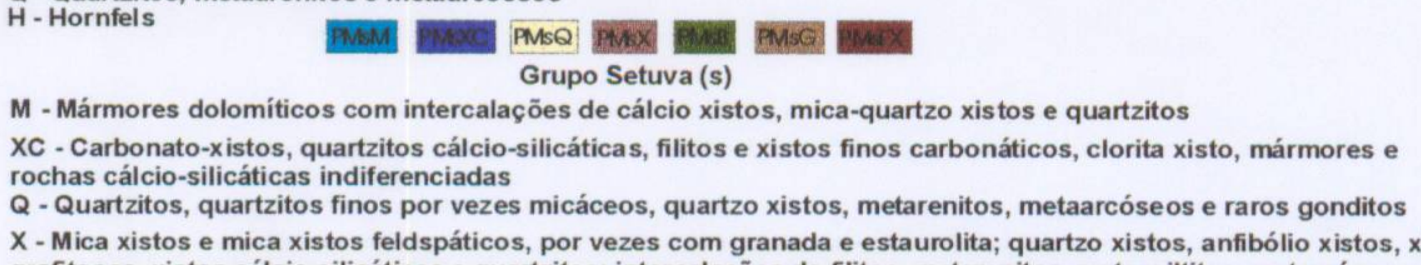

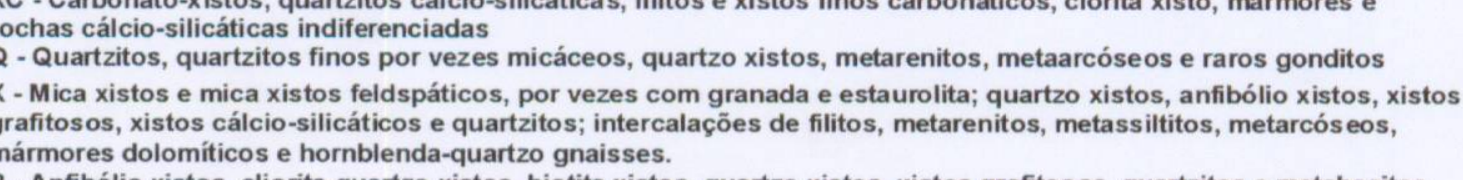

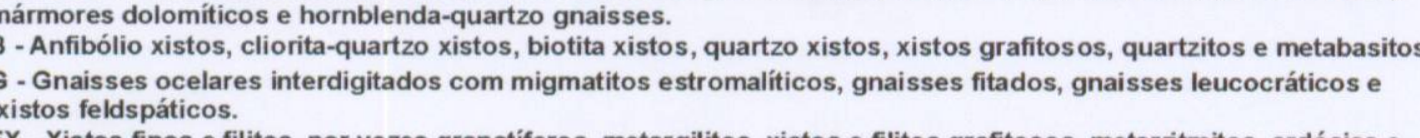

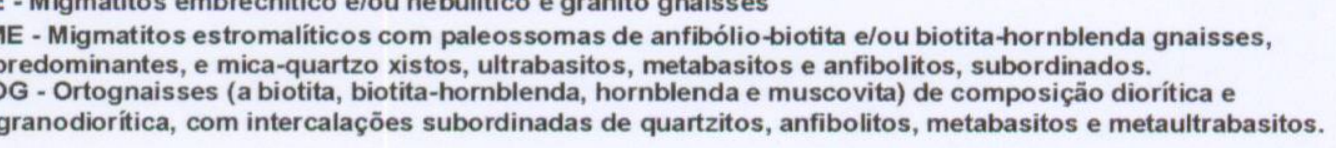

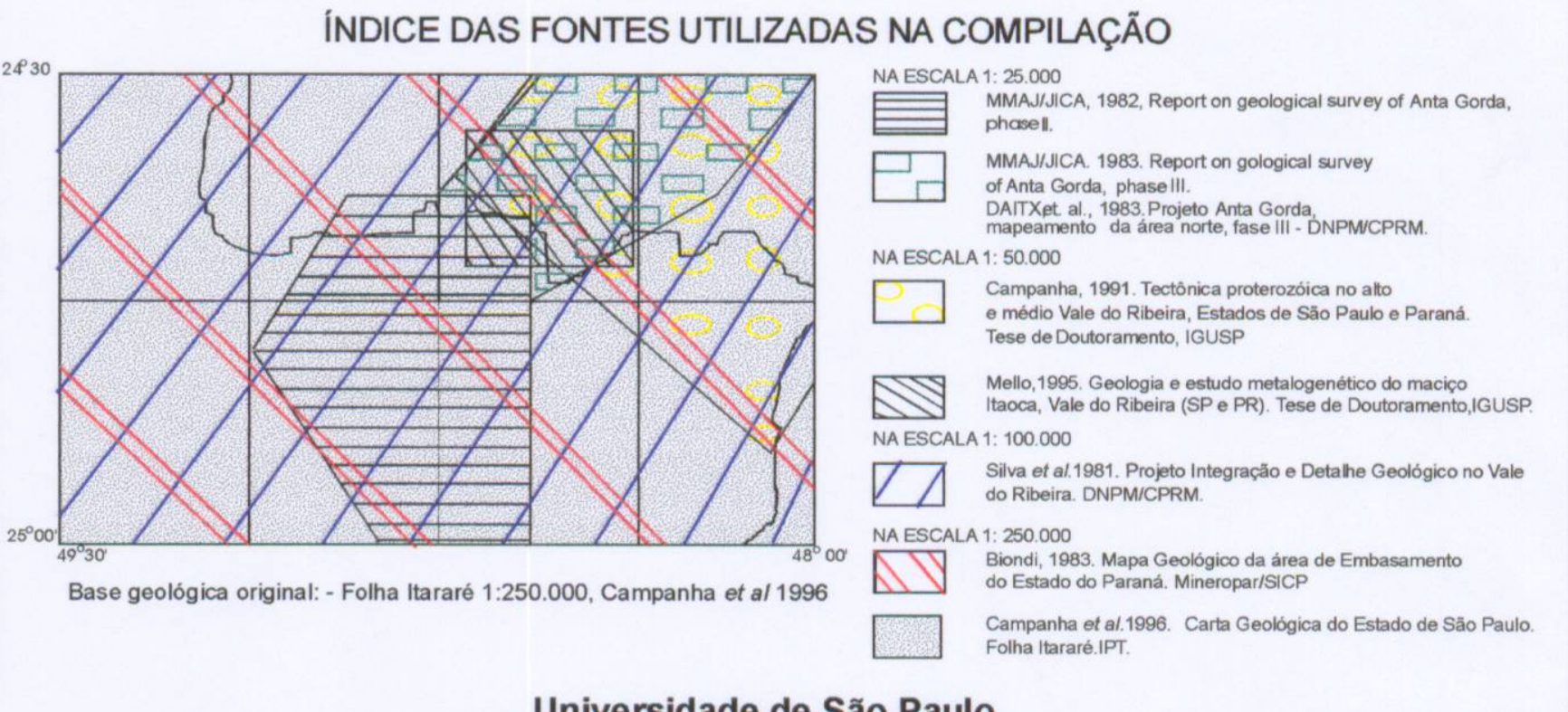

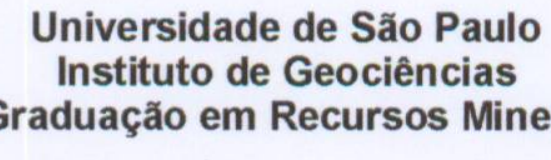
Azul e Apia ( SG- 22-X-B-IV/ SG-22-X-B-V) 1999 Apoio Fapesp
(processos 97/04664-0 e 97/04272-0)

Compilação e ediçáa o
Carlos Cesar de Arauijo e Ginaldo A. da C. Campanha

Orientador
Arlei Benendito Macedo

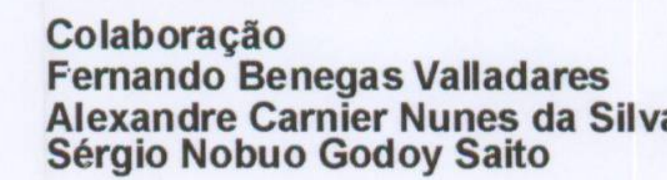

